\title{
Corporate Governance of State-Owned Enterprises
}

A TOOLKIT

(4) WORLD BANK GROUP 



\section{Corporate Governance of State-Owned Enterprises}





\section{Corporate Governance of State-Owned Enterprises}

A Toolkit 
(c) 2014 International Bank for Reconstruction and Development / The World Bank

1818 H Street NW, Washington, DC 20433

Telephone: 202-473-1000; Internet: www.worldbank.org

Some rights reserved

123417161514

This work is a product of the staff of The World Bank with external contributions. The findings, interpretations, and conclusions expressed in this work do not necessarily reflect the views of The World Bank, its Board of Executive Directors, or the governments they represent. The World Bank does not guarantee the accuracy of the data included in this work. The boundaries, colors, denominations, and other information shown on any map in this work do not imply any judgment on the part of The World Bank concerning the legal status of any territory or the endorsement or acceptance of such boundaries.

Nothing herein shall constitute or be considered to be a limitation upon or waiver of the privileges and immunities of The World Bank, all of which are specifically reserved.

\section{Rights and Permissions}

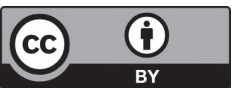

This work is available under the Creative Commons Attribution 3.0 IGO license (CC BY 3.0 IGO) http://creativecommons.org/licenses/by/3.0/igo. Under the Creative Commons Attribution license, you are free to copy, distribute, transmit, and adapt this work, including for commercial purposes, under the following conditions:

Attribution-Please cite the work as follows: World Bank. 2014. Corporate Governance of StateOwned Enterprises: A Toolkit. DOI: 10.1596/978-1-4648-0222-5. Washington, DC: World Bank. License: Creative Commons Attribution CC BY 3.0 IGO

Translations-If you create a translation of this work, please add the following disclaimer along with the attribution: This translation was not created by The World Bank and should not be considered an official World Bank translation. The World Bank shall not be liable for any content or error in this translation.

Adaptations-If you create an adaptation of this work, please add the following disclaimer along with the attribution: This is an adaptation of an original work by The World Bank. Responsibility for the views and opinions expressed in the adaptation rests solely with the author or authors of the adaptation and are not endorsed by The World Bank.

Third-party content-The World Bank does not necessarily own each component of the content contained within the work. The World Bank therefore does not warrant that the use of any thirdparty-owned individual component or part contained in the work will not infringe on the rights of those third parties. The risk of claims resulting from such infringement rests solely with you. If you wish to re-use a component of the work, it is your responsibility to determine whether permission is needed for that re-use and to obtain permission from the copyright owner. Examples of components can include, but are not limited to, tables, figures, or images.

All queries on rights and licenses should be addressed to the Publishing and Knowledge Division, The World Bank, 1818 H Street NW, Washington, DC 20433, USA; fax: 202-522-2625; e-mail: pubrights@ worldbank.org.

ISBN (paper): 978-1-4648-0222-5

ISBN (electronic): 978-1-4648-0229-4

DOI: $10.1596 / 978-1-4648-0222-5$

Cover design: Debra Naylor, Naylor Design, Inc.

\section{Library of Congress Cataloging-in-Publication Data}

Corporate governance of state-owned enterprises : A Toolkit / The World Bank. pages $\mathrm{cm}$

Includes bibliographical references and index.

ISBN 978-1-4648-0222-5 (alk. paper) - ISBN 978-1-4648-0229-4 (electronic : alk. paper)

1. Government business enterprises. 2. Government ownership. 3. Corporate governance. I. World Bank.

HD62.35.C67 2014

$352.2^{\prime} 66-\mathrm{dc} 23$ 


\section{CONTENTS}

Acknowledgments $\quad$ xi

Abbreviations xiii

Introduction to the Toolkit $\quad x v$

Executive Summary $\quad x x i$

1. Context and Overview 1

Past SOE Reforms

Role and Importance of SOEs 3

SOE Performance and Impacts 9

Corporate Governance Challenges in SOEs $\quad 12$

The Benefits of Good Corporate Governance 16

Framework for Corporate Governance Reform 18

2. Legal and Regulatory Framework 25

Key Concepts and Definitions 26

Overview of SOE Legal Forms and Frameworks 28

Key Issues in the SOE Legal Framework $\quad 31$

Harmonizing SOE Frameworks with Private Sector Frameworks 33

Developing a State Ownership Framework for SOEs 45

3. State Ownership Arrangements 69

Key Concepts and Definitions $\quad 70$

Overview of Ownership Arrangements 70

Improving Traditional Ownership Arrangements $\quad 71$

Creating Advisory or Coordinating Bodies $\quad 75$

Centralizing the State's Ownership Functions 78

Ensuring the Effectiveness of Ownership Arrangements 93 
4. Performance Monitoring

Key Concepts and Definitions

Objectives of a Performance-Monitoring System 102

Obtaining Baseline Information 104

Setting Mandates, Strategies, and Objectives 106

Structuring Performance Agreements 109

Developing Performance Indicators and Targets 117

5. Financial and Fiscal Discipline 133

Key Concepts and Definitions 134

Reducing Preferential Access to Financing 134

Identifying and Separating Out Public Service Obligations 138

Managing the Fiscal Burden and Fiscal Risk of SOEs 143

6. Board of Directors 159

Key Concepts and Definitions 160

Professionalizing Board Composition 162

Defining and Implementing Board Responsibilities 179

Enhancing Board Professionalism 189

Setting Board Remuneration and Evaluation 196

Providing Board Director Training 203

7. Transparency, Disclosure, and Controls 215

Key Concepts and Definitions 216

Guiding Principles 217

Improving SOE Reporting and Disclosure 220

Improving the Control Environment 228

Undertaking an Independent External Audit 235

8. Special Issues in Mixed-Ownership Companies 243

Key Concepts and Definitions 244

Overview of Issues in Mixed Ownership Companies 244

Overseeing State Minority Shares 246

Protecting the Basic Rights of Minority Shareholders 248

Promoting Shareholder Participation 250

9. Implementing Reform 257

Contextualizing Reform 258

Paying Attention to the Reform Process 261

Appendix A Country-Level Tools: Instruction Sheet 277 
Appendix B Country-Level Tools: Assessment Questionnaire 281

Introduction 281

Glossary of Key Terms 282

Appendix C Country-Level Tools: Sample Survey Instrument 317

Company Identification Data 318

$\begin{array}{ll}\text { Survey } & 319\end{array}$

Appendix D Company-Level Tools: Instruction Sheet 335

Appendix E Company-Level Tools: State-Owned Enterprise Progression Matrix

Appendix F Company-Level Tools: Information Request List and Interview Guide

Financial Discipline $\quad 343$

Board of Directors 344

Transparency, Disclosure, and Controls 346

Treatment of Minority Shareholders 351

Commitment to Corporate Governance 352

Appendix G Company Level Tools: Sample

Company-Level Corporate Governance

Improvement Program

355

State-Owned Enterprise Company 356

\section{Annexes}

4A Examples of Key Performance Indicators for the Water Sector 129

6A IFC-World Bank Progression Matrix for State-Owned Enterprises: Structure and Functioning of the Board 206

6B Guidelines for Centralized Management of the Board Nomination Process 207

6C Advantages and Disadvantages of Different Approaches to Board Evaluation 210

7A IFC-World Bank Progression Matrix for SOEs: Transparency, Disclosure, Control Environment 240

8A IFC-World Bank Progression Matrix for State-Owned Enterprises: Shareholder Rights 254

9A IFC-World Bank Progression Matrix for SOEs: Commitment to Corporate Governance 276 


\section{Boxes}

1.1 The Still Substantial Role of SOEs in Major Emerging Market Economies

1.2 Expanded State Ownership through Nationalization and Acquisition

1.3 Summary of the OECD's Guidelines on Corporate Governance of SOES

2.1 Varied Definitions of SOEs and the Parastatal Sector 26

2.2 Application of Constitutional and Supranational Law 29

2.3 Countries with General Public Enterprise or SOE Laws 30

2.4 Countries with SOEs under Company Legislation 31

2.5 Employee Outcomes during Corporatization in France 39

2.6 New Zealand Rail: From Civil Servants to Private Employees 40

2.7 The United Kingdom's Principles of Competitive Neutrality in Procurement Processes for Custodial Services 42

2.8 The Listing of Petrobras on the Brazilian Stock Exchange 44

2.9 Examples of Countries with Modernized State Ownership Laws 46

2.10 The Philippines Government-Owned and Controlled Corporation Governance Act

2.11 Decree for Improving the Governance of State-Owned Banks in Tunisia

2.12 New Legal Framework for Chile's Codelco 52

2.13 Summary of Norway's Ownership Policy 55

2.14 Summary of Bhutan's Ownership Policy 57

2.15 Corporate Governance Scorecard in the Philippines 63

2.16 Steps in Developing an SOE Governance Code 64

3.1 Challenges and Constraints of Advisory Bodies in India and the United Kingdom 77

3.2 Separation of Ownership and Regulation 79

3.3 A Separate Ministry for State-Owned Enterprises in Indonesia 83

3.4 The Mission of the French Government Shareholding Agency 85

3.5 A Specialized Ownership Agency in China 86

3.6 A State Holding Company in Hungary 89

3.7 An Investment Company in Malaysia 90

3.8 A Sovereign Wealth Fund in Bahrain 92

3.9 Key Lessons from GCC Countries in Achieving Political Insulation 94

4.1 Mandates in State-Owned Development Banks 107

4.2 Past Experience with Performance Contracts 110

4.3 Using Task Forces to Help in Performance Management in India 
4.4 Guidelines for Performance Agreements and Indicators in New Zealand 118

4.5 Measuring Economic Value Added 121

5.1 Taxing Finnish and Norwegian SOEs 138

5.2 Italian Public Service Agreements 141

5.3 Managing the Impact of SOEs on Fiscal Discipline:

An Investigation of the International Monetary Fund 145

5.4 Estimating Fiscal Risks of SOEs 148

5.5 Good Practices for Institutional Arrangements and Reporting Mechanisms for SOE Debt 152

6.1 Duties of Care and Loyalty: Implications for SOE Board Members 161

6.2 Employee Representation on SOE Boards in OECD Countries 164

6.3 A Detailed Definition of an Independent Board Member 167

6.4 Developing a Board Skills Profile 172

6.5 A Formal Advisory Body for Board Nominations: The New Zealand Example 174

6.6 Board Nominations in Four State-Owned Development Banks 175

6.7 Key Responsibilities of a Conventional Board 180

6.8 Delineation of SOE Board Responsibilities in South Africa 181

6.9 Delegating Decision-Making Powers to SOE Boards in India 183

6.10 Codes of Conduct for Central Public Sector Enterprises in India 185

6.11 Establishing an Audit Committee 193

6.12 The Role and Composition of Remuneration and Nomination Committees 195

6.13 Compensation Framework for Government-Linked Corporations in Malaysia 198

7.1 Stock Market Listing Can Lead to Increased Transparency 220

7.2 OECD Guidelines on Disclosure 221

7.3 Integrated Reporting in Practice: The Case of ESKOM in South Africa 228

7.4 Risk Management Guidance for Companies Linked to the Malaysian Government 230

7.5 How São Paulo's Sabesp Used Internal Auditing to Improve the Control Environment 234

9.1 SOE Corporate Governance Reforms in India 263

9.2 Strengthening SOE Oversight and Transparency in Paraguay, 2008-13

\section{Figures}

1.1 Key Stakeholders in Corporate Governance 12

7.1 Main Actors in the Control Environment 229 


\section{Tables}

2.1 Examples of SOE Ownership Policies

3.1 Examples of SOE Advisory and Coordinating Bodies

3.2 Types of Centralized Ownership Arrangements

4.1 Indicators for Monitoring Different Dimensions of SOE Financial Performance

4.2 Nonfinancial Indicators Most Commonly Cited by Large Firms in Canada and the United States

5.1 Criteria for Assessing Fiscal Risks of SOEs

5.2 Examples of Controls over SOE Indebtedness

6.1 Qualification Requirements for Board Directors

B6.9.1 Thresholds Triggering Requirement for Ministry Approval of SOE Actions, India

7.1 Main International Standards on Transparency, Disclosure, and Controls

9.1 Classification of the State-Owned Enterprise Sector in the Middle East and North Africa 


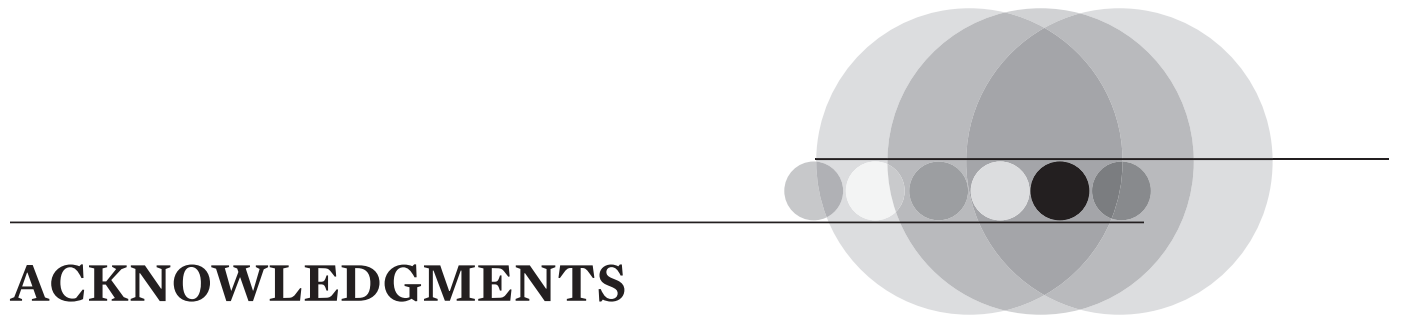

This toolkit was produced jointly by a World Bank team from the Finance and Markets Global Practice (FMGP) and the Governance Global Practice (GGP) of the World Bank Group. It was funded by the World Bank, the International Finance Corporation, the Korea Development Institute School of Public Policy and Management, and the Global Partnership Facility Trust Fund.

The development of the toolkit was led by Sunita Kikeri from FMGP, with Jim Brumby and Alexandre Arrobbio from GGP. The World Bank team comprised Alejandra Nunez, Alexander Berg, Ana Cristina Hirata Barros, Blanca Moreno-Dodson, David Robinett, Henri Fortin, Immanuel Steinhilper, Jose Garrido, Laura Zoratta, Marijn Verhoeven, Renaud Beauchard, and Sanjay Vani. The Toolkit benefited from significant inputs from a number of consultants. Chris Johnson, David Shand, Nilgün Gökgür, Richard Frederick, and Ron Hamilton prepared valuable background papers. James Colvin and Jeffrey Rinne helped with the final restructuring of the toolkit.

The team thanks the many World Bank Group colleagues who provided valuable inputs and comments, including Alexander Pankov, Aurora Ferrari, Bill Dorotinsky, Brian Levy, Charles Canfield, Deepak Mishra, Dusko Vasiljevic, Gary Fine, Ghita Alderman, John Speakman, Jong Wook Lee, Jordan Schwartz, Parminder Brar, Roman Zyla, Sameer Goyal, Sebastian Molineus, William Peter Mako, and Young Kyu Kang. The team appreciates the helpful comments and suggestions provided by external reviewers, including Chris Pierce, and John Nellis, as well as David Erhardt and Alfonso Guzman of the consulting firm Castalia. 
For their overall support, the team thanks Alison Harwood (Practice Manager, Capital Markets, FMGP), Deborah Wetzel and Linda Van Gelder (then Directors of Public Sector in Poverty Reduction and Economic Management), Loic Chiquier (Chief Technical Specialist, FMGP), and Nicholas Manning (then Head, Governance and Public Sector Practice, Poverty Reduction and Economic Management). 


\section{ABBREVIATIONS}

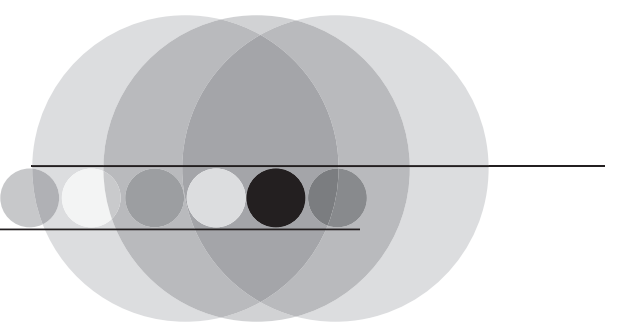

$\begin{array}{ll}\text { APE } & \text { Agence des Participations de l'Etat } \\ \text { CAF } & \text { Corporación Andina de Fomento } \\ \text { CEO } & \text { chief executive officer } \\ \text { COMU } & \text { Corporación Financiera de Desarrollo } \\ \text { CPSE } & \text { central public sector enterprise } \\ \text { DBSA } & \text { Development Bank of South Africa } \\ \text { DHI } & \text { Druk Holding and Investments } \\ \text { DPE } & \text { Department of Public Enterprises } \\ \text { EU } & \text { European Union } \\ \text { GCC } & \text { Gulf Cooperation Council } \\ \text { GOCC } & \text { Government-Owned and Controlled Corporation } \\ \text { COSO } & \text { Committee of Sponsoring Organizations of the Treadway } \\ & \text { Commission } \\ \text { GDP } & \text { gross domestic product } \\ \text { GCL } & \text { government-linked company } \\ \text { FONAFE } & \text { Fondo Nacional de Financiamiento de la Actividad } \\ \text { IAS } & \text { Empresarial del Estado } \\ \text { IFC } & \text { International Accounting Standard } \\ \text { IFRS } & \text { International Finance Corporation } \\ \text { IGEPE } & \text { International Financial Reporting Standards } \\ \text { IMF } & \text { International Monetary Fund } \\ & \end{array}$


IPO initial public offering

KPI key performance indicators

MNV Zrt., Hungarian State Holding Company

MOF ministry of finance

MOSE Ministry of State-Owned Enterprises

MOU memorandum of understanding

NZRC New Zealand Rail Corporation

OECD Organisation for Economic Co-operation and Development

PIE public interest entity

PSA public service agreement

PSO public service obligation

ROSC Report on the Observance of Standards and Codes

SAI supreme audit institution

SEC State Enterprise Commission

SEP Sistema de Empresas

SASAC State-Owned Assets Supervision and Administration Commission

SOE state-owned enterprise

UNCTAD United Nations Conference on Trade and Development

VAT value-added tax 


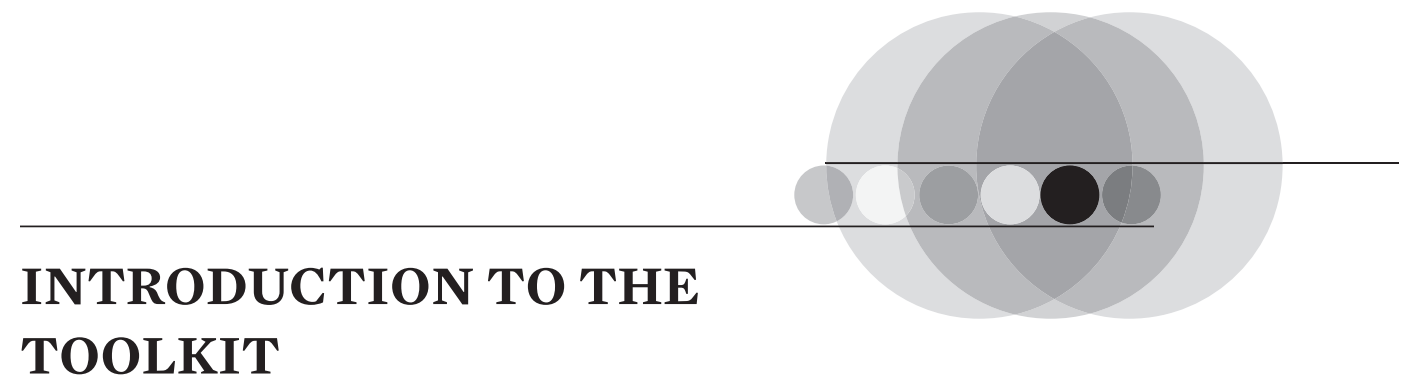

\section{Objectives}

This toolkit provides an overarching framework for the corporate governance of state-owned enterprises (SOEs), along with the tools and information for making practical improvements. ${ }^{1}$ Drawing on global good practices, reform experiences, and a growing body of knowledge, the toolkit is designed to assist practitioners in creating, implementing, and monitoring SOE corporate governance reforms and in building the capacity to carry them out.

The primary audience for the toolkit is the government officials and SOE managers responsible for preparing and implementing SOE governance reforms. While the toolkit offers guidance on the policy and implementation challenges for this group in particular, it may also be a reference point for other stakeholders, including SOE employees, other regulatory bodies and institutions, the private sector, consumers, and citizens.

The toolkit focuses on commercial SOEs at the national level in which the government has significant control through full, majority, or substantial minority ownership. SOEs across a range of sectors-such as manufacturing and services, utilities, banks and other financial institutions, and natural resources-are included. Corporate governance issues and reform options are similar in most such companies, although there may be significant differences in emphasis by sector, which are highlighted where relevant. While the toolkit is focused mainly on commercial SOEs rather than noncommercial entities that fulfill special public policy purposes (whether or not in corporate form), the frameworks and tools may still be relevant. Similarly, although the toolkit does not cover municipal SOEs, many of the concepts and approaches are relevant for them as well. 
Despite the fact that lessons on SOE corporate governance are still emerging, experience shows that no one strategy is universally applicable and that the choice of measures depends on country- and enterprisespecific circumstances. The toolkit thus provides a range of frameworks, concepts, case examples, checklists, and model documents that together aim to help government officials make the appropriate choices for their circumstances. Users of the toolkit should be better prepared for the following activities:

- Understanding the concepts, benefits, challenges, and key issues related to designing and implementing SOE corporate governance reforms

- Choosing among available options and approaches based on prevailing economic, political, social, and financial circumstances

- Formulating policies and procedures for carrying out and monitoring SOE corporate governance reforms

- Managing the reform process, including prioritizing and sequencing of reforms, capacity building, and stakeholder engagement.

\section{Structure of the Toolkit}

The toolkit consists of nine chapters and a set of tools as described below:

- Chapter 1, "Context and Overview." This chapter provides the overall context for why countries the world over are undertaking SOE governance reform, focusing in particular on the importance and benefits of good corporate governance. In setting the context, the chapter provides an overview of past SOE reform efforts, the role and importance of SOEs, the performance of SOEs and the broader economic and financial consequences, the governance challenges facing SOEs, the benefits of good corporate governance, and a framework for reform.

- Chapters 2-8. These chapters address the key elements of corporate governance. Chapters 2-5 examine policy measures that can be adopted within the machinery of government to promote better SOE governance, while chapters 6-8 look at the internal governance arrangements in SOEs and how these can be optimized to ensure better financial and operational performance and to protect minority shareholders in mixedownership companies.

- Chapter 2, "The Legal and Regulatory Framework.” This chapter focuses on how to establish and implement a sound legal and regulatory framework that becomes the foundation for good corporate governance, including 
through the passage of laws and regulations, ownership policies, and corporate governance codes.

- Chapter 3, "State Ownership Arrangements." This chapter discusses how governments can improve their role as owner by setting up appropriate arrangements for exercising their core ownership rights. It examines different ownership models and their pros and cons, offers a pathway for improving these arrangements, and identifies steps for ensuring their effectiveness.

- Chapter 4, "Performance Monitoring." This chapter looks at how to monitor performance and hold SOEs accountable for results through the establishment of proper monitoring systems based on clearly defined mandates, strategies, and objectives with structured performance agreements and key performance indicators and targets.

- Chapter 5, "Financial and Fiscal Discipline." This chapter examines the methods that governments can adopt to enhance the financial and fiscal discipline of SOEs, including through reducing preferential access to financing, identifying and separating public service obligations, and managing the fiscal burden and fiscal risk of SOEs.

- Chapter 6, "Board of Directors." This chapter focuses on how to professionalize SOE boards by developing a proper framework for board nominations, clarifying and implementing board responsibilities, increasing board professionalism, developing board remuneration and evaluation policies, and providing director training.

- Chapter 7, "Transparency, Disclosure, and Controls.” This chapter addresses how to improve SOE transparency and disclosure, which are vital to holding SOEs accountable for their performance. The chapter covers the guiding principles on transparency and disclosure, the reporting of financial and nonfinancial information, the control environment, and the role of independent external audits.

- Chapter 8, "Special Issues in Mixed-Ownership Companies.” This chapter discusses key corporate governance issues that arise in mixed-ownership companies, including the need for assigning clear responsibility for overseeing state minority shares, protecting the basic rights of minority shareholders, and promoting shareholder participation.

- Chapter 9, "Implementing Reform." This chapter highlights the challenges of implementing reform and covers issues such as the phasing and sequencing of reforms, capacity building, stakeholder engagement, and the need for carrying out corporate governance reforms in parallel with broader SOE reforms. 


\section{Corporate Governance Tools}

To provide step-by-step guidance for evaluating and improving the corporate governance of SOEs, the toolkit provides tools for both the country and the company levels. The tools described below are found in the appendixes.

\section{Country-Level Tools}

Developed by the World Bank, country-level tools are designed to assess the strengths and weaknesses of the corporate governance framework for SOES in a particular country and to propose improvements in the framework. The focus is on SOEs using a distinct legal form (that is, separate from the public administration) and having a commercial activity, with the bulk of their income from sales and fees. The country-level tools include the following:

- Instruction sheet for country-level assessment. The instruction sheet describes each of the tools, how they should be used, and who should be interviewed in the course of the assessment.

- Country-level assessment questionnaire. The questionnaire contains a list of questions and requests for documentation that forms the basis for the assessment. The questionnaire is organized along the lines of the nine chapters in the toolkit. The assessment can be a comprehensive assessment covering all nine chapters or selected chapters can be covered. The questionnaire seeks to identify issues related to the role and performance of SOEs in the economy; the main elements of the legal and regulatory framework; the state's ownership arrangements; the performancemonitoring system for SOEs; financial and fiscal discipline of SOEs; boards of directors; transparency, disclosure, and controls; treatment of minority shareholders; and commitment to governance.

- Sample SOE survey questionnaire. The survey questionnaire is designed to go beyond an assessment of the legal and regulatory framework and to capture specific company practices. It covers all nine chapters of the toolkit and is meant to be used as a starting point for understanding company practices and identifying areas for improvement. The survey questionnaire should be customized to local circumstances and be sent to SOEs by the country authorities to increase the response rate and build trust.

\section{Company-Level Tools}

Adapted from the Corporate Governance Development Framework of the International Finance Corporation (IFC), company-level tools are designed 
to assess and improve the corporate governance of individual SOEs. The tools are based on IFC's overall methodology for assessing and improving the corporate governance of its investee companies (including listed companies, family companies, financial institutions, privatized transition economy companies and SOEs). The SOE tools include the following:

- Instruction sheet for SOEs. The instruction sheet describes the tools, how they should be used, and who should be interviewed in the course of evaluating and improving SOE corporate governance.

- SOE progression matrix. The progression matrix covers five areas of company level governance and relates them to four levels of achievement, from acceptable corporate governance practices (level 1) to leadership practices (level 4). The five corporate governance areas are financial discipline (chapter 5); boards of directors (chapter 6); transparency, disclosure, and controls (chapter 7); treatment of minority shareholders (chapter 8); and SOE commitment to good corporate governance (chapter 9). The five areas are included at the end of each chapter, while a complete matrix is provided in the appendix. The progression matrix provides detailed stepby-step procedures for evaluating where an individual SOE's governance stands and what practical steps can be taken to improve it. The use of the matrix emphasizes the importance of ongoing improvements in the governance practices of SOEs, rather than advocating the application of rigid and static minimum standards. In particular, the progression matrix allows SOEs, and their owners, to assess the governance of the company against a simple framework and to develop steps for improvement.

- Information and document request list. This tool consists of a comprehensive and detailed list of questions and document requests that form the basis for the corporate governance analysis and improvement plan for an SOE. The list covers the five areas of SOE governance covered in the progression matrix. Questions must be selected that are appropriate for the particular context. The information and document list should be circulated to the company at least three weeks in advance of any review or assessment. The company should identify a single officer who will be charged with responding to the information request list.

- Corporate governance improvement program. This tool consists of a sample corporate governance improvement program based on the corporate governance review.

The above tools can also be found at http://ifcnet.ifc.org/ifcint/corpgov.nsf /Content/CGTools_State_owned_enterprises. 



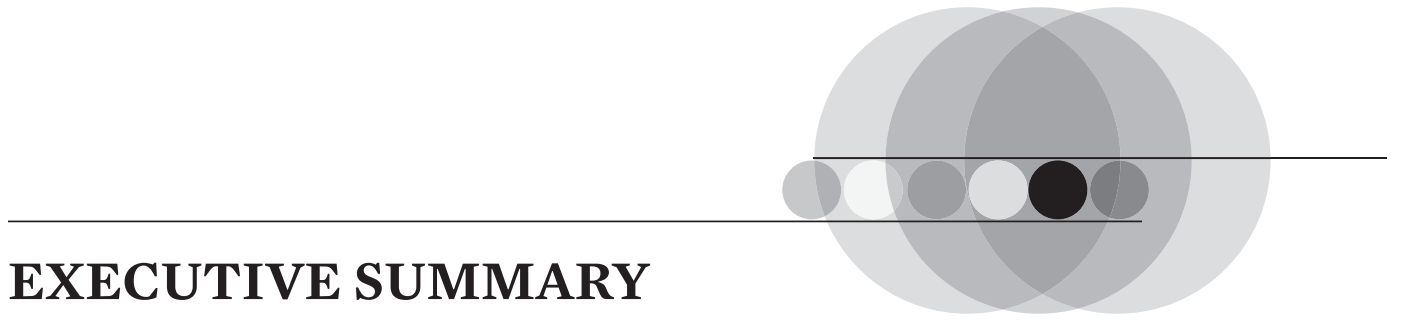

Despite the trend toward privatization over the past 20 years, state-owned enterprises (SOEs) are still significant economic players. Globally, SOEs account for 20 percent of investment, 5 percent of employment, and up to 40 percent of output in some countries. They continue to deliver critical services in important economic sectors such as utilities, finance, and natural resources. Even in competitive industries, enterprises in large-scale manufacturing and services remain in state hands in many countries.

Unlike in the past, however, SOEs today are under strong pressure to improve their performance. These pressures come various sources, including the need to enhance their competitiveness and that of the economy as a whole, especially in countries where SOEs are major players; to provide essential infrastructure, financial, and other services to businesses and consumers more efficiently and cost effectively; to reduce their fiscal burden and fiscal risk; and to enhance the transparency and accountability of the use of scarce public funds. Increasing globalization, deregulation of markets, and budgetary discipline are also driving efforts to improve performance. A long history of efforts at reform shows that the key to better SOE performance is better governance.

Demand for good governance has led to a growing body of knowledge and analytical work. The World Bank Group has integrated corporate governance and fiscal and financial management into its broader SOE reform efforts, assessing the state of corporate governance in SOE sectors in various countries, providing policy recommendations and actions plans, and supporting reform implementation through its advisory and lending operations. Drawing from its Principles of Corporate Governance, the Organisation for Economic Co-operation and Development (OECD) issued its Guidelines on the Corporate Governance of State-Owned Enterprises (OECD 2005), which 
provides a benchmark for assessing corporate governance practices in different countries. Since then, numerous OECD publications have been published on such important areas as SOE boards of directors, transparency and accountability, and competitive neutrality. Numerous other international, regional, and country-level organizations have also contributed to a growing volume of work on SOE governance.

\section{Importance and Benefits of Good Corporate Governance}

Chapter 1 shows that, despite extensive privatization over the years, governments around the world continue to own and operate commercial enterprises in such critical sectors as finance, infrastructure, manufacturing, energy, and natural resources. ${ }^{2}$ Evidence points to the continued presence, and even expansion, of state-owned sectors in high-income countries, in major emerging market economies, and in many low- and middle-income countries. Indeed, many SOEs now rank among the world's largest companies, the world's largest investors, and the world's largest capital market players. In many countries, SOEs in strategic industries are increasingly viewed as tools for accelerated development and global expansion.

The performance of SOEs has improved in many cases due to greater competition, exposure to capital market discipline, and better governance practices. Yet many SOEs continue to underperform, with high economic, financial, and opportunity costs for the wider economy. Inefficient provision of critical inputs and services can increase costs for local businesses and divert scarce public sector resources and taxpayers' money away from social sectors that directly benefit the poor. Assets that could be used more productively elsewhere in the economy may be tied up. And poorly performing SOEs cannot access financing through the capital markets, which is critical to infrastructure and financial sector development.

Past efforts at reform have made clear that poor SOE performance, where it occurs, is caused less by exogenous or sector-specific problems than by fundamental problems in their governance-that is, in the underlying rules, processes, and institutions that govern the relationship between SOE managers and their government owners. Driven by the divergence of political interests between ownership (by the government on behalf of the citizens of the country) and control (by the directors and managers that run the company), these governance problems can include complicated and at times contradictory mandates, the absence of clearly identifiable owners, politicized boards and management, lack of autonomy in day-to-day operational decision making, 
weak financial reporting and disclosure practices, and insufficient performance monitoring and accountability systems. Where these shortcomings are more common, SOEs may also be a source of corruption.

Many countries have taken concrete and significant steps to address these challenges, improve their operations, and achieve the benefits of good corporate governance. Evidence shows that a good corporate governance system in a country is associated with a number of benefits for all companies, whether private or state owned. These benefits include better access to external finance by firms, which in turn can lead to larger investments, higher growth, and greater employment creation; lower costs of capital and higher firm valuation, which make investments more attractive and lead to growth and greater employment; improved operational performance through better allocation of resources and more efficient management, which create wealth more generally; reduced risk of corporate crises and scandals, particularly important given the potentially large economic and social costs of financial crises; and better relationships with stakeholders, which help improve social and labor relationships, help address such issues as environmental protection, and can help further reduce poverty and income inequality.

Taken together, these benefits can boost the efficiency of SOEs and, in turn, that of the economy as a whole and make transactions among companies more competitive and transparent; result in more efficient allocation of resources by reducing the fiscal burden and fiscal risk of SOEs; lead to greater public and private investment in critical sectors such as infrastructure that contribute to competitiveness and growth; and reduce vulnerabilities in the financial system and promote financial sector development more broadly.

\section{Key Corporate Governance Elements}

Chapters 2-8 of the toolkit focus on the overall framework and the key elements for improving SOE corporate governance, both for their state owners and for specific companies. The chapters describe a number of good practices, implementation steps, and tools and include experiences from a wide range of countries. Several elements contribute to improved SOE governance:

- Establishing a sound legal and regulatory framework for corporate governance (chapter 2) by

- Bringing SOEs under company law and applying other laws and regulations to SOEs to create a level playing field.

- Listing them on the stock markets to create capital market discipline. 
Developing modern SOE laws and regulations.

- Uniting SOEs under a national code of corporate governance or creating a specific SOE code to codify good practices.

- Creating proper ownership arrangements for effective state oversight and enhanced accountability (chapter 3) by

- Identifying and separating the state's ownership functions from its policy-making and regulatory functions.

- Developing appropriate arrangements for carrying out ownership functions.

- Creating safeguards against government interventions.

- Centralizing the state's ownership functions to bring focus, consistency, and good practices to the SOE sector.

- Developing a sound performance-monitoring system (chapter 4) by

- Defining SOE mandates, strategies, and objectives.

- Developing key performance indicators and targets, both financial and nonfinancial.

- Establishing performance agreements between SOE owners and SOE boards.

- Measuring and evaluating performance with the goal of holding SOEs accountable for results and ensuring good performance.

- Promoting financial and fiscal discipline (chapter 5) by

- Reducing preferential access to direct and indirect public financing.

- Identifying, computing, and financing the true cost of public service obligations.

- Monitoring and managing the fiscal burden and potential fiscal risk of SOEs.

- Professionalizing SOE boards (chapter 6) by

- Developing a structured and transparent process for board nominations.

- Defining the respective roles of the state, as owner, of boards, and of management and empowering boards with core responsibilities such as strategy setting, choosing and overseeing the chief executive officer (CEO), and managing risks.

- Enhancing board professionalism through the separation of chair and CEO, development of board committees, and the like.

- Putting in place board remuneration and evaluation policies and practices.

- Providing training to members of boards of directors.

- Enhancing transparency and disclosure (chapter 7) by

- Applying private sector principles and international standards to SOEs. 
Improving SOE reporting and disclosure.

Strengthening the control environment.

- Carrying out independent external audits.

- Protecting shareholder rights in mixed-ownership companies (chapter 8) by

- Overseeing minority government stakes.

- Promoting shareholder participation and equitable treatment of shareholders.

- Encouraging participation in shareholders' meetings.

- Ensuring representation of minority shareholders on SOE boards.

- Protecting against abusive related-party transactions.

\section{Implementing Reform}

Chapter 9 concludes with a focus on reform implementation. Diagnosing governance challenges and developing appropriate policy and technical solutions are critical starting points in planning reform. But the real challenge is one of implementation. Given the variety of circumstances in different countries and sectors, no "one-size-fits-all" approach will work. Circumstances in low- and middle-income countries are widely different from those in OECD member states or in major emerging markets, while fragile postconflict states face unique challenges of their own. This variation suggests a need for flexibility in adopting good practices and in tailoring them to social norms and traditions, as well as to the realities on the ground.

Moreover, the entire package of governance reforms as described above may not be feasible, or necessary, to put in place all at once. Governance reforms-and SOE reforms more broadly-are politically contentious and can be challenging to implement. Vested interests within SOEs and government may render reforms more complex: SOE management may see better governance as a threat to its independence; SOE boards can see reform as a threat to their positions; and line ministries may be resistant to changes that threaten their capacity to use the SOEs within their control. Outside of government, stakeholders can also oppose change. Employees may be worried about job security, when reform is tied to efficiency or operational improvements. Preferred suppliers and customers may object to greater transparency in SOE commercial dealings, and other shareholders might prefer the status quo, particularly if benefits accrue to an SOE because of its government ownership. 
Overcoming these challenges can be difficult. But experience shows that it can be done by devoting attention to the reform process itself. This involves:

- Securing political leadership and commitment. Without that leadership, reform is not likely to get off the ground.

- Phasing or sequencing reforms on the basis of their political and institutional feasibility. Not only is phasing important in overcoming entrenched interests, but it also supports the concept of governance reform and provides the confidence that policy makers need to take further steps. Where opposition is strong, reforms can start with less controversial actions, for example, by bringing in more independent directors from the private sector, providing training for board members, developing a performancemonitoring framework, and monitoring SOE disclosure. Where local corporate governance standards are reasonably strong and the country has a stock exchange, listing SOEs on the stock market can be a first step toward disciplining these enterprises and improving governance. More difficult reforms such as development of SOE laws and centralization of the ownership function may require time, and changes in mindset and public opinion are likely to occur as other reforms take hold and create pressures for these reforms.

- Gathering and publishing comprehensive data on SOE performance. Central agencies can build momentum for change by developing and publishing better aggregate information on the performance of SOEs and their true costs and benefits to government. Basic information is also important for diagnosing and implementing reforms. As a less contentious process, it can help build the capacity and ownership for reforms. Prioritizing this reform can also benefit the internal governance of SOEs since it drives capacity development within the enterprises and can lead to better internal information for management and the board of directors.

- Supporting improvements in companies. In countries with large SOE sectors, improving corporate governance of the sector as a whole can be daunting and will take time. Governance efforts could focus initially on a few companies to demonstrate concrete results. Good outcomes will help focus the state on its role as shareholder and lead to higher performance and better transparency of key SOEs. It also provides tangible improvements and benefits that could create momentum for implementation across all SOEs.

- Building institutional capacity to manage and sustain the reform process. Building and strengthening capacity at all levels is needed. Owners, 
regulators, boards, and senior management will need a comprehensive understanding of corporate governance in general as well as from their individual perspectives. To remain steadfast in promoting good corporate governance, ownership units will need people with knowledge, skills, and experience in business; and when such employees cannot be recruited or seconded, existing personnel will have to receive the appropriate training and exposure to development programs in corporate finance and economics. In low-capacity countries, significant technical assistance may be required in the start-up phase. Companies' boards, management, and staff too will require intensive training and capacity building. Corporate governance requires knowledge and skills that are not present in many SOEs in low-income countries or in countries that are just starting out on these reforms more broadly. The focus of training and capacity building should be on substance over form and on behavioral changes over structural.

- Building support for reform among stakeholders and the public. SOEs often have a long history and are seen as crucial components of a nation's economy. Because SOE reform is frequently viewed as a precursor to privatization, the public is often highly skeptical of the value of such reforms. Conversely, where SOEs do not operate efficiently, waste and mismanagement issues can spark a public debate on the benefits of reform. In this context, effectively communicating the objectives of good governance and its potential outcomes can increase stakeholders' support for those objectives and influence opinions, attitudes, and behavioral changes. Centralized ownership units can use their unique position to advocate change and to document its benefits. Aggregate ownership reports, such as performance scorecards, and benchmarking reports, can both illustrate the need for reform and document progress.

Finally, reforming governance alone will not solve SOE problems. Lessons from past experiences suggest that a comprehensive approach is needed. Corporate governance reforms should be accompanied by other reforms such as SOE restructuring and privatization. According to substantial evidence, privatization and public-private partnerships have brought big gains for many SOEs, in both competitive and noncompetitive sectors. Where privatization is not a preferred policy option, SOEs can still be exposed to capital market discipline through partial listings. Removing barriers to entry and exit are also important, and governments should continue with broader reforms to develop the private sector. 


\section{Notes}

1. The toolkit does not address broader policy questions on state ownership.

2. Subnational governments and municipalities also have commercially oriented public enterprises; past reforms focused on those operating at the central or federal levels. Recently, governments and international financial institutions have begun to pay attention to municipal SOEs because of their performance problems and the fiscal burden and fiscal risk that they impose. These enterprises are beyond the scope of this toolkit. Nevertheless, governance measures similar to those discussed in the toolkit would improve their performance as well.

\section{Reference}

OECD (Organisation for Economic Co-operation and Development). 2005. OECD Guidelines on Corporate Governance of State-Owned Enterprises. Paris: OECD. 


\section{CHAPTER 1}

\section{Context and Overview}

Understanding the overall context-including the importance and benefits of good corporate governance-is a first and essential step toward reforming the governance of state-owned enterprises (SOEs). This chapter explains why countries the world over are seeking to improve SOE governance and provides an overview of the following topics:

- Past SOE reforms

- Role and importance of SOEs

- SOE performance and its impacts

- Governance challenges facing SOEs

- Benefits of good corporate governance

- Overarching framework for reform

\section{Past SOE Reforms}

Governments worldwide have long established SOEs with a variety of public policy goals in mind-building basic physical infrastructure; providing essential services such as finance, water, and electricity; generating 
revenue for the treasury; achieving self-sufficiency in the production of basic goods and services; controlling natural resources; addressing market failures; curbing oligopolistic behavior; and promoting social objectives such as employment generation, regional development, and benefits for economically and socially disadvantaged groups.

While SOEs have come to play an important economic role, evidence from the 1970s and 1980s from a number of countries shows that, on average, SOEs have performed poorly relative to private firms, partly because multiple policy goals proved difficult to reconcile. ${ }^{1}$ SOEs often incurred substantial financial losses and became an unsustainable burden on the national budget and banking system. Government policies in support of SOEs slowed the development of the private sector, crowded out private firms from credit markets, and limited the potential for expansion of the private sector.

Since the 1980s, reforms have sought to improve performance by exposing SOEs to competition, imposing hard budget constraints, and introducing institutional and managerial changes. Many SOEs were commercialized and later corporatized into separate legal entities. In addition, governments developed performance contracts with SOEs to monitor performance and hold managers accountable for results.

Although these early reforms produced some improvements, they often fell short in implementation. The politicization of SOE boards made it difficult to provide greater autonomy in commercial decision making. The separation of commercial and social objectives was widely advocated, but few governments calculated the true cost of meeting public service obligations and transferred the necessary resources to SOEs. The achievement of financial discipline through a hard budget constraint proved difficult without corresponding restrictions on SOE borrowing from the banking system and from state-owned banks in particular. And while greater autonomy for SOEs hinged on having good accountability mechanisms, performance contracts were difficult to implement or were of mixed quality. Backsliding was common, and often reforms could not be sustained (Kikeri, Nellis, and Shirley 1992).

The modest outcomes of the reforms, difficulties in sustaining improvements in performance, and changing political systems led governments in the 1990s to turn to privatization as a way to remove SOE deficits from the national budget, to attract private investors with capital and managerial know-how, and to prevent backsliding and "lock in" efficiency gains from SOE reforms. During the 1990s and first few years of the 2000s, both financial and nonfinancial SOEs were privatized through various means, including strategic sales, auctions, vouchers, management and employee buyouts, leases and concessions, and public stock offerings. ${ }^{2}$ Countries around the 
world witnessed a decline in the number of SOEs as a result of privatizations, mergers, and liquidations. Evidence also showed that privatization improved firm performance in competitive sectors and, when accompanied by proper policy and regulatory frameworks, in financial and infrastructure sectors as well (Kikeri and Nellis 2004; Nellis 2011).

However, when privatization was not done right and when the required institutional frameworks were lacking-often the case in low-income settings-privatization ended in failures and scandals that led to a backlash against the process (Nellis and Birdsall 2005). Privatization proved politically problematic, in large part because its economic benefits, while often substantial, tended to occur in the medium to longer term and were dispersed widely, in small increments, among a very broad range of stakeholders. Its costs, however, were concentrated, substantial, and immediate and felt by vocal and powerful groups. Moreover, privatization often raised sensitivities about foreign ownership of so-called strategic enterprises. It was generally unpopular with the public because of higher infrastructure tariffs, employment losses, and some corrupt transactions. Political opposition deterred many governments from privatizing large SOEs in complex sectors such as finance and infrastructure. Others privatized only partially, with the state remaining a majority or controlling shareholder, or governments imposed efficiency-diminishing conditions (for example, no layoffs) on new private owners.

Combined with the 2007-08 global financial crisis that led to turmoil in the capital markets and reduced investor interest, these factors further slowed privatization and brought it to a near halt after 2008. Indeed, the crisis itself triggered new debates on the role of the state in the economy. Together, these factors pushed governments the world over to refocus their attention on improving SOE performance.

\section{Role and Importance of SOEs}

Despite extensive privatization, governments continue to own and operate national commercial enterprises in such critical sectors as finance, infrastructure, manufacturing, energy, and natural resources. State-owned sectors in high-income countries, in major emerging market economies, and in many low- and middle-income countries have continued, and even expanded. Indeed, many SOEs now rank among the world's largest companies, the world's largest investors, and the world's largest capital market players. In many countries, SOEs in strategic industries are increasingly viewed as tools for accelerated development and global expansion. 
While systematic and recent data are hard to come by, a number of stylized facts have become clear. ${ }^{3}$ First, SOEs continue to play an important economic role, irrespective of geographic region or degree of economic development:

- Globally, in 2006 SOEs accounted for 20 percent of investment and 5 percent of employment (Robinett 2006).

- According to a 2009 OECD survey, 25 OECD countries had a total of some 2,050 SOEs valued at US\$1.2 trillion. These SOEs accounted for 15 percent of gross domestic product (GDP), as measured by the valuation of SOE sectors relative to GDP, and, in countries still undergoing the transition to a more market-based economy, for 20-30 percent of GDP (OECD 2011). ${ }^{4}$

- In less developed countries, SOEs produced about 15 percent of regional GDP in Africa, 8 percent in Asia, and 6 percent in Latin America in 2006 (Robinett 2006). In the Middle East and North Africa, SOEs account for 20-50 percent of economic value added across the region and close to 30 percent of total employment (OECD 2012). In Central Asia in 2005, they accounted for more than 50 percent of GDP in Tajikistan, Turkmenistan, and Uzbekistan and for 20-40 percent in others (Kikeri and Kolo 2006).

- SOEs remain central economic players in the major emerging markets of China, India, and the Russian Federation, even as the private sector share of GDP has risen over the years (box 1.1). In Indonesia, some 150 SOEs contribute 15-40 percent of GDP, mostly accounted for by the 22 largest SOEs (Abubakar 2010).

- In fragile and postconflict states such as Afghanistan, Iraq, Liberia, and others, SOEs play, and are expected to play, an important role in the transition to a sustainable economy.

Second, SOEs are especially prominent in sectors of the economy that provide critical services for businesses and consumers and that contribute directly to economic growth and poverty reduction:

- Infrastructure. In many if not most countries, SOEs continue to provide power, rail, and water services, as well as telecommunications services in some countries. Among OECD countries, SOEs in utility sectors account for 50 percent of total SOE value (OECD 2011).

- Banking and other financial services. State ownership in commercial banks has declined considerably over the past four decades, from an average of 67 percent of total banking assets in 1970 to 22 percent in 2009 (World Bank 2012). Yet, SOEs in this sector occupy a dominant 
BOX 1.1

\section{The Still Substantial Role of SOEs in Major Emerging Market Economies}

In China, widespread reforms under the Ninth Five-Year Plan (1995-2000) greatly expanded the role of the private sector and reduced the size of the state-owned sector. The state's share in the total number of industrial enterprises fell from 39.2 percent in 1998 to 4.5 percent in 2010, its share of total industrial assets dropped from 68.8 percent to 42.4 percent, and its share of employment shrank from 60.5 percent to 19.4 percent. The SOE share of China's exports fell from 57 percent in 1997 to 15 percent in 2010. As a result, SOEs' share of GDP declined from 37.6 percent in 1998 to just about 30 percent today, while the number of SOEs dropped from 262,000 to 116,000 . Nevertheless, the "commanding heights" of the economymost notably the 120 or so large central enterprises in such sectors as electricity, petroleum, aviation, banking, and telecommunications-remain largely state owned. State ownership is still present in competitive sectors such as wholesale trade, retailing, and restaurants, and SOEs accounted for 27 percent of industrial output in 2010 (World Bank and Development Research Center 2013). Moreover, the share of SOEs in total investment has increased with the postcrisis stimulus in construction and infrastructure (although the SOE share in production has not risen and the longterm trend is a decline). While private enterprises substantially outpaced SOEs before the global financial crisis, since the crisis the state and private sectors have been growing at broadly similar rates. And while the weight of SOEs in production and assets (of large industrial companies) has declined markedly, the decline has bottomed out in recent years.

In Russia, the SOE share in industrial production fell from 9.9 percent in 1994 to 6.7 percent in 2004. But federal SOEs remain concentrated in sectors that were declared "strategic" in a 2004 presidential decree, including machine building, natural resource exploration and extraction, the military complex, radioactive materials, and radio, broadcasting, and newspapers with a circulation exceeding 1 million. The national government also owns stakes of 10-20 percent in joint-stock companies (Sprenger 2008).

In India, the SOE share of GDP (central, state, and local) declined from 17.5 percent in 1993-94 to 13.1 percent in 2006-07. This decline in the contribution of SOEs occurred across almost all sectors as a result of the removal of entry barriers and other policy measures. Yet, in 2006-07 SOEs still accounted for 67 percent of output in the utility sector; 39 percent in transport, storage, and communications; and 20 percent in banking, insurance, real estate, and business services (OECD 2009). 
position in many cases. In 2010, state banks exceeded half the assets of the banking systems in Algeria, Belarus, China, the Arab Republic of Egypt, India, and the Syrian Arab Republic. In other major emerging market countries-such as Argentina, Brazil, Indonesia, the Republic of Korea, Poland, Russia, and Turkey-state banks do not lead the process of credit creation but still have an asset market share between 20 and 50 percent (World Bank 2012). In 2010, at least 10 of the 18 largest banks in emerging markets were state controlled (Economist, May 15, 2010).

- Oil and gas. The 13 largest oil companies, controlling 75 percent of global oil reserves and production, are state owned, while conventional multinationals produce only 10 percent of the world's oil and hold just 3 percent of known reserves (Economist, January 23, 2010).

- Industry and services. The presence of SOEs has generally declined in these sectors, with notable exceptions. In Vietnam, for example, SOEs enjoy near-monopoly status in the production of several goods and services, including fertilizer (99 percent), and have maintained a large presence in such consumer goods as cement ( 51 percent), beer (41 percent), refined sugar (37 percent), textiles (21 percent), and chemicals (21 percent) (World Bank 2011).

Third, many large SOEs, based in developed and major emerging market economies, are now global players:

- SOEs are among the world's biggest companies. In 2009, four statecontrolled companies made it to the top 25 of the 2009 Forbes Global 2000 list (Economist, January 23, 2010). Almost 25 percent of the top 100 multinational corporations from such countries as China, India, and Russia were state owned in 2006, predominantly in the primary sectors (oil, gas, and mining) and resource-based manufacturing (metals, steel) (UNCTAD 2007).

- SOEs are among the world's biggest investors. Many large SOEs from countries such as Brazil, China, Russia, and India are actively investing abroad, in green-field ventures, as well as in cross-border mergers and acquisitions.

- SOEs are among the world's biggest capital market players. Recent years have seen a noticeable trend of listing large and important financial and nonfinancial SOEs on stock exchanges as a way to raise capital, impose capital market discipline on the enterprises, and dilute state ownership. Between 2005 and 2007, initial public offerings of SOEs in China and Russia were among the largest in history (Kikeri and Burman 2007; Kikeri and Phipps 2008). In turn, initial public offerings of SOEs in these and other countries contributed to capital market development, with SOEs 
accounting for about 30 percent of total market capitalization in Malaysia; 30 percent in Indonesia (Abubakar 2010); 20 percent in India (OECD 2009); and 45 percent in the Middle East and North Africa, taking into account 32 of the 100 largest listed companies, 29 of these based in the Persian Gulf area.

Fourth, some countries are establishing new SOEs to develop strategic industries and compete in an increasingly globalized economy:

- Russia has created state-owned holding companies and state corporations, such as the United Shipbuilding Corporation and the Joint Stock United Aircraft Corporation (Sprenger 2008).

- In the Middle East and North Africa, the Gulf Cooperation Council (GCC) countries have established new SOEs-often with explicit or implicit industrial development agendas-both planned and through state rescue of companies in the aftermath of the global financial crisis (OECD 2012).

- In Vietnam, the steady decline in the number of majority or wholly owned national and local SOEs-from 5,800 in 2000 to 3,300 in 2010-was reversed in 2009, when 175 new SOEs were added by the central government. These include large economic groups and general corporations that were created to develop strategic industries and carry out welfare and social responsibilities (World Bank 2011).

- Following the crisis, in a number of countries state development banks (that have explicit policy mandates and are funded primarily by deposits) and development finance institutions (funded mainly by nondeposit resources) played a countercyclical role by providing credit to private firms that were unable to access funding through private banks and the capital markets. New development banks are also being established in countries such as Malawi, Mozambique, and Serbia among others (de Luna-Martinez and Vicente 2012).

Fifth, a few countries have expanded state ownership through nationalization and through the acquisition of stakes in private enterprises:

- Beginning in 2006, Argentina, Bolivia, Russia, and the República Bolivariana de Venezuela nationalized companies as a matter of policy to increase the state presence in selected sectors (box 1.2).

- More recently, the 2007-08 global financial crisis led to an increase in government ownership as governments of developed countries, such as Iceland, the Netherlands, the United Kingdom, and the United States, bailed out financial institutions through capital injections and partial or full nationalizations-although these interventions were primarily temporary rescues rather than permanent takeovers. 
BOX 1.2

\section{Expanded State Ownership through Nationalization and Acquisition}

In 2006, the government of the República Bolivariana de Venezuela took over majority control of 32 marginal oil fields managed by foreign oil companies and the following year adopted a decree giving the stateowned oil company PDVSA a majority equity share and operational control of four joint ventures. The government also declared energy and telecommunications "strategic." As a result of recent agreements, the government now controls the country's telecommunications company (CANTV) and electricity company (EDC).

Bolivia adopted a decree for the nationalization of oil and gas resources in May 2006, and the government renationalized the two refineries acquired by Brazil's Petrobras during an earlier privatization program. It is now moving to take over ENTEL, the telecommunications company that was privatized in 1996.

In Russia, the state began increasing its presence in key sectors of the economy in 2007 through the acquisition of private company assets by government-related companies (those that are directly controlled by the state and in which the state owns more than 50 percent of common stock). Examples include Rosneft's purchase of a small private oil company, Gazprom's purchase of Sibneft, and the purchase of smaller competitors by five big state-owned banks.

In Argentina, the government took over the troubled airline and the private pension system in 2008. Because the pension funds had big shareholdings in many companies, the government, through the National Social Security Administration, now has the right to nominate directors to the boards of the firms, which it has done in 20 companies. The social security administration also ramped up spending on public works and the unemployed ahead of the congressional elections (Economist, February 27, 2010).

Finally, beyond directly owning SOEs, governments also hold indirect shares in companies through state-owned financial institutions and pension funds (data on this category of companies are scarce). In Brazil, for example, the state-owned oil company Petrobras raised its stake in Braskem-a private sector chemical company-by US $\$ 1.4$ billion in early 2010, while the state-owned development bank BNDES and the pension funds of big state companies have increased their holdings in many of Brazil's largest private sector firms (Economist, April 3, 2010). 


\section{SOE Performance and Impacts}

Available evidence suggests that the financial performance of many SOEs and their contribution to the state budget have improved in the past decade as a result of budgetary reforms, restructuring measures, improved governance practices, and exposure to greater competition and capital market discipline:

- In China, SOE profitability has increased since the expansion of competition, corporatization, and the creation in 2003 of the StateOwned Assets Supervision and Administration Commission to exercise authority over state enterprises. The reported average return on equity rose from 2.2 percent in 1996 to 15.7 percent in 2007, before slipping back to 10.9 percent in 2009 (World Bank and Development Research Center 2013).

- In India, the 24 largest nonfinancial SOEs generated a 17 percent return on equity in 2010, and profits almost doubled in the past five years.

- In Indonesia, following restructuring and governance improvements, SOE profits grew at a compound annual rate of 18.9 percent between 2004 and 2009, while contributions to the state budget through dividends and tax payments amounted to 12 percent of budget revenue (Abubakar 2010).

- In Malaysia a program aimed at transforming government-linked companies (GLCs), now in the seventh of the 10-year program, has helped improve performance. The return on equity of 20 larger companies rose from 7.7 percent in 2009 to 10.5 percent in 2010, while total shareholder return grew by 16.4 percent from 2004 to 2011. Indicators such as operating cash flow and debt-to-equity ratios have also improved (Putrajaya Committee 2011).

- In the Middle East and North Africa, many countries in the Persian Gulf have created profitable and well-run SOEs in strategic industries. These include the Saudi Basic Industries Corporation, Emirates Airlines, Dubal, and Etisalat, all of which have made their mark domestically and internationally (Hertog 2010; OECD 2012).

However, SOE performance is not uniformly positive. Notwithstanding performance improvements, a disproportionate share of SOE profits often comes from a few large firms that earn high rates of return through limits on competition and access to cheaper land, capital, and other inputs. Moreover, even those SOEs that are performing well often lag behind private and other nonstate firms in financial, economic, and operational performance. Compared to the private sector, many state-owned banks suffer from a 
number of vulnerabilities, including weak balance sheets and low capitalization, poor underlying profitability, and high nonperforming loans:

- In China, nonstate firms had an average return on equity 9.9 percentage points higher than that of SOEs in 2009 (World Bank and Development Research Center 2013).

- In Vietnam, although SOEs registered healthy returns on equity (17 percent), their returns were below the economy's nominal growth rate (19 percent) and well below the returns of foreign firms (27 percent). Rapid growth in the capital and fixed-asset base of SOEs has not been accompanied by higher productivity: in 2009, the average ratio of turnover to capital was 1.1 for SOEs but 21.0 for all enterprises; the ratio of turnover to employees was 1.7 for SOEs and 16.3 for all enterprises; and the ratio of turnover to fixed assets fell for SOEs between 2000 and 2008, while remaining unchanged for all enterprises (World Bank 2011).

- In Malaysia, a 2008 study showed that government-linked companies tend to score lower than private sector companies on metrics of economic performance or economic value added (measured as the difference between cash flow returns on investment and the weighted average cost of capital) (Issham et al. 2008).

- A study of nine Middle Eastern countries found that state-owned banks have much lower profitability than private banks due to their large holdings of government securities, larger ratios of overhead costs to assets (because of much larger ratios of employment to assets), and higher ratios of loan-loss provisions to outstanding loans (reflecting much larger shares of nonperforming loans in their portfolios) (Rocha 2011).

- A recent survey of 90 state-owned development banks from 61 countries shows that their financial performance is mixed; 15 percent report nonperforming loans exceeding 30 percent of their total loan portfolio, while nearly 60 percent indicate that without government budget transfers their self-sustainability is a major challenge (de Luna Martinez and Vicente 2012).

- SOEs tend to perform particularly poorly in low-income countries, although there are exceptions. A study in Burkina Faso, Mali, and Mauritania found that of the 12 SOEs that provided information, 8 reported losses while 3 were operating at close to breakeven. Only one reported significant profits: Mauritania's Société Nationale Industrielle et Minière, a mining company (Bouri, Nankobogo, and Frederick 2010).

Underperforming SOEs bring high financial and economic costs. In many countries, these enterprises remain a fiscal burden and a source of fiscal risk. In Indonesia, for example, subsidy payments to three SOEs alone-those 
producing fuel, electricity, and fertilizer-averaged 4 percent of GDP between 2003 and 2006; yet the subsidy still fell short of what was needed to cover all quasi-fiscal obligations and arrears with other SOEs (Verhoeven et al. 2008). In Vietnam, many large SOEs receive subsidies and their capital investment funds from public sources, including state banks. Their growing size and the complex cross-holdings of charter capital across and within enterprises make it difficult to assess the inherent risks involved in their activities and the contingent liabilities they give rise to. Some SOEs acquire noncore assets and companies, saddling themselves with large debt burdens. The total liabilities of SOEs exceed the government's own debt, posing a significant fiscal risk (World Bank 2011). In Vietnam, as elsewhere, the financial and fiscal risks from SOEs can spill over into the broader economy, especially if SOEs have strong links with state-owned banks.

Poor performance by SOEs can also impede competitiveness and growth. In many countries, SOEs continue to crowd out or stifle the private sector, while lack of competitive markets or a level playing field creates inefficiencies and limits the expansion of the private sector. Numerous surveys and studies show that the shortage of key infrastructure capacities, due in part to SOE inefficiencies and underinvestment, is ranked as one of the top three constraints on competitiveness and growth. One study shows that investment by many infrastructure SOEs is 50-120 percent lower (depending on the country group) than required to meet service delivery needs (Estache and Fay 2007). Achieving higher levels of economic activity will therefore require substantial improvements in the productivity and performance of existing infrastructure SOEs, along with private sector investments and public-private partnerships.

Loss-making and ineffective financial SOEs weaken the financial system as a whole, and, by lending mainly to unprofitable SOEs, they can create contingent liabilities that become a source of fiscal risk. By underpricing risks and engaging in business practices that displace commercial financial services of the private sector, financial SOEs hinder new private entry and undermine competition, which in turn retard financial market development, diminish access to financial services, and weaken the stability of the financial system (Scott 2007). Financial SOEs provide most of the financing for the great majority of enterprises and individuals, particularly in emerging markets, and weak institutions can harm economic growth and erode public trust.

The underperformance and high opportunity costs of SOEs are symptomatic of a number of underlying problems. Exogenous factors, such as shifts in commodity prices, may play a role, as do sector-specific factors such as public service obligations and regulated prices. But there is increasing recognition that poor corporate governance of SOEs is at the heart of 
the matter. Understanding the governance challenges and addressing them in the SOEs that play significant roles in an economy are thus a central concern for economic growth and financial sector development.

\section{Corporate Governance Challenges in SOEs}

Corporate governance refers to the structures and processes for the direction and control of companies. It specifies the distribution of rights and responsibilities among the company's stakeholders (including shareholders, directors, and managers) and articulates the rules and procedures for making decisions on corporate affairs (figure 1.1). Corporate governance therefore provides the structure for defining, implementing, and monitoring a company's goals and objectives and for ensuring accountability to appropriate stakeholders. Good corporate governance systems ensure that the business environment is fair and transparent, that company directors are held accountable for their actions, and that all business contracts made by the company can be enforced. A company committed to good corporate governance has strong board practices and commitment, effective internal controls, transparent disclosure, and well-defined shareholder rights.

Compared with private sector companies, SOEs face distinct governance challenges that directly affect their performance. A useful lens through which to view these differences is the classic distinction between the

FIGURE 1.1 Key Stakeholders in Corporate Governance

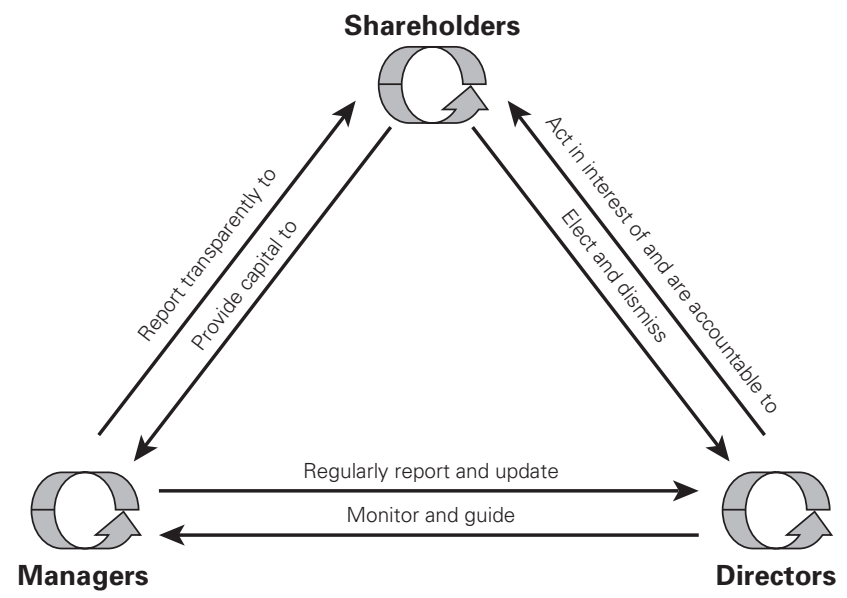

Source: IFC 2008. 
interests of a firm's owner (its principal) and its managers (the agents). In any principal-agent relationship, the principal confronts two distinct tasks: to set the goals that the agent is to pursue and to manage the moral hazard problems associated with delegation of responsibility to an agent whose private incentives are likely to differ from those of the principal.

For private companies, the goal-setting challenge is relatively straightforward: the primary goal of owners is to achieve the best financial performance. Consequently, much of the focus of private sector corporate governance is to align the incentives of managers with those of the enterprise's owners and shareholders. SOEs face the same challenge of aligning the incentives of managers and owners. However, they can encounter additional governance challenges arising from several sources:

- Multiple principals

- Multiple and often competing goals and objectives

- Protection from competition

- Politicized boards and management

- Low levels of transparency and accountability

- Weak protection of minority shareholders

\section{Multiple Principals}

The owners or principals of private companies play key roles in corporate governance. They seek to elect or appoint the best people they can find to the board of directors, set clear goals, monitor company performance, and provide capital to fund expansion. However, SOEs often lack a clearly identified principal or owner. Instead, the state frequently exercises its ownership responsibilities through multiple actors-such as line ministries, the ministry of finance, and a number of other government bodies. As a result, conflicts between the state's ownership functions and its policymaking and regulatory functions can arise and leave the company vulnerable to being used to achieve short-term political goals to the detriment of its efficiency. Moreover, in carrying out its ownership functions, states often set inconsistent goals, fail to monitor company performance closely, and cannot supply sufficient capital. In the absence of clear legal frameworks or the proper implementation of laws and regulations, the state also often assumes functions that should be carried out by the board, such as appointing and dismissing the chief executive officer and approving budgets and investment plans. This provides scope for political interference and inconsistencies in direction and approach and can open opportunities for corruption. 


\section{Multiple Goals}

While many private sector companies have the objective of increasing "shareholder value," SOEs typically have multiple and potentially competing goals. In addition to profitability, SOEs are often subject to broad mandates and public service obligations (such as providing rail, mail, or telephone service at stipulated prices) and to broader social and industrial policy goals. Some of these objectives may be explicit; others, implicit but no less important in practice. State financial institutions such as development banks and development finance institutions can also have broad and general mandates that are not well defined, providing room for government direction. When SOEs have multiple, ambiguous, or conflicting objectives, a practical consequence is that managers may aim to achieve all of the objectives and end up achieving none. Others may have substantial latitude to run the firm in their own interests. Governments may also interfere in company affairs for political gain under the cover of their different policy goals and mandates. Without clear goals, assessing managerial performance is difficult, and opportunities for political capture of the SOE and its resources are increased.

\section{Protection from Competition}

Although SOEs may be burdened with multiple objectives, they do not always operate on a level playing field with the private sector. They often receive preferential treatment through access to subsidies, bank credit, procurement contracts, and, in some cases, special tax or customs rates. Preferential treatment may give SOEs advantages that crowd out the private sector and lead to anticompetitive behavior with other market participants. Concerns about a level playing field have also grown on the international front as SOEs have expanded and become investors in ventures outside their home region or country. Perceptions about how SOEs operate-including the extent of political backing, implicit government guarantees, preferential procurement practices at home, less severe regulations, and lack of transparency-have led private sector companies (foreign and domestic) to demand that SOEs be subjected to stronger governance and transparency requirements.

\section{Politicized Boards and Management}

SOEs often lack a board of directors with the required experience and range of competencies to perform the classic corporate governance roles: to guide 
strategy, oversee management, and ensure a robust internal control system. Instead, SOE boards often represent different stakeholders, all of whom may have agendas that conflict with the interest of the company and that interfere with commercial decision making. Conversely, SOE boards may act purely as a "rubber stamp" for government decision making, exercising no oversight over managers (who in practice report directly to the government). Board members are often government employees without experience in managing companies and are appointed for political reasons rather than on the basis of technical and financial expertise. Independent directors are usually underrepresented on the board, and, where they do serve on boards, their independence is often called into question. Board-level committee structures are nascent, and board expertise in important areas such as audit and risk management remains weak in many SOEs.

\section{Little Transparency and Accountability}

Although publicly owned, many SOEs often have weak internal controls and processes, inadequate accounting and auditing practices, and weak compliance procedures, with low levels of financial and nonfinancial disclosure and few if any requirements to publicly report their accounts or other information. Many of these problems stem from the lack of a clear performance-monitoring system to ensure accountability and responsibility for performance, particularly of the board and the chief executive officer. Moreover, where such systems exist, they are often rudimentary, and aggregate reporting may not be carried out. A lack of transparency and disclosure can undermine SOE performance monitoring, limit accountability at all levels, conceal debt that can damage the financial system, and create conditions that increase the likelihood of corruption. Sectors such as extractive industries, natural resources, and infrastructure may be particularly prone to corruption risks.

\section{Weak Shareholder and Stakeholder Protection}

Many SOEs, especially listed SOEs, have minority shareholders. And like other controlling shareholders, the state may ignore minority rights, including carrying out transactions that benefit management or other SOEs at the expense of outside shareholders. Because SOEs also often have a powerful array of stakeholders, including employees, consumers, local communities, and state-owned creditors, balancing their competing interests can be a challenge. 


\section{The Benefits of Good Corporate Governance}

As the toolkit shows, a number of governments in developed and developing economies alike are taking concrete actions to address the above challenges in order to: (1) enhance the competitiveness of SOEs and the economy as a whole; (2) provide critical infrastructure, financial, and other services in a more efficient and cost-effective manner; (3) reduce the fiscal burden and fiscal risk of SOEs while improving their access to external sources of finance through the capital markets; and (4) strengthen transparency and accountability.

A good corporate governance system in general is associated with a number of benefits for all companies, private or state owned. As documented by Claessens and Yurtoglu (2012), good corporate governance leads to a number of positive outcomes:

- Better access to external finance by firms, which in turn can lead to larger investments, higher growth, and greater employment creation.

- Lower costs of capital and higher firm valuation, which make investments more attractive to investors and thus also lead to growth and more employment.

- Improved strategic decision making and operational performance, through better allocation of resources and more efficient management, which create wealth more generally.

- Reduced risk of corporate crises and scandals, a particularly important outcome given the potentially large economic and social costs of financial crises.

- Better relationships with stakeholders, which improve social and labor relationships, help address such issues as environmental protection, and can help further reduce poverty and inequality.

Many, if not all, of these benefits apply to SOEs. While few empirical studies specifically analyze the direct impacts of corporate governance on SOE performance, anecdotal evidence shows that better governance benefits both individual companies and the economy as a whole:

- Improved operational performance of SOEs. A recent study of 44 SOEs in the water and electricity sectors of countries in Latin America and the Caribbean finds a positive correlation between six dimensions of corporate governance reform and the operational performance of the utilities (Andrés, Guasch, and López Azumendi 2011). The dimensions include the legal and ownership framework, the composition of the board, the performance management system of the enterprise, the degree of transparency and disclosure of financial and nonfinancial information, 
and the characteristics of staff (for example, education, salary, and benefits). The study shows that the composite index of these dimensions is strongly correlated with labor productivity, tariffs, and service coverage.

- Increased access to alternative sources of financing through domestic and international capital markets, while helping develop markets. As governments face continued budget constraints, better-governed SOEs are more easily able to raise financing for infrastructure and other critical services through the capital markets. In turn, SOE issuances can help develop capital markets. Malaysia's government-linked companies, for example, account for about 36 percent of the market capitalization of Bursa Malaysia and about 54 percent for the benchmark Kuala Lumpur Composite Index. In India, 41 centrally owned SOEs account for 20 percent of the market capitalization of the Mumbai Stock Exchange.

- Financing for infrastructure development. Most public spending on infrastructure passes through SOEs (Akitoby, Hemming, and Schwartz 2007). By reducing internal inefficiencies, SOEs can make that spending go farther. For example, a recent study suggests that of the roughly US\$93 billion annual infrastructure investment gap in Sub-Saharan Africa (equal to 15 percent of the region's GDP), nearly US\$17 billion could come from savings produced by improving internal efficiencies through better governance and other means (Foster and BriceñoGarmeñdia 2010).

- Reduced fiscal burden of SOEs and increased net contribution to the budget through higher dividend payments. The Lithuanian government, which is working to improve the governance of its major SOEs, has estimated that annual dividends from better governance could be increased by 1 percent of GDP, helping reduce its budget deficit as part of efforts to join the Euro Area in 2014. In 2010, the Chinese government announced that it would start extracting more in dividends from its SOEs with the aim of forcing them to compete more fairly with the private sector and allocating resources to social expenditures. Improved governance also increases transparency of the contingent liabilities associated with SOEs, thereby reducing fiscal risk.

- Reduced corruption and improved transparency. Corruption remains a serious problem in SOEs and can influence the financial strength and valuations of the companies, negatively affect investor perceptions, lead to the misallocation of scarce government resources, and constrain overall economic and financial growth. Better-governed companies with integrity and accountability mechanisms are likely to be less corrupt and more transparent. 


\section{Framework for Corporate Governance Reform}

In view of the above, many countries are pursuing fundamental governance reforms to improve the relationship between the companies and the government as owner. Such reforms have focused on improving both the role and the behavior of the state as an owner and on instigating corporate governance reforms within the SOE sector. As discussed in the subsequent chapters of the toolkit, the main elements in improving the overall corporate governance framework are the following:

- Developing a sound legal and regulatory framework for SOE governance (chapter 2)

- Improving the state's ownership role (chapter 3)

- Establishing a performance monitoring system for accountability (chapter 4)

- Enhancing financial and fiscal discipline of SOEs (chapter 5)

- Professionalizing SOE boards of directors (chapter 6)

- Enhancing transparency and disclosure (chapter 7)

- Ensuring shareholder protection in mixed-ownership companies (chapter 8)

- Building support and capacity for implementation (chapter 9)

In undertaking reform of their SOEs, governments often look toward the OECD's Guidelines on Corporate Governance of State-Owned Enterprises, which serves as the international benchmark of good practice. Established in 2005, the guidelines provide a framework for assessing and improving the governance practices of SOEs that have a distinct legal form, are commercial in nature, and are controlled by the state through full, majority, or significant minority-share ownership. They cover six main areas: the legal and regulatory framework for SOEs, the role of the state as owner, equitable treatment of shareholders, relations with stakeholders, transparency and disclosure, and the responsibilities of SOE boards (box 1.3).

Governments have also sought to learn from a growing body of knowledge and the many practical reform experiences that have unfolded in recent years, both in OECD countries and in emerging market countries. These show that while many technocratic solutions are available, implementation is not an easy task. Corporate governance reforms can be politically challenging. Entrenched groups may oppose reforms or find ways to resist them. And the wide range of political and institutional circumstances in different countries, as well as differences between sectors and types of SOEs, means that there can be no one-size-fits-all approach to reform. 
BOX 1.3

\section{Summary of the OECD's Guidelines on Corporate Governance of SOEs}

- Ensuring an effective legal and regulatory framework for state-owned enterprises. To avoid market distortions, the legal and regulatory framework for SOEs should ensure a level playing field in markets where SOEs and private sector companies compete. Such a framework implies clear separation between the state's ownership function, simplified operational practices for SOEs, uniform application of general laws and regulations to all enterprises including SOEs, and no privileged access to SOEs for factors of production, including finance.

- The state acting as an owner. The state should act as an informed and active owner and establish a clear and consistent ownership policy, ensuring that the governance of SOEs is carried out in a transparent and accountable manner, with the necessary degree of professionalism and effectiveness (for example, no involvement of government in the day-to-day management of SOEs; the state should let SOE boards exercise their responsibilities and respect their independence).

- Equitable treatment of shareholders. The state and SOEs should recognize the rights of all shareholders and ensure their equitable treatment and equal access to corporate information (for example, SOEs should be highly transparent with all shareholders, develop an active policy of communication and consultation with all shareholders, and protect the rights of minority shareholders).

- Relations with stakeholders. The state ownership policy should fully recognize the SOEs' responsibilities toward stakeholders and request that they report on their relations with them (for example, large SOEs, and SOEs pursuing important public policy objectives, should report on stakeholder relations).

- Transparency and disclosure. SOEs should observe high standards of transparency such as developing consistent and aggregate reporting and an annual independent external audit based on international standards.

- Responsibilities of SOE boards. SOE boards should have the necessary authority, competencies, and objectivity to carry out their function of strategic guidance and monitoring of management. They should act with integrity and be held accountable for their actions (for example,

(box continues on next page) 
BOX 1.3 continued

SOE boards should be assigned a clear mandate, responsibility for the company's performance, and be fully accountable to the owners; they should be constituted in such a way that they can exercise objective and independent judgment).

Source: OECD 2005.

For these reasons, successful reform implementation requires that close attention be paid to the local context and to the process of reform itself. Implementation of the corporate governance framework as a whole can be a daunting task for both governments and SOEs, especially in low-income settings where institutional and financial capacity are limited. Finding the right entry points for change and adopting a flexible, step-by-step approach for improving corporate governance will be required. The pace and sequencing of reforms will need to be calibrated to the economic, political, and institutional realties on the ground, as well as to the needs of individual enterprises. As the rest of the toolkit shows, reform is also a long-term process that requires constant attention to building political will, mobilizing public support, and strengthening implementation capacity.

\section{Notes}

1. Comparing the performance of state and nonstate enterprises is not straightforward, as the former often pursue a multiplicity of goals-including equity and service coverage-and not only profit maximization. Moreover, as noted in chapter 2, SOEs are often faced with disadvantages such as those related to labor market rigidities.

2. Early privatization efforts were concentrated in Latin America and the formerly centrally planned economies of Eastern and Central Europe. In Eastern and Central Europe, tens of thousands of small and medium enterprises were transferred to the private sector through voucher privatization.

3. A systematic inventory of SOEs worldwide by size, type, and economic weight is lacking. Many countries do not have centralized bodies that track SOEs as a whole or produce consolidated SOE reports. Where such data exist, they are often outdated or incomplete. These constraints are especially severe in low-income countries with little capacity to collect and analyze data.

4. The survey covers SOEs at the federal level, including publicly listed SOEs with majority or minority ownership, unlisted SOEs, statutory corporations, and quasi-corporations. Missing from the survey are such countries as Japan, Turkey, and the United States, which also have substantial SOE sectors. 


\section{References}

Abubakar, Ir. Mustafa. 2010. "Ministry of State-Owned Enterprises, Indonesia: Towards World Class Corporations.” PowerPoint presentation.

Akitoby, Bernardin, Richard Hemming, and Gerd Schwartz. 2007. Public Investment and Public Private Partnerships. Economic Issues 40. Washington, DC: International Monetary Fund.

Andrés, Luis Alberto, Jose Luis Guasch, and Sebastian Lopez Azumendi. 2011. "Governance in State-Owned Enterprises Revisited: The Cases of Water and Electricity in Latin America and the Caribbean." Policy Research Working Paper 5747, World Bank, Washington, DC.

Bouri, Mazen, Francois Nankobogo, and Richard Frederick. 2010. "Synthesis Review of Corporate Governance of State-Owned Enterprises in Burkina Faso, Mali, and Mauritania." Africa Region Working Paper 131, World Bank, Washington, DC.

Claessens, Stijn, and Burcin Yurtoglu. 2012. "Corporate Governance and Development: An Update.” Global Corporate Governance Forum Focus 10 (rev.), International Finance Corporation, Washington, DC. http://www.ifc.org/wps /wcm/connect/518e9e804a70d9ed942ad6e6e3180238/Focus10 _CG\%26Development.pdf?MOD=AJPERES.

de Luna-Martinez, Jose, and Carlos Leonardo Vicente. 2012. "Global Survey of Development Banks.” Policy Research Working Paper 5969, World Bank, Washington DC.

Economist. 2010. “The Growth of the State.” January 23.

—. 2010. "Socialism for Foes, Capitalism for Friends.” February 27.

_. 2010. "Falling in Love Again with the State." April 3.

_. 2010. "A Special Report on Banking in Emerging Markets." May 15.

Estache, Antonio, and Marianne Fay. 2007. "Current Debates on Infrastructure Policy." Policy Research Working Paper 4410, World Bank. Washington, DC.

Foster, Vivien, and Cecilia Briceno-Garmendia, eds. 2010. "Overview." In Africa's Infrastructure: A Time for Transformation. Washington, DC: World Bank.

Hertog, Steffen. 2010. "Defying the Resource Curse: Explaining Successful StateOwned Enterprises in Rentier States." World Politics 62 (2): 261-301.

IFC (International Finance Corporation). 2008. Corporate Governance Board Leadership Training Resources Kit. Washington, DC: IFC.

Issham, Ismail, Abdul Samad M Fazilah, Yen Siew Hwa, Anton Abdulbasah Kamil, and Azli Azli Ayubh, and Meor Azli Ayubh. 2008. "Economic Value Added (EVA) as a Performance Measurement for GLCs vs Non-GLCs: Evidence from Bursa Malaysia." Prague Economic Papers 3. http://www.vse.cz/pep/abstrakt .php3?IDcl=328.

Kikeri, Sunita, and Verena Phipps. 2008. "Privatization Trends: A Record Year for Initial Public Offerings in 2007.” Note 321, Financial and Private Sector Vice Presidency, World Bank, Washington, DC. 
Kikeri, Sunita, and Amit Burman. 2007. "Privatization Trends: Near-Record Levels in 2005.” Note 314, Financial and Private Sector Vice Presidency, World Bank, Washington, DC.

Kikeri, Sunita, and Aishetu Kolo. 2006. "State Enterprises: What Remains?" Note 304, Public Policy for the Private Sector, World Bank, Washington, DC.

Kikeri, Sunita, and John Nellis. 2004. "An Assessment of Privatization.” World Bank Research Observer 19 (1): 87-118.

Kikeri, Sunita, John Nellis, and Mary Shirley. 1992. Privatization: The Lessons of Experience. Washington, DC: World Bank.

Nellis, John. 2011. "The International Experience with Privatization: Its Rapid Rise, Partial Fall and Uncertain Future.” Draft. Calgary Privatization Paper.

Nellis, John, and Nancy Birdsall. 2005. Reality Check: The Distributional Impact of Privatization in Developing Countries. Washington, DC: Center for Global Development.

OECD (Organisation for Economic Co-operation and Development). 2005. OECD Guidelines on Corporate Governance of State-Owned Companies. Paris: OECD.

_. 2009. "State-Owned Enterprises in India: Reviewing the Evidence." Occasional Paper, Working Group on Privatization and Corporate Governance of State-Owned Assets, OECD, Paris.

- 2011. "The Size and Composition of the SOE Sector in OECD Countries." OECD Corporate Governance Working Paper 5, OECD, Paris. http://www.oecd .org/daf/coporateaffairs/wp.

—. 2012. Towards New Arrangements for State Ownership in the Middle East and North Africa. Paris: OECD.

Putrajaya Committee on GLC High Performance. 2011. "GLC Transformation Programme: Progress Review 2011.” Kuala Lumpur.

Robinett, David. 2006. "Held by the Visible Hand: The Challenge of SOE Corporate Governance for Emerging Markets.” Working Paper 37711, World Bank, Washington, DC.

Rocha, Roberto R. 2011. Financial Access and Stability for the MENA Region: A Roadmap. Washington, DC: World Bank.

Scott, David. 2007. "Strengthening the Governance and Performance of StateOwned Financial Institutions.” Research Working Paper 4321, World Bank, Washington, DC.

Sprenger, Carsten. 2008. "The Role of State-Owned Enterprises in the Russian Economy." Paper prepared for OECD Roundtable on Corporate Governance of SOEs, OECD, Paris, October 27.

UNCTAD (United Nations Conference on Trade and Development). 2007. World Investment Report 2007: Transnational Corporations, Extractive Industries and Development. Geneva: UNCTAD.

Verhoeven, Marjin, Eric Le Borgne, Paulo Medas, and Leroy P. Jones. 2008. "Indonesia: Assessing Fiscal Risk from State-Owned Enterprises." Fiscal Department, International Monetary Fund, Washington, DC.

World Bank. 2011. "Vietnam Development Report 2012: Market Economy for a Middle-Income Vietnam.” Joint Donor Report to the Vietnam Consultative 
Group Meeting, World Bank, Washington, DC, http://web.worldbank.org /WBSITE/EXTERNAL/COUNTRIES/EASTASIAPACIFICEXT /VIETNAMEXTN/0,,contentMDK:22416790 pagePK:1497618 piPK:217854 theSitePK:387565,00.html.

- 2012. Rethinking the Role of the State in Finance: Global Financial Development Report 2013. Washington, DC: World Bank.

World Bank and Development Research Center of the State Council. 2013. China 2030: Building a Modern, Harmonious, and Creative Society. Washington, DC: World Bank and Development Research Center. 



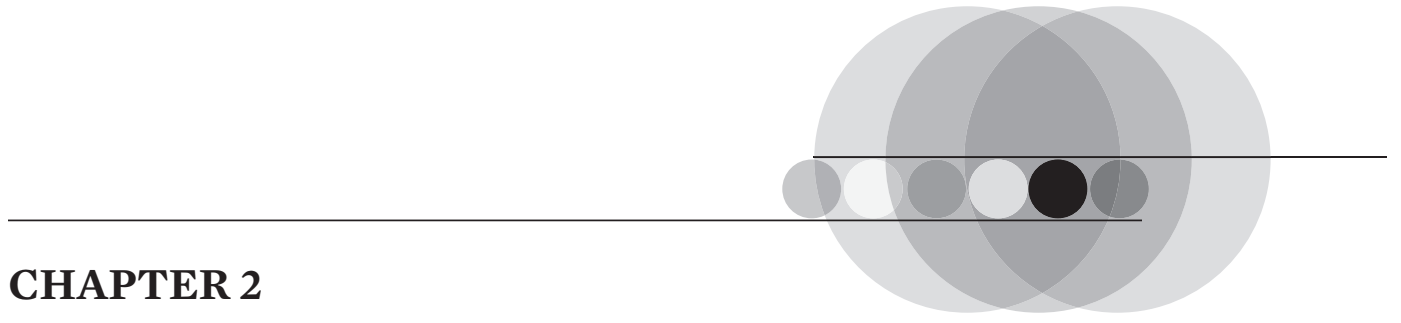

\section{Legal and Regulatory Framework}

A clearly defined legal and regulatory framework for state-owned enterprises (SOEs) is essential for communicating key expectations to SOE shareholders, boards, management, and all other stakeholders, including the general public. The underlying aim of such a framework is to make the broad policy directions of the state and the "rules of the game" clear for everyone. While no one-size-fits-all approach applies to all countries and contexts, the framework should set clear boundaries and define the relationship between the government as shareholder and SOE boards and management, separating legitimate government control and oversight for ensuring SOE accountability from the managerial autonomy necessary in commercial decision making.

This chapter describes various SOE legal forms and frameworks and the steps that governments are taking to improve and modernize their legal frameworks. It covers the following topics:

- Overview of SOE legal forms and frameworks

- Key issues in the legal framework

- Harmonization of SOE frameworks with private sector frameworks

- Development of a state ownership framework for SOEs. 


\section{Key Concepts and Definitions}

The SOE sector in any given country can be broadly defined. It includes SOEs that are government owned or controlled and that generate the bulk of their revenues from selling goods and services on a commercial basis, even though they may be required to pursue specific policy goals or public service objectives at the same time. ${ }^{1}$ Such SOEs are the focus of this particular toolkit. SOEs are distinguished from public agencies, quasi-governmental organizations, or other parastatal organizations in the broader state enterprise sector that carry out public policy functions at arms' length from government line departments and earn a significant share of their own revenues. ${ }^{2}$ The definitional range with respect to SOEs is reflected in the three separate descriptions prepared by the Organisation for Economic Co-operation and Development (OECD), European Union (EU), and the Republic of Korea (see box 2.1).

BOX 2.1

\section{Varied Definitions of SOEs and the Parastatal Sector}

- The OECD's Guidelines on Corporate Governance of State-Owned Enterprises. The guidelines focus on public entities that use "a distinct legal form (i.e. separate from the public administration) and [that have]... a commercial activity (i.e. with the bulk of their income coming from sales and fees), whether or not they pursue a policy objective as well. These SOEs may be in competitive or in non-competitive sectors of the economy. When necessary, the Guidelines distinguish between listed and non-listed SOEs, or between wholly, majority or minority owned SOEs since the corporate governance issues are somewhat different in each case.... [The guidelines] are also useful for noncommercial SOEs fulfilling essentially special public policy purposes, whether or not in corporate form....[The term SOEs refers]... to enterprises where the state has significant control, through full, majority or significant minority ownership" (OECD 2005).

- European Union. The EC directive No 80/723 defines a public enterprise (the term used is undertaking) as "any undertaking over which the public authorities may exercise directly or indirectly a dominant influence by virtue of their ownership of it, their financial participation therein, or the rules which govern it." Under the landmark case of 
BOX 2.1 continued

Höfner and Elser, the European Court of Justice defined the concept of undertaking (that is, enterprise), as encompassing "every entity engaged in an economic activity, regardless of the legal status of the entity and the way in which it is financed." Thus, under the EU's functional definition even entities that are not legally separate from the state can be deemed an SOE. The central question then becomes how to distinguish between economic and noneconomic activities.

- Korea. The Korean Public Entity Management Act (2007) applies a two-pronged approach, first defining public institutions and then distinguishing among them based on quantitative criteria. Under the 2007 act, (1) a public entity is established by law and has received a financial contribution from government; or (2) more than half its revenue comes from government assistance; or (3) the government holds more than 50 percent of the shares of the entity (or 30 percent and maintains de facto control). Next, the Korean legal framework classifies a public entity as an SOE if it has more than 50 employees and generates at least 50 percent of its total revenues from its own activities. If its own revenue surpasses 85 percent of total revenues, then the $\mathrm{SOE}$ is further classified as a "commercial SOE." (Anything less is a "semi-commercial" SOE.)

Where SOEs are concerned, the legal framework varies greatly across jurisdictions, as well as within the same jurisdiction depending on the legal form of the enterprise. Some SOEs are established as statutory corporations with their own legislative act or other distinct legal foundation. Others may be noncorporatized entities in the form of SOEs or government departments, which usually fall under an SOE or public enterprise law. SOEs that are corporatized typically take the form of joint-stock companies or limitedliability companies and may fall under SOE law, company law, or, in some cases, both. These varying SOE legal forms and frameworks present a challenge but make it all the more important to establish a clear and suitable legal and regulatory framework for SOE governance.

The legal basis for corporate governance in most countries is found in company legislation, which in many countries applies to corporatized SOEs. Company law lays out basic shareholder rights and board and disclosure requirements, often supplemented by legal requirements for accounting and auditing and standards and professional rules for listing and other capital 
market requirements. While many governance practices are mandatory under the law, in certain instances they may be contained in a nonbinding corporate governance code, where the company is simply required to explain the reasons for the lack of compliance with the recommendations in the code ("comply or explain").

Unlike listed companies, which have shares listed on a stock exchange and are subject to the legal and regulatory structure of the capital markets, unlisted companies tend to have simpler ownership structures and stakeholder arrangements and therefore simpler corporate governance requirements. Banks and other financial institutions usually have additional (and somewhat different) legal and regulatory requirements beyond those for listed companies, such as those applying to risk management and internal controls.

\section{Overview of SOE Legal Forms and Frameworks}

As noted above, SOEs come in many different legal forms and typically reside at the intersection of public and private law, with significant variation between and within countries. SOE legal frameworks range from a fullfledged application of public law to a private law framework or a mixed approach that places some SOEs under public law, others under private corporate law, and still others under both. In a few cases, constitutional and supranational law may both apply (box 2.2).

In some cases, an individual SOE may be set up as a statutory corporation established by an act of parliament and governed by its own special statute that gives it financial independence or certain special powers (for example, authority to collect specific fees). Often such SOEs are legally assigned a specific policy goal or tasks other than profit maximization. Such SOEs are typically wholly state owned and operate in sectors where public authorities are most directly involved, such as the supply of public services or utilities.

More typically, SOEs are in the form of public enterprises that may or may not be corporatized. In addition to their enabling legislation or articles of association, such SOEs may operate under a general public enterprise or SOE law (box 2.3), or regulatory requirements may be scattered in various decrees and regulations without any overarching law. General SOE laws aim to bring uniformity to SOEs as a whole and have been developed for a variety of reasons, including to ensure that these enterprises carry out specific objectives or meet social considerations, to provide greater flexibility and managerial independence to SOEs, to reduce direct administrative management by the state, to fund the operations of the public services by fees directly collected 
BOX 2.2

\section{Application of Constitutional and Supranational Law}

National constitutions influence the role of companies, including SOEs, throughout a country and may significantly affect the subsidiary legislation that constitutes the legal framework under which SOEs operate. For example, in South Africa the 1996 constitution (section 27) confers a constitutional right to water, heightening the responsibility of government to deliver a universal service that can be limited only for compelling or urgent reasons. The 1998 National Water Act creates a comprehensive legal framework for the management of water resources, which is the responsibility of the government (see Gowlland-Gualtieri 2007 for a fuller discussion). Similar provisions exist in the constitution of Uruguay (Article 47), which includes the right to potable water and sanitation. Examples of other countries with a constitutionally recognized right to water include Ecuador, Ethiopia, Gambia, Uganda, and Zambia.

Supranational rules are an additional factor affecting the legal treatment of SOEs. For example, EU treaty obligations have effected SOE governance through the application of competition law in EU member states, particularly in sectors traditionally dominated by national monopolies (Albert and Buisson 2002). The Treaty on the Functioning of the European Union declares that "Member States shall adjust any State monopolies of a commercial character so as to ensure that no discrimination regarding the conditions under which goods are procured and marketed exists between nationals of Member States" (Art. 37; 91). Under the weight of EU competition law, most French SOEs, for example, are now regulated by the general company law rather than as individual public law entities (Établissement Public Industriel et Commercial). Provisions of the Treaty on the Functioning of the European Union, and their interpretation by EU courts, have driven the transformation of the public sector in EU member states. For a number of countries outside the EU, multilateral trade liberalization has lessened the influence of the state in SOE operations, even in countries where the political culture is supportive of state intervention for economic development. 
BOX 2.3

\section{Countries with General Public Enterprise or SOE Laws}

Some countries have general SOE framework laws. While some laws cover all SOEs, others exclude large strategic SOEs such as utilities, natural resources, and defense, which may have their own separate laws:

- The Arab Republic of Egypt, where commercial SOEs fall under the Public Business Sector Law, and where under the law SOEs are also subject to the company law. Utilities and defense SOEs, however, have their own separate laws.

- Korea, where the government-owned companies and governmentinvested companies are all subject to the Act on the Management of Public Institutions.

- Serbia, where nonincorporated SOEs operate under the Law on Public Enterprises and where such SOEs are also subject to the company law.

- Turkey, where the bulk of national SOEs, including corporatized and noncorporatized SOEs, operate under Decree Law 233 on SOEs, while others have their own establishment acts or fall under the Privatization Law.

from users and not solely through taxes, to link staff and users more closely to the delivery of a public service, and to provide for the dedication of expenses and revenues when a service is performed directly by the state as a legal person. SOE laws typically define the legal structure of SOEs, their administration, and the role of governing bodies such as boards and general assemblies (specific regulatory provisions with respect to these areas are covered in greater detail in the subsequent chapters of the toolkit).

In many countries, incorporated SOEs in the form of joint-stock companies or limited-liability companies are regulated by normal company legislation. ${ }^{3}$ In addition to company legislation, they may also be regulated by their own enabling legislation, by a general SOE law, or by SOE ownership policies, guidelines, and codes of corporate governance. Box 2.4 provides examples of countries where SOEs operate under company legislation or under SOE legislation as well. Where SOEs are listed on the stock exchange, they are also subject to the listing requirements of the exchange and to other securities laws.

In addition to SOE laws and company legislation, SOEs are also often subject to many other public sector laws and regulations. While these vary 
BOX 2.4

\section{Countries with SOEs under Company Legislation}

Corporatized SOEs operate under normal company legislation in many countries and sometimes under both company law and SOE law:

- Bhutan, where SOEs operate under the company law and must also abide by the SOE ownership policy that is in place.

- Chile, where company law applies to all SOEs except for nine large SOEs that have their own separate laws.

- Ghana and Kenya, where SOEs are governed mainly by company law.

- India, where SOEs fall under company law but must also follow the many different guidelines established for SOEs as well as a corporate governance code for SOEs.

- Malaysia, where government-linked corporations (GLCs) are governed by company law with the GLC Transformation Program and the GLC Transformation Manual in place.

- Pakistan, where SOEs are regulated by the Companies' Ordinance and by recently issued Rules on Corporate Governance for SOEs.

- Peru, where SOEs fall under both company law and an SOE law that creates the state ownership entity FONAFE, with a corporate governance code in place for SOEs.

- Serbia, where corporatized SOEs fall under the new company law.

- South Africa, where SOEs operate under company law with the Protocol for Corporate Governance in place.

- Zambia, where most SOEs are legally founded under the Companies Act.

from one country to the next, and within countries by type of SOE, they often include public sector employment rules, investment and budgeting regulations, public sector procurement laws, public financial management laws, public sector audit requirements, and sector-specific laws and regulations.

\section{Key Issues in the SOE Legal Framework}

In many countries, public enterprise or SOE laws are outdated and came into effect at a time when SOEs operated as vertically integrated enterprises with very little competition in the market. Many such laws have overlapping 
and sometimes contradictory provisions that lead to inconsistent and conflicting frameworks and undermine the accountability of the state, boards of directors, and management. While the original intent may have been to put SOEs on a commercial footing and foster greater enterprise autonomy, instead they have often had unintended consequences:

- They may give powers and responsibilities to government owners that weaken the board of directors, such as the responsibility for setting company strategy or appointing the chief executive.

- They may require SOEs to be profitable and at the same time to carry out social objectives without any provisions for financing the costs of meeting those objectives.

- They may impose restrictions that reduce the operational autonomy of SOEs in key areas, such as budgeting, investments, pricing, and human resources.

- They may limit the means for altering the capital structure of SOEs or call for lengthy approval processes for budgets and investments that delay decision making.

- They may contain weak corporate governance provisions in areas such as boards, preferred rights, and disclosure.

- They may not stipulate how the state should behave as an owner or as a shareholder: for example, how it should vote its shares; how it should appoint, recall, and remunerate boards and management; and how it should monitor the companies.

- They may override general company law.

Shortcomings also arise when SOEs operate under private company law, especially in the absence of a proper framework that governs the state's role as owner and its relations with SOEs:

- In the absence of a clear framework for board nominations, SOE boards may be composed of members, including government officials and sometimes ministers, who lack the necessary qualifications, skills, and experience for the job.

- SOEs may be responsible for social and policy obligations but without specific identification and adequate compensation for the provision of such services.

- Without a properly defined monitoring system, unsupervised SOEs may incur significant debts and acquire noncore assets, creating a source of financial and fiscal risk.

For these reasons, many countries are revamping and modernizing their legal and regulatory framework to create a strong foundation for improving 
SOE governance and performance. Experience from a number of countries highlights two important steps in that effort: harmonizing SOE frameworks with private sector frameworks and improving or developing a clearly defined state ownership framework.

\section{Harmonizing SOE Frameworks with Private Sector Frameworks}

More and more countries are treating commercial SOEs just like other companies and are taking steps to harmonize their corporate governance frameworks with modern governance rules applicable to private companies. Unlike private companies, however, many SOEs, especially those providing public services and supporting other public policy goals, have to balance commercial and noncommercial objectives. Such SOEs are often explicitly established to carry out public service obligations, even though they operate in competitive markets. For such SOEs, additional measures (as discussed in greater detail in chapter 5) are required as part of a state ownership framework to ensure that noncommercial obligations are properly identified, compensated, and carried out in a transparent manner.

Eliminating or reducing differences between the rules governing SOEs and other companies aims to give companies greater operational flexibility and insulate them from political interference; to subject SOEs to the same corporate governance discipline as private firms, such as in financial reporting and disclosure; and to commit SOEs to improving their governance. Another important objective is to ensure that SOEs operate on a level playing field with the private sector. Creating a level playing field means ensuring that SOEs have neither an advantage nor a disadvantage on account of their ownership compared to private companies in the same market. It also requires that the participation of SOEs in economic activities not distort competition in the market. In OECD countries, competitive neutrality is the term applied to subjecting SOEs to the same laws and regulations as private firms, which is a key characteristic of a level playing field. Another important aspect is financial and fiscal discipline, which is covered separately in chapter 5 .

The objectives above have led a number of countries to put SOEs on the same legal footing as the private sector to make them more commercially oriented and competitive. Important steps in the process include applying company legislation to SOEs, ensuring equal application of broader laws and regulations to both state and private sectors, and subjecting SOEs to capital market laws by listing them on the stock exchange. 


\section{Application of Company Legislation to SOEs}

In many countries, SOEs are already operating under normal company legislation, while others are increasingly moving in that direction. Applying normal company legislation to corporatized SOEs is a relatively easy step. But bringing noncorporatized SOEs under the company law first requires a process of corporatization. Corporatization is the act of reorganizing an SOE into a legal entity with corporate structures similar to other companies, including a board of directors, management, and shareholders. The main goal of corporatization is to allow the government to retain ownership but still enable it to run SOEs efficiently and on a more commercial basis like other companies.

Larger SOEs typically take the form of a joint-stock company, while smaller SOEs may be organized in the form of limited-liability companies. The process of transforming or corporatizing an SOE into a separate legal entity with a company form varies across countries and within countries by type of SOE, but a few guiding steps can be mentioned:

- Determine if separate legislation is needed to change the status or ownership of SOEs, especially in the case of those established by a specific law. Some SOEs may be subject to specific legislation that may require statutory reforms.

- Determine the company's mission and mandate.

- Define the government shareholding clearly.

- Identify noncommercial objectives and determine how to handle them. In some cases, they have been abandoned, while in others they have been costed out and financed separately (chapter 5).

- Identify and value the company's moveable and fixed assets.

- Prepare balance sheets to determine the equity value of the company.

- Establish the reporting relationship to the shareholder.

- Determine the corporate governance structures of the company.

- Carry out internal reorganization and restructuring as required.

- Transfer assets and employees.

- Register the company in the company registry.

The state can be the sole shareholder or the majority shareholder in corporatized companies. In such cases, it exercises control over the SOEs by appointing the board of directors, voting its shares, and monitoring and reporting on SOE performance. In companies where the state owns minority shares, the state may exercise control through shareholder agreements or special legal provisions such as a "golden share" (chapter 8 covers issues related to minority state ownership in greater detail). A golden share refers to a special provision by which the state maintains a veto over corporate 
decisions by holding onto special rights, notably through preferred stock holding retained by the state after privatization. Golden shares, however, are declining in use. For example, they were deemed illegal by European Union courts in 2000 and reconfirmed several times since.

Corporatization and the accompanying change in legal status are intended to reduce government interference, clarify SOE goals, provide operational flexibility, and bring better and more flexible governance standards and practices to SOEs. The goal is to move SOEs toward greater profitability and efficiency:

- A study of 25 Canadian SOEs examined the impact of corporatization on performance, covering the period 1976 to 1999 when corporatization took place. Performance is measured through a multicriteria approach, including indicators of profitability (return on sales and return on assets) and productivity (sales per employee, earnings before interest and taxes per employee, and asset turnover). The results suggest that corporatization had a significantly positive impact on the financial performance of SOEs. These effects are often perceptible as early as four years after revision of the firm's mandate, with difference in performance caused by a fundamental difference in the firms' objectives. Large SOEs performed better as they are better positioned to realize economies of scale. The main caveat involves the status of the SOEs, as they are often in monopolistic or oligopolistic sectors, which may make them profitable despite their special set of objectives and make comparisons with private firms difficult (Bozec and Breton 2003).

- A study using survey data from 442 Chinese SOEs over the period 1990-99 shows that corporatized SOEs performed better than noncorporatized SOEs in the sample (Aivazian, Ge, and Qui 2005). Improvements in profitability and efficiency are attributed to better monitoring of managers, better information-sharing channels, and less government interference. Unlike noncorporatized SOEs, corporatized firms set up a board of directors and chief executive officer (CEO) per the Corporate Law, as well as independent legal, financial, and marketing departments. The study also found that the influence of the Communist Party in selecting managers is weaker in corporatized firms than in noncorporatized firms (although the study shows that in most cases it was the government that issued the appointment letter, not the board as good practice dictates). It also found that corporatization did not fully instill financial discipline, with corporatized firms borrowing from state banks more than noncorporatized firms, and that there is significant room to reduce infringement on managerial autonomy even further. 
However, experience also shows that corporatizing SOEs and bringing them under company law may achieve little in the absence of parallel corporate governance reforms as covered in the rest of this toolkit. For example, corporatization by itself may not eliminate SOEs' protection from competition or subsidies. Board appointments may not be merit based. SOE managers may be government officials with salaries and job security on par with the public sector. And SOE performance may not be properly monitored. To achieve maximum results, the change of an SOE from a public entity to a corporate form must therefore be accompanied by the other reforms, as discussed in the rest of this toolkit.

\section{Equal Application of Other Laws and Regulations}

Equal application of broader laws and regulations helps create a level playing field and achieve competitive neutrality between state and nonstate companies so that "no business entity is advantaged (or disadvantaged) solely because of its ownership" [emphasis in the original] (Capobianco and Christiansen 2011, 3). It also aims to ensure that the participation of SOEs in all kinds of economic activities does not distort competition in the market.

When SOEs compete with private firms in markets for goods and services, the application of all laws and regulations equally to SOEs and the private sector becomes important for leveling the playing field. Yet, SOEs are often exempt from certain laws, such as competition and bankruptcy laws, and that exemption creates market distortions and reduces management accountability. At the same time, the imposition of other public sector laws and regulations on SOEs, such as human resource regulations and procurement regulations, can undermine their ability to compete. Apart from legal and regulatory barriers, an uneven playing field can also arise from financial and fiscal policies that give SOEs access to so-called soft budget constraints or require them to carry out public service obligations without adequate compensation (covered in chapter 5).

Competition Law. With the dismantling of monopolies, SOEs frequently compete with private firms in markets of goods and services, and this requires the application of competition law to offset the advantages that SOEs may enjoy:

- Outright subsidization, in the form of favorable tax regimes or exemptions (such as from customs duties, social security payments, or environmental standards) or in-kind benefits such as land-use rights and rights of 
way at below-market prices, along with concessionary financing and guarantees-that is, situations in which SOEs enjoy borrowing directly from the government or from state-owned or state-controlled financial institutions at below-market interest rates.

- Preferential treatment by the state, in the form of loose regulatory regimes containing exemptions from antitrust regulations, building permits, or zoning regulations; favorable tax treatment; more lax corporate governance requirements than private firms; and preferences to SOEs in public procurement.

- Monopolies and advantages of incumbency (for example, in postal services, utilities, and the like).

- Captive equity, resulting from the nontransferability of SOEs' equity, which implies that SOEs are relatively impervious to the forces of capital markets, which could lead to hostile takeovers, for instance. If SOEs are less constrained to generate dividends, they can more easily engage in exclusionary pricing strategies.

To offset these advantages, effective neutrality may be achieved through different regulatory pathways. For example, within the EU, competition law includes antimonopoly rules and limitations on state aid (which restrict injections of capital and grants), tax holidays, and reductions in social security costs and warranties. Under Article 87 of the EU Treaty, "Any aid granted by a Member State or through State resources in any form whatsoever which distorts or threatens to distort competition by favoring certain undertakings or the production of certain goods shall, insofar as it affects trade between Member States, be incompatible with the common market." The EU Treaty also gives enforcement powers to the European Commission, which can require member states to apply competition rules to SOEs and even take measures directed at the SOEs that infringe these rules. Another implication of extending competition rules to SOEs is that these enterprises are then subject to sectoral regulators (for example, banking, insurance, electricity, telecommunications, and the like), which impose fair treatment of all competitors. ${ }^{4}$

Australia has adopted a policy not based strictly on competition law but on competitive neutrality guidelines backed by complaint units established within the Treasury, the National Competition Council, and the Independent Productivity Commission. The policy requires companies subject to competitive neutrality to have cost structures based on tax neutrality, debt neutrality, regulatory neutrality, rate of return, and costing of shared resources. Other legal tools frequently employed to promote competitive neutrality include merger control rules that carefully 
scrutinize transactions involving foreign government-controlled entities. If a merger or acquisition is likely to produce a detrimental effect on consumers (higher prices, lower quality, or less choice) or to increase market concentration in a way that could permit price-fixing agreements among market participants, the competition authorities can block the transaction unless the parties offer sufficient safeguards and remedies such as divestiture commitments or a grant of access to key infrastructure or network technologies and the like. ${ }^{5}$

Bankruptcy Law. Many SOE laws contain no provisions for bankruptcy or may exempt SOEs from general insolvency rules, giving them an advantage over private companies. Although in more and more countries, particularly in the OECD, SOEs are subject to insolvency laws, they may still remain subject to special laws (as in Poland). Alternatively, they may not be subject to the application of insolvency and bankruptcy procedures but have specific systems in place for the protection from creditors of the SOE assets used to further public service (as in Belgium and Turkey). The international standard on insolvency, embodied in the World Bank Principles for Effective Insolvency and Creditor/Debtor Regimes, recommends that state-owned enterprises be subject to general insolvency law. ${ }^{6}$ It also recommends that exceptions to this general rule be clearly stated in legislation.

Labor Law. SOEs fall under a wide variety of labor regulation, from the full application of the civil service regime to the application of private sector labor law. Hybrid regimes combine aspects of both. With corporatization, SOE labor legislation often becomes aligned with the general labor law regime, but many results are possible, as the example of France shows (box 2.5).

In general, however, SOEs face a number of labor restrictions that reduce their operational autonomy and disadvantage them vis-à-vis the private sector. In many if not most countries, SOEs' limited flexibility to hire employees or to pay market salaries restricts their ability to attract and retain talent, especially for board membership and senior management positions. In addition, SOE employees are often protected from dismissal to a greater degree than their private sector counterparts. This often leads to overstaffing and reduced labor productivity.

Some countries apply private labor laws to SOEs to enable them to attract and retain higher-level technical and managerial positions, particularly where government pay scales for those positions are considerably lower 
BOX 2.5

\section{Employee Outcomes during Corporatization in France}

During the corporatization process in France, four different outcomes took place for SOE employees:

- The legal instrument organizing the transformation of the SOE may provide a transition period during which the employees may decide to accept the employment contract proposed by the new entity (regulated by general private labor law) or keep certain rights derived from their original status. All new hires are subject to the general private labor law (for example, corporatization of the Groupement Industriel des Armées Terrestres in 1989).

- If a new entity is created, the usual outcome is the immediate application of the general private labor law to all employees (for example, when the French Atomic Energy Commission was broken up to separate the regulatory and production activities, a new national company, Compagnie générale des matières nucléaires, was created).

- The contracts of workers subject to public law may be assigned without modification to the new entity, and the workers must accept those terms (such as those affecting salaries, leaves of absence, rights to retirement, work weeks, and the like). If the employee refuses the assignment, termination of the employment relationship is regulated by public law.

- When employees are civil servants at the time of the corporatization, the transferred employees may remain under the same regime until they retire (as when France Telecom was privatized). In the case of France Telecom, a law was adopted by Parliament in 2003 allowing the 104,000 civil servants still working at France Telecom at that time to retain civil servant status in the company until their retirement.

Source: Berne and Pogorel 2004.

than the private sector. Accurate comparisons between SOEs and private companies need to consider full compensation packages to determine the competitiveness of SOE pay structures, especially since the private sector typically provides fewer benefits and nonwage rewards such as greater job security and more generous retirement benefits. 
Others are moving toward a more neutral position on dismissal rules. In Brazil, for example, the Supreme Court ruled that SOE employees are not protected by civil service labor rules and could therefore be laid off; only those hired prior to 1988 were grandfathered in and are thus protected from layoffs (Cordeiro 2007). Staffing may need to be reduced as part of broader reform programs aimed at improving performance; but SOE layoffs may be difficult in practice even when permitted by the legal framework. The World Bank's Labor Issues in Infrastructure Reform Toolkit (World Bank 2004) ${ }^{7}$ sets forth a menu of approaches and options that can be used for SOE labor restructuring.

The process of aligning public with private sector labor law is not without tensions and trade-offs, however. A gradual process may be warranted. New Zealand Rail provides one example where, through a number of stages, employment practices were progressively brought into line with private sector norms (see box 2.6).

BOX 2.6

New Zealand Rail: From Civil Servants to Private Employees

The status of workers in the New Zealand rail sector has changed several times. In 1982, New Zealand Rail was converted from a departmental enterprise in which workers had civil servant status to a statutory corporation (New Zealand Rail Corporation, or NZRC) in which workers were public servants. In 1990, the entity converted from a statutory corporation to a public limited-liability company; staff continued to be public servants. Finally, in 1993, shares of New Zealand Rail Ltd. were sold to private interests. The employees' status then changed from public sector employee to private sector employee. There were also changes in the labor contracts. Until 1986, employees of NZRC served under the central civil service conditions of employment. In 1987, NZRC came under the legislation applicable to SOEs, which made NZRC independently responsible for bargaining over its own labor relations contract. Several key changes followed:

- Simplification of the collective labor-government agreement and removal of artificial distinctions among job categories.

- Removal of the state service seniority and appeals system for the appointments and promotions process. 
BOX 2.6 continued

- Removal of senior management from the collective bargaining agreements to individual contracts with incentive-based performance measures.

- Simplification of the allowance structure and an increase in the base pay to absorb some of the allowances as well as the introduction of incentive-based compensation to most of the white-collar employees.

Nevertheless, the contract still retained many aspects of the state sector model in respect to work hours, overtime payments, and penalty payments. Following privatization in 1993, however, a privately owned company was able to make further changes to the labor contract: (1) more flexible work hours, including overtime after 80 hours each fortnight instead of after eight hours per day, were instituted; (2) fewer penalties on work outside the conventional eight-hour day, Monday to Friday, were imposed; (3) a change from one collective contract to five contracts was accomplished; and (4) no weekend or night work penalty payments for new employees were permitted.

A lump-sum payment was also made to those workers who lost out from the changes to the overtime, penalty, and allowance payments.

Source: World Bank 2004.

Procurement Law. SOEs in many countries are bound by public procurement laws to guard against corruption and misuse of public funds. Such rules can be cumbersome and pose a constraint on the ability of SOEs to operate and invest in a timely manner to meet the competition. Complex, timeconsuming procedures that are not commercially oriented can have a significant negative impact, especially when SOEs are purchasing commodities from world markets where speed and flexibility are paramount. In recognition of these factors, and with increasing competition between SOEs and the private sector, the European Union is drafting new procurement rules for transport, energy, water, and postal sectors where SOEs are prevalent. During the preparation of this toolkit, these rules were not yet finalized. Short of reforming public sector procurement laws more broadly, some countries such as Turkey exempt SOEs from the procurement law for purchases below a certain threshold, although such thresholds are so low that they cover only a fraction of total SOE procurement.

When institutions are weak and monitoring is lax, SOE procurement provides scope for corruption. Thus, a careful assessment of the procurement 
regulations and practices of SOEs should be carried out since any inefficiencies will directly affect their governance arrangements and their ability to procure in an efficient, timely, and transparent manner. The weaknesses can then be addressed either through SOE laws, through separate procurement laws for SOEs, or through improvements in the existing procurement law.

At the same time, states may also favor SOEs in procurement contracts, creating a different kind of market distortion in countries where public procurement accounts for a significant fraction of economic activity. Notwithstanding the care exercised by many public authorities in designing competitive tenders that try to prevent public sector entities from benefiting from advantages in the bidding process, distortions frequently arise in both design and implementation. ${ }^{8}$

Some countries, such as the United Kingdom, have specifically addressed competitive neutrality in procurement contracts through a set of principles of competition put together after consultation with stakeholders (box 2.7). As many possible adverse effects are possible-both advantaging

BOX 2.7

The United Kingdom's Principles of Competitive Neutrality in Procurement Processes for Custodial Services

The Ministry of Justice has separated its regulatory, commissioning, procurement, and bidding functions into different departments to try to avoid any conflicts of interest that arise when assessing public, private, and third-sector bids. The ministry also aims to provide all relevant information in a timely manner to try and reduce any incumbency advantages. The principles focus on five areas:

- Costing. A formula is given that must be applied to all public sector bids to reflect the allocation of indirect costs. Transition, contract administration, and monitoring costs will not be allocated to any bid unless they are additional costs arising out of a particularly novel approach in one bid.

- Grant funding. All bidders must declare any grant funding, including any received by subcontractors. Bidders must attest that no grant will be used to subsidize their bid, including the indirect costs.

- Pensions. Information is given about the Cabinet Office's Statement of Practice on Staff Transfers in the Public Sector. It addresses pensions 
BOX 2.7 continued

and provides guidance on the broader issue of the treatment of staff who are transferred from the public sector. When there is a public sector incumbent, all public sector bids must apply an uplift of 3 percent per year to all payroll costs.

- Risk. A list of risks considered insurable is given, and the principles require that each bid include a limit of liability for each of the listed risks irrespective of bidder type. Any public sector bidder is required to obtain a quotation for commercial insurance coverage. Bidders must identify all other risks contingent on the contract and clearly attribute their true commercial value. These risks include contractor performance, asset and property maintenance risks, and pension costs and liabilities. If a part of the service does not meet the service level stated in the contracts, the contractor incurs a penalty; while a public sector bidder may not ultimately be subject to such financial deductions, its bid shall be evaluated as if these deductions were to apply.

- Tax. Special mention is made of the value-added tax, the corporation tax, and the different liabilities faced by different bidders. The evaluation of bids excludes both types of taxes, although bidders are required to provide details of expected liabilities for both.

Source: BIAC 2011

and disadvantaging SOEs-public authorities should reflect on what competitive neutrality means in relation to procurement. ${ }^{9}$ Recent efforts have been made to analyze the problems resulting from private and public incumbency advantages in procurement and to identify the characteristics that a competitively neutral procurement policy should have. ${ }^{10}$

\section{Listing of SOEs on the Stock Exchange}

Many countries are subjecting large SOEs to capital market discipline by listing shares of corporatized SOEs on the stock markets and applying the more stringent governance requirements under securities laws. Such laws contain stronger requirements for independent directors on the board, treat minority shareholders fairly, and mandate comprehensive and timely financial and nonfinancial reporting. Listing also exposes SOEs to capital market scrutiny, through oversight of expert analysts, rating agencies, and the financial media. 
Major emerging market countries such as Brazil, China, India, Indonesia, Malaysia, and the Russian Federation have listed large SOEs on both domestic and international capital markets. Large SOEs have also been listed on stock exchanges in such diverse countries as Colombia, Kenya, Pakistan, Peru, South Africa, and Vietnam. Indeed, several successful listed SOEs are recognized as world leaders, such as Petrobras, Ecopetrol, Sabesp, and ISAGEN in Latin America.

Listing large SOEs on the stock exchange gives SOEs access to alternative sources of financing and provides greater flexibility for adjusting their capital structure, while contributing to the development of the capital markets. Listing also exposes SOEs to market dynamics and provides a measure of market valuation of net worth. It is also a powerful starting point for strengthening SOE commitment to corporate governance, as the case of Petrobras shows (box 2.8).

Listed SOEs come under the same regulation and scrutiny as other listed companies, including the oversight of the securities regulator, the stock exchange, and, for financial institutions, the central bank or

\section{BOX 2.8 \\ The Listing of Petrobras on the Brazilian Stock Exchange}

Petrobras is one of the world's major oil companies and is currently listed on Brazil's largest stock exchange. In 2010, Petrobras was transformed from a purely state-owned company into a mixed company, through a process of share democratization that represents even today one of the largest capital-increase transactions in the history of capital markets.

The process provided an increase in the market value of the company and an opportunity for the company to access the necessary resources to support its growth strategy. Stock exchange listing also allowed to limit the risks associated with the participation of the state as the sole proprietor through strengthening its corporate governance.

When the state was the sole owner, the company faced the risk of political influence, of vulnerability to hijacking by interest groups, and of an absence of commitment by the board and management. The numerous new shareholders of the company now act as pressure groups that promote and supervise the performance of the company. 
BOX 2.8 continued

By listing its shares, Petrobras accepted the listing rules of the stock market and had to ensure the adoption of international standards of transparency to enhance its credibility in the market and improve its relationship with stakeholders.

Today, Petrobras is a company committed both to aligning the expectations of owners with the economic and political impact of its actions and to adopting international standards through a voluntary regulatory framework. It has become an example of how the process of listing is a starting point for strengthening the company's commitment to corporate governance.

Source: Bernal et al. 2012.

supervisory authority. Exercising regulatory oversight over very large and prominent SOEs can be difficult, however, and requires support and capacity from the relevant parts of the government. Through a stock listing, minority shareholders may also apply pressure and monitor the firm in ways that complement monitoring by lenders.

\section{Developing a State Ownership Framework for SOEs}

In many, if not most, countries, the basic objectives of state ownership are found in SOE laws and regulations that define the legal structure of SOEs; their administration, control, and regulation; and the role of governing bodies such as boards and general assemblies. Together, these laws and documents establish the overall legal and regulatory framework for SOEs.

But the ownership policies of the state-that is, the policy direction for SOEs, the institutional arrangements for exercising the state's ownership rights, and governance practices of SOEs-are often scattered among a variety of documents. In addition to SOE laws and regulations, these may include the founding documents of SOEs or articles of association as well as formal and informal policies and guidelines. This dispersion can lead to unclear objectives; confusion about the roles and responsibilities of SOE shareholders, boards, and management; and inconsistencies in implementation of ownership policies across the SOE sector. It can also make it more difficult to identify policy gaps-gaps that would be more apparent in a single reference document. 
Many countries are establishing new and improved rules to bring greater clarity and consistency to ownership issues. They are doing so through the development of different and sometimes overlapping instruments, including ownership laws and regulations, ownership policies, and codes of corporate governance.

\section{Ownership Laws and Regulations}

A number of countries have revised their existing SOE laws or have developed new, more modern laws and regulations to provide strength and legitimacy to the government shareholder; to codify relations among the shareholder, board, and management; and to outline reporting functions (box 2.9 provides some recent examples).

Demand for better performance in the SOE sector has provided the impetus for adopting more modern legislation. Such laws generally aim

\section{BOX 2.9 \\ Examples of Countries with Modernized State Ownership Laws}

- Finland. In 2007, Finland replaced an older law from 1991 and passed the Act on the Management of State Capital, which was instrumental in separating the state's ownership function from its regulatory functions, clarifying decision-making authorities, and setting legal standards on corporate governance and management of state holdings. In addition, the most important document for the daily operations of the SOEs is the state's ownership policy that was issued in the same year.

- Hungary. In Hungary, the State Asset Law issued in 2007 specifies the rights of the state as owner, the management and use of state assets, and the structure and conditions for the consolidation of organizations managing state assets.

- Philippines. In 2010, the Philippines passed the Government-Owned and Controlled Corporation Governance Act. The act aims to rationalize the structure, existence, and operations of these corporations and is designed to reform the government corporate sector, improve the corporate governance of government-owned and -controlled corporations, and ensure efficient and effective delivery of public services. 
to recast the state's role as owner rather than as policy maker and manager of state assets and are typically based on several key principles: operation of SOEs on a commercial basis; separation of the state's ownership functions from its policy-making and regulatory functions to avoid conflicts of interest, real or perceived; professionalization of corporate governance bodies; and greater transparency and accountability of the SOE sector.

The details of more modern SOE laws differ from one country to the next, but in general they contain several common elements:

- Designation of the state's shareholder representative or ownership entity, including its structure, composition, functions, and accountability framework (covered in chapter 3).

- Broad outlines of a performance-monitoring system to hold SOEs accountable for results (chapter 4).

- Clarification of SOE objectives and, in some cases, the identification and separation of the costs and financing of specific public service obligations or noncommercial goals (chapter 5).

- Establishment of criteria and processes for the appointment of qualified and competent SOE boards, as well as processes for dismissal of board members and for identification of the rights and responsibilities of the board of directors and the management in guiding and managing SOE operations (chapter 6).

- Financial reporting and disclosure requirements for SOEs, which are often in line with private sector practices (chapter 7).

Development of better or new SOE laws and regulations provide the needed weight and legitimacy for improving SOE governance. But passing such laws may not be easy. It requires strong political support and broad consultation with stakeholders to build consensus and buy-in for reforms. A recent example is the 2010 Government-Owned and Controlled Corporation Governance Act in the Philippines. The key features of the act and its development are summarized in box 2.10.

Where the passage of a law is not feasible, new decrees or regulations can be issued to improve SOE governance. Romania and Tunisia provide two examples:

- In 2011, Romania passed an emergency ordinance for improving the process of appointing SOE boards and management. While the new law does not separate ownership from policy making and regulation, it defines in broad terms how ministries should act as owners and focuses on the requirements for the appointment of SOE boards and management. 


\section{The Philippines Government-Owned and Controlled Corporation Governance Act}

The Philippines Government-Owned and Controlled Corporation Governance Act was passed in 2010 to institutionalize reforms in the public corporate sector. The urgency in reforming the sector came about because the total expenditures of government-owned and -controlled corporations (GOCCs) reached the equivalent of 28 percent of the total expenditures of the national government in 2009 and GOCCs accounted for 91 percent of total interagency receivables of the national government. Previous attempts to monitor and coordinate the activities and functions of the GOCCs were carried out through executive issuances that changed along with changes in government. The act aimed to ensure long-term reforms in the public corporate sector.

The act creates a full-time centralized oversight body called the GOCC Commission on Governance (GCG) to formulate, implement, and coordinate GOCC policies. The GCG is headed by a chairman with the rank of cabinet secretary and is authorized to evaluate the performance of GOCCs and ascertain whether they should be reorganized, merged, privatized, or abolished. It is tasked with creating an ownership and operations manual and corporate governance standards for GOCCs that are comparable to those required for banks and for companies listed on the stock exchange and with establishing an objective performance evaluation system and assessing performance periodically.

The act addresses the selection process for GOCC boards of directors, mandating the president to select directors from a shortlist of candidates prepared by the GCG based on fit and proper criteria adopted by the private sector. It empowers the GCG to set compensation, per diems, allowances, and incentives for board members. The law provides a clear definition of the fiduciary duty of board members and executives and requires them to act in the best of interest of the GOCCs. All GOCCs are required to maintain a publicly accessible website with their latest financial statements, corporate operating budgets, and summary of borrowings and other relevant information. 
BOX2.10 continued

The passage of the act took time, but in the end several factors made it possible:

- A favorable environment for its passage was created by publicly exposing the abuses and anomalies of GOCCs and their costs to the economy as a whole.

- Proponents mastered the subject through careful study of all materials and were able to respond to questions during parliamentary debates.

- The bill was included in the president's agenda as a priority reform measure and was certified as an urgent government bill.

- The personal support of key leaders of Congress and the private sector was actively sought.

- Other stakeholders such as labor unions were consulted to discuss concerns about job and compensation issues.

Source: Drilon 2011.

It also covers performance management, transparency and disclosure, and relationships with nonstate shareholders.

- In Tunisia, a new decree for amending the governance of state-owned banks has been recently issued (box 2.11). With this decree, banks can begin to apply new governance practices. The decree should also aid in speeding up the restructuring of state banks.

In addition to reforming general SOE frameworks, countries are also reforming company-specific laws with a view toward modernizing their corporate governance practices. One such example is Chile's state mining company, Codelco (box 2.12).

As discussed below, SOE laws and regulations are sometimes supplemented by ownership policies and SOE corporate governance codes. While they do not carry the same weight and legitimacy as laws and regulations, such policies and codes can be an alternative means for articulating and promoting good corporate governance practices where development of laws and regulations is not feasible.

\section{Ownership Policies}

To bring greater clarity and consistency to ownership issues, some countries have developed comprehensive ownership policies as a tool for communicating expectations and good practices to shareholders, boards, and 
BOX 2.11

\section{Decree for Improving the Governance of State-Owned Banks in Tunisia}

The three state-owned banks in Tunisia suffer from an unfavorable strategic positioning and a weak operating environment. For several years, public banks have been following unsustainable strategic directions. Leveraged to serve economic development policies (agriculture, housing, hotels) and also sometimes used for easy access to finance for cronies of the prerevolutionary regime, the public banks must at the same time meet profitability targets (as listed companies), be financially sound (to guarantee the safety of their depositors), and be in compliance with the prudential norms of the central bank. In addition, as public entities, these banks are subject to Law 89-9 on State Owned Enterprises, which imposes on them significant bureaucratic constraints, notably on procurement and staffing.

The ownership function is absent from the banks, as in other stateowned enterprises in Tunisia. The role of any majority shareholder is to influence the running of a company based on a strategic plan and key performance indicators (financial and, in the case of public companies, social and economic). The legal and regulatory framework for SOEs does not contradict these principles; however, neither of the two criteria mentioned above is applied in practice in Tunisia. The contrat programme, which is the counterpart of the strategic plan in the private sector, is not implemented in public banks, while performance indicators appear very limited. In contrast, the presence of the state is particularly strong in the administrative control of its banks as in the rest of the SOEs.

The degree of professionalism of the banks' boards of directors is insufficient: the boards lack seasoned experts in the relevant areas (banking, finance, audit, accounting, and information technology) and autonomy, given that the vast majority of the decisions taken by the board are valid and enforceable only after approval of the minister of finance.

All these constraints are directly and indirectly responsible for most of the financial difficulties the banks currently face:

- Insufficient capital base. Solvency ratios remain positive to the extent that the central bank has kept lax the prudential rules on classification of nonperforming loans and provisioning ratios. Public banks have 
BOX2.11 continued

greatly benefited from these rules and have avoided the materialization of financial losses.

- Degradation of the loan portfolio quality. Alongside the gradual tightening of prudential norms by the central bank, it is expected that nonperforming loans, which are already nearly twice as high as among private banks (18 percent against 10 percent), will continue to grow rapidly, resulting in new provisioning (and therefore deeper financial difficulties) and a decrease in cash flow (and therefore additional pressure on liquidity).

- Regular loss of their market share vis-à-vis private banks. This share has decreased from 42 percent in 2007 to 36 percent today (despite the increased funding of public enterprises by public banks since the revolution). It is expected that, other things being equal, the loss of market share will continue at a rate of 1-1.5 percent per year.

Improving the governance of SOEs is the urgent initial step in addressing these issues, as a radical change in governance must accompany the recapitalization of the banks. Indeed, in the short term, a new governance framework is necessary for improving management practices and reducing financial losses, as well as for ensuring better implementation of the restructuring plan to be decided by the Ministry of Finance. In the absence of governance reform, the state would likely need to make new and larger recapitalizations in the future.

In view of the urgency, the minister of finance issued a decree in December 2013, which does three things: it excludes banks from most of the administrative burdens imposed by Law 89-9 (for example, human resources policies and procurement rules); it delineates clearly the division of responsibilities among the banks' management, board of directors, and the state as shareholder; and it establishes a transparent and competitive process for the hiring of future board members. This measure is expected to improve banking sector competition and access to finance in the long run. In the medium term, it will stop further deterioration of the banks' financial soundness and facilitate the implementation of restructuring.

Source: World Bank staff. 
BOX 2.12

New Legal Framework for Chile's Codelco

Chile has been making corporate governance improvements in its SOE sector, including in one of its most important companies, Codelco. Founded in 1976 after the merger of major copper mines in Chile and a government takeover of its administration, Codelco has become one of the largest mining companies in the world.

In 2010, the Chilean government enacted Law 20.392, which introduced important changes to Codelco's corporate governance. The new corporate governance law established, among other things, a professional board of directors without the presence of the ministers of mining and finance and representatives from the armed forces. It also established rules on the rights, obligations, responsibilities, and prohibitions as set forth in the corporations law, which governs private companies.

These efforts had several specific aims: to make Codelco more a state company than a government entity; to break the dynamics of political business cycles; to establish a board without public officials; to establish requirements for the selection of board members; to secure a long-term decision-making structure; to establish adequate mechanisms for the capitalization and funding of projects; and to strengthen the financial reporting and transparency of the company.

After implementation of the law, a number of changes to the Codelco board took place. The board went from seven to nine directors. Before the law, the board consisted of the minister of mining (who served as chairman), the minister of finance, two presidential representatives, one armed forces representative, and two union representatives. Today, the board is composed of four directors appointed by the Public Management Council, three presidential representatives, and two union representatives. Board terms have gone from the "presidential term" to four years. Before reform, the board had established general policies, approved investments over US\$50 million, had no liability (civil or criminal), and was not regulated by corporate law; after reform, it adheres to good practices, including designating and appointing the CEO; it has approval authority over the company's strategic plan; it has both civil and criminal liability for its decisions; and it is governed by corporate law.

The new corporate governance law resulted in a new, independent, and technical nominating process for the selection of the CEO; a new 
BOX 2.12 continued

code of corporate governance and a code of ethics; a renewal process for the senior management team; clear definition of the strategy and longterm development plan; corporate restructuring and strengthening of environmental and social responsibility; market alignment of executive salaries; a 10 percent workforce reduction; and a capitalization process of US\$376 million (20 percent of net income). These factors have had a positive impact on Codelco by making it a more competitive and efficient enterprise and have promoted value creation and long-term growth. The improvement in its corporate governance required active state involvement, which allowed for the implementation of a new legal framework aligned with good practices.

Source: Bernal et al. 2012.

management. Less common than corporate governance codes, ownership policies are found in a few countries that have a centralized ownership entity charged with SOE oversight and able to drive the process. Table 2.1 provides some examples of countries that have developed ownership policies. In some countries, such as Finland, ownership policies have been developed to supplement SOE laws.

Ownership policies usually cover several relevant subjects:

- Purpose of state ownership. This section may describe the justification for state ownership and both short-term and longer-term goals. Common justifications include addressing social problems, promoting social goals, correcting market dysfunctions, encouraging development where the private sector is absent, and economic diversification. Justifications express desired outcomes and indicate which enterprises should be state owned.

- Types of enterprises covered by the ownership policy. Enterprises are usually categorized into two broad groups: commercial enterprises providing a product or service, that is, enterprises that could be subject to competition and could operate under private ownership; and enterprises with sectoral policy objectives that operate in a regulated environment (such as water and electricity). These categories are often revisited periodically to determine whether ownership criteria continue to be met and to adjust portfolio practices accordingly.

- Criteria under which SOEs operate. These criteria might address the commercial sustainability of SOEs; the importance of shareholder 
TABLE 2.1 Examples of SOE Ownership Policies

\begin{tabular}{ll}
\hline Country & \multicolumn{1}{c}{ Ownership policy } \\
\hline Bhutan & $\begin{array}{l}\text { His Majesty the King, Royal Charter for Druk Holding and Investments, } \\
\text { 2007, and DHI Ownership Policy, 2010 }\end{array}$ \\
Finland & $\begin{array}{l}\text { Prime Minister's Office, Government Resolution on State Ownership } \\
\text { Policy, 2011 }\end{array}$ \\
Norway & $\begin{array}{l}\text { Ministry of Trade and Industry, The Government's Ownership Policy, } \\
\text { 2008 } \\
\text { Sweden }\end{array}$ \\
& $\begin{array}{l}\text { Ministry of Energy, Enterprise, and Communications, State Ownership } \\
\text { Policy, 2010 }\end{array}$ \\
\hline
\end{tabular}

value, or equity value, relative to social objectives; associated performance measures; and the calculation of (and compensation for) costs of noncommercial objectives. SOEs are usually expected to operate on a commercial basis and to be capable of generating enough cash and profit to replace spent assets and maintain the company's equity value.

- Roles and responsibilities of specific institutions. The respective roles of the state, the ownership entity, the SOE board, SOE management, and independent regulators should all be specified, as well as the separation of financial and policy oversight. Clear definition of roles is a key part of the ownership policy. Management is responsible and accountable for operations. The board is responsible for the strategic direction of the SOE and, ultimately, for performance. The state is responsible for establishing the broad outcomes expected of the SOE and negotiating these with the board. Within government, departments that set policy objectives are usually separated from those that oversee financial performance. Where a centralized ownership entity exists, its role as a source of professional governance practices is described.

- Requirements for transparency and public disclosure. Both the state and SOEs are held accountable for their financial and social performance. Financial reporting requirements are established. Public disclosure covers both financial and nonfinancial information and describes the means of dissemination (including the Internet).

Norway, with a significant SOE sector and commitment to longer-term state ownership, has a detailed ownership policy that aims to insulate SOE operations from unwarranted government interference in operations, while at the same time ensuring that fundamental government objectives are met (box 2.13). Norway's policy focuses, in particular, on the following elements: 
- Role separation. The functions of the state, the board of directors, and management are distinguished.

- Autonomy in operation. Government is removed from operational decision making. SOE (political) direction control can be exercised only through official channels.

- Fiduciary duty. Decisions by boards and management executives must be made consistent with the common legal obligation of board members to exercise a duty of loyalty to the company.

- Role conflict. Important guidance is provided to boards in cases where an SOE's commercial and noncommercial objectives conflict.

BOX 2.13

\section{Summary of Norway's Ownership Policy}

Norway's ownership policy contains the following sections:

- Foreword by the minister. The foreword discusses the role of state ownership, sets out general principles of governance, establishes certain social goals, mentions prior studies, and underscores the importance of transparency and competent boards.

- Scope of the state's direct ownership. The scope of the state's direct ownership includes the list of companies covered by the ownership policy, the state's shareholding in the companies, and the ministry with which companies are affiliated. The ownership policy covers companies for which the state has mainly commercial objectives and important companies with sectoral policy objectives.

- The government's objectives for state ownership. The objectives cite the relevant SOEs, note that the ownership policy is based on a broad political consensus, and identify as key goals the continued presence of important companies in Norway as well as state ownership and control of revenues from natural resources. Other social objectives relate to infrastructure, culture, equality, and health issues.

- Requirements of the companies. The requirements cover the need for a positive return to shareholders, a positive rate of return for commercial SOEs, and efficient operation of social SOEs. They also cover the need for a rational, predictable, and flexible dividend policy; the role of share repurchases; and SOE reporting requirements in line with those for the private sector.

(box continues on next page) 
BOX2.13 continued

- The state's expectations of the companies. This includes the government's expectations of sector-independent considerations that companies must take into account, social responsibility considerations, and the objectives for the ownership of individual companies.

- The government's policy on the remuneration of leading personnel. Remuneration must be competitive but not market leading, with opportunity for capped incentive compensation but no stock options. Responsibility for approval of compensation plans lies with the boards and shareholders.

- The division of roles in the state administration. The roles of the state as policy maker and regulator are separate from its role as owner. The role of central ownership entity as well as line ministries and other government bodies is described.

- The framework for the state's administration of its ownership. The framework describes the legal structure of SOEs as corporations, the applicability of normal company law including stock exchange requirements, and laws relating to state subsidies. The legal framework, executive and ministerial authorities, control of wholly owned as compared to mixed enterprises, voting thresholds, and equal access to information and insider trading are also covered, along with subsidies, freedom of information, principles of good governance and financial management, and the need for transparency of ownership.

- The relationship between the board of directors, the management, and the shareholders. The relationship of the state to the SOE is equivalent to that of an outside shareholder, responsibility for management of the company resides with the board and the executives, and ministerial decision making on operations is prohibited-even for unusual or controversial issues. Board and executive decision making must be based on the SOE's interest, with the board and executive liable for proper management and defense of SOE interests. Boards nominate CEOs. The state exercises its authority through the annual shareholders' meeting and the nomination committee, with nominations based on competence and a prohibition on ministers and civil servants serving as board members. The terms and remuneration for board members are specified. Performance-based pay, which is thought to compromise independence, is ruled out. 
- Noncommercial objectives. Noncommercial goals to be achieved through state ownership are specified in writing-mainly environmental protection, gender equality, and health objectives.

Among developing countries, Bhutan is one of the few with an ownership policy (box 2.14). Its policy defines four objectives of state ownership: (1) to make SOEs more efficient (many are loss making); (2) to address public frustration with the quality of services provided by SOEs; (3) to adapt SOEs to challenges posed by increased global competition; and (4) to clarify social mandates and costs. It also specifies the tasks of Druk Holding and Investments (DHI)-the centralized body responsible for exercising the state's ownership rights-and provides guidance for DHI on how to translate high-level ownership goals into operational practice. DHI is directed to focus on maximizing the return to shareholders (the people of Bhutan), to separate ownership and management, and to promote the growth of the private sector.

Bhutan and Norway both seek to improve the efficiency and effectiveness of their SOEs through better governance, both set out similar principles of separation of policy oversight from shareholder oversight, and both opt for a centralized body to help the government exercise SOE oversight. Yet, these

\section{BOX 2.14}

\section{Summary of Bhutan's Ownership Policy}

Bhutan's state ownership policy is contained in two documents: the 2007 royal charter that establishes the centralized ownership entity Druk Holding and Investments, revised in 2008, and the more detailed ownership policy developed by and for DHI in 2010, updated in 2013. DHI also introduced a corporate governance code in 2013, which provides a set of guidelines for its SOEs based on internationally accepted good practices, as well as guidelines on corporate social responsibility.

The royal charter sets out the overall goals and objectives of state ownership: to accelerate socioeconomic development to achieve the goals of "gross national happiness" (social welfare); to safeguard, manage, and enhance national wealth through prudent investments; to build a strong, dynamic economy as the foundation for a vibrant democracy; 
BOX 2.14 continued

to enhance international economic partnerships; to lead and stimulate private sector development through a culture of innovation, creativity, and enterprise; to prevent corruption; and to promote the economy's competitiveness by making SOEs more efficient and productive.

The charter establishes the objectives and tasks of DHI. Its main purpose is to ensure that SOEs meet the challenges of the corporate sector in a competitive global economy. DHI is to act as the holding company for SOEs transferred under a share transfer agreement entered into between the Ministry of Finance and DHI. It seeks to maximize returns to its shareholders (the people of Bhutan). In addition, its role is to strengthen corporate governance by ensuring clear separation of the ownership and management of SOEs, enhance the performance of SOEs by making them responsible and accountable for their performance, raise funds for investment, and promote the growth of a dynamic private sector.

DHI appoints the boards and directors of companies in its portfolio, tracks company performance, invests in companies, divests shares of SOEs, raises funds, and provides managerial and other support services on a fee basis to both the public and the private sector.

DHI's ownership policy addresses in greater detail the interface among the government, DHI, and the companies; the roles and authority of company boards, chairs, and CEOs; and their appointments and terms of reference. The ownership policy is based on generally accepted principles of corporate governance as outlined in the OECD's Guidelines on Corporate Governance of State-Owned Enterprises.

Source: DHI 2008; 2013.

national policies differ in ways that reflect differences in the local context. Bhutan is undergoing economic and social change to facilitate integration into the global economy, and Norway is a developed economy with an established private sector and a history of SOE governance. Bhutan's use of a royal charter to outline the overall goals of state ownership may reflect the socioeconomic changes envisioned and the attendant need for high-level political direction. Norway's ministerial-level document suggests that its ownership policy, while important, does not imply profound socioeconomic change but is established mainly to provide guidance on the institutional and technical aspects of SOE governance. 
The process of setting formal ownership policies is easier when there is a centralized ownership entity in place that can drive and manage the process of developing the policy. Where ownership responsibilities are fragmented among different line ministries, building support and managing the process can be more difficult and time consuming, especially when parliamentary approval is required. Developing a coherent policy can also be more difficult when there is a large and diverse portfolio of SOEs, with many different legal forms.

\section{Corporate Governance Codes and Guidelines}

As in private sector codes, SOE codes are of three main types: ${ }^{11}$

- Voluntary codes. Some SOE codes are voluntary, encouraging but not forcing SOEs to comply with their provisions. Voluntary SOE codes are found in Bhutan and Egypt, for example.

- Comply-or-explain codes. Some codes are applied on a comply-or-explain basis. In the Seychelles, SOEs are expected to note their compliance with the 2009 Guidelines on the Good Governance of Public Organizations (equivalent to a code) and explain any areas of noncompliance. Another example is the Moroccan code developed in 2011. Like voluntary codes, comply-or-explain codes provide greater flexibility and scope for application of a more customized approach by company.

- Mandatory codes. Given the wide range of SOEs and the need to align commercial, political, and public policy goals, a mandatory or rulesbased code is less common, as it may not allow the flexibility needed by different types of companies. (Listed SOEs, however, are required to follow the listing rules and codes of the stock exchange.) One example is found in Pakistan, which issued the Public Sector Companies Corporate Governance Rules in 2013. The rules apply to all public sector companies that fall under the Companies Ordinance of 1984. In India, the Guidelines on Corporate Governance for Central Public Sector Enterprises were issued in 2007 as voluntary guidelines but based on the experimental phase, and after due interministerial consultations they were made mandatory in 2010. They were also modified based on experience gained and were improved with additional provisions on the formation of remuneration committees and on monitoring compliance (discussed in further detail below).

One school of thought argues that SOEs should always follow private sector corporate governance practices and that no SOE-specific codes with 
potentially weaker practices should be developed. But developing an SOE code can be a way of increasing awareness of governance issues not only within SOEs but also within the government and the ownership entity (where one exists) and among the public. A variety of SOE codes are in effect in a number of countries around the world:

- Many countries-such as Germany,Kenya,Malawi,Mauritius, Mozambique, Poland, and South Africa-have adopted SOE governance codes as a first step toward developing more substantive regulation, especially where the legislative process takes time or the issue of SOE governance is politically contentious.

- Estonia, Latvia, and Lithuania have developed a shared code, the Baltic Guidance on the Governance of Government-Owned Enterprises, which contains general policy recommendations directed at both government and SOEs on how to bring local practices close to the OECD's Guidelines on Corporate Governance of State-Owned Enterprises.

- In Malaysia, the Putrajaya Committee on GLC High Performance, formed in 2005 to oversee the GLC Transformation Program, developed policy guidelines, rather than rules, in a GLC Transformation Manual, to be followed by government-linked corporations. The guidelines clarify the GLC mandate in the context of national development, upgrade the effectiveness of GLC boards, enhance the capabilities of governmentlinked investment companies as professional shareholders, adopt corporate best practices within GLCs, and implement and enforce the GLC Transformation Program.

In some countries, SOE codes have been inspired by private sector governance codes. In South Africa, for example, the Protocol on Corporate Governance in the Public Sector was influenced by the country's well-known King Code. Like in private sector codes, SOE codes typically focus on board composition, the roles and responsibilities of board members, and reporting and audit requirements. In some countries, such as the Baltic countries and Egypt, SOE codes draw from the OECD's Guidelines on Corporate Governance of State-Owned Enterprises, which are directed principally at the state as owner but also include the boards. These codes tend to be broader in scope, covering the regulatory framework for SOEs, the obligations of the state as owner, the equitable treatment of shareholders, the state's relations with stakeholders, transparency, and the responsibilities of the SOE board.

Although a number of different bodies have developed SOE codes, for these codes to have the authority they need, it is usually best that they be developed at the behest of the government departments or ownership 
units responsible for SOEs with the capacity to promote and monitor implementation. In India, Morocco, and South Africa, the government ministries responsible for SOEs developed the codes, while in Germany, the Netherlands, and Poland the equivalent of a ministry of finance created them. In Peru, the SOE code was developed by the state holding company, FONAFE, which acts as the ownership authority for SOEs. In some cases, third parties develop these codes. For example, in Egypt, the Egyptian Institute of Directors developed the SOE Code of Corporate Governance but under the auspices of the Ministry of Investment, which had ownership responsibility for SOEs. In Latin America, CAF-the development bank of Latin America-developed a set of regional corporate governance guidelines for SOEs, based on the OECD guidelines, aimed at encouraging the discussion of corporate governance in the region.

While voluntary codes and guidelines are meant to encourage SOEs to improve their governance practices, ensuring compliance can be a challenge, as companies face few incentives or pressures to comply-especially when codes are developed by third parties. In some cases, SOEs simply lack awareness of the code. Or they may lack the knowledge and practical guidance to implement the code, especially when it contains many aspirations but no clear priorities. In other cases, once the code is in place the ownership entity itself may take only modest steps to disseminate, promote, and monitor compliance with the guidelines, even though promotion of good corporate governance practices should be a key function of such agencies.

Governments can take a number of steps to promote and monitor compliance:

- Disseminating the code to build awareness.

- Developing tools and manuals to help SOEs adopt good governance practices from the code.

- Providing training on the code to companies, owners, and regulators to build understanding of the provisions and how to apply them: in Egypt, for example, the Egyptian Institute of Directors played a vital part not only in preparing and disseminating the SOE code but also in training SOE directors on the code's implementation and developing a manual for implementation.

- Focusing on companies that understand the importance of good governance and use them to demonstrate an active commitment to applying the code, which can be a powerful inducement.

- Developing the capacity of SOE owners and regulators to monitor and evaluate compliance and elevating their role and profile in promoting compliance. 
- Including compliance with the code as a critical part of the performancemonitoring and disclosure systems. In India, for example, the corporate governance guidelines mandate that the annual reports of companies contain a separate section on corporate governance with details of compliance, with a certificate on compliance from auditors or the company secretary. Companies are also required to submit quarterly compliance or grading reports in a prescribed format to their line ministries, which in turn submit a consolidated annual report to the Department of Public Enterprises. Initially, only few companies submitted reports, but the department's reminders and follow-up meetings with line ministries led to higher compliance rates over time (Department of Public Enterprises 2013).

Ownership entities can also use their own codes to encourage change in their portfolio companies. In Peru, for instance, the state holding company FONAFE developed the Framework Code of Good Corporate Governance of SOEs and then required individual SOEs to draw up their own governance code based on that framework. Once SOEs had developed their code, they were asked to evaluate their performance against it.

More and more, countries require SOEs to report on how they comply with the provisions of their code; if not, to explain why they are not complying; and to highlight steps they are taking to improve compliance. In Pakistan, for example, the Securities and Exchange Commission has developed a template for monitoring compliance with its corporate governance rules. The compliance statement is required annually. It requires companies to indicate for each rule and subrule the extent to which they are fully compliant, partially compliant, or noncompliant, with explanations provided. The statements must be approved by an independent external auditor and be integrated into the SOE performance-monitoring framework. Companies will also be required to report on compliance with the rules in their annual reports. By evaluating SOE compliance regularly, the Securities and Exchange Commission-and ownership units in general-will also be better prepared to revise and update the code as needed.

Corporate governance scorecards are also growing in use. Scorecards use international standards as a benchmarking tool to assess corporate governance practices in a given country. While scorecards are commonly used in the private sector, they are catching on in SOEs as well. The Philippines, for example, developed a scorecard in 2009, and its experience shows how benchmarking by an independent external body-in this case the Philippines Institute of Corporate Directors-in collaboration with the government can professionalize the process and give it greater credibility (box 2.15). 
BOX 2.15

\section{Corporate Governance Scorecard in the Philippines}

In 2009, the Department of Finance of the Philippines, in partnership with the Philippines Institute of Corporate Directors (ICD), undertook the development of a corporate governance scorecard to benchmark the governance of 30 or so government-owned and -controlled corporations, virtually all of which were wholly owned by the national government. The initiative used the OECD's 2005 Guidelines on Corporate Governance of State-Owned Enterprises as a benchmark and drew from the ICD's experience with scorecards for all public companies in the Philippines. The goal was to raise awareness on corporate governance issues among GOCCs and to identify areas for improvement.

The ICD worked closely with the Office of the President, the Department of Finance, and key stakeholders to develop the scorecard and gather data. A survey was carried out to complement information gathering from available documents. Benchmarking initially fell under two categories: board responsibilities and disclosure and transparency. A questionnaire was developed based on these categories. The benchmarking relied on self-rating by GOCCs, which compared their practices with the questionnaire. Volunteers were then asked to validate the self-ratings, using documents submitted by the GOCCs to substantiate them. The results were then tabulated and analyzed.

GOCCs scored significantly lower than their private sector counterparts in the two areas rated. The gaps in good practice revealed by the benchmarking exercise helped identify many opportunities for improvement in the boards. The benchmarking was widely considered a useful tool for encouraging GOCCs to evaluate and improve their governance practices.

The scorecard was subsequently expanded to include all six OECD guidelines: the legal and regulatory framework, the state as owner, equitable treatment of shareholders, relations with stakeholders, disclosure and transparency, and boards of directors. Corresponding weights were 10 percent for the first four guidelines and 30 percent for the last two guidelines. The goal is to help raise the standard of GOCC corporate governance practices in the Philippines.

Source: Moreno 2006; OECD 2010. 
The approaches used in Peru and the Philippines rely on SOEs to engage voluntarily in self-evaluation against the code (in the case of Peru) or against international standards (as in the case of the Philippines). In both countries, the codes and standards have served as tools of persuasion, and through monitoring instruments the government was able to engage the SOEs.

Given the voluntary nature of codes and guidelines, noncompliance carries few if any consequences. But this does not mean that voluntary codes should simply be made mandatory. Although some core parts of a voluntary code may find their way into compulsory formal rules and regulations, the objective of governance codes is not just to ensure compliance but also to motivate change in the governance culture and encourage SOEs to embrace the true spirit of corporate governance and not to view it as a mere boxticking exercise.

Countries considering the development of an SOE code might follow the steps outlined in box 2.16 .

Finally, measuring the impact of the code on SOE corporate governance practices through surveys, corporate governance assessments, and scorecards is important. But broader impacts can also be considered through measures such as the number of references to the code in the media, number of official endorsements of the code, and impact on broader corporate governance frameworks such as the passage of new laws and regulations.

BOX 2.16

\section{Steps in Developing an SOE Governance Code}

SOE governance codes come in different forms. Who develops them, how they are developed, and what their purpose is differ from country to country. But any country seeking to develop an SOE code might consider these basic steps:

- Reach agreement within the government on the need for and purpose of the code and the desired outcomes. High-level support for developing and implementing a code is useful.

- Take time early on to consider the purpose of the code and develop an implementation plan. For example:

- Consider whether the code should be used as a benchmarking tool, as a model for individual SOE codes, or as a formal requirement. 
BOX 2.16 continued

- Identify an appropriate backer or champion for preparation of the code.

- Nominate a leader or champion to be the public face of the code.

- Garner commitment from leaders (administration officials, board members, SOE executives).

- Design complementary training and awareness-raising activities.

- Identify key contributors to the code:

- Line ministry and finance ministry officials.

- Ownership entity where one exists.

- SOE executives and board members.

- Academics.

- Private sector board members, executives, and other experts.

- High-level political supporters.

- Form a working group and define its terms of reference.

- Analyze and discuss existing codes.

- Develop a first draft.

- Disseminate the draft among relevant stakeholders, including the general public, for comment.

- Collect and publish the comments.

- Formally adopt the code.

- Roll out the code according to the implementation plan.

- Periodically examine the impact of the code and adjust it and its implementation as needed.

\section{Notes}

1. The term SOE here is used interchangeably with other terms that are commonly used in different countries, such as public enterprises, government-owned corporations, government business enterprises, public sector undertakings, and parastatals.

2. For instance, public entities that perform essential state functions-such as environmental protection or aviation administration-may generate significant revenues from compulsory licenses or user fees. And they may have a formal legal status similar to SOEs. Yet, these entities are not generally categorized as SOEs.

3. Company legislation may also apply to SOEs in other legal forms, such as foundations, limited or general partnerships, and limited partnerships with shares. 
4. Several OECD countries as well as the European Union have established specific competitive neutrality frameworks. These frameworks go beyond addressing the anticompetitive behavior of SOEs to also establish mechanisms to identify and eliminate any competitive advantages that may exist, including with respect to taxation, financing costs, and regulatory neutrality. The experience so far with such formal arrangements shows that jurisdictions that have them have generally been successful in rolling back state subsidies and, on the evidence to date, have obtained significant economic efficiency gains.

5. Details on the Australian policy can be found in the "Australian Government Competitive Neutrality Guidelines for Managers," August 2004. See http://www.finance.gov.au/publications/finance-circulars/2004/01.html.

6. See http://www.worldbank.org/ifa/IPG\%20-\%20Revised\%20Pples\%20FINAL \%20\%5B21\%20Dec\%202005\%5D.pdf.

7. The toolkit (World Bank 2004) provides detailed information on each aspect of a labor-restructuring program, from program design to execution and monitoring and evaluation, as well as on the importance of engaging with stakeholders throughout the process.

8. In other cases distortions arise from a true lack of commitment to a fair procurement policy by different levels of government (central, regional, local).

9. For example, sometimes direct purchase is used to facilitate contracting instead of public procurement. This happens when public authorities request delivery of products or services directly from the organizations they own instead of putting them out to tender.

10. Examples are provided by Julius (2008); Sturgess (2006); and Comisión Nacional de la Competencia (2010).

11. Use of the word code varies and sometimes leads to confusion. Code is often understood to mean a statute, particularly in civil law countries. In the usage employed in the toolkit, however, code means a voluntary document that provides guidance on best practices and is often "enforced" through disclosure requirements.

\section{References}

Aivazian, Varouj, Ying Ge, and Jiaping Qiu. 2005. "Can Corporatization Improve the Performance of State-Owned Enterprises Even without Privatization?” Journal of Corporate Finance 11: 791-808.

Albert, S., and C. Buisson. 2002. "Entreprises Publiques, Le Role de l'Etat Actionnaire." La Documentation Francaise. Paris.

Bernal, Andres, Andres Oneto, Michael Penfold, Lisa Schneider, and John Wilcox. 2012. "Corporate Governance in Latin America: Importance for State-Owned Enterprises." Public Policy and Productive Transformation Series 6/2012, Corporacion Andina de Fomento, Caracas.

Berne, Michel, and Gerard Pogorel. 2004. "Privatization Experiences in France." CESifo Working Paper 1195, Center for Economic Studies, Munich. http://ssrn .com/abstract $=553962$. 
BIAC (Business and Industry Advisory Committee). 2011. "Competitive Neutrality in the Presence of State-Owned Enterprises," Paris. http://www.biac.org /statements/investment/corpgov/10-11-15-FIN-BIAC-paper-on-Competitive -Neutrality-in-the-Presence-of-SOE.pdf.

Bozec, Richard, and Gaetan Breton. 2003. "The Impact of the Corporatizaton Process on the Financial Performance of Canadian State-Owned Enterprises." International Journal of Public Sector Management 16 (1): 27-47.

Capobianco, Antonio, and Hans Christiansen. 2011. "Competitive Neutrality and State-Owned Enterprises: Challenges and Policy Options.” OECD Corporate Governance Working Paper 1, Organisation for Economic Co-operation and Development, Paris.

Comisión Nacional de la Competencia. 2010. Guide on Public Procurement and Competition. Madrid: Comisión Nacional de la Competencia.

Cordeiro, J. L. 2007. El Desafio Latinoamericano... y sus Cinco Grandes Retos, Segunda Edición. Bogotá, Colombia: McGraw-Hill Interamericana.

DPE (Department of Public Enterprises). 2013. Annual Report on Public Enterprises, 2012-2013. New Delhi: DPE.

DHI (Druk Holding and Investments). 2013. Ownership Policy, 2nd ed. http://www.dhi.bt/forms/2013/Ownership\%20Policy\%202013.pdf.

—. 2008. Royal Charter for Druk Holding and Investments. Rev. version. Thimphu, Bhutan. http://www.dhi.bt/forms/Royal\%20Charter\%20011108.pdf.

Drilon, Franklin M. 2011. "Recent Endeavors of the Philippines on Drafting a New SOE Act." A Presentation for the 6th OECD Meeting of the Asia Network on Corporate Governance of State-Owned Enterprises, Seoul, Korea, May.

Gowlland-Gualtieri, Alix. 2007. "South Africa's Water Law and Policy Framework." Working Paper 2007-03, International Environmental Law Research Center, Geneva.

Julius, DeAnne. 2008. "Understanding the Public Services Industry: How Big, How Good, Where Next?” Public Services Industry Review. http://www.bis.gov .uk/files/file46965.pdf.

Ministry of Trade and Industry. 2008. The Government's Ownership Policy. Oslo: Ministry of Trade and Industry.

Moreno, Jonathan Juan D.C. 2006. "The Corporate Governance Scorecard for GOCCS/GFIs." Presentation at the "Asian Roundtable on Corporate Governance," Singapore, May 15-16.

Organisation for Economic Co-operation and Development. 2005. OECD Guidelines on Corporate Governance of State-Owned Enterprises. Paris: OECD.

-2010. Policy Brief on Corporate Governance of State-Owned Enterprises in Asia: Recommendations for Reform. Paris: OECD.

Sturgess, G. 2006. A Fair Field and No Favours: Competitive Neutrality in UK Public Services Markets. London: Serco Institute.

World Bank. 2004. Labor Issues in Infrastructure Reform Toolkit. Washington, DC: World Bank. 



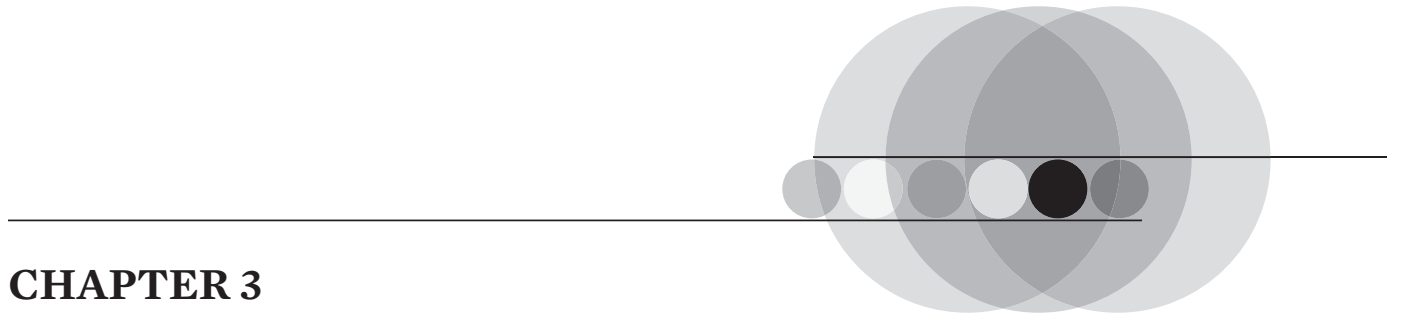

\section{State Ownership Arrangements}

Ownership reforms of state-owned enterprises (SOEs) seek to clarify the state's role as owner, reduce fragmentation of ownership responsibilities across multiple institutions, and enhance accountability for results. Such reforms should also aim to give SOE boards and management greater autonomy in operational decision making. A critical goal is to separate the state's ownership functions from its policy-making and regulatory functions to sharpen the focus on ownership issues and minimize the conflicts of interest that may arise when the roles are combined, especially in sectors and activities where the private sector is present. These reforms involve moving away from traditional ownership models in which line ministries have ownership responsibilities to centralized ownership arrangements.

This chapter provides a brief overview of ownership arrangements and focuses on the steps involved in creating effective ownership arrangements. It covers the following:

- Overview of ownership arrangements

- Improving traditional ownership arrangements

- Creating advisory or coordinating bodies to facilitate the state's ownership role

- Centralizing the state's ownership functions

- Ensuring the effectiveness of ownership arrangements 


\section{Key Concepts and Definitions}

The term ownership arrangement refers to the way in which the state organizes itself to exercise its ownership rights over SOEs. In some cases, the body or entity that exercises the ownership rights is the legal owner of the assets. In other cases, the entity that legally owns the assets may have delegated the ownership rights to another entity, such as a ministry or a specialized ownership body. For example, a finance ministry may legally own SOE shares while delegating to line ministries the rights typically associated with the ownership of a corporation, such as nominating board members or making major decisions. Thus, the term ownership arrangement, as used here, refers not just to the legally recognized owner of the assets but also to the body or entity that has the authority to exercise the state's ownership rights.

The term ownership function refers to the fundamental rights and normal functions exercised by shareholders when they own shares in a company or when they own a company outright. It includes, for instance, the right to nominate (or appoint) members to the board and the right to vote shares at the general meeting of shareholders. Normal shareholder functions also include monitoring the performance of the company and approving or investing additional capital when necessary.

\section{Overview of Ownership Arrangements}

Ownership arrangements have evolved over time as SOEs have changed in form and as governments have sought to improve their productive capacity. While countries vary substantially, ownership models fall broadly into four categories:

- The decentralized model, where ownership responsibilities are dispersed among different line ministries.

- The dual model, a variation of the decentralized model, where in addition to line ministries a second ministry, such as the ministry of finance, may also have certain responsibilities.

- The advisory model, where ownership remains dispersed but an advisory or coordinating body is created to advise ministries on ownership matters.

- The centralized model, where ownership responsibilities are centralized in an entity or entities that may be independent or may fall within government. 
While useful for comparison and classification, the models are not rigid archetypes. Specific country arrangements often combine elements of more than one model: for example, the split-authority characteristic of the dual model may be comingled with an advisory board. In addition, governments may assign their SOEs to separate clusters (for example, commercial versus noncommercial enterprises) and apply a different ownership model to each group. Each of the four models also has particular strengths and weaknesses, as discussed in the sections that follow.

The decentralized and dual models are the more traditional ones for organizing the state's ownership arrangements. Countries are moving away from these models, however, toward the advisory and centralized models to bring focus and professionalism to the state's ownership role. When adopting models with greater independence is not practical in the short term, reforms to improve on traditional arrangements can be instituted.

\section{Improving Traditional Ownership Arrangements}

\section{Key Features of the Decentralized Model}

The decentralized ownership model carries over from the past, when commercial activities were often organized as government departments within line ministries. Ministries were responsible both for providing the product or service and for making sectoral policy. Such arrangements were inefficient because activities were not subject to competition and because ministries and bureaucrats exercised direct control over strategic and operational decision making, often giving priority to the state's policy goals at the cost of efficiency. And the arrangement posed an inherent conflict because the state was both the provider of a service or product and the regulator or monitor of its own performance. In addition, the decentralized model tends to link SOEs with public policy, increasing the chances that enterprise assets will be misused for narrowly political purposes.

To address these inefficiencies, governments created separate legal identities for commercial activities through corporatization, a process still under way in many countries. The legal transformation of state assets or agencies into state-owned corporations was intended to bring SOEs under commercial laws and keep the state at arm's length, while introducing corporate management practices through new governance bodies, most typically a board of directors and a general assembly. Corporatization was also intended to shift the functions of line ministries from providing a service or product 
directly to overseeing SOEs, while SOE boards and management became responsible for setting strategy and implementing operational plans.

The decentralized model still exists in a number of countries. But in many others it has evolved to dual, advisory, or centralized models as its shortcomings have become increasingly recognized:

- Scope for political interference. While corporatization was intended to create distinct roles for ministries and SOEs, the distinctions proved hard to achieve in practice. Ministries, for example, are tempted to restrict or bypass the board and control day-to-day operations, particularly when chief executive officers (CEOs) are appointed directly by the government, as is common in many emerging market countries. In some cases, the state views SOE boards as a bureaucratic hindrance and may bypass them. Alternatively, the board may exercise a "rubber stamp" function and become a simple conduit for ministerial instructions. Either way, the board fails to perform its proper role in good corporate governance.

- Conflicts between ownership and policy-making functions. Many countries have created independent regulators for regulated industries. But line ministries are still responsible for both ownership and policy-making functions. These dual responsibilities not only dilute the ownership function but also create potential conflicts of interest in competitive sectors. For example, conflicts occur when the state sets as a policy goal the provision of a necessary product or service at a price below the cost of production or when ministries are large purchasers of the SOE's products and services. Having line ministries serve as owners in a competitive environment and be responsible for policy making for the sector as a whole can create disadvantages for private sector companies or lead to allegations of bias in pricing and procurement decisions.

- Fragmentation of ownership responsibilities and diffused accountability. Fragmentation of ownership responsibilities among a number of line ministries (and other agencies) undermines ownership focus, consistency in approach, and accountability. It is also not conducive to the sharing of lessons learned, such as, for example, how to structure performance contracts. These problems can be more acute in countries with a large number of ministries and agencies in charge, although fragmentation even among a small number of ministries may lead to similar problems.

- Insufficient ownership capacity. Ministries tend to focus on the SOE's achievement of operational targets rather than on its financial performance. Moreover, ministries often lack staff with the commercial and financial experience to properly exercise the state's ownership functions. Indeed, the skills and experience necessary for operating a ministry are 
likely to differ significantly from those necessary for operating or monitoring commercial SOEs. The involvement of multiple entities also leads to the dispersion of scarce ownership skills and capacity where they do exist.

- Lack of adequate oversight of the SOE sector as a whole. As responsibilities are spread among many different agencies, no one entity is actively overseeing and monitoring SOEs as a whole.

\section{Key Features of the Dual Model}

To introduce checks and balances and promote both technical and financial oversight, some countries have adopted a dual ownership model in which the ministry of finance has responsibilities in addition to those of the line ministries. These typically include approving annual SOE budgets, subsidies, or major financial transactions and monitoring the financial performance of SOEs. In the Czech Republic and Mexico, for example, line ministries vote the state's shares, while the Ministry of Finance oversees the financial and operational performance of the SOEs. In Zambia, ownership functions are shared between the Ministry of Finance and National Planning and a line ministry. And in Morocco, the Department of Public Enterprises in the Ministry of Economy and Finance oversees the budget and performance of SOEs.

The potential advantage of the dual ministry model over the decentralized model is that it provides for overall financial oversight of individual SOEs and the SOE sector as a whole. Thus, in the best case, the dual model adequately balances the interests and objectives of the line departmentensuring that the policy and service delivery roles of the SOE are being met-against the financial performance objectives of the government. But the model also has its weaknesses. Finance ministries typically focus on budgetary and financial issues but may lack the authority and power that line ministries have over SOEs, as well as the capacity to act as an owner and strong advocate for SOE reforms. Moreover, the dual model, like the decentralized model, allows for the continued dispersion of other key ownership functions, such as board nominations, planning and investment decisions, and monitoring of performance. This depiction of a role for just two government ministries or departments is a simplification of an often more complex reality when other groups were involved. Cabinets may approve board appointments and decisions related to major investments and borrowings. Personnel boards may have a say in employee decisions. State audit institutions may perform inspection functions. And planning ministries may shape planning and investment matters. 


\section{Steps to Improve Traditional Models}

Because decentralized and dual models typically result in a lack of focus on ownership issues and a lack of SOE accountability, countries are adopting a more centralized approach through the creation of advisory bodies and ownership entities (as discussed in subsequent sections). For countries where centralization is not feasible in the short term, measures can be taken to improve existing ownership arrangements and put them on a path toward greater effectiveness and gradual centralization. Improving existing ownership arrangements involves several practical steps:

- Limiting line ministries to performing core ownership functions. These include voting at annual general meetings, overseeing board appointments, and monitoring SOE performance. In all other matters, ministries should limit informal intervention in SOEs' day-to-day affairs and exercise their ownership rights through the government nominees on the board.

- Developing concrete safeguards against political interference in commercial decision making. As part of good governance practice, Canada's Business Development Corporation, for example, reports any undue pressure from politicians on its board of directors regarding credit decisions, which has dramatically deterred political interference in such decisions (Rudolph 2009). In Estonia, ministers' rights to issue instructions to SOE directors have been abolished; the main channel of influence is now the annual shareholders' meeting. In Israel, complaint mechanisms are in place to prevent ministerial interference, although there have been some reports of interference in staffing decisions (OECD 2011). Such limits are essential to bringing greater clarity to the state's ownership role, to reducing the scope for discretionary influence, and to increasing SOE autonomy in decision making.

- Providing SOEs more autonomy from line ministries and empowering SOE boards to take on greater responsibilities. To achieve these goals, the appointment process for SOE boards and management must be professional and transparent, with an emphasis on technical, financial, and corporate governance skills. Clear delineation of the roles and responsibilities of the different parties must also be established.

- Strengthening existing monitoring units in ministries of finance. The units can develop a better understanding of the SOE sector and gain experience and credibility in overseeing it.

- Developing or strengthening SOE corporate governance tools and guidelines. Such tools help formalize governance structures and help ministries and companies begin to establish clear boundaries and relationships. 
- Encouraging greater public oversight through public disclosure of information. Disclosure of information also helps to create pressure for change.

- Developing a system to monitor and benchmark the performance of ministries as owners. A number of countries are developing performance management frameworks for government ministries and departments to monitor and hold them accountable for results.

- Creating an advisory or coordinating body or, when such a body already exists, enhancing its role and capacity to increase its effectiveness. To be effective, the body must possess the necessary skills, resources, and political backing to deal with the ministries, companies, and various other institutions involved.

\section{Creating Advisory or Coordinating Bodies}

The advisory model involves creating advisory or coordinating bodies to help professionalize the state's ownership role, promote good governance practices in individual enterprises, and bring consistency to SOEs as a whole. These bodies also aim to support learning and sharing of experience among SOEs and, in some cases, to begin the transition from a decentralized to a fully centralized model.

\section{Key Features of Advisory or Coordinating Bodies}

Various countries have created advisory or coordinating bodies, usually located in a central ministry such as finance or economy (table 3.1). In a few cases they may be located in a line ministry with the most number of SOEs, as in India.

Such bodies may cover all or some SOEs. For example, in New Zealand the Commercial Operations group in the Treasury is the advisory body for

TABLE 3.1 Examples of SOE Advisory and Coordinating Bodies

\begin{tabular}{lll}
\hline Country & \multicolumn{1}{c}{ Name of entity } & \multicolumn{1}{c}{ Location of entity } \\
\hline India & Department of Public Enterprises & Ministry of Heavy Industries \\
New Zealand & Commercial Operations & Treasury \\
Seychelles & $\begin{array}{l}\text { Public Enterprise Monitoring } \\
\text { Department }\end{array}$ & Ministry of Finance \\
Thailand & $\begin{array}{l}\text { State Enterprise Policy Office } \\
\text { (for nonfinancial SOEs) }\end{array}$ & Ministry of Finance \\
& Fiscal Policy Office (for financial & \\
& SOEs) & \\
\hline
\end{tabular}

Source: Official websites and annual reports. 
all 60 financial and nonfinancial SOEs. In India, by contrast, the Department of Public Enterprises covers only nonfinancial SOEs in the state portfolio. Similarly, in Thailand, the State Enterprise Policy Office in the Ministry of Finance is responsible for exercising the state's ownership rights for all nonfinancial SOEs (majority and minority owned), while the Fiscal Policy Office in the ministry covers financial SOEs.

Although the specific functions of advisory and coordinating bodies may vary from one country to another, they generally provide governance and performance advice to ministries and the government. These entities typically carry out the following functions:

- Developing policies, tools, and guidelines for governance.

- Advising or assisting the board nomination process, including proposing candidates for board positions.

- Monitoring the performance of SOEs through performance contracts or statements of corporate intent (see chapter 4).

- Preparing aggregate information on SOEs and disseminating it to the parliament and the public.

While most such bodies have mainly an advisory or coordinating role as described above, the United Kingdom's Shareholder Executive is an example of a hybrid, with both advisory and executive roles. In its advisory role, it counsels shareholder departments of ministries, supports the board appointment process, monitors SOE performance, and conducts aggregate reporting for the 27 enterprises in its portfolio. In addition, it has executive authority over a few SOEs based on performance contracts with ministries. In its executive role, it is accountable to both the ministers and the shareholding departments, while in its advisory role it is accountable to the shareholding departments.

The advisory model provides an option for strengthening the state's ownership arrangements, especially in countries with a strong public sector administrative culture and a large and diverse SOE portfolio that may make full centralization difficult. It can also be an option in countries with weak capacity and weak governance environments and where an incremental process of learning by doing may be the most feasible and appropriate approach. In such circumstances, creating an advisory or coordinating body may also avoid the concentration of power in a single entity.

At the same time, the advisory model only partially addresses the drawbacks of the decentralized or dual models:

- Line ministries remain both owners and policy makers and sometime regulators, allowing continued scope for conflicts of interest. 
- Continued dispersion of SOEs among many ministries may allow an expanded scope for day-to-day political interference.

- Without sufficient authority or powers, advisory or coordinating bodies may be ignored by ministries and SOEs.

- In the absence of skills, resources, and political backing, advisory bodies themselves may lack both the capacity to deal with ministries, companies, and other institutions and the ability to influence and drive change.

Even successful advisory bodies can face such problems, as examples from India and the United Kingdom show (box 3.1).

BOX 3.1

\section{Challenges and Constraints of Advisory Bodies in India and the United Kingdom}

India's Department of Public Enterprises has many of the classic functions of an advisory or coordinating body. It helps prepare governance guidelines, supports the development of objectives for SOEs, and is a source of information for Parliament and the public. As is common under the dual approach, other government agencies continue to play a substantial role in the governance of SOEs. Line ministries still exercise the ownership rights, with the result that the department's influence remains relatively modest. Strong line ministries create the potential for conflicts of interest between the shareholder and the policy functions. In addition, as many as 38 ministries exercise close control of SOE operations. With such a large number of stakeholders, imposing a consistent shareholder perspective and applying a consistent governance strategy are difficult.

In the United Kingdom, a 2007 study shows that the Shareholder Executive faces similar problems. Because it lacks a mandatory role as the government's shareholder, it has relatively little power and depends largely on the voluntary cooperation of line ministries. As a result, its advice and expertise are not harnessed as effectively as they could be; its ability to provide finance is limited, which constrains its effectiveness; and its need to operate within civil service pay and grading limits may make recruiting skilled staff difficult. Moreover, the Shareholder Executive continues to grapple with the fundamental challenge of reconciling the objectives of public policy and shareholder value-a difficult challenge, as the cost of meeting public policy objectives can adversely affect shareholder value.

Source: World Bank 2010; National Audit Office 2007. 


\section{Steps to Strengthen Advisory or Coordinating Bodies}

Some countries have addressed the problems of advisory bodies by creating fully centralized entities to carry out the state's ownership functions. But when centralization is not an immediate option, specific steps can be taken to strengthen the role and capacity of the advisory bodies:

- Making greater use of technical and financial experts and advisers, particularly in specialized areas such as performance monitoring, internal controls, and risk management.

- Increasing exposure to international trends and forums for the regular exchange of experience.

- Providing training and study tours for staff to expose them to good practices and lessons.

- Monitoring compliance with laws, regulations, or corporate governance guidelines, while creating incentives for ministries to work closely with the advisory body to promote corporate governance improvements.

\section{Centralizing the State's Ownership Functions}

In recent years, the models discussed above have been supplanted by more centralized approaches that concentrate SOE ownership authority in a single specialized entity. Under a centralized ownership model, the specialized entity serves as the shareholder representative with oversight responsibility for SOEs. It owns the SOE shares or is responsible for exercising all ownership functions on behalf of the state as owner, while the line ministry is responsible for policy making and the regulatory environment in which SOEs operate.

\section{Objectives of Centralization}

The main objectives of centralized ownership arrangements are increasingly viewed as good practice:

- To separate the state's ownership functions from its policy-making and regulatory or supervisory functions to help avoid or minimize potential conflicts of interest (box 3.2).

- To minimize the scope for political interference and bring greater professionalism to the state's ownership role by pooling specialized capabilities and scarce resources.

- To promote greater coherence and consistency in applying corporate governance standards and in exercising the state's ownership role across all SOEs. 
BOX 3.2

\section{Separation of Ownership and Regulation}

The state often plays a dual role as market regulator and owner of SOEs where ownership and regulatory functions may be combined within one body, such as in a line ministry or a central bank. Good practice calls for clear separation of these responsibilities within government to prevent conflicts of interest, avoid undermining both functions, and ensure a level playing field. SOEs should be supervised and regulated as if they were privately owned.

In the case of state banks, the regulatory framework should provide a level playing field between state banks and private banks. There should be limits on the activities of the institutions, rules governing minimum capital, supervision of the institutions' internal controls and other means for limiting risks and expenses, and annual reports by supervisors. Treating state banks as banks avoids a number of problems, including predatory pricing and crowding out of the commercial banks; such treatment promotes a fair relationship between the development banks and the commercial banks. The influence of the supervisory agency will depend on the degree of independence of the supervisor as well as the independence of the board chair. A development bank subject to bank regulation is more likely to develop proper systems of risk management that may result in increasing its efficiency.

Nonfinancial SOEs operating in deregulated markets should also be regulated as other market participants. In tandem with the creation of ownership agencies, many countries have created independent sector regulators, which is a step in the right direction, although their independence and power in relation to line ministries may be questionable. In others, however, the ownership function and regulation are still not effectively separated. In some of these cases, SOEs themselves continue to have regulatory powers, while ministries are still regulators in others. The goal should be to maintain effective separation as it is fundamental for ensuring a level playing field with the private sector and for avoiding competitive distortions. Clear laws and regulations should be developed to protect the independence of the regulators, especially in relation to line ministries. Appropriate financial and human resources should also be provided to allow regulators to function adequately with the right degree of operational independence.

Source: Scott 2007; Rudolph 2009; OECD 2010. 
- To manage state assets in a way that protects shareholder value. ${ }^{1}$

- To achieve greater transparency and accountability in SOE operations through better oversight and performance monitoring.

Centralized ownership arrangements bring greater independence, focus, and professionalism to the state's ownership role, provided certain key factors are in place to ensure their effectiveness (as discussed in greater detail below). The centralized model differs from the advisory model in several important ways:

- It identifies the state's ownership functions, makes them more distinct and transparent, and separates them from its policy-making, regulatory, and supervisory functions.

- It delegates ownership functions to a designated entity that takes a shareholder and governance perspective and plays a more direct role in exercising the state's ownership rights.

- It delegates strategy and day-to-day decision making to SOE boards and management while policy-making and regulatory functions are left to line ministries and to regulators and supervisors.

\section{Coverage of Centralized Arrangements}

Centralized ownership arrangements may cover some of a country's SOEs or all of them. They usually cover enterprises that are wholly or majority owned by the state; some may also include minority holdings (although minority shares are more often held by privatization agencies following the completion of privatization transactions). Some entities cover both commercial and noncommercial SOEs; others cover only commercial SOEs, while line ministries remain responsible for utilities and noncommercial SOEs. Coverage may also depend on the legal status of a company, as the examples below illustrate:

- In Azerbaijan, the State Committee for Management of State Property acts as the ownership entity of small and medium SOEs that are jointstock companies, while ownership responsibilities for larger SOEs are divided among ministries, the cabinet, the Office of the President, and the State Committee on Management of State Property.

- In Finland the Ownership Steering Department is the ownership body for the 28 SOEs that are under the Office of the Prime Minister, including Finnerva, the state-owned development bank, while 21 other specialassignment companies are handled by other ministries. 
- In Mozambique, the ownership entity, the Institute for the Management of State Holdings, holds the majority of commercial SOEs, while state utilities operate under the supervision of the Ministry of Finance.

- In South Africa, the Department of Public Enterprises in the Treasury covers nine of the largest SOEs in nonfinancial sectors, while remaining nonfinancial SOEs fall under line ministries. The Treasury is the shareholder representative for financial SOEs.

- In Turkey, the Treasury is the ownership entity for all SOEs wholly owned by the state, including utilities and financial SOEs (in close consultation with line ministries), while the Privatization Administration is the ownership entity for majority-owned SOEs designated for privatization.

- In Ukraine, the State Property Fund is responsible for SOEs that are jointstock companies, while line ministries are responsible for noncorporatized SOEs.

\section{Types of Centralized Arrangements and Key Functions}

Two broad types of centralized entities are widely used: (1) government ownership agencies that are under the direct authority of the government; and (2) company-type structures, such as holding companies or investment companies, that have separate legal identities and greater independence from the government (table 3.2).

Government Ownership Agencies. Different approaches have been used to create ownership agencies under the authority of the government.

Stand-alone ministry. One approach, and a relatively rare one, is to create a stand-alone ministry with responsibility for SOE ownership functions. Indonesia's Ministry of State-Owned Enterprises is an example (box 3.3). The goal in creating the ministry was to bring consistency and oversight to the sector as a whole, while the Ministry of Finance carried out financial monitoring. While joint oversight of the Ministry of State-Owned Enterprises and the Ministry of Finance initially created problems of accountability and was difficult to manage, over time as roles and responsibilities became clear, centralization helped achieve better oversight of the sector as a whole.

Ownership department or unit. A second and more common approachoften easier than creating a new ministry-is to create an ownership department or unit within a central ministry, commonly the ministry 
TABLE 3.2 Types of Centralized Ownership Arrangements

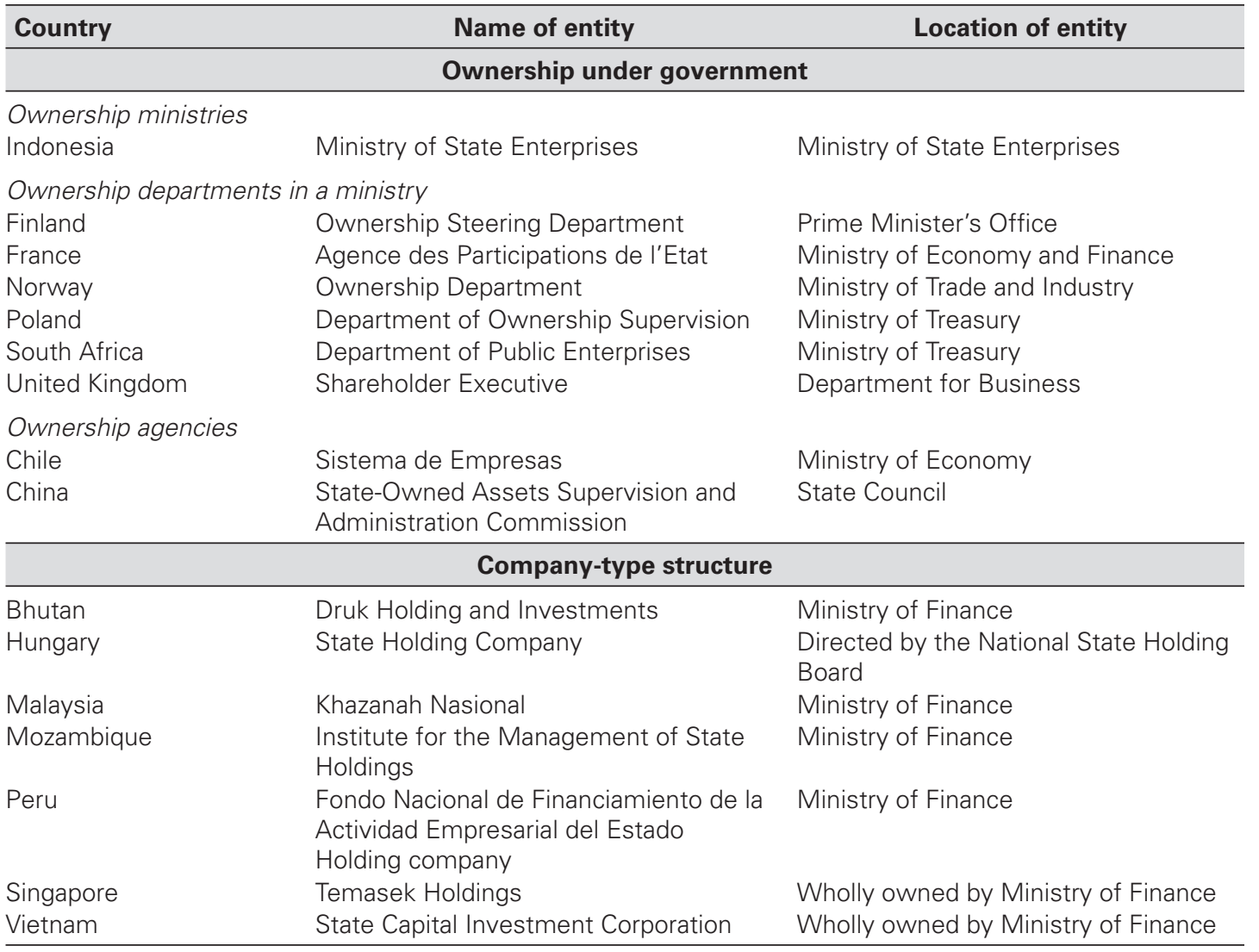

Source: Official websites and annual reports.

of finance. Several reasons favor the finance ministry as a location for this centralized department. First, the finance ministry often owns the SOE shares and assumes the ownership role by default. Second, its role in tracking the SOE sector as a whole for purposes of financial and fiscal discipline means that this ministry is often the only body capable of providing aggregate SOE information to the government. Third, the finance ministry possesses staff with specialized financial and economic skills. France's Agence des Participations de l'Etat is one example of an ownership department affiliated with the finance ministry (box 3.4). Other examples include Poland and South Africa.

Stand-alone ownership agency. A third model, a stand-alone institution or specialized ownership agency, may be established under the direct control 
BOX 3.3

\section{A Separate Ministry for State-Owned Enterprises in Indonesia}

Before 1998, Indonesia governed SOEs through a dual model, with line ministries and the Ministry of Finance (MOF)-the legal owner of all SOEs, financial and nonfinancial-responsible for SOEs. A 1998 presidential decree separated the state's shareholder and regulatory functions, establishing the Ministry of State-Owned Enterprises (MOSE) as a single ownership entity for Indonesia's 141 SOEs and 18 companies in which the state holds a minority share. In 2000, however, the Ministry of StateOwned Enterprises was dissolved, and oversight of the SOEs was transferred to the Directorate General for SOEs within the MOF, but in August 2001 the new president reversed the decision and reestablished the MOSE, while the MOF created an independent Monitoring and Governance Unit, reporting to both the MOF and the MOSE, to carry out financial monitoring and quarterly compliance with the business plan and performance targets, to evaluate management performance, and to assist in improving corporate governance in state banks (World Bank 2008). The unit was staffed with foreign banking professionals with a mandate to provide objective evaluations of the performance of banks, which proved to be a critical factor in maintaining transparency in the restructuring process and ensuring compliance with the performance targets. The unit also acted as a strategic adviser on a range of operational issues, including governance, business planning, accounting, and privatization. The unit was closed in 2005 , but the MOF retained the right to approve changes in the corporate structure of state banks and to sign the recapitalization agreements, which include business plans and performance contracts, as well as receipts of dividends and revenues from the sale of shares. Supervision of financial SOEs is carried out by financial sector regulators.

The ministry's main goal is to sustainably enhance the value of SOEs through corporate mechanisms. Toward this end, it develops government policy and programs for SOEs, including strategic development, work culture, restructuring, and privatization. The ministry has several other key functions related to SOEs:

- To propose directors and commissioners of SOE boards based on fit-and-proper criteria.

(box continues on next page) 
BOX 3.3 continued

- To strengthen the succession and selection process for top managers and to enhance their compensation structure.

- To implement a stricter system of setting and evaluating performance goals through the board of commissioners of SOEs.

- To prepare rules and regulations for SOE activities.

- To improve the implementation of corporate governance principles, with annual reviews and key performance indicators.

- To monitor and evaluate SOE performance.

- To improve communications with stakeholders, including line ministries, Parliament, and the public.

- To provide the president with suggestions on how to improve SOE performance.

Since its establishment in 2002, the ministry has been taking steps to ensure implementation of good corporate governance in SOEs. It began by integrating corporate governance principles in Law 19/2003 on SOEs, including corporate governance in the key performance indicators of SOE management. With the assistance of MOSE and government auditors, SOEs carried out voluntary corporate governance assessments and reviews. In 2003, a corporate governance adviser was appointed to the minister of SOEs. In 2005, the mandatory signing of integrity pacts for new SOE directors and commissioners, a ministerial decree on director and commissioner remuneration, and the laying of the foundation to facilitate whistleblowers took place. In 2008, the fit-and-proper criteria for directors were reformed to make professionalism count more than political background. This change was accompanied by further reform in management remuneration and the mainstreaming of sound risk management in all SOEs.

A 2010 assessment found that of the 142 SOEs, 40 percent had properly implemented corporate governance requirements and another 26 percent had sufficiently implemented the minimum requirements. About 10 percent of SOEs had poorly implemented corporate governance.

Source: World Bank 2008; Fitriningrum 2006; Abubakar 2010; Trihargo 2011. 
BOX 3.4

\section{The Mission of the French Government Shareholding Agency}

France's Agence des Participations de l'Etat (APE) describes its role across four separate parameters:

- A dedicated shareholder. The various functions performed by the government in its relations with state-owned companies are potentially conflicting: it has to act as a shareholder, a customer, or a regulator. In an open and competitive environment, it is necessary to make a clear distinction between these main aspects and to better identify the shareholder activity. The APE has been created to address the shareholder role within the legal framework and in accordance with government guidelines. Its main task is to optimize the value of government assets. The APE coordinates with other ministries to determine the global strategy and provide guidance for the state as a shareholder.

- An effective shareholder. The APE is the main adviser of the Economy Ministry on all matters concerning the government's position as a shareholder. This responsibility covers the main aspects of a company's life cycle: strategy, investments and financing, mergers and acquisitions, and equity transactions.

- A transparent shareholder. The APE has to be transparent when dealing with other ministries, the Parliament, and citizens. It achieves this transparency by presenting the combined accounts of the main government-controlled entities that fall within its scope, regardless of their legal structure.

- An efficient shareholder. To be successful, companies need a professional shareholder they can deal with. The APE is a privileged and regular partner of company directors, focusing on three goals: maintaining transparent and smooth relations with the companies based on a true strategic dialogue, improving their governance, and developing the government's capacity to act as an effective shareholder able to anticipate and make adequate proposals.

Source: Agence des Participations de l'Etat, http://www.ape.minefi.gouv.fr. 
of the executive branch. For example, in 2003 the Chinese government established the State-Owned Assets Supervision and Administration Commission (SASAC) as a special ministerial institution directly under the State Council. SASAC now exercises the ownership functions for many, but not all, Chinese SOEs (box 3.5). Other examples include Chile's Sistema de Empresas (SEP), although some large SOEs stand outside this structure.

\section{BOX 3.5}

\section{A Specialized Ownership Agency in China}

Created in 2003, China's State-Owned Assets Supervision and Administration Commission consolidated the ownership and management of some 200 large, centrally owned state enterprises under a single authority. The total assets of these SOEs account for more than 50 percent of the state's nonfinancial assets. Other SOE assets, including financial institutions, railroads, and the postal system, are mainly held by line ministries.

The establishment of SASAC separated the state's policy-making and regulatory functions from its role as owner and investor. While SASAC exercises the state's ownership rights, related government departments undertake the other functions. SASAC carries out the investor's responsibilities, enjoys the owner's equity rights, and assumes related legal obligations and liabilities. The SOEs in its portfolio operate independently under its supervision and management. SASAC's ownership responsibilities include monitoring, supervising, and enhancing asset value; guiding and promoting the reform of state enterprises; designating the supervisory boards of some large SOES on behalf of the state and managing the boards; appointing, removing, and evaluating the senior management of enterprises and formulating compensation policies for management; improving the corporate governance practices of SOEs; and drafting laws, regulations, and related rules on the management of SOEs.

To help manage the transition from central control to a marketoriented economy, SASAC is also involved in restructuring and privatizing SOEs. It approves mergers and sales of stocks or assets and drafts laws related to SOEs. It has the right to collect a portion of the dividends of the SOEs under its control and thus has the means to implement its restructuring plans. SASAC is also responsible for nonshareholder 
BOX 3.5 continued

functions such as total overhead control, certification of legal counsel in SOEs, and safety inspection.

When SASAC was created, insider control was perceived as one of the SOEs' most serious flaws. In 2005, to resolve this issue, SASAC began establishing boards of directors in a select group of wholly owned enterprises, on a pilot basis. These outside board members came mainly from academia and retired SOE leadership. SASAC's intent was to establish checks and balances between the board and the senior management. While board chairs and CEOs are still appointed by the Organization Department of the Party Committee, the senior executives and board members of all but the largest SOEs are appointed directly by SASAC.

Some of SASAC's practices are said to limit the authority and impact of SOE boards. For example, SASAC sets dividend and compensation policies and makes significant investment decisions for SOEs. In effect, boards do not have the right to decide a number of important issues.

Source: SASAC, "China State-Owned Assets Management System Reform Entering New Stage," May 2003, http://www.sasac.gov.cn/.

The specific mandate and functions of government ownership agencies vary by country but typically include the following roles for companies within their scope:

- Contributing to the development of laws, regulations, and policies covering SOEs

- Assisting or managing the board nominating process

- Monitoring financial and operational performance

- Monitoring and (potentially) recommending SOE remuneration levels

- Monitoring regulatory compliance

- Coordinating activities with other government agencies

- Providing training programs

- Preparing for shareholder participation at annual shareholders' meetings

- Promoting and guiding SOE reform

- Maintaining consolidated information and reporting on company performance

Ideally, the ownership agency should also manage the state's minority share interests, for example, when the state holds a minority position in previously privatized companies. These responsibilities would include 
nominating directors (where possible), reviewing disclosure and reporting, establishing a new expectation that the unit receive disclosure from all companies with a significant ownership position, making recommendations to the shareholding minister in the event of rights offerings, and taking action as problems arise.

Ownership agencies require the necessary staffing and resources for carrying out their objectives successfully. The number of companies in the portfolio determines the number of staff. Many staff are recruited from outside the government to bring the appropriate financial, legal, and corporate skills and, preferably, private sector experience. Often, these ownership agencies also have access to outside advisers and experts with commercial knowledge and experience.

Company-Type Structures. A number of countries have created companytype structures to oversee and manage their SOEs. These entities have a separate legal identity and their own governance bodies, including a board of directors and a chief executive officer responsible for investment, divestment, and business decisions. Broadly, company-type structures fall into two broad categories, although they have similar characteristics: (1) a holdingcompany structure responsible mainly for managing the assets in the portfolio; and (2) an investment company structure that also acts as the government's strategic investor.

Holding companies. The Hungarian State Holding Company (MNV Zrt.) is an example of the holding-company structure (box 3.6). It consolidates ownership responsibilities that were previously dispersed among three separate entities. Other examples include Bhutan, which established Druk Holding and Investments as the holding company for its SOEs; Mozambique, which created the Institute for the Management of State Holdings in 2001; and Peru's FONAFE, which was created by law in 1999. These entities typically approve annual budgets, regulate company activities, manage investment income generated from the companies, and develop corporate governance rules.

Investment companies. In contrast to conventional holding companies, government investment companies generally adopt an active role as the state's strategic investor. Investment-company-type structures are found in a few developed and emerging market countries that have betterperforming SOEs and greater institutional capacity. One example is Malaysia, which created Khazanah Nasional as an investment-holding arm of the government (box 3.7). In the case of financial SOEs, a separation of 


\section{A State Holding Company in Hungary}

The Hungarian government established the Hungarian State Holding Company in 2008 by merging three entities that had been involved with SOEs, allowing the emergence of a single-ownership approach for all national assets. The primary goal of MNV Zrt. is to preserve and increase the value of the assets that will remain in permanent ownership. Its primary task is to create a single-asset cadastre, bringing transparency to the actual value of state assets. The minister responsible for supervising state assets-under current regulations, the minister of national development-exercises the rights and obligations of the state as owner, largely through MNV Zrt. The state as owner is embodied by the National State Holding Board, which directs MNV Zrt.

MNV Zrt. is a single-shareholder joint-stock company with nonmarketable shares. Its board of directors can include up to seven members, who are appointed for a five-year term. The power to appoint and recall the chair and members rests with the minister. The management of MNV Zrt. is led by a CEO nominated by the minister and the board. An audit committee controls its operations.

Under the State Assets Act, which provides the structure and conditions for integrated asset management, MNV Zrt. has the following responsibilities:

- Executing the government's and minister's decisions on state assets

- Keeping records on state assets and providing data on the basis of those records

- Making use of, or granting leases on, state assets over which it exercises ownership rights

- Regularly inspecting the management of state assets by their contractual users

- Representing the state in civil law matters related to state assets

- Ensuring that buyers meet the obligations undertaken in contracts of sale

- Assisting in preparing the National Asset Management Guidelines and Program

- Providing services (operation, procurement) with respect to the use of state assets

Source: OECD 2011. 
BOX 3.7

\section{An Investment Company in Malaysia}

As the investment-holding arm of the government of Malaysia, Khazanah Nasional's main objective is to promote economic growth and make strategic investments on the government's behalf. Incorporated in 1993 as a limited-liability company and governed by the Companies Act, Khazanah is a wholly owned entity of the government, entrusted with holding and managing the state's commercial assets and undertaking strategic investments in new sectors and markets. One share is owned by the Federal Land Commissioner and all other shares are owned by the Minister of Finance (Inc.), a corporate body established pursuant to the Minister of Finance (Incorporation) Act, 1957. Khazanah holds investments in more than 50 government-linked corporations (GLCs) in which the government has a direct controlling stake, valued at about US\$25 billion, in a range of sectors, including finance, telecommunications, utilities, communication services, property development, information technology, and transportation. Khazanah's nine-member board, made up of public and private sector representatives, is chaired by the prime minister and assisted by executive and audit committees. The management team consists of professionals with financial sector experience. Khazanah does not participate directly in GLC management. Instead, its main roles are to ensure the appointment of qualified boards and senior management, push through high-quality business strategies, develop key systems and controls (such as governance, risk management, and internal audit), and monitor progress and performance. A main focus for Khazanah is the transformation of GLCs (those in which the government has a direct controlling stake). Khazanah is funded by the retention of returns generated through its investments, as well as by the issuance of bonds.

Since 2004, one of Khazanah's most important tasks has been to improve the corporate governance of GLCs to increase shareholder and strategic value. It acts as secretariat to the Putrajaya Committee on GLC High Performance, an interministerial committee formed to oversee the GLC Transformation Program. The program has taken a number of steps, including replacing senior managers with seasoned professionals, developing key performance indicators, adopting the GLC Transformation Manual (with guidance on corporate governance), developing performance contracts and an incentive system for managers, removing 
BOX 3.7 continued

government officials with a regulatory role from company boards, and requiring all suppliers to bid for contracts.

A clear mandate, combined with operational autonomy, has enabled Khazanah to work closely with government-linked companies on the restructuring process and to recruit and dismiss enterprise managers on the basis of performance. According to a 2008 study, the aggregate annual earnings of the largest GLCs nearly doubled between the start of the program in 2004 and 2006, thanks to improved corporate governance and other reforms undertaken in the companies as the world economy reached its peak. In addition, the total shareholder return of the companies outperformed the Kuala Lumpur Composite Index by 3.3 percent in November 2007, while market capitalization increased by 83 percent. Reflecting its investment focus, the net worth of Khazanah's investment portfolio has shown substantial volatility. It rose by about 60 percent between 2004 and 2008. The 2007-08 financial crisis wiped out nearly all the gains in share value that the GLCs had earned. By the end of 2012, however, the portfolio had recovered, and the net worth of the portfolio had shown a compound annual growth rate of 11.8 percent since the GLC Transformation Program began in 2004.

Source: Khazanah Nasional official website, http://www.khazanah.com.my/; World Bank 2008.

the ownership function (implemented by Khazanah) and the supervision function (implemented by Bank Negara Malaysia) was achieved, greatly reducing the potential for conflicts of interest (World Bank 2008).

Finland and Singapore have also created investment companies with a more hands-off approach, similar to a private equity fund. With the social and policy objectives of SOEs already ensured, continued control over SOEs as policy tools is no longer seen as essential. Even so, the two holding companies pursue different investment approaches. Finland's Solidium Oy is a passive investor for the state's minority shares, with a mission of stabilizing ownership in Finnish enterprises and ensuring a national base of operations in companies in which it has minority holdings. Singapore's Temasek is an active, growth-oriented investor. It has a large, internationally diversified portfolio and intends to have no more than one-third of its holdings in Singapore.

A number of Gulf Cooperation Council (GCC) countries in the Middle East have also delegated the state's ownership rights to sovereign wealth funds. 
Some of these funds operate as units within the ministry of finance or the central bank:

- Saudi Arabia's Public Investment Fund, for example, is formally part of the Ministry of Finance. The fund's mandate is to invest in commercial projects that are wholly or partially state owned, either alone or in partnership with other government agencies. The fund currently manages investments in 37 domestic companies.

- The Investment Corporation of Dubai, formed in 2006 by a transfer of the government's portfolio of investments from the Ministry of Finance, is charged with exercising ownership rights in a portfolio of 25 SOEs (OECD 2012).

- Mumtalakat, Bahrain's sovereign wealth fund, was established in 2006 to discharge ownership responsibilities in all strategic commercial nonoil and gas assets (box 3.8).

- The Kuwait Investment Authority, established in 1982, now exercises ownership rights in key SOEs entrusted to it by the Ministry of Finance.

As the lead shareholder, investment companies generally do not get directly involved in company management. Their main functions typically include the following:

- Voting at shareholders' meetings

- Nominating or appointing board members

BOX 3.8

\section{A Sovereign Wealth Fund in Bahrain}

Much closer to the model of active and consolidated financial and portfolio management is Bahrain's Mumtalakat Holding Company, created to manage the country's nonoil assets. Mumtalakat is pursuing a much more active and centralized strategy than its counterparts in the region, attempting to rebalance the SOE portfolio through partial divestitures and the restructuring of underperforming SOEs. Its board includes both senior political players and Bahraini nationals who appear to have been chosen for their experience in financial management. This is in contrast with the boards of many of its counterparts, which tend to have a crosssection of senior technocrats and political players with no specialized expertise. Four out of five members of the Mumtalakat board's executive committee are expatriates with specialized financial backgrounds. Source: OECD 2012. 
- Promoting sound corporate governance in portfolio companies

- Monitoring company performance

- Undertaking new investments internally and externally

- Divesting shares of companies

- Subscribing or purchasing equity, debt, or other securities

\section{Ensuring the Effectiveness of Ownership Arrangements}

Ownership arrangements have been steadily evolving toward greater centralization as a way to strengthen the focus on ownership issues and help resolve many of the problems associated with SOE governance. Centralized arrangements are expected to make the state a more professional owner of its assets, to give SOEs operational independence, and to insulate these enterprises from political intervention, while the state maintains an arm'slength relationship with SOEs and resists the temptation to intervene in dayto-day affairs. Centralization is also seen as a way to monitor, consolidate, and disclose information across all government shareholdings, thereby enhancing transparency and accountability.

But experience also shows that no one ownership model or approach is universally applicable and that different starting points may require different reform approaches and sequencing. Moving to a fully centralized model may not always be feasible in the near term because of political opposition, vested interests, or lack of institutional capacity. Concentrating power in large and important SOE sectors may also raise opposition. Concerns about transparency and accountability of the entity itself may also arise, especially in weak governance environments. Ownership arrangements need to be tailored to the country and sector, taking into account the political, economic, and institutional realities; the overall governance environment; and the size, scope, and nature of the SOE sector. The choice of model also needs to be adapted to both the business culture and the government culture.

A pragmatic approach is required for improving ownership arrangements, an approach that combines good practices from developed and emerging market countries and that takes account of social norms, administrative culture, and institutional capacities. Where centralization is not feasible, decentralized and dual ownership arrangements can be improved and put on a path toward greater effectiveness, as discussed above. Creating or strengthening an advisory or coordinating body also provides an option for improving the state's ownership arrangements. Drawing on the experience of GCC countries, a recent OECD report shows that informal 
politics and development of incentive measures can be as important as formal governance structures and that the absence of centralized ownership arrangements and conventional governance mechanisms does not preclude good SOE performance or political accountability (box 3.9).

Simply creating centralized ownership arrangements alone may also be insufficient for ensuring good SOE governance. Irrespective of what type of centralized structure is chosen, a number of risks can still arise:

- Continued interference. Establishing an arm's-length relationship between the ownership entity and its SOEs-and between the government and the entity-can be a significant challenge. Governments may still interfere in operational decisions or impose social obligations that are not clearly defined. The central ownership entity unit may not be shielded from short-sighted political pressures.

\section{BOX 3.9}

\section{Key Lessons from GCC Countries in Achieving Political Insulation}

OECD countries have generally achieved political insulation of SOEs by establishing separate regulators, concentrating ownership in a central agency, and setting up other formal accountability arrangements. The GCC countries, according to a recent OECD report, have achieved some political insulation through a top-down decision to establish structures separate from the rest of the civil service and its administrative culture. This approach has allowed many SOEs in GCC countries to avoid some of the perennial pitfalls of state ownership. What factors have made this possible?

The SOEs have an arm's-length relationship with the administration at large, with high de facto autonomy from line ministries. Rather than being public agencies, all SOEs are incorporated as companies. Many are statutory corporations established by a presidential decree or a special statute that gives them a particular mandate or privileges, including freedom from regulation by line ministries. Accountability is almost exclusively to the top, even if formal ownership is often fragmented among different government entities. The highest-level political authorities accord SOEs political protection against interference by other political actors.

Generous initial capital endowments as well as financial autonomy protect SOE budgets and capital resources. While board chairs are often 
BOX 3.9 continued

ruling family members, the hand-picked executives are usually highly skilled technocrats. Autonomy in recruitment, staffing, and salary systems enables these SOEs to attract top talent. The structure of their senior management is similar to that of Western companies; their accounts are usually audited by international auditing firms (although not always published); and their financial management and corporate finance practices broadly follow international standards.

Some of these structures and practices are informal and difficult to recreate through formal rules alone. They have been established and cultivated by a leadership that is fairly autonomous in its allocation decisions and guards these enterprises against populist economic ideology that might direct public industry as a tool of social engineering and patronage.

While successful SOEs in GCC countries are politically insulated from many pressures originating from line ministries and public administration, they are held accountable for results through clear performance metrics monitored by a limited number of powerful principals. While these arrangements sound similar to those advocated by OECD guidelines, the concrete mechanisms through which a clear mandate and performance orientation are achieved are quite different from the canon of Western corporate governance.

Sources: Hertog 2010; OECD 2012.

- Lack of power and authority. In other cases, ownership entities themselves may be no more than a passive adviser and owner, with little power over SOE managers, especially those directing strategic or high-profile and profitable SOEs, which are often among the biggest companies in a country. Backed by higher-level political principals, SOE managers of such companies can have their own political clout, and together with their political allies, can treat ownership entities as adversaries rather than allies (Naughton 2008). In such cases, without political backing an ownership entity may make slow progress as it confronts opposition from vested interests.

- Lack of capacity. Faced with difficulties in recruiting the necessary skills and obtaining budgetary resources, ownership entities often lack the strategic, financial, and technical capabilities needed to carry out their mandate and responsibilities effectively. 
Experience highlights several steps for minimizing these risks and making ownership entities more effective by:

- Ensuring high-level political support and public attention. In Malaysia, the support of the prime minister lent credibility and strength to Khazanah and the SOE reform program, while also providing some transparency and accountability for results.

- Providing a clear and focused mandate with a high degree of autonomy. A clear mandate helps limit the entity's role to a focused set of ownership rights-such as managing board appointments and providing oversightwhile leaving day-to-day management and decision making to SOE boards and management. Mechanisms have been developed to ensure that ownership entities refrain from interfering in operational matters. In Chile, for example, the ownership entity SEP has been instructed not to "duplicate the work" of SOE boards, while Estonia has put in place specific legislation forbidding SOE boards from taking "instructions" from government (OECD 2011). In Malaysia, a clear mandate, along with autonomy, enabled Khazanah to achieve its performance targets, work more closely with government-linked companies on the restructuring process, and hire and fire enterprise managers on the basis of performance (World Bank 2008).

- Appointing highly qualified professionals. The governance structures of ownership agencies are often composed in a way that allows greater autonomy and political insulation. Recruitment of skilled staff can increase their credibility in dealing with SOE boards and management. Singapore has brought in private sector representatives to the board of Temasek and its portfolio companies to add technical, financial, and legal skills. Alternatively, some entities use specialized consultants while keeping a small permanent staff, as in Sweden. In Malaysia, Khazanah has recruited experienced professionals from the financial and corporate sectors, while government officials with regulatory roles have been removed from the boards of government-linked companies. The incentive structure for the management of Khazanah was also well thought out, with the institution of performance contracts for managers and the linking of compensation to equity stakes in the GLCs so that the incentives of managers and their companies were aligned.

- Developing clear ownership policies and guidelines. An overall ownership policy (as discussed in chapter 2) that sets out the roles and responsibilities of the entities and guides decision making can help protect SOEs from political interference. While implementation of these policies may be ignored in favor of informal decision making, they can still be a step 
forward in increasing consistency and accountability. For example, New Zealand's Crown Ownership Monitoring Unit provides advice to ministers under a statutory framework setting out the roles and responsibilities of shareholding ministers and separating commercial from policy aspects.

- Ensuring dedicated resources and building capacity. When ownership entities are able to recruit skilled staff to carry out their mandate and create a more business-oriented culture, they can increase their confidence and credibility in dealing with SOE boards and management. While ownership entities may face more constraints on attracting and retaining expertise than the private sector, ways are being found to obtain the necessary skills. South Africa's Department of Public Enterprises, for example, embarked on a drive to attract and retain young graduates through its internship and graduate development programs and continued to strengthen internal skills and capacity through training, mentoring, and coaching programs. Financial resources are also critical. In addition to budgetary support, in China and Mozambique, for example, central ownership units are allowed to retain income from dividends and sales proceeds, which provide a source of additional funds to help carry out their mandates.

- Reaching out to line ministries and other agencies. While decision making rests with ownership units, on many occasions they may need to seek advice from line ministries and other agencies to help ensure consistency and maximum impact in implementing reforms. Particularly for banks, a separation of the ownership functions (implemented by Khazanah) and supervision (implemented by Bank Negara Malaysia) functions was achieved, which greatly reduced the potential conflicts of interest when the two functions are jointly executed.

- Building in accountability. Ownership entities generally have clear reporting lines-in some cases, directly to the prime minister, in others to the minister in charge of the portfolio. Preparation and public disclosure of annual reviews and oversight by parliament and audit institutions are additional means for promoting transparency and accountability.

- Monitoring performance of the ownership entity itself. In addition to developing performance-monitoring systems for the companies in the ownership entity's portfolio, some countries have developed performance management systems for the ownership entities themselves. India, for example, has a results framework document for the Department of Public Enterprises for measuring its performance against its key objectives, targets, and performance indicators. Objectives are weighted according to their priority, and for each objective the department specifies the required actions based on policies, programs, and projects, with key performance 
indicators for each based on inputs, activities, outputs, and outcomes. The achievements of the department are rated on a five-point scale from poor to excellent based on the composite score of all indicators. In place since 2009, the system is part of the broader Performance Management System developed for the government of India as a whole. Its goal is to identify the department's main objectives for the year, determine the actions needed to achieve them, and assess the progress. The results are published on the government's website, leading to greater transparency and accountability.

\section{Note}

1. Protecting shareholder value is presented as the overriding objective of state ownership in many countries, while in others it is one in a set of social goals. Its inclusion as an objective is aimed at providing a clear and simple criterion to guide decision making and evaluate the performance of the ownership entity and the government. More specifically, the goal is to improve the performance of SOEs-so as to enhance the value of the state's SOE shares while reducing the fiscal burden of SOEs.

\section{References}

Abubakar, Ir. Mustafa. 2010. "Ministry of State-Owned Enterprises, Indonesia: Towards World Class Corporations.” PowerPoint presentation.

Fitriningrum, Andriati. 2006. "Indonesia Experiences in Managing the State Companies." Presentation at OECD-Asian Roundtable on Corporate Governance of State-Owned Enterprises, Singapore, May 15.

Hertog, Steffen. 2010. "Defying the Resource Curse: Explaining Successful StateOwned Enterprises in Rentier States." World Politics 62 (2): 261-301.

National Audit Office. 2007. The Shareholder Executive and Public Sector Business: Report by the Comptroller and Auditor General. London: National Audit Office.

Naughton, Barry. 2008. SASAC and Rising Corporate Power in China. China Leadership Monitor 24. Palo Alto: Hoover Institution, Stanford University.

OECD. 2010. Policy Brief on Corporate Governance of State-Owned Enterprises in Asia: Recommendations for Reform. Paris: OECD.

- 2011. State-Owned Enterprise Reform: An Inventory of Recent Change. Paris: OECD.

- 2012. Towards New Arrangements for State Ownership in the Middle East and North Africa. Paris: OECD.

Rudolph, Heinz P. 2009. "State Financial Institutions: Mandates, Governance, and Beyond.” Policy Research Working Paper 5141, World Bank, Washington DC. 
Scott, David. 2007. "Strengthening the Governance and Performance of State-Owned Financial Institutions.” Policy Research Working Paper 4321, World Bank, Washington, DC.

Trihargo, Gatot. 2011. "Good Corporate Governance Implementation in Indonesia's State Owned Enterprises.” Power Point Presentation. Ministry of State-Owned Enterprises, Republic of Indonesia.

World Bank. 2008. "Lessons in Reforming State Ownership of Financial Institutions: Three Country Case Studies.” Unpublished manuscript. World Bank, Washington, DC.

- 2010. "Corporate Governance of Central Public Sector Enterprises: Republic of India." Finance and Private Sector Development vice Presidency, World Bank, Washington, DC. 



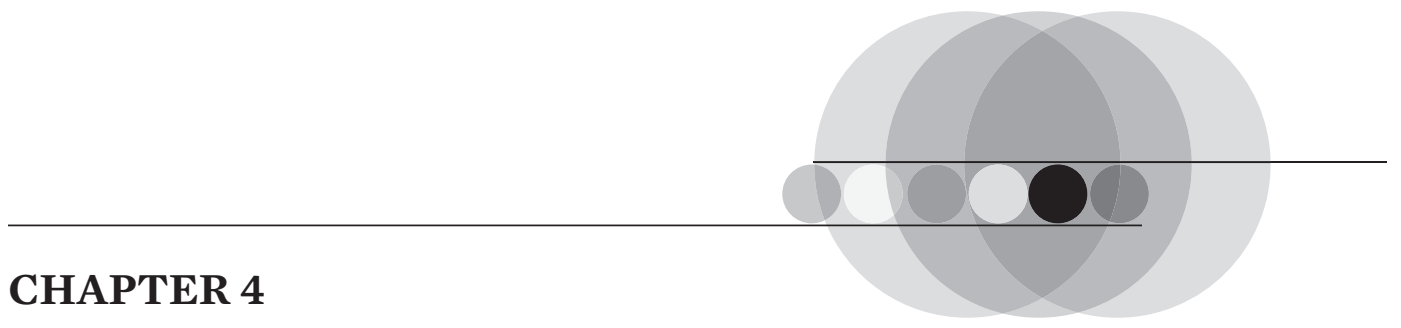

\section{Performance Monitoring}

In many countries, reforms of state-owned enterprises (SOEs) show that effective performance monitoring-a key ownership function of the state as owner-can drive both financial and nonfinancial improvements. A strong performance-monitoring regime sets objectives and targets that provide clarity to SOE boards and management on the expectations of government (as principal). Clear goals, accompanied by measurement and accountability for results, establish a framework in which the SOE board can set and execute strategy with an appropriate degree of autonomy, while providing ownership units (and government generally) with sufficient assurance that SOEs will be held accountable for their performance.

This chapter describes key elements involved in creating a performance-monitoring system. ${ }^{1}$ It covers the following:

- Objectives of performance monitoring

- Obtaining baseline information on SOEs

- Setting mandates, strategies, and objectives

- Structuring performance agreements

- Developing performance indicators and targets 


\section{Key Concepts and Definitions}

A performance-monitoring system refers to the institutions, processes, and documents that government uses to monitor the financial and nonfinancial performance of SOEs. Performance monitoring involves three key elements: setting mandates, strategies, and objectives; structuring performance agreements between SOEs and government to monitor how well each SOE performs; and developing key performance indicators and targets.

Performance objectives and targets for SOEs, often contained in formal documents agreed to by the government and the SOE, can include both highlevel statements of the SOE's objectives and more detailed agreements specifying annual or multiyear performance measures. High-level objectives are often referred to as $S O E$ mandates. The Organisation for Economic Co-operation and Development (OECD) defines SOE mandates as "simple and brief descriptions of the high-level objectives and missions of an SOE in the long run" (OECD 2010, 19). Mandates are generally defined by the state as owner, not by the company.

Specific performance agreements established by the government and the SOE go by different names in different countries, often reflecting their different form or legal status. Examples include statements of corporate intent, performance contracts, memorandums of understanding (MOUs), statements of expectations, shareholders' letters, letters of agreement, and business plans.

Performance indicators are the metrics used to communicate performance expectations and to evaluate performance against expected results. Using these indicators, an organization can track its results against its targets, celebrate its successes, and quickly identify potential problems. "Lagging indicators" are those that show the organization's past success in achieving expected outputs or outcomes, while "leading indicators" predict future achievements.

\section{Objectives of a Performance-Monitoring System}

Monitoring SOE performance is a core function of the state as owner to ensure transparency and accountability in the use of public funds. As shareholder, the government is required to manage its SOE investments as well as it can in the best interests of the country and taxpayers and is accountable to parliament for SOE performance. Such monitoring is central to ensuring that these enterprises produce the best possible outcomes, similar to the way equity holders are responsible for investments in private sector companies. Indeed, governance is about managing risk on the owner's behalf. In the 
absence of proper monitoring, boards and management may embark on investments and activities outside the agreed-on core business to the financial detriment of the owner.

The state's ownership entity(ies) must see that each company meets the targets and objectives set for it and must take action if it is not. A fundamental challenge for ownership entities in creating performance frameworks is that SOEs are usually established (and continue in government ownership), because they have both commercial and noncommercial objectives. In many cases, the nonfinancial goals will carry financial costs, making it difficult for the board and senior executives of the SOE to resolve their competing priorities. Information asymmetries can also allow managers to conceal poor performance or exceed their mandate. These asymmetries can also affect the negotiation and monitoring of performance, since inside managers have a far better understanding of the performance and operations of their company than external reviewers.

A sound performance-monitoring framework addresses these inherent tensions by explicitly identifying the core financial and nonfinancial objectives of the SOE and by spelling out the government's priorities for the various strategic objectives of each SOE. In this process, the ownership unit must develop appropriate performance targets that reflect these priorities.

Chapter 3 described a tendency toward greater centralization of authority for SOE ownership functions. By integrating the views of the various government stakeholders and imposing a uniform approval process, centralization can significantly improve the coordination and efficiency in defining company mandates. In addition, a centralized ownership unit may develop cross-cutting objectives for its SOE portfolio as a whole. The aim of a performance-monitoring framework is to ensure the accountability of the SOE board and senior management in meeting financial and nonfinancial performance benchmarks. It also indirectly helps define the objectives and responsibilities of both government and SOEs. Developing such a framework requires common and clearly understood principles of accountability and governance based on several factors:

- Obtaining baseline information, to create the necessary building blocks for developing a performance-monitoring system.

- Setting mandates, strategies, and objectives, to reflect the overall policy goals of government in its ownership of each company.

- Structuring performance agreements, to facilitate periodic performance monitoring of the SOE by an ownership unit.

- Identifying and developing key performance indicators, to measure and evaluate results. 
Where successful SOE performance-monitoring systems have been put in place, they have evolved over many years, based on the implementation of good corporate governance policies and procedures, clear and focused board accountability, an ownership unit familiar with both the SOEs and the sectors in which they operate, and shareholders who have followed expert advice. Implementing the attendant organizational and institutional systems requires reasonable capacity and close coordination between ownership entities and companies. The sophistication of planning and performance analysis should be commensurate with the size and complexity of SOEs and their businesses.

\section{Obtaining Baseline Information}

Before creating a more comprehensive performance-monitoring system, the ownership entity should first build baseline information on its SOE portfolio and remove bottlenecks to financial reporting by companies in the portfolio. This undertaking usually involves the following tasks:

- Building a list of the companies in the portfolio. Most countries find it difficult in the beginning to construct a comprehensive list of the companies and assets owned by government. This task can be particularly difficult when moving from a decentralized system to a more centralized one or when a coordinating body is created. The ownership entity should first work with ministries to identify the companies and get a sense of their legal and operational status (operating, closed, in liquidation, and the like).

- Classifying the companies based on their legal and operational status. Many ownership entities monitor several types of organizations-from large companies wholly owned by the government to budget-dependent social service agencies, regulatory bodies organized as companies, and joint ventures with private companies. Early on, it is important to begin placing companies in different categories according to their complexity and needs. As a starting point, organizations can be grouped into three types:

- Commercial companies are those that derive the majority of their revenues from commercial sources. These companies can be further divided into minority owned and majority or wholly owned.

- Policy-oriented companies are those that have broader developmental and noncommercial goals, such as the delivery of certain infrastructure services.

- Budget-dependent agencies are those that receive the majority of their revenues from government budgets. Such companies can be further divided, for example, into social service agencies and regulatory bodies. 
- Carrying out a "SWOP" analysis for key sectors. A SWOP analysis involves assessing the strengths, weaknesses, opportunities, and problems of a company.

- Collecting key documents about the companies. This task requires building files of company information, including annual reports or financial statements; financial reports to line ministries; founding company laws, charters, or constitutions; reports from the supreme audit authority or state auditor; budget documents detailing payments from the government budget to the company and dividends paid by the company to the government; information on credits outstanding to the company (especially from government entities); and any other information available. Understanding the financial information and trying to reconcile conflicting information from different sources are important parts of the process.

- Developing and completing a basic template of important data. A basic template of key data on each company in the portfolio should include some specific facts: company name, sector, legal status, percentage of state ownership, number of employees, assets, revenues, profits, dividends and taxes (if any) paid to the government, and subsidies paid and exemptions granted to the company by the government.

- Drafting a short report on the portfolio. The ownership entity ideally should be able to produce a few pages that summarize the key information collected from all SOEs. These data should be periodically updated and published.

- Getting to know the companies. A surprising number of ownership entities (and especially coordinating bodies) do not meet with boards and management of the companies in their portfolio and thus know little about them or about the sectors in which they operate. An initial meeting should have basic goals: to introduce the ownership entity and its role and mission, to identify key points of contact in the company for future communication, and to address initial questions about critical missing information, especially financial reporting.

- Developing a strategy to address constraints on financial reporting and auditing. Many companies (especially in low-income countries) find it difficult to produce financial statements on time and have them audited in a timely manner. The ownership entity should make basic financial reporting a top priority in the companies, resolve any legal or resource constraints on timely auditing, and work toward a goal of 100 percent compliance with financial reporting requirements.

The above steps will help lay the groundwork for a more comprehensive performance-monitoring system: (1) by capturing financial data from SOEs; 
(2) by prioritizing the SOEs on which to focus resources during the monitoring process; (3) by building expertise within an ownership unit on the portfolio companies, their industries, and performance monitoring; and (4) by establishing formal and informal lines of communication with SOE management, boards, and external stakeholders.

Achieving the above tasks requires that the ownership entity assign staff to monitor the portfolio. How staff are assigned will depend on the number of companies in the portfolio and the number of staff available. As a rule of thumb, one staff member can probably cover and understand 10 portfolio companies (fewer, if the companies are large and complex).

\section{Setting Mandates, Strategies, and Objectives}

A large part of preparing performance agreements is to set company mandates and strategies. Clearly defining the mandate of each wholly owned company is necessary for defining accountability, for determining the scope of public services or other special obligations, and for forming a basis for more specific targets for the company's operations. SOE mandates usually define the sector of operations and main line of business and in some cases may lead to multiple and competing mandates and goals (box 4.1). They may also specify broad goals or constraints on financial sustainability. And they should include a description of the scope of public services and other special obligations such as employment commitments. Mandates thus explicitly identify the combination of commercial and policy objectives. Formalizing and incorporating them into the strategysetting process can reveal any inherent contradictions so that they can be addressed.

Based on its mandate, each SOE needs to develop its own strategy, subject to board approval (and explicit or implicit approval of the ownership entity). A clear mission, vision, and strategic plan can provide conceptual clarity for both management and employees. Clear strategies help managers make decisions and trade-offs that are in line with the overall direction of the company. They also provide a basis for measuring its performance.

Formally addressing the risk considerations of business plans and projected growth areas, the adequacy of existing functions for controlling internal risks, and the need to correlate risk management and internal audit capacity with growth can strengthen strategic planning in state-owned financial institutions. Likewise, success and performance indicators should reflect the risk-reward trade-off and the return against allocated capital along key business lines. 
BOX 4.1

\section{Mandates in State-Owned Development Banks}

By definition, state-owned development banks have noncommercial, or social, mandates and thus multiple (and potentially competing) goals. Besides profitability, development banks have mandates that define their business model (based on lending to specific sectors, regions, and types of borrowers) but that conflict to some extent with the basic goal of financial sustainability. The absence of clear goals makes it difficult to assess managerial performance, reduces incentives to maximize efficiency, and leads to potential capture of the SOE and its resources by management. Governments may also abuse this discretion, meddling in the bank's affairs for political gain under the cover of their different policy goals and mandates.

A 2011 survey of development banks indicates that they were established with a wide range of policy or developmental mandates. Surveyed development banks fall into two groups: institutions with a narrow and specific mandate that explicitly refers to target sector(s), customers, or activities; and institutions with broad mandates formulated in general terms without reference to any particular sector or activity. Examples of these types of mandate are "to promote the country's economic development" or the "well-being of citizens." The survey published several findings relevant to SOE mandates:

- Fifty-three percent of institutions surveyed had specific policy mandates, including mandates to support the agriculture sector; small and medium enterprises through their lending, guarantee, or advisory services; export and import activities; or housing, infrastructure projects, and other sectors. The other 47 percent had broader legal mandates with a wider range of activities and sectors.

- Most institutions surveyed (92 percent) target small and medium enterprises; 60 percent target large private corporations; 55 percent target individuals and households; 54 percent target other state-owned enterprises; and 46 percent target private financial intermediaries.

- Some institutions are legally obliged to produce a minimum return on capital, such as maintaining real capital constant (earn a return not lower than inflation), achieving a rate of return not lower than the government's long-term borrowing cost (the Business Development

(box continues on next page) 
BOX 4.1 continued

Bank of Canada, for example), or earning an explicit return on capital (ranging from 7 percent to 11 percent, annually).

Broad mandates provide the flexibility to finance a wide range of activities and sectors the government deems important. However, if not properly managed, broad mandates can lead to a loss of effectiveness, as institutions become subject to different and competing demands from various ministries and other government institutions or they have "mission creep" and take on diffuse tasks. When the development bank's mandate is given only in broad general terms, senior government officials or elected politicians have more room to influence its direction and activities. Unless the bank's institutional framework is strong enough to withstand undue political pressure, it can become vulnerable to political interference or be captured by interest groups that exert pressure to take excessive credit risks, thus causing future financial losses for the bank. Broad mandates can also encourage SOEs to compete with privately owned banks.

Source: de Luna Martinez and Vicente 2012.

As noted above, SOEs face special challenges in developing clear and coherent strategies, in particular, because they often have conflicting objectives that are difficult to reconcile and sometimes given informally. Formalizing objectives and incorporating them into the strategy-setting process will bring to light any inherent contradictions transparent so they can be resolved.

Objectives communicate the purpose of the SOE and the state's expectations for performance. Clarity and transparency of objectives are important. Where there are multiple objectives and trade-offs among policy, regulatory, and commercial objectives, they should be clearly identified and stated. Ownership entities often consult with sector departments, ministries of finance, and the cabinet to set the objectives and strategy for the state as shareholder, combining optimization of shareholder value and achievement of wider socioeconomic objectives.

The complexity of the strategy depends on the nature of the business, the size of the company, and the depth of its competition. Large companies can benefit from engaging consulting firms that specialize in national or 
international strategy, as long as the firms are given clear terms of reference. Most important is that the strategy for SOEs be a written one, updated as necessary, and closely linked to the performance management process so that the SOEs' progress can be measured. Also important is that strategies be realistic and internalized broadly throughout the company.

The process of developing a strategy involves both the board and the ownership entity. The board should have ownership of the process so that it is accountable to the ownership entity for the strategy. According to good practice in corporate governance, each governance body has a role to play (see the discussion of board responsibilities in chapter 6). Management is responsible for developing the strategy. ${ }^{2}$ The board is responsible for approving the strategy and monitoring its implementation. Last, the ownership entity is responsible for monitoring the company's performance and its adherence to its strategy and other commitments in line with the general objectives the state defines for each SOE. In practice, significant changes in strategy (especially in large and important companies) will require the approval of the government owners and stakeholders.

The strategy is expected to include goals and specific objectives. The overriding goals are to ensure the SOE's performance and long-run financial sustainability and to meet the performance objectives set by the owner. Objectives are then measured against key performance indicators and targets. Objectives for SOEs should be clear and realistic. Guidance should be provided on trade-offs, and management should have limited discretion in balancing different objectives.

\section{Structuring Performance Agreements}

Once the mandate is agreed, an ownership entity can develop a framework for communicating the government's expectations for SOE performance to each SOE and to the public. Performance agreements are widely used for this purpose. While performance agreements have long been in use, today's agreements differ in many ways from performance contracts of the past (box 4.2). Whereas in the past both boards and ownership arrangements could be relatively weak, today, strong boards and ownership entities are better able to reduce gaming and improve the chances of success. For these agreements to be effective, all parties must respect their legitimacy (regardless of their legal enforceability) and follow rigorous, formal procedures both in the initial negotiation and in later ones when any amendments are proposed. 
BOX 4.2

\section{Past Experience with Performance Contracts}

Performance contracts have been used for more than 25 years to improve SOE governance. However, past efforts to impose performance contracting on SOEs generally failed to meet expectations. They were the subject of much study in the 1990s. Shirley noted that "the logic of performance contracts is persuasive, but the reality has been disappointing" $(1998,2)$ and argued that the three conditions for success were rarely if ever met:

- To prevent gaming. Incomplete contracts failed to anticipate important events, and information asymmetries gave management the upper hand.

- To provide incentives. Performance incentives were often missing.

- To have credible impact. Contracts may not have been respected by signatories.

There were at least two main issues that undermined these contracts. First, performance agreements were not negotiated with the board. Instead, they were considered to be agreements between the state (or a state institution such as a ministry) and the SOE or, alternatively, between the state and an individual (usually the chief executive officer). The board was an afterthought and often viewed as an extension of the ministry, not as a separate body that oversaw management and worked in the interest of the company. Strong boards are important to reducing gaming.

In addition, ownership entities were (and often are) weak, relative to both the rest of the government and the SOEs. As a result, no agent was in place to take action against SOEs that failed to comply with performance contracts. And no government actor worked to support the company when governments failed to comply with their side of the deal.

Muir and Saba (1995) described further technical failures, suggesting that contracts were often too complex and that external performance monitoring was ambiguous. The World Bank pointed out that even if the problems of gaming, incentives, and impact could be resolved, the result might still be poor because the goals were often written in a way that created conflicting incentives: "Certain targets, such as revenue growth, could create perverse incentives, leading, for example, to overinvestment in unprofitable businesses" (Robinett 2006, 16). A corollary is that performance contracts may create distortions through a subjective weighting of different objectives. For instance, a loan officer might 
BOX 4.2 continued

be rewarded for generating credits while not being rewarded for a proper assessment of creditworthiness.

The fundamental weakness of performance contracting is that compliance can have adverse financial and political consequences for other parts of the state. Shirley (1998) cited examples from Ghana, India, and Senegal, where performance contracts required the government to pay for the electricity consumed by SOEs but the government refused to force public entities to pay their bills. Examples of government refusal to comply in the face of political consequences are common. Thus both managers and governments have powerful incentives to ignore the terms of contracts. In some countries, frustration on both sides caused performance contracting to fail.

Despite this checkered history, carefully constructed performance agreements that are part of a broader package of comprehensive reforms can improve efficiency if the government is politically prepared to make tough decisions and stand by them. The importance of political support is corroborated in China and in reports of early successes with performance contracting in Kenya. These successes may have less to do with the technical precision of the contracts than with establishing strong boards and ownership entities to make the process work. A key lesson from experience is that performance contracting is not a panacea: it is only a tool to help implement a full accountability framework.

\section{Structure of Performance Agreements}

A performance agreement describes the expectations and specific objectives agreed to by the ownership entity and the SOE board. It will typically include the following elements:

- Its mandate and the scope of activities that the company (including subsidiaries) will undertake. As noted above, the mandate defines the core and noncore activities of the business that the board is accountable for delivering. The mandate provides two-way benefits: it serves as a constraint on the company, imposing discipline against undertaking nonrelevant activities that may not be in the best interests of the owner. It also protects the board and management from being asked to undertake activities that are inconsistent with the core business. The performance agreement should avoid confusing the roles of owner and manager and 
give managers clear authority and responsibility for achieving output targets and outcomes.

- A short description of the company's vision and strategy. To understand and manage performance, each SOE needs to develop and adopt its own strategy. The performance agreement should be based on and incorporate the company's strategy, consisting of goals and a cascading set of objectives.

- A clear description and explicit financial cost estimate of the company's noncommercial objectives, such as access, coverage, and affordability for low-income consumers. This provides the state and the public with an overall understanding of the cost of meeting social objectives. When companies have significant policy objectives, the ownership entity needs to consult with line ministries or the ministry of finance to balance commercial and noncommercial objectives.

- Financial and nonfinancial performance indicators, as well as targets for those indicators, to measure the performance of the company against its strategy. Performance measures can be expected to grow in sophistication over time.

- Frequency and procedures for reporting. When not otherwise described in law or regulation, the performance agreement should specify the reporting requirements and deadlines for the SOE.

- A statement describing the dividend policy. Dividends are driven by an SOE's capital structure, profitability, and estimate of future capital expenditure. A dividend policy enables the ownership entity to better control SOE expectations, since a "generous" balance sheet may encourage boards to extend beyond their core business and preferred risk profile.

\section{Negotiating Performance Agreements}

Before the performance agreement is finalized, the ownership entity and the SOE must discuss it and negotiate its contents. In countries where this process is fully developed, such as India, Malaysia, and South Africa, agreements and targets are produced annually. In many countries, the performance agreement is made public and presented to parliament to establish the links in accountability. It is crucial that the government's expectations of the SOE be formally, clearly, and publicly communicated.

To properly negotiate the agreement, the ownership entity normally has good knowledge of the industry based on research, experience, and dialogue with the company. It should also seek help from consultants or other experts as needed. 
How performance agreements are prepared and negotiated varies among countries, as shown by well-known performance-monitoring systems in India, New Zealand, and South Africa. These frameworks differ in important ways, in part because of differences in the structure of the government's ownership entity:

- Level and style of negotiation. In South Africa (and many other countries), the performance agreement is much more an "expectations document" than an effort to establish a formal contract. The agreement is (at least to some extent) imposed by the ownership entity on the company. In contrast, in New Zealand (and many other countries) the spirit of the law is much more "bottom up," with a negotiation between the company's board and the ownership entity at the core of the process.

- Role of independent experts and outside committees. Some countries use outside experts or committees for the evaluation process. In India, the MOU system uses task forces or committees-composed, at least in part, of outside experts-to increase the independence of the process and to introduce more sector expertise (box 4.3). In Thailand, the process of monitoring is contracted to an institution outside the government. Whether this approach leads to better outcomes than one in which the ownership entity employs more sector expertise itself is not clear.

In the Republic of Korea, a business performance evaluation system has been established for public institutions. The system covers about 100 public corporations and quasi-governmental organizations. The Ministry of Strategy and Finance has constituted an evaluation team consisting of about 130 civilian experts-professors, consultants, and accountants-that is set up every February to carry out evaluations between March and June that are then confirmed through review and resolution by the Public Institutions Management Committee, which was created in 2007. Headed by the minister of strategy and finance, the committee consists of 11 experts appointed by the president as well as vice ministers of responsible ministries. Twenty indicators in three categories are evaluated, including leadership and strategy; management system; and management result. Qualitative and quantitative indicators within each category are weighted and grades assigned. Incentives are decided based on the grade. For public corporations, incentives vary from 250 to 500 percent of the basic salary, based on the grade given. Each individual's incentive will be decided on the corporation's result. For institutions with poor results, the minister of strategy and finance may go as far as recommending dismissal of the CEO, subject to a review of the Public Institutions Management Committee. The system is leading to 
BOX 4.3

\section{Using Task Forces to Help in Performance Management in India}

Centrally owned public sector enterprises (CPSEs) in India are monitored and evaluated through a system based on the "memorandum of understanding" or MOU, a performance agreement negotiated between, and signed by, each enterprise and its administrative ministry. Each MOU sets out objectives, targets, key performance indicators (financial and nonfinancial), and incentive-based rewards.

The MOU system was established in 1986 to improve the performance of CPSEs by increasing their autonomy while holding them accountable for results. The system started with four companies in 1986-87, growing to 143 in 2007-08. Beginning in 2007, the Department of Public Enterprises (DPE) required all CPSEs to have an MOU, either directly with the administrative ministry or, for subsidiaries, with the parent company.

The elements required in each MOU are set by the DPE. These include a mission statement, the objectives of the enterprise, areas where power has been delegated to the enterprise, performance targets, and commitments from the government to the enterprise. In negotiations, it is the performance targets-and the composite score calculated on the basis of them-that appear to be the main focus of participants in the system. The department's guidelines specify targets, with weights assigned to each, based on the broad sector in which the enterprise operates (loss-making companies and those under construction have their own formats). A balanced-scorecard approach is used, with 50 percent of the weight given to financial targets and 50 percent to nonfinancial ones.

The system recognizes that developing and negotiating the agreements are a difficult task, requiring sectoral and financial expertise in both the company boards and the ownership entity. Therefore, negotiations are arranged by the DPE and facilitated by 12 "task force syndicates" organized by sector. Each enterprise is assigned to a task force, which approves the MOU and evaluates how well the enterprise performed against its targets. Each task force includes a convener and six members-retired civil servants, public sector executives, management professionals, and experienced independent members. The task forces were formed to bring both technical expertise and independence to the process (no current 
BOX 4.3 continued

government member can serve on a task force). Final MOUs must be approved by a high-powered committee, which also assesses the performance of the enterprises and line ministries in meeting their commitments.

Performance is evaluated by comparing achievements against the agreed annual targets. It is measured on a five-point scale, ranging from excellent (1) to poor (5) for each target area. Most enterprises typically receive scores between 1 and 2 . Performance incentives include monetary payments based on the scores, excellence awards for the bestperforming enterprises, and excellence certificates for those with a final score of 1.5 or better (awards have been presented in recent years by the prime minister). The score is also taken into account in the evaluation and bonuses for managing directors and other senior officers. The government has accepted the recommendation of the Second Pay Revision Committee that the MOU performance evaluation be one of the basic criteria for establishing performance-related pay and variable pay, provided CPSEs sign MOUs with their parent ministries or holding companies.

The DPE has been introducing new initiatives in recent years to make the MOU system more dynamic and robust. These include, for example, simplification of human resource indicators, negative markings by the task forces for corporate governance noncompliance of a serious nature, and assignment of adequate weight to physical targets. The DPE has constituted a working group headed by the chairman of the task force to review the existing MOU system. The recommendations of the committee are under examination.

Source: World Bank 2010; DPE 2013.

fierce competition among companies and a general improvement in performance. A management evaluation manual offers basic guidelines for companies.

\section{Monitoring Performance Agreements}

Monitoring company performance against the agreed company objectives and performance targets as set out in the performance agreement is generally done on an annual basis; but for more important portfolio companies 
more regular monitoring (bi-annual or quarterly) may be warranted. The key to implementing a periodic monitoring framework is establishing suitable performance indicators and targets, as discussed above.

The monitoring process can be streamlined by requiring SOEs to provide standard-form financial and nonfinancial data. These forms have varying degrees of complexity, from simple spreadsheet-based templates to dedicated online data entry portals. More sophisticated systems can facilitate data analysis by identifying trends, producing cross-sector or intertemporal analysis, and generating aggregate reports. However, where more complex uses of the data are not required, the risk of elaborate data entry systems is that they fall into disuse.

Where possible, the data required should conform to the existing data requirements imposed on the company. For instance, requirements should preferably align with the relevant accounting standards that the SOEs must adopt for their financial statements.

In general, periodic monitoring instills a culture of accountability that serves multiple aims:

- Initially, the ownership entity can ensure that the SOE is completing all periodic reports and actions (for example, preparation of annual financial statements and external audits) and delivering them on time.

- All variances between the actual financial and nonfinancial results and the agreed results (as set out in the relevant performance agreement) should be documented.

- SOE management can be asked to document reasons for any unexpected variances, or, alternatively, the principals of the SOE can give the explanations in face-to-face meetings with the ownership entity.

- Large or unjustified variances from planned results should be reported up through the system. As a result, for instance, the major issues arising from the performance review might be discussed between the chairman of the SOE and the head of the government ownership unit. Depending on the national accountability structure, significant issues might be reported to the minister or to a legislative oversight committee.

- Variances may give rise to consequences under the performance agreement.

- Periodic public disclosure can be made of SOE performance against the agreed objectives or relevant benchmarks and can act as a strong incentive for managers and boards to improve the performance.

In Thailand, SOEs have performance agreements with key performance indicators and targets, and the State Enterprise Policy Office (SEPO) monitors these with the Thailand Rating Information Service, which has 
been contracted by SEPO for this purpose. SOEs are required to disclose their key performance indicators in state enterprise reviews, which also include a statement of direction, financial data, and operations under government policies. These are available on the SEPO website.

\section{Developing Performance Indicators and Targets}

The feedback provided by performance indicators allows an organization to improve itself continually. While there are many ways to develop indicators and targets, each SOE's objectives and targets should align with its overall mandate and with the strategy it has adopted to fulfill that mandate. It is also advisable that performance indicators include both financial measures (capturing sales, profit, and debt) and nonfinancial ones (either those that predict future nonfinancial performance or that are particularly important to the company's strategy).

Key performance indicators need to be carefully selected to ensure that each directly drives a strategic objective. When designing indicators and targets for the broader performance agreement, the ownership entity should have the opportunity to engage the required expertise.

\section{Effective Performance Indicators}

A large literature addresses the use of key indicators for performance management. Experience from both the public and the private sector suggests a basis for developing high-quality performance indicators for managing SOE performance. Several of these appear in New Zealand's guidelines for SOE performance indicators (box 4.4).

Other effective performance indicators involve company strategy and objectives, incentives, benchmarking, management performance, tracking, and auditing:

- Indicators should be linked to company strategy and objectives. The key is to identify broad dimensions of performance that are important and then find specific measures or indicators that might reflect performance for each of these dimensions. The quality of the performance assessment will depend on the completeness and comprehensiveness of the indicators. The combination of all indicators should reflect the overall priorities reflected in the objectives.

- Indicators should be SMART-Specific, Measurable, Achievable, Resultsoriented, and Time-based. Indicators should be based on objectives that 


\section{BOX 4.4}

\section{Guidelines for Performance Agreements and Indicators in New Zealand}

In New Zealand, SOEs negotiate a statement of corporate intent with their shareholding minister each year. The company board is required to prepare a draft statement and submit it to the minister for review. The statement should include the company's objectives, specific financial indicators, basic financial policies, and key targets. Performance indicators (financial and nonfinancial) must also have other characteristics:

- Be meaningful for the SOE's business and SOE law.

- Be specific and measurable, with no ambiguity.

- Be timely and capable of being audited, where appropriate.

- Be within the SOE's responsibility or power of control.

- Be consistent with and influence, as appropriate, the SOE's purpose and principles of operation or business.

- Respect commercial sensitivity, where appropriate.

- Encourage and reflect best practice.

- Where appropriate, ensure employee participation in, and ownership of, the indicators.

The board negotiates the draft statement of corporate intent with the shareholding minister formally and informally. It considers any comments on the draft by the minister; then the board delivers the final statement to the minister before the start of the company's financial year. The board can modify the statement through written notice to the shareholding minister as long as it first gives written notice of the proposed modification and considers any comments.

Source: CCAMU 2007.

SOE management can actually control and be held accountable for. Indicators should make it easy to evaluate performance while avoiding complexity and bureaucracy.

- Indicators should not distort incentives. Performance indicators establish the incentive structures within companies, and poor indicators can have unintended consequences. Ownership entities should carefully consider and avoid potential perverse incentives (which are often the result of artificial performance weightings). The goal is to avoid leading managers to aim for targets that do not help the SOE achieve its 
important objectives. Indicators should be realistic and precise and not subject to gaming by management. (Note that almost any indicator may be subject to gaming if the incentives-positive or negative-tied to that indicator are overly strong.) "Soft" targets should be minimized.

- Indicators should be challenging but achievable, based on historical performance. Setting achievable targets helps push a company to higher performance. Benchmarking is crucial; both international and domestic comparators can be used. Assumptions behind the targets should be made explicit, to allow appropriate revision if these assumptions change significantly because of factors beyond the control of company management. Indicators should be robust enough to allow for normal dynamics in the business environment and should provide realistic flexibility.

- Indicators should facilitate benchmarking. Comparing SOEs with companies in the same industry or sector of similar size and subject to similar complexity and risk can help identify performance gaps. Peers can be from the private or the public sector, domestic or foreign. Because SOEs are often monopolies or operate in untraded sectors, many may lack domestic comparators. These could be compared with foreign companies active in the same sector. In addition, ownership entities and SOE managers could consult international benchmarks to identify appropriate targets and see how an SOE measures up against a relevant peer group. ${ }^{3}$ International organizations have prepared standard benchmarks in many sectors (see annex 4A for a set of water sector indicators). Any comparisons of performance should be interpreted with care, however. ${ }^{4}$

- Indicators should be tracked by appropriate information systems. SOEs need to put in place reliable information systems that can track each indicator. To the extent possible, indicator measurements should be equivalent to those obtained directly from company management information systems, with no additional manipulation needed. Once the performance measures have been developed, it should be determined whether the data to support them are available or will need to be collected separately. For example, it may be necessary to survey past clients to find out how well their needs were met by the staff of the organization.

- Indicators should be linked to management performance. The same indicators used to evaluate the company should also be used to evaluate management, and management compensation should be linked, in part, to performance.

- Indicators should be audited. The quality of any indicator depends on its accuracy and reliability. Performance indicators should be audited (by either external or state auditors) to ensure the quality and accuracy of the information provided. 
- Indicators should be simple at the start and enhanced over time. The ownership entity should insist on basic financial and nonfinancial indicators and then push to improve them over time as experience and capacity increase. The ownership entity should regularly review the relevance of performance indicators.

\section{Financial Indicators}

Financial indicators are the traditional measures of company performance. These indicators are based on standard information presented in income and financial statements. Financial indicators commonly used to track financial performance in countries around the world fall into several categories:

- Profitability indicators, including profits, sales, and whether profits are returned to shareholders. The choice of indicators is unique to every industry, sector, and SOE but typically include:

- Revenues, a measure of how much the company has sold during a period, taken directly from the income statement. Revenue growth is a good sign for the company.

- Profits (net income), the measure of profits taken from the income statement.

- Return on equity, net income divided by shareholders' equity. Comparing a company's return on equity with that of other firms in its sector is a good way to measure its competitiveness.

- Return on assets, net income divided by total assets. Return on assets is a measure of the company's effectiveness in using its assets. This ratio is best benchmarked against other companies in the same sector because some sectors can be particularly capital intensive.

- Return on invested capital, net income minus dividends divided by total capital. Return on invested capital is a measure of the company's ability to allocate its capital into profitable investments that produce returns.

- Economic value added, a measure of profit that takes into account the costs of capital (box 4.5).

- Efficiency indicators measure the efficiency of the company and how well it uses the resources at its disposal. These indicators might include the return on assets or equity (described above) along with direct efficiency measures such as the ratio of the costs of production to sales.

- Solvency indicators measure the company's borrowing, its indebtedness, and its ability to service its debt. These indicators include

- Debt-equity ratio

- Liquidity ratio 
BOX 4.5

Measuring Economic Value Added

Many financial analysts have argued that traditional measures of profitability and company success are inadequate. As a result, many ownership entities around the world now evaluate financial performance using the concept of economic value added (or a variant). Developed by the management consulting firm Stern Stewart, this performance measure is intended to capture the true economic profit produced by a company. The basic concept is straightforward: "true" economic profit should account for the cost of capital.

Economic profit is the profit that remains after the costs of a company's capital-both debt and equity-are deducted from operating profit. It can be calculated by taking a company's net after-tax operating profit and subtracting from it the product of the company's invested capital multiplied by its cost of capital. (More formally, economic value added is calculated as net operating profit after taxes, less total invested capital, times the weighted average cost of capital.) A hypothetical example shows the difference between this measure and the older concept of net income. Suppose an SOE earned $€ 100,000$ on a capital base of $€ 1$ million last year. Traditional accounting metrics might suggest that management is doing a good job: the return on capital is 10 percent. But the company's debt obligations and the cost of capital for companies with a similar risk profile add up to an investment cost of capital of 13 percent. Thus, while the company is apparently profitable, it lost 3 percent for its shareholders.

Including the cost of capital in a financial performance indicator is especially important for benchmarking the performance of SOEs because this cost is often invisible to management and owners and consequently is either underestimated or neglected. The challenge for unlisted SOEs is to develop an accurate measure of the cost of capital, a process involving a series of judgments and assumptions. In particular, the weighted average cost of capital is a complex function of the capital structure (proportion of debt and equity on the balance sheet), the stock's volatility measured by its beta, and the market risk premium. Small changes in these inputs can result in big changes in the final calculation of the weighted average cost of capital. In addition, the trademarked version of economic value added has dozens of adjustments to

(box continues on next page) 
BOX 4.5 continued

earnings and balance sheets to calculate net operating profit after tax adjustments-in such areas as research and development, inventory, costing, depreciation, and amortization of goodwill-that must be made before the calculation of standard accounting profit can be used to calculate economic value added.

Despite these technical and practical difficulties, a number of countries are using economic profit or economic value added to assess the performance of SOEs. One of them is China. Another is the United Kingdom, which in 2005 implemented the concept of economic profit measured as after-tax operating profit less the cost of capital charge for the operating assets. Economic profit excludes the gains and losses arising from nonoperating assets, financing flows, and tax effects of the debt-equity capital structure.

Source: Issham et al. 2008; McClure 2009; OECD 2010.

- Asset-liability ratio

- Changes in net borrowing

- Changes in net borrowing from private and public sources

- Investments (equity, loans)

- Nonperforming loans

- Capital adequacy ratio

- Interest covered by earnings

- Budgetary appropriations indicators cover transactions that relate to government transfers to the company, including

- New government investments

- Government credit injections or support

- Subsidies

In a number of countries, it has become common practice to use annual or medium-term performance agreements to set SOE financial targets. As with all performance management instruments, the extent to which these indicators affect actual financial performance depends on the clarity of the financial targets that are set, as the examples below illustrate:

- The New Zealand State-Owned Enterprises Act of 1986 requires SOEs to be "as profitable and efficient as comparable businesses not owned by the government." Included in the three-year statement of corporate intent-which each SOE negotiates with the government-are estimated dividends to be paid and other financial ratios, including rate of return on 
equity, equity-to-assets ratio (the inverse of debt-to-assets ratio), and free funds from operation as a percentage of interest expense (reflecting any risk associated with high debt levels).

- The policy of the Swedish government is to actively manage and monitor the state's assets to achieve the best long-term development in value. The government and each SOE board agree annually on detailed financial targets, based on the performance of internationally successful competitors. For example, the national rail operator was required to match industry standards for returns on equity, interest coverage, and minimum debt-to-equity ratios (Wong 2004).

- The Netherlands benchmarks SOE financial performance against indicators, including return on investment (a minimum return of 3 percent is required), dividend payout (a minimum of 40 percent), and net book value.

- France has developed specific financial indicators for SOEs covering return on assets and equity and debt sustainability (profits in relation to net debt).

Table 4.1 summarizes current government practices in several developing and developed countries for monitoring SOE financial targets.

\section{Nonfinancial Performance Indicators}

Because SOEs are generally required to perform certain noncommercial roles, it is common practice for SOE performance management to go beyond financial indicators to look at specific nonfinancial aspects of the business. These can be tied either to specific programs or to noncommercial objectives established for an SOE, or they can be broader measures that assess social goals consistent with an overall government philosophy. More generally, nonfinancial performance indicators provide a broader perspective on a company's performance. They offer several potential advantages over measurement systems based on financial data alone (Ittner and Larcker 2000):

- They tend to be forward looking. Nonfinancial performance measures tend to act as leading indicators. By contrast, financial indicators are generally lagging indicators of enterprise performance, reporting the historical performance of an enterprise but offering much less value as predictors of future performance.

- They tend to be more closely linked to company strategy. Financial reporting focuses on periodic performance against accounting yardsticks. It does not assess progress toward strategic goals relating to such issues as economic competitiveness or citizen services, including traditionally underserved populations. 
TABLE 4.1 Indicators for Monitoring Different Dimensions of SOE Financial Performance

\begin{tabular}{|c|c|c|c|c|}
\hline Country & What is monitored & $\begin{array}{l}\text { Profitability/ } \\
\text { efficiency }\end{array}$ & Solvency & $\begin{array}{l}\text { Budgetary } \\
\text { appropriations }\end{array}$ \\
\hline Brazil & $\begin{array}{l}\text { - Shareholder } \\
\text { returns }\end{array}$ & $\begin{array}{l}\text { - Return on capital } \\
\text { - Operational margin }\end{array}$ & $\begin{array}{l}\text { - Liquidity } \\
\text { - Assets/liabilities } \\
\text { (including debt) } \\
\text { - Net worth } \\
\text { - Change in net } \\
\text { borrowing }\end{array}$ & $\begin{array}{l}\text { - Deficits/surpluses } \\
\text { (institutional } \\
\text { differences) }\end{array}$ \\
\hline Canada & - & - & $\begin{array}{l}\text { - Changes in net } \\
\text { borrowing from } \\
\text { private/public } \\
\text { - Assets/liabilities }\end{array}$ & $\begin{array}{l}\text { - New government } \\
\text { investments } \\
\text { - Government } \\
\text { credit injections }\end{array}$ \\
\hline India & $\begin{array}{l}\text { - Sales to capital } \\
\text { - Net profit/net } \\
\text { worth } \\
\text { - Return on capital }\end{array}$ & $\begin{array}{l}\text { - } \text { Value added (at } \\
\text { - } \text { Product prices) } \\
\text { cost } \\
\text { - Cost of sales/sales } \\
\text { - Inventory/sales }\end{array}$ & $\begin{array}{l}\text { - Investments (equity/ } \\
\text { loans) } \\
\text { - Net worth } \\
\text { - Debt/equity }\end{array}$ & - \\
\hline Indonesia & - Returns on equity & $\begin{array}{l}\text { - Returns on assets } \\
\text { - Expense/income } \\
\text { ratio } \\
\text { - Net interest } \\
\text { income }\end{array}$ & $\begin{array}{l}\text { - } \text { Nonperforming loans } \\
\text { - Capital adequacy } \\
\text { - Assets/liabilities } \\
\text { - Loans/deposit ratio }\end{array}$ & - \\
\hline New Zealand & $\begin{array}{l}\text { - Dividend yield } \\
\text { - Dividend payout } \\
\text { - Equity return }\end{array}$ & $\begin{array}{l}\text { - Return on capital } \\
\text { - Operating margins } \\
\text { - Efficiency ratios }\end{array}$ & $\begin{array}{l}\text { - } \text { Gearing ratio } \\
\text { - Interests covered by } \\
\text { earnings } \\
\text { - Assets/liabilities }\end{array}$ & - \\
\hline
\end{tabular}

Source: World Bank staff. Note: $-=$ not available.

- They tend to capture intangible success factors. Critics of traditional measures argue that it is the "intangible assets" such as customer loyalty and service, not the balance sheet, that drive success in many industries. Ignoring intangible assets can lead managers to make bad decisions.

- They tend to offer better management incentives. Many aspects of a company's financial performance are outside the control of management. Nonfinancial indicators allow the board to target specific behaviors by management that it wants to encourage.

General nonfinancial performance indicators can cover a broad range of topics, as shown by a list of those most frequently cited in a survey of large U.S. and Canadian companies (table 4.2). 
TABLE 4.2 Nonfinancial Indicators Most Commonly Cited by Large Firms in Canada and the United States

\begin{tabular}{ll}
\hline Customer service & Innovation \\
- Customer satisfaction & - New product development \\
- Delivery performance, customer & - Manufacturing flexibility \\
- service & - Technological capability \\
- Product or process quality & - Research and development productivity \\
- Service quality & - Innovation \\
Market performance & Employee involvement \\
- Marketing effectiveness & - Employee satisfaction \\
- Market growth & - Employee turnover \\
- Market share & - Education, training \\
Goal achievement & - Core competencies \\
- Productivity & - Internal recognition \\
- Environmental compliance & - Morale \\
- Strategic achievement & \\
\hline Source: Stivers et al. 1998. &
\end{tabular}

Many countries are adding corporate governance indicators to their broader performance indicators for SOEs. Indonesia, for example, includes corporate governance as a key performance indicator in its monitoring system, which is based on voluntary assessments and company reviews, with the support of the Ministry of State-Owned Enterprises and government auditors. And in India, compliance with the guidelines for corporate governance is not included as a mandatory parameter in the MOU performance monitoring system, but negative marks will be imposed during performance evaluation for noncompliance of a serious nature.

Nonfinancial performance indicators should generally reflect all important objectives in a company's strategy. The objectives (and thus the indicators) are likely to be specific to the sector in which the company operates. Industry groups and development organizations have identified a range of indicators that measure operational performance in key sectors. One example is the water sector, for which the International Benchmarking Network for Water and Sanitation Utilities has developed indicators covering service coverage, consumption and production, metering practices, efficiency (nonrevenue water), staffing, and quality (see annex 4A).

While there are advantages to having nonfinancial performance indicators, there are potential challenges as well. Ittner and Larcker (2000) identify five limitations: (1) the significant time and cost involved in developing and evaluating a large number of indicators; (2) the lack of a common 
denominator in measuring nonfinancial data, which leads to subjective assessments and makes evaluating performance or trade-offs difficult; (3) the adoption of incorrect nonfinancial measures with no clear bearing on financial performance, which can focus attention on the wrong objectives and make it difficult to link improvements and outcomes; (4) the lack of statistical reliability, which reduces the ability to discriminate superior performance or predict future financial results; and (5) the dilution or "disintegration" of the measurement process when too many measures are chosen. They highlight three steps that can be taken to select and implement appropriate measures: (1) understand and identify the company's value drivers; (2) document, review, and choose measures to ensure consistency and alignment with the company's objectives and strategies, value drivers, and competitive environment; and (3) incorporate the measures as an integral part of reporting and performance evaluation to create employee incentives and influence performance (Ittner and Larcker 2000).

\section{Benchmarking Performance}

An important element of performance monitoring is benchmarking against industry standards and comparators. It allows identifying gaps and areas for improvement. This area is still underdeveloped in many emerging market countries, but ownership entities should strive to benchmark SOE performance against appropriate peers, domestic or foreign.

\section{Balanced-Scorecard Approach for Performance Indicators}

The private sector uses several different performance management framework. Perhaps the best known is the balanced scorecard. ${ }^{5}$ The balanced scorecard is essentially a list of key performance indicators useful for monitoring company performance. Designed as a performance measurement and management framework, it adds strategic nonfinancial performance measures to traditional financial metrics to give managers and executives a more "balanced" view of organizational performance. ${ }^{6}$

The balanced scorecard focuses on measuring three types of objectives in addition to financial performance: customer objectives, internal process objectives, and employee (learning and growth) objectives. These perspectives are used to describe the company's strategy, while a balanced set of performance measures provides the feedback needed to assess performance and adjust and refine the organization's strategy:

- Customer objectives relate to the enterprise's target markets and its ability to meet customer needs. Three traditional ways of measuring "customer 
excellence" are market share and market performance, the ability to acquire new customers, and the ability to retain and satisfy existing customers. The structure of the market (for example, whether the SOE has a monopoly or a strong market position) must be taken into account.

- Internal process objectives relate to internal processes and procedures that lead to profitability and success. These include strategic management, innovation, regulatory compliance, corporate social responsibility, safety, and similar issues. Excellent performance on these internal processes should contribute to achievement of other objectives.

- Learning and growth objectives include productivity, capability, and motivation. Productivity is influenced by capability and motivation. Learning and growth (resulting in capability and motivation) influence process performance, which in turn influences customer performance, which in turn influences financial performance.

Organizations that have been measuring their performance over time tend to be better candidates for the balanced scorecard because they are more experienced in tracking performance within the scorecard framework. In other words, understanding what the different types of measures are, what service aspects they capture, and how they can be used to make decisions helps management frame the measures appropriately. Some companies have been able to use more advanced adaptations as a full strategic planning and management system. The "new" balanced scorecard transforms an organization's strategy from a passive document into daily "marching orders." It helps planners identify what should be done (and measured) and enables executives to truly execute their strategies.

The experience of the Development Bank of South Africa offers one example of the use of a balanced scorecard approach. Its corporate plan, approved annually by the Treasury, includes three components related to the balanced scorecard: development impact, sustainability, and organizational capability. Development impact has substantive weight (56 percent) in the overall performance measurement, which gives a clear signal of the bank's priorities. Key components of this indicator include development fund performance, customer and partner satisfaction, value of total disbursement, cofunding ratio, and share of total commitments to identified market segments. Sustainability indicators account for 24 percent of the total weight and organizational capability for 20 percent (Rudolph 2009). A balanced scorecard approach is also used in the case of Canada's Business Development Bank.

Performance-monitoring systems in many countries have steadily evolved and improved over the years, becoming a key tool for ensuring 
accountability of SOEs and their directors. Such a system provides powerful incentives for companies to improve performance. Commitment from both SOEs and government representatives is vital to achieving good results. In addition, steps can be taken to deal with common challenges that arise during implementation:

- Ensuring that monitoring units have sufficient capabilities. The system places high demands on such units and gives them a central role in the process. In addition to sector-specific technical capacities, individuals serving in these units should also have the requisite financial and management skills.

- Evaluating how social objectives and service delivery targets can be factored into performance agreements. The "nonperformance" elements of the MOU, in particular the social objectives and obligations and government commitments, can have a significant impact on performance but are seen as secondary by the system, making it difficult to hold managers accountable for targets because of external factors. Sector- and enterprise-specific targets should thus find a way to take into account such obligations.

- Revisiting the targeting process. Targets should not be so easy to reach that a great majority of SOEs are rated very good or excellent. Once established, various target areas and objectives need not change on an annual basis, with only specific thresholds being adjusted to reflect the growth of the SOEs and changing market conditions.

- Including compliance with corporate governance standards as a criterion for evaluating and rewarding performance. Compliance with corporate governance codes and guidelines should be factored in and become a criterion for consideration in performance awards.

- Being specific about ministries' obligations. At present, the MOUs appear to provide more specifics on what the company will do than on what the ministries will do. While interministerial decision making may make it difficult to define the specific obligations of the ministries, they will need to be clear so that the ministries' performance can be evaluated.

- Disclosing more on MOUs. MOUs are not easily accessible to the public but contain the basis for company evaluation and hence important information for parliament, other shareholders, and the public. A number of countries have moved to disclose more on their performance management systems. While specific targets do not have to be disclosed, things like social objectives and the target areas for measuring performance can and should be disclosed. 


\section{ANNEX 4A Examples of Key Performance Indicators for the Water Sector}

Area
Service coverage. Coverage is a key development
indicator. All coverage indicators are affected by
whether the data on population and household size
are up to date and accurate. A need to estimate the
population served by public water points or the
number of households per connection may affect
confidence in the water coverage measure.

Consumption and production

Nonrevenue water. Nonrevenue water is water that has been produced and is "lost" before it reaches the customer (through leaks, through theft, or through legal use for which no payment is made). Part of this "lost" water can be retrieved by appropriate technical and managerial actions.

Metering practices. Metering of customers is considered good practice. It allows customers to influence their water bills and provides utilities with tools and information to better manage their systems.

Network performance. The number of pipe breaks, relative to the scale of the system, is a measure of the ability of the pipe network to provide a service to customers. The rate of pipe breaks can also be seen as a surrogate for the general state of the network, although it also reflects operation and maintenance practices.

Cost and staffing. Unit operational costs provide a "bottom line" assessment of the mix of resources used to achieve the outputs required. The preferred denominator for operational costs is the amount of water sold. This ratio then reflects the cost of providing water at the customer off-take point. Lack of universal metering, lack of accurate household meters, and a focus in the past on water production mean that an alternative measure of operational costs per cubic meter of water produced is also relevant in the short term.

\section{Indicators}

Water coverage. Population with access to water services (with a direct service connection or within reach of a public water point) as \% of total population under utility's nominal responsibility.

Water production. Cubic meters $\left(\mathrm{m}^{3}\right)$ per connection per month.

Total water consumption. Liters per person per day or $\mathrm{m}^{3}$ per connection per month.

Nonrevenue water. Difference between water supplied and water sold (volume of water "lost") as \% of net water supplied.

Nonrevenue water. Volume of water "lost" per km of water distribution network per day $\left(\mathrm{m}^{3} / \mathrm{km} /\right.$ day).

Metering level. Number of connections with operating meter as \% of total number of connections.

Water sold that is metered. Volume of water sold that is metered as \% of total volume of water sold.

Pipe breaks. Total number of pipe breaks per year per $\mathrm{km}$ of water distribution network.

Unit operational costs. Annual water service operational expenses/total annual volume sold (US $\$ / \mathrm{m}^{3}$ sold).

Staff costs. Number of staff per thousand water connections.

Staff costs. Number of staff per thousand people served.

Labor costs relative to operational costs. Total annual labor costs (including benefits) as \% of total annual operational costs.

Electrical energy costs as \% of operational costs.

Contracted-out service costs as $\%$ of operational costs.

(table continues on next page) 


Area
Quality. The measures presented are a limited first
step in capturing information on quality of service.
Complaints, while relatively easy to track, give only a
glimpse of actual company performance; consumers
may have become accustomed to poor service and
not complain. In other cases, it may be difficult for
customers to report complaints. Capturing at least
some customer-derived data, however, is
considered to be an important starting point.

Financial indicators. Billing customers and getting paid are two different things. The effectiveness of the collections process is measured by the outstanding revenue at year-end compared with the total billed revenue for the year, in day equivalents, and by the total amount collected as a percentage of the billed amount.

Assets. The capital intensity of the utility is indicated by the gross fixed-asset value per capita served.

\section{Indicators}

Continuity of service. Average hours of service per day for water supply.

Quality of water supplied. Number of tests for residual chlorine.

Quality of water supplied. Samples passing on residual chlorine (\%).

Complaints. Total number of complaints per year as \% of total number of water and wastewater connections.

Total annual operating revenue per volume of water sold (US $\$ / \mathrm{m}^{3}$ water sold) or per connection.

Collection period. Year-end accounts receivable/total annual operating revenues.

Collection ratio. Cash income as \% of billed revenue.

Gross fixed assets. Total gross fixed assets per population served (US\$/population served).

Source: Adapted from the International Benchmarking Network for Water and Sanitation Utilities indicators. Full data set and descriptions are available at http://www.ib-net.org.

Note: $\mathrm{km}=$ kilometer

\section{Notes}

1. Two key references for setting up performance monitoring frameworks for SOEs are OECD (2010) and Johnson and Beiman (2007).

2. Large companies may benefit from hiring an outside consulting firm to assist in defining their strategy.

3. General sources of benchmarking information include (1) OneSource, a division of infoUSA, which integrates content of different types from 31 information providers and provides summary information on dozens of industries;

(2) Thomson Reuters Global Fundamentals, which provides coverage of more than 25,000 global companies in developed and emerging world markets; and (3) Dunn \& Bradstreet's database, which provides key information on public and private companies and their subsidiaries.

4. International benchmarks should be used in moderation and with caution. Countries have different accounting rules and systems, and these differences can have significant effects on a company's financial results. (This underscores the importance of nonfinancial measures, which are not affected by differences in accounting rules and systems.) Countries also have different tax policies, cost structures, and workforce compensation rates and rules.

5. The balanced scorecard was originated by Robert Kaplan (Harvard Business School) and David Norton. Other performance management systems in use today include activity-based costing and management, economic value added, 
quality management, customer value analysis or customer relationship management, and performance prism.

6. In the balanced scorecard framework, key performance indicators are referred to as "measures."

\section{References}

CCMAU (Crown Company Monitoring Advisory Unit). 2007. Owner's Expectations Manual for State-Owned Enterprises. Wellington: CCMAU.

de Luna-Martinez, Jose, and Carlos Fernando Vicente. 2012. "Global Survey of Development Banks.” Policy Research Working Paper 5969, World Bank, Washington, DC.

DPE (Department of Public Enterprises, Ministry of Heavy Industries and Public Enterprises, India). 2010-11. Public Enterprises Survey 2010-2011 Overview: Annual Report on the Performance of Central Public Sector Enterprises. New Delhi: DPE.

—. 2013. Annual Report on Public Enterprises, 2012-2013. New Delhi: DPE.

Issham, Ismail, Abdul Samad M Fazilah, Yen Siew Hwa, Anton Abdulbasah Kamil, Azli Azli Ayubh, and Meor Azli Ayubh. 2008. "Economic Value Added (EVA) as a Performance Measurement for GLCs vs Non-GLCs: Evidence from Bursa Malaysia." Prague Economic Papers 3. http://www.vse.cz/pep/abstrakt .php3?IDcl=328.

Ittner, Christopher, and David Larcker. 2000. "Non-financial Performance Measures: What Works and What Doesn't." Financial Times, Mastering Management Series, October 16. Reissued by Knowledge@Wharton. http:// knowledge.wharton.upenn.edu/article.cfm?articleid=279.

Johnson, Christian C., and Irv Beiman, eds. 2007. Balanced Scorecard for StateOwned Enterprises: Driving Performance and Corporate Governance. Manila: Asian Development Bank.

McClure, Ben. 2009. "All About EVA.” http://www.investopedia.com/articles /fundamental/03/031203.asp\#axzzlz79rlFMx.

Muir, Russell, and Joseph Saba. 1995. "Improving State Enterprise Performance: The Role of Internal and External Incentives." Technical Paper 306, World Bank, Washington, DC.

OECD. (Organisation for Economic Co-operation and Development). 2010. Accountability and Transparency: A Guide for State Ownership. Paris: OECD.

Robinett, David. 2006. "Held by the Visible Hand: The Challenge of SOE Corporate Governance for Emerging Markets.” World Bank, Washington D.C.

Rudolph, Heinz P. 2009. "State Financial Institutions.” Public Policy for the Private Sector, Crisis Response Series, Note 12, World Bank, Washington, DC.

Shirley, Mary. 1998. "Why Performance Contracts for SOEs Haven’t Worked.” Public Policy for the Private Sector, Note 150, World Bank, Washington, DC. http://siteresources.worldbank.org/EXTFINANCIALSECTOR/Resources /282884-1303327122200/150shirl.pdf. 
Stivers, B. P., T. J. Covin, N. G. Hall, and S. W. Smalt. 1998. "How Nonfinancial Performance Measures Are Used.” Management Accounting (February) 44: 46-49.

Wong, Simon C. Y. 2004. "Improving Corporate Governance in SOEs: An Integrated Approach." Corporate Governance International 7 (2): 5-12.

World Bank. 2010. "Corporate Governance of Central Public Sector Enterprises: Republic of India.” Finance and Private Sector Development Vice Presidency, World Bank, Washington D.C. 


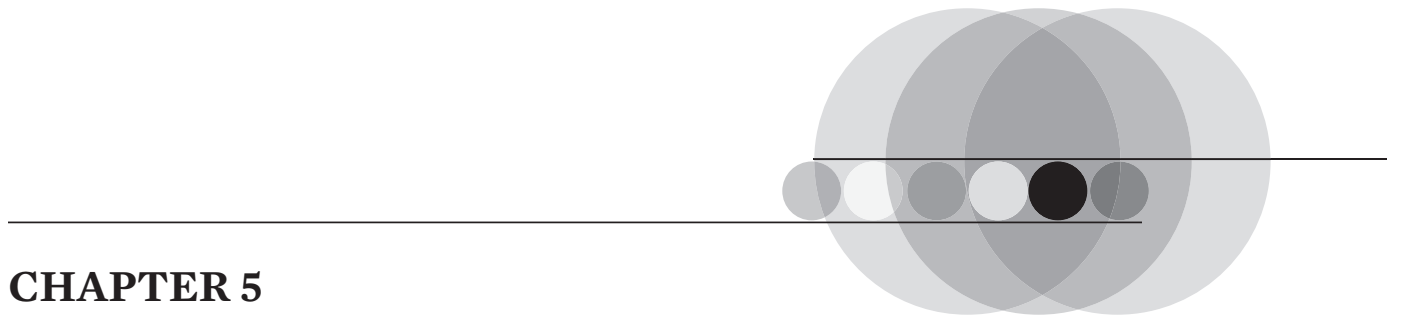

\section{Financial and Fiscal Discipline}

Applying financial and fiscal discipline to state-owned enterprises (SOEs) can reduce government liabilities and simultaneously strengthen incentives for improved SOE governance and performance. Reducing preferential access to direct and indirect public financing increases the commercial orientation of SOEs and helps level the playing field with the private sector. Meanwhile, computing the true cost of public service obligations (PSOs) and assessing those SOE activities with an explicit budget transfer, as well as monitoring SOE liabilities, enable a meaningful assessment of the operational efficiency of these enterprises. For genuine financial and fiscal discipline, governments must neither provide a financial advantage nor impose a financial disadvantage on SOEs relative to the private sector.

This chapter highlights the steps involved in achieving financial and fiscal discipline by

- Reducing SOE preferential access to financing (where it exists)

- Identifying and separating out the cost and funding of public service obligations

- Monitoring and managing the fiscal burden and potential fiscal risk of SOEs. 


\section{Key Concepts and Definitions}

Principles of competitive neutrality or a level playing field (see chapter 2) provide governments a framework for strengthening the financial and fiscal discipline of SOEs, for reducing SOEs' preferential access to finance, and for managing the fiscal burden and potential fiscal risks associated with SOEs. Government policies that confer special advantages or benefits on SOEs in the form of direct and indirect support or that do not impose the discipline of capital markets can result in risk that is out of proportion to a company's financial returns. In addition, SOEs may accumulate contingent liabilities through political interference, operational inefficiencies, or poor decision making that remain uncorrected by market forces. A range of fiscal risks can arise that can affect the fiscal position of government.

In many jurisdictions, one of the key rationales for continued ownership of SOEs is that they tend to provide goods or services that would not be provided by the private sector or, if they were, would be provided on different commercial terms. The delivery of these public service obligations remains a compelling reason for some governments to maintain and support SOEs. Nonetheless, the reliance on SOEs to perform public service obligations can create fiscal risks for the government, as PSOs may impose funding requirements that fall outside the usual budget processes. In addition, as governments are the residual risk holder of SOEs, changes in the values of equities held in SOEs could also create fiscal risks.

A credible hard budget constraint hinges on the notion that, in the face of poor financial performance by an SOE, the government might refuse to provide additional financing and let the SOE fail. However, if an SOE is fundamental to the delivery of essential government services, the threat of hard budgets may be compromised and thus weakened or nonexistent. For listed companies, poor performance can be addressed through capital market discipline-that is, poor performance will lead to asset price and ownership changes, which will lead to changes in management. But for SOEs, particularly those with noncommercial obligations, the threat of management change may be less strong.

\section{Reducing Preferential Access to Financing}

SOEs often benefit from different types of direct or indirect financial or fiscal support that are unavailable to privately owned firms. These privileges may undermine financial discipline and lead to market distortions, generating inefficiencies for SOEs as well as other public entities such as 
state-owned banks. In reaction to these negative consequences, many countries have adopted policies to bring greater financial discipline to SOEs and level the playing field with the private sector. The following is a description of common forms of preferential financial or fiscal support enjoyed by SOEs.

\section{Common Forms of Financial Support}

Direct Financial Support. Direct financial assistance through budget provisions or subsidies is the most obvious form of government support. Although such support is usually justified on the grounds that SOEs fulfill special public functions or provide noncommercial services, direct funding can create market distortions, particularly when funds are used to crosssubsidize commercial services or products. Budget funding may also exceed company needs, in which case SOEs may pursue business strategies that affect the market structure in which they operate, strategies they would not have pursued otherwise. For example, easy access to financing may allow very rapid SOE growth, enabling these enterprises to secure a dominant position over their competitors or to adopt aggressive acquisition strategies that may lead to excessive market concentration. ${ }^{1}$ For these reasons, many countries have chosen to reduce direct support to SOEs, especially to those that operate in competitive markets.

Indirect Financial Support. By virtue of state ownership, SOEs can also obtain significant financial benefits through more subtle, indirect routes. These privileges include preferential access to finance, debt financing, equity financing, and tax treatment and less rigorous financial accounting standards.

SOEs often have preferred access to financing, such as loans at belowmarket interest rates provided directly from the government or through directed lending from state-owned banks (which are frequently the most significant SOE creditors). Often, the relations between SOEs and stateowned banks are not purely commercial, which can lead to government interference in lending decisions and potential conflicts of interest. Furthermore, access to cheaper credit may distort the SOEs' incentive structure and shelter managers from market pressure.

SOEs may also receive preferential treatment in private financial markets if the government explicitly guarantees SOE debts or if private creditors assume an implicit state guarantee against default. Whether from public or from private sources, preferential access to finance may result in excessive indebtedness and generate severe inefficiencies in the SOE, as well as 
creating a disadvantage for competitors. This situation may ultimately prove costly to taxpayers.

Direct liabilities may arise when the government borrows funds to lend to an SOE. These funds constitute a direct liability for the SOE (which must repay the state) as well as for the state (which must repay the lender). Whether or not this form of debt financing generates a drain on the budget depends on the financial position of the SOE-that is, whether its profitability and financial position allow it to repay the loan to the government and the terms of that repayment.

Although it is preferable for SOEs to raise their own debt from financial markets, thus becoming exposed to market discipline, the state may still guarantee SOE borrowings (so that if the SOE defaults, the state must pay). Contingent liabilities such as this are an important source of fiscal risk. Additional fiscal risks may arise through other guarantees, such as publicprivate partnerships with SOEs in which the government guarantees a minimum economic return to the private partners. Contingent liabilities are often unspecified and fail to appear in the budget where they could be subject to greater public scrutiny.

Equity financing is commonly used by privately owned firms. However, SOEs often have rigid capital structures that cannot be easily modified, increased, or transferred. This rigidity may shelter SOE managers from competitive pressure and protect SOEs from takeover risks resulting from inefficient performance. Without the fear of a falling stock price, SOE directors may follow a below-market dividend policy or a below-cost pricing policy.

SOEs may enjoy lower corporate tax rates or exemptions from indirect taxes such as the value-added tax (VAT). Exemptions such as these are more common for nonincorporated SOEs than for corporatized SOEs or statutory corporations, which generally face tax requirements similar to those of the private sector. Even when SOEs are subject to the same tax rates as the private sector, they are sometimes allowed to defer tax payments to the government. Deferral of dividend payments is another form of indirect financial advantage.

If the financial accounting standards that SOEs must adhere to are less rigorous than the standards for private sector firms, then SOEs may enjoy a tangible advantage. This is especially true if the SOE accounting standards affect their perceived basic cost structure. For instance, an SOE may have an advantage over its private sector competitors when its reporting of debt and equity positions allows assets to be undervalued or if some production costs are not considered in the pricing of products and services. In practice, it is difficult to determine whether this situation occurs. However, competitive 
neutrality concerns arise whenever the products and services provided by an SOE are underpriced (OECD 2011c).

\section{Financial and Fiscal Policies to Reduce Preferential Financing}

It is now considered good practice to design financial and fiscal policies for SOEs that promote operational efficiency, create value for the state as owner and shareholder, and preserve the revenue stream attached to SOE ownership, while managing the state's fiscal risk from SOE operations. Per the OECD's Guidelines on Corporate Governance of State-Owned Enterprises, the broad principles and policies for achieving these goals touch on transparency in budgetary support, commercial relations with state-owned banks, flexibility in capital structure, and tax neutrality.

Funding from the budget should be transparent, clearly separating commercial from noncommercial activities and associating budget support with outputs and outcomes, such as citizens served, efficiency gains, service quality, innovation, social progress, or economic impact. It is good practice to limit budget support to the costs associated with explicit public service obligations.

The credit terms offered by state-owned banks to SOEs and other government businesses should be in line with the credit terms offered to private companies, particularly if the SOE offers a product or service in competition with the private sector. SOEs and state-owned banks should observe strict limits on cross-board membership to help base their relationship on purely commercial grounds.

The state as an enterprise owner should develop mechanisms that allow appropriate changes in SOEs' capital structure, with approval by the legislature as needed. This ex ante flexibility should be tied to ex post accountability through audits devised to uncover any form of cross-subsidization through capital transfers between commercial and noncommercial activities.

SOEs and private companies should be subject to the same tax regime. As reported by the Organisation for Economic Co-operation and Development (OECD 2011b), the implementation of this principle generally varies according to whether government businesses are incorporated or directed by a government department (box 5.1). Typically, SOEs with the legal status of a stock company or statutory corporation face direct and indirect tax requirements similar to those of private enterprises. Conversely, it can be legally difficult to impose corporate taxation on the earnings of enterprises directed by government departments, and the activities of these SOEs are often not subject to indirect taxes either. To level the playing field between providers, compensatory payments equivalent to tax liabilities may be imposed on SOEs. 
BOX 5.1

\section{Taxing Finnish and Norwegian SOEs}

In Finland, the income tax on SOEs (around 6.2 percent in 2007) is roughly 20 percentage points lower than the income tax on private firms engaging in similar operations (26 percent). Moreover, if a state statutory corporation produces services primarily for state administration, it is exempt from income tax. The activities of municipal statutory corporations are taxed even more leniently. In its Finnish Road Enterprise Decision in 2006, the European Commission judged that the benefits pertaining to taxation and bankruptcy protection could be considered prohibited state aid. As a result of that decision, Finland began to reexamine its state enterprise model.

In Norway, neither public nor private entities have to pay VAT on production for their own use. To save money, municipalities have resorted to more in-house production; thus, the VAT regime penalizes the operation of potentially more efficient private providers. In 2003, a compensation scheme that neutralizes VAT on public purchases was introduced, which served to reduce, but not eliminate, such distortions.

Source: OECD 2011b.

\section{Identifying and Separating Out Public Service Obligations}

Throughout the world, governments have created SOEs as commercial entities and then imposed noncommercial public service obligations on their operations. Also referred to as quasi-fiscal activities, community service obligations, or public service agreements (PSAs), public service obligations enable governments to pursue public policy through SOEs rather than through regular budget channels, often with little transparency.

Common examples of PSOs include providing services to underserved communities or offering services at a price below cost. For example, in Nigeria, SOEs must sell energy at an average of US\$.06 per kilowatt hour below cost (Rice 2012). China's government mandates that the state-owned oil and gas producer Sinopec sell oil below market prices; the profits of this SOE are thus well below their full potential (Raham 2012). 
PSOs may reflect entirely legitimate policy objectives. However, it is important to be aware of the many challenges. Generally, these challenges are greater if PSOs are not explicit and are included as part and parcel of the SOEs' overall commercial activities:

- Costing and funding of PSOs may be borne by the SOE rather than paid by the government through normal budget approval processes.

- Decisions about the funding of PSOs are often made through less-rigorous processes and are often seen as implicit subsidies that reduce SOE efficiency and impose significant fiscal burdens on government. In Indonesia, for example, payments from the state budget to finance noncommercial SOE objectives averaged 4 percent of gross domestic product (GDP) during 2003-06, which was greater than the entire government budget spending on education and health (Verhoeven et al. 2008).

- PSOs may result in overall losses for the SOE or may need to be crosssubsidized by other SOE operations, leaving some recipients of a government service to pay more so that others may pay less.

- When SOEs have public service obligations that are inconsistent with their financial objectives, it can be exceedingly difficult to monitor and assess the SOE's commercial performance.

- Budget transfers may crowd out more effective public spending for disadvantaged groups. For instance, in Bangladesh at least US\$5.5 billion (or 7 percent of GDP) was channeled to SOEs through the budget in $2008 .^{2}$ Considering Bangladesh's limited revenue-mobilization capacity and the lack of transparency and evaluation of PSOs, these payments were not likely the most effective use of scarce government resources (Kojo 2010).

The OECD's Guidelines on Corporate Governance of State-Owned Enterprises recognize that SOEs are frequently "expected to fulfill special responsibilities and obligations for social and public policy purposes ... [that] may go beyond the generally accepted norm for commercial activities" (OECD 2005, 20). In addition to formalizing these PSO mandates in legislation or regulations disclosed to the public at large, the OECD guidelines suggest three steps for implementing PSOs without compromising SOE efficiency relative to other market players:

- Define and calculate the costs of PSOs.

- Finance these costs through a specified budget transfer to the SOE so that the cost is explicit both in the budget and in the SOE's financial statements.

- Monitor the performance of PSOs to enhance transparency and ensure their relevance and effectiveness. 


\section{Defining Public Service Obligations and Their Costs}

A PSO must be defined clearly and separated from the regular commercial activities of the SOE. While the OECD guidelines provide a broad definition, PSOs are usually defined more specifically at the country level. For example, in Australia, a community service obligation arises when a government specifically requires a public enterprise to carry out activities relating to outputs or inputs that the enterprise would not elect to do on a commercial basis and which the government does not require other businesses in the public or private sector to undertake, or which the enterprise would do commercially only at higher prices (AIC 1994). In addition to pricing and service delivery requirements, PSOs may oblige SOEs to use specific inputs with constraints or conditions that do not apply to private firms (OECD 2010).

Calculating the cost of a mandated PSO can be a complex exercise, as these obligations involve offering public goods for which the price, by definition, is difficult to determine. Nonetheless, estimating costs is an important process, for it allows governments to assess whether the services being provided are worth the cost. In New Zealand, after the SOE Act was passed, NZ Post was funded by the state to provide post offices in rural areas. However, once the cost of these services was transparent, the government decided that there was a better way. Funding was reduced and rural post offices closed, but convenience stores and other outlets began to sell stamps and provide other basic postal services more efficiently than the dedicated post offices.

SOEs typically have an incentive to overestimate the true costs of PSOs. If information asymmetries between SOE and government are significant, the SOE may be overpaid for fulfilling those obligations. However, government tends to underestimate the cost of PSOs. Various methods of calculating PSO costs are discussed in the OECD's Accountability and Transparency Guide for State Ownership (OECD 2010). Following are the four main methods and their associated pros and cons:

- Marginal costs. While reflecting the real opportunity cost of supplying the service, the estimation of marginal costs can be daunting due to practical difficulties such as treatment of common and joint costs, depreciation, and variations in demand.

- Fully distributed costs (or average variable cost plus a markup to cover fixed costs). These calculations tend to overestimate costs.

- Avoidable costs (or costs associated with an additional block of output, including variable and capital costs whenever additional capacity is required). This is a commonly used method. 
- Stand-alone costs (or costs for producing an output in isolation). This method ignores economies of scale and scope and usually results in significant overestimation of the real cost.

In some settings, SOEs are required to maintain separate accounts for commercial and noncommercial activities (see the example of Italy in box 5.2). The European Commission uses a tool known as the "transparency directive" to achieve competitive neutrality between public and private firms, ${ }^{3}$ which requires public companies to have separate accounts for commercial and noncommercial activities to demonstrate how their budget is divided. This tool has been used in many sectors, including postal services, energy, and transport. ${ }^{4}$

A more radical approach requires the structural separation of the business and nonbusiness parts of an SOE, which is the easiest way to prevent crosssubsidization. However, efficiency gains may be lost if economies of scale

\section{BOX 5.2}

\section{Italian Public Service Agreements}

Special obligations for SOEs that provide services of general interest are usually set forth in the public service agreement (contratto di programma) signed by the company and the relevant ministry, in accordance with the Ministry of Economy, for a period of at least three years.

The agreement aims to ensure that end-users have safe, reliable services at reasonable prices and that market competition is always maintained. An agreement must also define the standards applicable to the characteristics and quality of services, the level of tariffs (typically using the price-cap method), the productivity targets, and the production costs per unit.

In general, the PSAs have improved the efficiency of public services. The agreements define the services that each SOE must provide (but whose costs are not covered by tariffs) and the related compensation by the state. SOEs that receive state funds to provide public services are required to keep separate accounts to show the distinction between these and all other SOE activities, their associated costs and revenues, and the methods used to allocate costs and revenues. This system, in accordance with European Union (EU) laws, is required to avoid crosssubsidies that harm competition in the relevant sector.

Source: OECD 2010, box 12. 
cannot be realized through a joint provision of commercial and noncommercial activities. Similarly, separation of activities may be unadvisable if the provision of commercial (or noncommercial) activities is very limited compared to the rest of the SOE's activities. Or separation may simply be impossible if commercial and noncommercial activities require the same capital equipment or qualified human resources. In certain sectors, commercial activities are carried out by unincorporated entities that share assets with some units of government. If the costs of such assets are fixed, separation will not be straightforward; therefore, developing an appropriate cost-allocation formula will be essential to ensuring competitive neutrality (OECD 2011b). Given the complexities involved in PSO costing, methodologies may have to be adopted on a case-by-case basis, taking into account the specific circumstances of individual industries, companies, and institutional capacities.

A basic principle holds that governments should not mandate PSOs whose cost exceeds their value to the public. Yet, it is more difficult to determine whether a PSO could be replaced by another mechanism that could achieve the same objectives at a lower cost, more effectively, or with fewer market distortions. Potential alternative mechanisms include direct subsidies or (conditional) cash transfers to targeted populations, vouchers, contracting out services to private providers (where they exist), and regulatory provisions. $^{5}$

\section{Financing PSOs Directly from the Budget}

In line with good practice, once PSOs are defined and costed, they can be funded directly from the budget, and the size of the government transfer can be divulged (IMF 2007). The government can then purchase PSO services from SOEs under arm's-length commercial contracts and signal to non-SOE suppliers the price against which to compete as a future provider of those services. Where PSOs are met through restrictions on competition or other regulatory distortions, a similar costing and value-for-money exercise should be conducted. The economic costs of preferential regulatory treatment should be assessed against the value of the objectives achieved. Alternative ways to achieve the same benefits at lower cost should be considered (OECD 2007). ${ }^{6}$

While the transparent funding of noncommercial SOE activities through the budget is good practice, alternative solutions-such as vouchers-may be more readily applied in institutionally weak settings. Vouchers are like coupons that the government provides to households to use to pay for a service. The consumer gives the coupon to the service provider, and the service provider can then exchange the voucher for cash from the government. 
For example, rather than paying SOEs to provide low-cost electricity to certain groups of consumers, the government may wish to give electricity vouchers to low-income residents. In this way, the government ensures that the benefit goes to the intended recipient and does not undermine commercial discipline through direct transfers from the budget. In addition, where markets are competitive, consumers can seek the most efficient provider and use the voucher for that provider.

Even with complete transparency, SOEs that operate inefficiently can impose a substantial financial burden on the government. For example, many railways operate loss-making passenger services that can be financially significant. In Serbia, the government took over the rail system in 2005 and has been providing explicit subsidy payments ever since. However, even with a well-structured subsidy, those payments account for 72 percent of the rail system's operating revenues. In 2008 and 2009, the operating subsidies were 0.41 percent and 0.43 percent of Serbian GDP, respectively (World Bank 2011).?

\section{Monitoring and Disclosing PSOs}

Monitoring and evaluation of PSOs is critical to ensuring their relevance and effectiveness. Monitoring is usually conducted through the overall performance-monitoring system for SOEs (see chapter 4). A specific review could also be carried out separately with the involvement of concerned departments and stakeholders. Progress in meeting PSOs-and their attendant costs-should be disclosed to the general public to enhance transparency.

\section{Managing the Fiscal Burden and Fiscal Risk of SOEs}

If an SOE does not perform well, the government faces a financial risk. Implicit payments to SOEs may lead to a systematic underestimation of the risk. The government's goal in managing SOE-associated fiscal risks should be to determine the actual amount of risk, manage that risk though appropriate debt management rules, and encourage better SOE performance. Tactics and tools for accomplishing these aims are discussed below.

\section{Consolidating Complete Information}

Comprehensive information on SOEs as a group-as well as on individual SOEs-is needed. Not all governments have a complete picture of all 
enterprises in their SOE portfolio, particularly when SOEs are parent companies with subsidiaries. In that case, a thorough mapping of SOEs is a crucial first step. Once the SOE portfolio list is complete, relevant financial and nonfinancial information must be gathered for each enterprise. For this purpose, the importance of audited financial statements cannot be overstated; they should be independently prepared and audited in accordance with accepted professional accounting and auditing standards. Still, because financial statements alone do not provide full information on financial position and risks, narrative information should be supplied to provide context.

In the private sector, it is now good international practice for companies to prepare an annual management commentary, a narrative report that provides context and explanation to the annual financial statements and focuses on forward-looking information. A few OECD countries have adopted this practice for SOEs. ${ }^{8}$ In Sweden, for example, SOEs are required to issue detailed quarterly reports, including financial statements and a management discussion on operations and risks. In addition, some Swedish SOEs have organized "capital market days," when external financial analysts and financial journalists can probe further.

In some countries, particularly in Latin America and the Caribbean, fiscal statistics include SOEs (see box 5.3). In such cases, consistent financial information on SOEs enables the government to set fiscal targets for deficits and debt for the public sector as a whole, which ensures that the fiscal burden of SOE operations is reflected in budget decision making. This approach may have downsides for SOEs, however. For example, when the government target for fiscal policy is defined in terms of the financing requirement of the public sector, SOEs may find it difficult to make the case for the investments needed to meet business goals. Such capital expenditures would need to be traded off within the fiscal target against all other public sector spending, including for critical government priorities such as health and education, which complicates decision making and creates obstacles for SOE investment. Furthermore, fiscal statistics do not clearly identify SOE contingent liabilities and other factors that could affect the fiscal burden associated with SOEs over the longer term. Thus, even in cases where fiscal statistics and policy goals cover SOEs, supplemental information on the longer-term outlook for SOEs is needed for maintaining fiscal discipline.

\section{Assessing Fiscal Risks of SOEs}

Estimation of fiscal risks associated with PSOs and SOE contingent liabilities is challenging. It is therefore sensible to focus on those SOEs that pose large 
BOX 5.3

\section{Managing the Impact of SOEs on Fiscal Discipline: An Investigation of the International Monetary Fund}

In a series of papers in 2004-05, the International Monetary Fund (IMF) addressed the question of how fiscal policy should be managed in relation to SOEs (IMF 2004, 2005). A few observations underpinned this investigation:

- Fiscal statistics form the basis for fiscal policy. In cases where fiscal statistics cover SOEs, their activities can be (and often are) incorporated into setting targets for fiscal discipline, such as deficit and debt goals. But when SOE information is missing from fiscal statistics, the perspective on the cost of PSOs and contingent liabilities is often much more limited.

- The coverage of SOEs in fiscal statistics reported by countries and used by the IMF and others for assessing fiscal discipline varies greatly. In 2004, the IMF's reporting on fiscal statistics included SOEs for over 80 percent of Latin American countries, against at most 14 percent in other non-OECD countries and 5 percent in OECD countries (IMF 2004). ${ }^{\mathrm{a}}$

- Whether fiscal discipline considerations warrant including SOEs directly in targets for fiscal policy depends on their commercial nature. SOEs that are charged with significant PSOs and rely substantially on government support or guarantees (including implicit guarantees) would not be considered commercial enterprises. Because of their potentially significant impact on fiscal discipline in the short run or over time, including operations of these SOEs in the government's fiscal targets is important for better fiscal discipline. Commercially run SOEs, however, may be excluded from fiscal targets, so that operational decisions, such as those on investment, can be based solely on business considerations. However, when a consolidated balance sheet of public sector operations is used as is consistent with preferred practice for government financial statistics, then such SOEs will be included in the estimation of the financial footprint of government.

An assessment of SOEs in six pilot countries (Brazil, Colombia, Ethiopia, Ghana, Jordan, and Peru) found that only 3 out of 115 assessed firms met the conditions for being commercially run (IMF 2005).

(box continues on next page) 
BOX 5.3 continued

With so few SOEs meeting the standard for commercial firms, the IMF proposed a more flexible approach aimed at including in fiscal targets only those SOEs that pose "sufficiently large" fiscal risks. To assess such risks, the IMF developed criteria based on the standards for identifying commercially run enterprises but revised them based on experiences with the pilot SOE assessments (see table 5.1). While the criteria for determining whether SOEs are commercially run were mechanical and binary, the proposed assessment of fiscal risk was based on judgment and included a scale ranging from low to high. According to the IMF investigation, accounting for SOEs in fiscal policy is not straightforward and needs to be approached on a case-by-case basis. Where public sector accounts are comprehensive, setting fiscal targets for the entire public sector including SOEs (in any event, those that pose significant fiscal risk) makes sense. This exercise ensures that efforts to maintain or strengthen fiscal discipline are not undermined by shifting activities off the budget and onto SOEs and thereby worsening SOEs' financial condition. At the same time, many countries are not ready to cover the public sector comprehensively in their fiscal accounts, as they are still in the process of implementing the standards contained in the 2001 Government Finance Statistics Manual (IMF 2001). In those cases, ensuring that PSOs are funded through the government budget and that fiscal risks are effectively monitored and disclosed is critical.

a. The 2001 Government Finance Statistics Manual (IMF 2001) advises countries to produce statistics on SOES and the overall public sector.

fiscal risks. IMF (2005) outlines a set of criteria for identifying SOEs that expose the government to large risks. These criteria focus on the government's involvement with the company, its financial and operational track record, the quality of the SOE governance, and its strategic importance to the government (see table 5.1). These criteria cannot be applied in a mechanical manner and require significant information on the SOEs beyond what is readily available. ${ }^{9}$ Implementation and identification of SOEs that pose large fiscal risks therefore need to be part of an in-depth assessment of fiscal risks related to these enterprises.

Scrutinizing SOEs that expose the government to substantial fiscal risks is common sense. In particular, establishing the SOEs' baseline financial conditions and the financial relationship with the government budget is important, as well as predicting how that budget relationship would be affected by 
TABLE 5.1 Criteria for Assessing Fiscal Risks of SOEs

\begin{tabular}{|c|c|}
\hline Category & Nature \\
\hline \multirow[t]{2}{*}{$\begin{array}{l}\text { Managerial } \\
\text { independence }\end{array}$} & $\begin{array}{l}\text { Pricing policies. Are prices of the SOE in line with international benchmarks (for traded } \\
\text { goods and services); set at cost coverage (nontraded goods); is the tariff-setting regime } \\
\text { compatible for long-term viability of the SOE and compatible with private firms (regulated } \\
\text { services)? }\end{array}$ \\
\hline & $\begin{array}{l}\text { Employment policies. Is this independent of civil service law? Does the government } \\
\text { intervene in wage setting and hiring? }\end{array}$ \\
\hline \multirow[t]{3}{*}{$\begin{array}{l}\text { Relations with } \\
\text { government }\end{array}$} & $\begin{array}{l}\text { Subsidies and transfers. Does the government provide direct or indirect subsidies or } \\
\text { explicit and implicit loan guarantees to the SOE not provided to private firms? Does the } \\
\text { SOE provide special transfers to government? }\end{array}$ \\
\hline & $\begin{array}{l}\text { Quasi-fiscal activities. Does the SOE perform uncompensated functions or incur cost not } \\
\text { directly related to its business objective? }\end{array}$ \\
\hline & $\begin{array}{l}\text { Regulatory and tax regime. Is the tax and regulatory regime in the industry the same for } \\
\text { the SOE as for private firms? When appropriate, is the fiscal relationship with the SOE } \\
\text { being managed by the large taxpayer unit? }\end{array}$ \\
\hline \multirow[t]{3}{*}{$\begin{array}{l}\text { Governance } \\
\text { structure }\end{array}$} & $\begin{array}{l}\text { Periodic outside audits. Are these carried out by a reputable private firm according to } \\
\text { international standards and published? }\end{array}$ \\
\hline & $\begin{array}{l}\text { Publication of comprehensive performance reports. Are these published on an annual } \\
\text { basis? }\end{array}$ \\
\hline & Shareholders' rights. Are minority shareholders' rights effectively protected? \\
\hline \multirow{3}{*}{$\begin{array}{l}\text { Financial } \\
\text { conditions and } \\
\text { sustainability }\end{array}$} & $\begin{array}{l}\text { Market access. Can the SOE borrow without government guarantee and at rates } \\
\text { comparable to private firms? }\end{array}$ \\
\hline & $\begin{array}{l}\text { Less-than-full leveraging. Is the SOE's debt-to-asset ratio comparable to that of private } \\
\text { firms in the industry? }\end{array}$ \\
\hline & $\begin{array}{l}\text { Profitability. Are the SOE's profits comparable to those of private firms in the industry or, } \\
\text { if no comparable private firm exists, higher than the average cost of debt? }\end{array}$ \\
\hline \multirow[t]{2}{*}{ Other risk factors } & $\begin{array}{l}\text { Vulnerability. Does the SOE have sizable contingent liabilities, or is it a source of } \\
\text { contingent liabilities for the government, say, through guaranteed debt? Is there a currency } \\
\text { mismatch between revenues and debt obligations? }\end{array}$ \\
\hline & $\begin{array}{l}\text { Importance. Is the SOE large in areas such as debt service, employment, customer base? } \\
\text { Does it provide essential services? }\end{array}$ \\
\hline
\end{tabular}

Source: Based on IMF 2005.

changes in macroeconomic conditions, developments in the industry where the SOEs operate, and operational management of the SOEs. For key SOEs in Indonesia, the IMF used scenario analysis and stress tests to assess fiscal risks (box 5.4 outlines the methodology) (Verhoeven et al. 2008). ${ }^{10}$

\section{Developing a Dividend Policy}

Clear SOE dividend guidelines should be developed. Dividends paid to the government usually reflect the profitability of the enterprise and the need 


\section{Estimating Fiscal Risks of SOEs}

Quantification of risks requires the specification of the factors that can disturb (or shock) the fiscal accounts through their impact on SOEs. Risk factors include changes in the following sets of variables:

- Macroeconomic, including international commodity prices (especially for oil) and exchange and interest rates.

- Regulatory, including price regulations (those related to public transport and water, for example), but also the effect of entry and universal service obligations.

- Operational, including delays and cost overruns in the implementation of capital projects, factors that affect operational efficiency (such as poor decisions) and the acquisition and sales of assets.

- Sectoral, including sector-specific factors that drive demand, changes in market share, and the cost of production (competition and wages, for example).

- Force majeure, such as natural disasters and other uncontrollable risk factors.

The impact of these factors on the fiscal accounts can be captured through various measures. In particular, fiscal risks can be assessed through the impact of risk factors on the following variables:

- Net contribution of the SOE to the budget, including through indirect taxes, corporate income tax, dividends, subsidies, net equity and debt payments, and calls on government guarantees. Net contribution measures the SOE's direct impact on fiscal revenue and spending.

- Financing need of the SOE. This measure complements the previous one, since the SOE can offset the impact of a risk factor on its net contribution to the budget by taking on additional debt. But that additional risk also reduces the scope for net contributions in the future, all other things being equal. The financing need can be measured on a net basis (that is, not taking into account debt rollover) or on a gross basis (this is useful particularly when debt rollover is at risk).

- Net debt. This measure indicates total liabilities minus current assets of the SOEs. Rising net debt increases the exposure of the government to adverse shocks on the SOEs' balance sheet and operations (that is, through the government's need to provide financial support to the company and the likelihood of reduced net contributions to the government's budget in the future). 
BOX 5.4 continued

- Off-balance-sheet liabilities. An example is a guarantee (such as for toll road revenue) under a public-private partnership contract. Offbalance-sheet liabilities are typically of a contingent nature (if they are direct liabilities they would likely be included in liabilities on the balance sheet). This measure adds to the previous measures, because, for the government, an increase in off-balance-sheet liabilities has an impact on the SOE's net worth similar to an increase in net debt.

These measures are largely complementary, and it is not possible a priori to determine which is more important. When the government faces liquidity constraints, it may be most concerned about the net contribution to the budget. If firm debt is seen as a critical problem for the SOE sector (because of worsening payment arrears of SOEs, for example) or there is substantial borrowing by SOEs under government guarantees, then the focus may be more on financing need and net debt. Source: Verhoeven et al. 2008.

to retain profits for investment in capital assets. Higher dividends may not always be desirable, as they may reflect monopoly profits or deprive SOEs of funds they may require for investment in new capital assets. As an alternative to dividends, governments may establish a policy of retaining funds in the enterprise to increase shareholder value.

A dividend policy for SOEs would divide its after-tax profit into two parts: retained earnings to finance investment and dividends to finance general public spending by the government. As such, the rationale for a sound dividend policy is twofold: first, it has the potential to enhance the efficiency of investments financed by the retained earnings of SOEs; and second, it may improve the overall allocation of financial and fiscal resources (Kuijs, Mako, and Zhang 2005).

Large-scale financing of investment through retained earnings may facilitate SOE expansion because of the readily accessible source of finance. However, this pattern of financing has disadvantages that grow more prominent as the economy develops and becomes more sophisticated. The critical disadvantage is that within-firm allocation of capital does not receive the same scrutiny as financing from the financial sector. If the firm's prospects for growth and profitability are good and corporate governance is strong, within-firm allocation of at least some of the profits 
can be optimal. However, if the prospects for growth and profitability decline and if corporate governance is weak, the likelihood of inefficient within-firm allocation increases, and payout of at least some profits to shareholders is probably warranted.

SOE dividend policies vary among countries. In New Zealand, as in many other OECD countries, SOE boards set dividend policies in consultation with the shareholding ministries, based on such factors as the SOE's capital structure, proposed capital investments, and profitability. In Singapore, SOE payouts are based on cash flow (that is, on predepreciation earnings). In Norway and Sweden, SOEs have occasionally returned capital to the state in the form of a special (one-time) dividend to reduce capital (equity) and achieve a higher rate of return on capital invested.

In most countries, the general practice is for SOE dividends to be paid to the finance ministry for general public uses, regardless of which government department acts as the state shareholder, as dividends are considered public financial revenues and should be managed as such. Countries with separate ownership agencies or holding companies (see chapter 3) may receive SOE dividends and retain a portion for reinvestments in SOEs, but even so a share of dividend payments is usually made to the finance ministry. In Singapore, for example, Temasek's returns are generally retained for reinvestment, but payments to the Finance Ministry have averaged 7 percent of the market value of Temasek's shareholdings over the past 30 years. In some cases, dividend payments from the ownership entity to the finance ministry may be based on a fixed percentage that the entity itself receives from SOEs in its portfolio, or on a percentage of the capital employed by the SOEs in the ownership entity's portfolio, or some combination of the two (Kuijs, Mako and Zhang 2005). Strengthening corporate governance and dividend policy should lead to greater scrutiny of capital allocation, making it more difficult for managers to invest in bad projects and enhancing shareholder wealth while minimizing the financial and fiscal risks of SOEs. Profitable SOEs should provide funds for public spending to improve the equity of key public services, such as education and health.

\section{Using Markets as an Information Source}

Markets can provide useful independent metrics of the financial position and fiscal risk of SOEs by listing SOE debt or some company shares. If SOEs issue bonds, they will be exposed to the risk perceptions of the market and credit rating agencies. The resulting market information can help raise debt through SOE bonds, relieving the government of having to use sovereign debt and then on-lending to the SOE. In the case of Chile, state-owned banks 
are prohibited from lending to the government or SOEs altogether. Meanwhile, New Zealand's SOEs have freedom over all pricing, investment, and debt-raising decisions, but in return they are expected to maintain a minimum BBB credit rating. (It should also be noted that their debt is explicitly not guaranteed by the government.)

Many Brazilian and some French SOEs are listed on the stock exchange. The major Zambian mining holding company, ZCCM-IH, which is 87 percent government owned, is listed on the local and London stock exchanges. Almost all Chinese companies listed on the Shanghai stock exchange are majority owned by the government, and on the Hong Kong exchange, SOEs comprise some 25 percent of market capitalization.

Establishing SOE Debt Management Policies. Monitoring SOE debt should be integrated into the government's general fiscal policy analysis as a source of fiscal risk, where appropriate. Governments should implement measures to oversee, limit, or monitor the debt accumulated by SOEs when the amount of overall public sector debt is a concern. The IMF suggests that legislation on public debt cover all debt transactions and government guarantees, including those arising from SOEs (2007) (box 5.5). It is a particular challenge for governments to maintain a balance between reasonable oversight of SOE finances and respecting SOEs' autonomy in their business decisions. In addition to creating a strong institutional and statutory framework governing SOE indebtedness, countries should trust the government to act as a responsible shareholder (chapter 3 ) and ensure that the SOE is led by an active and competent board of directors (chapter 6).

Analysis of debt sustainability is commonly conducted for the sovereign debt of developing countries, usually as part of IMF and World Bank programs. However, this analysis generally does not cover SOE debt. Analytical tools that project SOE profitability in relation to debt levels can help determine the sustainability of SOE debt. The IMF has developed such tools; sometimes termed "stress tests," they are particularly well developed for assessing the financial soundness of SOE financial institutions. These tests may be conducted by the authority responsible for surveillance of the banking system.

Fiscal management requires public debt policy to have a legal basis supported by clear secondary regulations (see table 5.2). A public debt law (or other primary legislation) should clearly define all SOE debt limits and monitoring arrangements. These may include three important elements: (1) restrictions on the type of instrument that can be used for debt management, risk parameters, and the content of a medium-term debt management strategy; (2) methods for analyzing contingent liabilities and the risk that 


\section{BOX 5.5 \\ Good Practices for Institutional Arrangements and Reporting Mechanisms for SOE Debt}

- Clearly defined and legally backed institutional arrangements for SOE debt monitoring are critical.

- Legislation and government regulations need to define the primary data sources and specific indicators to be used for monitoring contingent liabilities originating from SOEs.

- Coordination mechanisms and information flows need to be transparent and streamlined to ensure efficiency and confidentiality of information, as appropriate. Care should be taken to avoid duplicate lines of reporting to reduce the overall administrative burden for SOEs and government agencies.

- Laws and regulations should stipulate which government agency is responsible for primary data collection and analysis of SOE debt. Alternatively, one unit (for example, within the ministry of finance) can be responsible for data collection, consolidation, and analysis.

- Financial monitoring should be seen as a proactive process (as opposed to data gathering for its own sake) and supported by appropriate financial-monitoring tools.

TABLE 5.2 Examples of Controls over SOE Indebtedness

\begin{tabular}{ll}
\hline Country & \multicolumn{1}{c}{ Control } \\
\hline Brazil & Ex ante approval is required for foreign borrowing by SOEs. \\
Canada & The Treasury Board reviews all SOE corporate borrowing plans. \\
Chile & All borrowing and debt issued by SOEs require authorization by the Ministry of Finance. \\
France & Indebtedness is one of three key SOE performance indicators monitored by the ownership entity. \\
India & There is a three-tiered system for SOEs, which links SOE performance to higher levels of \\
& autonomy, including greater autonomy to raise debt. \\
Spain & SOEs come under the state holding company, SEPI, which has financial autonomy but whose \\
& $\begin{array}{l}\text { borrowing capacity is limited by the budget law. SEPI exercises fiscal oversight over SOEs } \\
\text { through the review of the annual operating plan and the four-year multiyear business plan. }\end{array}$ \\
& $\begin{array}{l}\text { Debt operations outside the annual operating plan must be submitted to SEPI for prior approval. } \\
\text { Large SOEs (more than US\$1.6 billion in assets) are required to submit a five-year financial } \\
\text { management plan, including a debt management plan, to the minister of finance. SOE debt will } \\
\text { be included in the new national debt management plan required by the Finance Act. This includes } \\
\text { improving SOE financial results and position, considering asset sales, and limiting interest costs } \\
\text { as a proportion of total costs, which, in effect, would set debt ceilings for SOEs. }\end{array}$
\end{tabular}

Source: World Bank staff. 
government guarantees will be called; and (3) the accounting standards and reporting and audit requirements. Regulations should also define the responsibilities of the debt management unit. Any limits, ceilings, or other direct controls should, as a general rule, be reserved for sectors or specific SOEs where risk is deemed high.

\section{Managing Debt Guarantees}

As a general rule, the state should not provide automatic guarantees to back up SOEs' liabilities. The New Zealand government has explicitly affirmed that it does not guarantee SOE debt; and such explicit declarations are a good practice for mitigating fiscal risk. However, in practice, these declarations may not eliminate the perception of an implicit guarantee, unless backed up by clear refusal to make payments in the event of SOE default. ${ }^{11}$

If a state guarantee is provided, fair practices on the disclosure and remuneration for the guarantee should be implemented. For instance, as reported by OECD (2011a), the Australian authorities have implemented an innovative mechanism for calculating such remuneration. It relies on a credit evaluation performed by a debt-rating agency under the assumption that the SOE's ownership was private. The so-called debt neutrality charges are calculated as the difference between what the entity would pay if privately owned and what was actually paid.

International good practice suggests that all guarantee proposals, including guarantees of SOE debt, be subject to scrutiny and appropriate prioritization to balance insurance and incentive considerations. Mechanisms used include guarantee fees, partial guarantees, and quantitative ceilings on guarantees. IMF (2007) suggests that the authority for granting government guarantees legally rests with a single official, usually the minister of finance or the head of the agency responsible for debt management. Guarantee amounts should have clearly specified monetary limits. And if limits on guaranteed debt are set out in law, that legislation should include clear criteria for consideration and approval.

In some countries, approval by the minister of finance is required if the guarantee authorization is contained in the annual budget law. In other countries, the legislature must approve all government guarantees as part of the budget process. Including guarantees in the budget process ensures that the costs are internalized, thus reducing the bias in favor of guarantees over conventional expenditures. When guarantees are not intended as subsidies, several countries (Canada and EU countries, for example) charge the recipient a fee that reflects the guarantee's market value. When guarantees are indeed intended to provide a subsidy, a number of countries (such as Canada, 
the Netherlands, Sweden, and the United States) charge fees against the budget of the sponsoring line ministry. These fees reflect the expected net present value of the long-term cost of the guarantee.

\section{Monitoring and Disclosure of Contingent Liabilities}

A few countries have provisions in their budgets for contingent liabilities, including those associated with SOEs. Government budgets typically have a general contingency reserve for urgent and unforeseen expenditures-which may be inadequate-including for meeting contingent liabilities. Canada has a provision for the contingent liabilities of SOEs in its financial statements. In Canada's 2009-10 financial statements, a provision of Can $\$ 50$ million was made for payment of guaranteed borrowings of crown corporations. This provision took into consideration the nature of the loan guarantees, past loss experience, and current conditions. The allowance is reviewed on an ongoing basis, and changes in the allowance are recorded as expenses in the year they become known (Canada 2011).

Most countries, however, do not systematically report contingent liabilities (Mihaljek 2007):

- Contingent liabilities are estimated but not included in the accounts of Brazil, Chile, Colombia, India, Israel, Mexico, Peru, the Philippines, Poland, and South Africa.

- Contingent liabilities are not quantified in the accounts of Argentina, the Czech Republic, Hungary, and Thailand.

- Contingent liabilities are shown as a balance sheet item in the accounts of Indonesia and the Russian Federation.

According to broad international agreement, governments should report their contingent liabilities to the extent that they can be predicted and quantified. As good practice dictates, the nature of the contingent liability should be described along with the estimated present value, if practicable, of any payment on a risk-assessed basis. The International Public Sector Accounting Standards require the disclosure of contingent liabilities as a note on a government's financial statements. Some countries, such as New Zealand, also disclose unquantifiable contingent liabilities in narrative form in the notes to the financial statements.

There are a number of options for disclosing the fiscal risk associated with contingent liabilities. It is regarded as good practice, as set out in the IMF's Manual of Fiscal Transparency (IMF 2007), to prepare a statement of fiscal risks, including contingent liabilities arising from SOE debt, as part of the budget documentation. In fact, a number of countries (including 
Australia, Brazil, Chile, Colombia, New Zealand, and Pakistan) consolidate information on fiscal risks as part of their budget documentation. For each type of risk, the statement may discuss past realization and forward-looking estimates, providing background to policies aimed at reducing such risks in the future. Frequent bailouts of SOEs call for strengthening central monitoring and control of their activities. ${ }^{12} \mathrm{~A}$ big risk from unrecorded contingent liabilities is that, should they materialize, these liabilities can suddenly cause government debt to balloon, which may jeopardize debt sustainability.

When contingent liabilities become actual (or likely), they should be recognized as such. According to the International Public Sector Accounting Standards, if the probability that payments will be made is more than 50 percent and they can be reliably estimated, then such payments should be recognized in the financial statements as a liability. According to IMF (2007), when it is clear that an SOE is unable to meet a repayment obligation guaranteed by the government, the loan should be recognized as a government liability rather than as a contingent liability. However, a key requirement for reporting on the fiscal risk arising from SOE debt is having reliable information on total SOE debt and its composition, which may be problematic.

In several countries, risk mitigation includes a requirement that the private sector bear a share of the risk from contingent liabilities. Such risk sharing may be achieved by providing only partial guarantees, which increases the incentives of private sector lenders to assess the creditworthiness of projects and borrowers. For example, in Canada and EU countries, private sector lenders bear 15-20 percent of the net loss associated with any default. Other risk-sharing arrangements include time limits for contingent claims, clauses allowing the government to terminate the arrangement when it is no longer needed, and requirements for recipients to post collateral, as in Australia.

\section{Notes}

1. For instance, the president of Blue Star, China's industrial cleaning company, explains how the company was transformed into that nation's largest chemical conglomerate through the acquisition of more than 100 SOEs (Koch and Ramsbottom 2008).

2. Quasi-fiscal liabilities in Bangladesh usually involved state-owned financial institutions.

3. Commission Directive 80/723/EEC of June 25, 1980, addresses the transparency of financial relations between member states and public undertakings.

4. See regulation (EC) no. 1370/2007 of the European Parliament and of the Council of October 23, 2007, on public passenger transport services by rail and 
by road, and repealing Council Regulations (EEC) No 1191/69 and (EEC) No 1107/70).

5. Oportunidades in Mexico and Bolsa Familia in Brazil are two examples of successful conditional cash transfer programs.

6. For a detailed description on the relevance of competition impact evaluation and how to perform it, see OECD (2007) and CNC (2009).

7. For Croatia, a similar situation exists. In 2008 and 2009, the operating subsidies to the rail system represented 0.12 percent of GDP (World Bank 2011).

8. The International Accounting Standards Board recently issued a practice statement on the management commentary. See www.ifrs.org.

9. Corbacho (2007) assesses these criteria for two public transport SOEs in Hungary.

10. This methodology was also used by Riveira, Verhoeven, and Longmore (2014) for fiscal risk analysis of SOEs in Jamaica.

11. An OECD (2011a) report provides as an example the situation in the 1990s when the U.S. government tried "on several occasions to raise the funding costs of the government sponsored entities Fannie Mae and Freddie Mac by publicly declaring that these institutions would not be subject to a government bail-out in case of failure."

12. Unanticipated needs to refinance SOFIs are an example of such fiscal shocks, even contributing to financial and currency crises such as the one in East Asia in the late 1990s.

\section{References}

AIC (Australian Industry Commission). 1994. Community Service Obligations: Some Definitional, Costing and Funding Issues. Canberra: Australian Industry Commission.

Canada. 2011. "Financial Statements of the Government of Canada and Report and Observations of the Auditor General of Canada." In Public Accounts of Canada 2011, Vol. 1. Ottawa: Minister of Public Works and Government Services Canada.

CNC (Comisión Nacional de la Competencia). 2009. Guide to Competition Assessment. Madrid: CNC.

Corbacho, Ana. 2007. "Hungary: Fiscal Risks from Public Transport Enterprises," Magyar Nemzeti Bank Conference Volume 1 (1): 28-42. http://english.mnb.hu /Root/Dokumentumtar/ENMNB/Kiadvanyok/mnben_egyebkiad_en/mnben _temporary_measures_2007/ana_corbacho.pdf.

IMF (International Monetary Fund). 2001. Governance Finance Statistics Manual. Washington, DC: IMF. http://www.imf.org/external/pubs/ft/gfs/manual/pdf /all.pdf.

—. 2004. Public Investment and Fiscal Policy. Washington, DC: IMF. https:// www.imf.org/external/np/fad/2004/pifp/eng/PIFP.pdf.

-2005. Public Investment and Fiscal Policy: Lessons from the Pilot Country Studies. Washington, DC: IMF. http://www.imf.org/external/np/pp/eng/2005 /040105a.pdf. 
2007. Manual on Fiscal Transparency. Washington, DC: IMF. http://www.imf .org/external/np/pp/2007/eng/051507m.pdf.

Koch, Tomas, and Oliver Ramsbottom. 2008. "A Growth Strategy for a Chinese State-Owned Enterprise: An Interview with Chem, China's President." McKinsey Quarterly (July). http://www.mckinseyquarterly.com /An_interview_with_ChemChinas_president_2157.

Kojo, Naoko C. 2010. "Bangladesh: Fiscal Costs of Non-Financial Public Corporations.” Draft paper, Economic Policy and Debt Department, World Bank, Washington, DC.

Kuijs, Louis, William Mako, and Chunlin Zhang. 2005. "SOE Dividends: How Much and to Whom?" Policy Note, World Bank, Washington, DC. http://www-wds .worldbank.org/external/default/WDSContentServer/WDSP/IB/2010/09/17 /000334955_20100917050418/Rendered/PDF/566510WP0SOE1E10Box353729 B01PUBLIC1.pdf.

Mihaljek, Dubravko. 2007. "Fiscal Transparency from Central Banks' Perspective: Off-Budget Activities and Government Asset Funds.” Magyar Nemzeti Bank Conference Volume 1 (1): 9-17.

OECD (Organisation for Economic Co-operation and Development). 2005. OECD Guidelines on Corporate Governance of State-Owned Enterprises. Paris: OECD.

—. 2007. Competition Assessment Toolkit. Paris: OECD.

-2010. Accountability and Transparency: A Guide for State Ownership. Paris: OECD.

—. 2011a. "Competitive Neutrality and State-Owned Enterprises: Challenges and Policy Options." Corporate Governance Working Paper 1, Organisation for Economic Co-operation and Development, Paris.

_. 2011b. Working Party on State Ownership and Privatization Practices. Competitive Neutrality in the Presence of SOEs: Context and Proposed Next Steps. DAF/CA/SOPP (2011). Paris: OECD.

- 2011c. Working Party on State Ownership and Privatization Practices. Competitive Neutrality in the Presence of SOEs: Practices in Selected OECD Countries. DAF/CA/SOPP(2011). Paris: OECD.

Raham, M. Azizur. 2012. "Sinopec Seeking Sales Rights to Third Party.” Financial Express, June 4.

Rice, Xan. 2012. "Nigeria Power Rates to Rise up to 88\%." Financial Times, February 12.

Riveira, Marta, Marijn Verhoeven, and Rohan Longmore. 2014. "A Framework to Assess Fiscal Risks of Public Bodies: Application to Eight Selected Public Bodies in Jamaica." World Bank: Washington, DC.

Verhoeven, Marijn, Eric Le Borgne, Paulo Medas, and Leroy Jones. 2008. "Indonesia: Assessing Fiscal Risk from State-Owned Enterprises." IMF. Washington DC.

World Bank. 2011. "Railway Reform in South East Europe and Turkey: On the Right Track?” Annex 1. Washington, DC: World Bank. http://ec.europa.eu/transport /rail/studies/doc/2011_03-railway-reform-south-east-europe-and-turkey.pdf. 



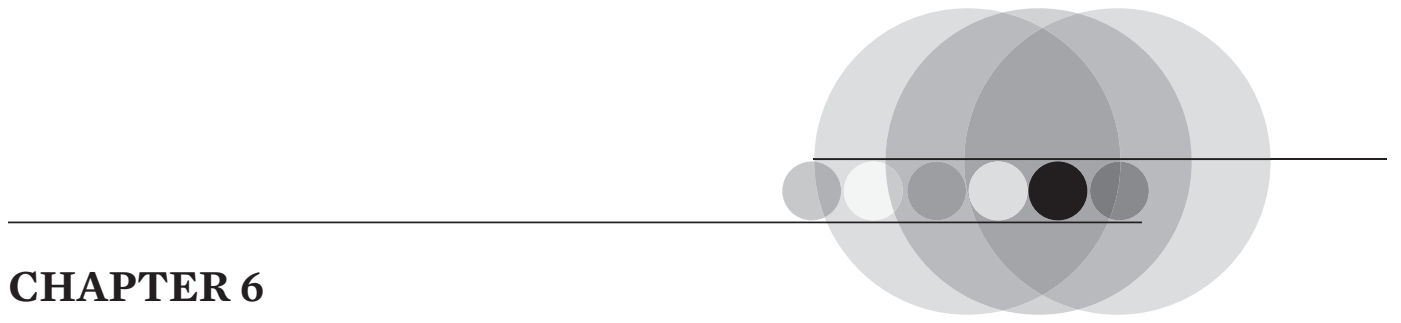

\section{Board of Directors}

According to good practice, the board of directors of any company, including state-owned enterprises (SOEs), plays a central function in the governance of that company. Because the professional board bears the ultimate responsibility for the stewardship and performance of the company, its composition and functioning have a significant impact on the governance of the SOE and therefore on its operational and financial performance. An effective board must comprise highly qualified and competent directors capable of exercising objective, independent judgment to guide strategy development and monitor management. The board, company executives, and external stakeholders must share a proper understanding of the role and responsibilities of the board to ensure that the board has appropriate autonomy, authority, and accountability in exercising its functions. Moreover, an effective board follows operating practices-such as creating board committees and providing specialized training and evaluation for directors-that improve board functioning and decision making.

This chapter describes the key steps in improving SOE boards:

- Professionalizing board composition

- Defining and implementing board responsibilities. 
- Enhancing board professionalism

- Setting board remuneration and evaluation procedures

- Providing training for board directors

Annex 6A provides a summary matrix to diagnose where the board of directors of an SOE stands and to offer guidance on progressive reform steps for improving SOE boards. The matrix covers the main elements of boards as set out in this chapter.

\section{Key Concepts and Definitions}

The term board of directors refers to the governing body of an incorporated organization such as an SOE. The exact role of the board differs by jurisdiction and may also be different for state-owned enterprises from that of private sector companies. In a one-tier system, a single board of directors provides strategy and oversight of the company. Its board may be composed either entirely of nonexecutive members (that is, members who are not part of the senior management), of a combination of executive and nonexecutive members, or, in rare cases, of executive members only. In jurisdictions with a two-tier system, the SOE has both a supervisory board and a management board. The supervisory board, usually composed entirely of nonexecutive directors, oversees the management board, which consists of the enterprise's senior management team. For companies with a two-tier system, discussion of the board of directors in this chapter refers to the supervisory board. It is understood that the second board will carry out management functions and possibly some functions that executive directors might undertake in a onetier board.

The duties of directors in relation to a company are commonly understood to include a duty of care and a duty of loyalty to the company (box 6.1). Collectively, these are known as a director's duties. The duty of care is an obligation of due diligence when performing acts that could potentially harm shareholder interests. The duty of loyalty refers to the obligation of directors to act in the interest of the company and all its owners.

An important distinction should to be made between board nomination and board appointment. First, a potential board member is nominated, usually by a shareholder, such as an ownership entity or line ministry, by a specialized committee, or by the board. The act of appointing a nominated director to the board is a subsequent step carried out by a government authority or the general meeting of the company. 
BOX 6.1

\section{Duties of Care and Loyalty: Implications for SOE Board Members}

Boards of directors have two principal fiduciary duties toward the company: the duty of care and the duty of loyalty. These duties have implications that can pose particular challenges for SOE board members:

- The duty of care is an obligation to exercise reasonable diligence and care in performing acts that could potentially harm shareholder interests. This duty requires board members to inform themselves on all issues that could affect the SOE and to make fully informed decisions. One practical implication is that board members need to satisfy themselves that control systems are functioning properly and providing good information. The duty of care also requires that board members act professionally, avoid serving on too many other boards, and receive adequate training and other support.

- The duty of loyalty is generally defined as a duty of allegiance to the SOE and its interests. A common interpretation is that this duty requires board members to raise the value of the enterprise for its owners. In addition, it requires board members to prevent their personal interests from prevailing over the interests of the SOE or its shareholders. Nor should board members allow the interests of others-including managers, other board members, and prominent government or political officials-to prevail over those of the SOE.

\section{Duties Increasingly Explicit}

Once implicit and dependent on legal precedent in many countries, these duties are increasingly explicit in company law. This is true both in common law countries, where these duties originated, and in civil law countries, where the duties must be explicit in law to have legal standing. For SOEs that come under company law, their board members should also be legally bound to carry out these duties. If an SOE does not set out explicit legal duties for board members, these duties should be covered in a code or policy that applies to the SOE.

(box continues on next page) 
BOX 6.1 continued

\section{Challenges in Implementation}

Carrying out these duties can be challenging in an SOE. The government may request policy or social outcomes contrary to the interest of the SOE. The board members may be government employees and therefore have conflicting loyalties. They may lack the skills to fully implement the duty of care. Effective implementation requires following the guidance touched on in this chapter and other parts of the toolkit, including care by board members to declare and manage conflicts of interest.

\section{Implications}

One implication of explicit legal duties is that they require board members to act in the interest of the shareholders as a whole and avoid treating any group of shareholders unfairly-clearly a challenge when the controlling shareholder is the state. Chapter 8 describes steps that should be taken to protect the rights of nongovernment shareholders.

Another implication is that board members may be sued for taking negligent actions or those not in the interest of the company. For members of private sector boards, the possibility of being sued-whether by shareholders, the company, or regulators-varies widely. Practically unknown in some countries, such suits are common enough in others that board members feel compelled to take out insurance against them. For SOE board members, liability varies even more. Those who are civil servants may have no liability or have distinct liability as government or state employees. In some jurisdictions, those who are not civil servants may still be treated as state employees and have a related liability. This liability depends very much on the legal framework for SOE and government employees. SOE board members may also face the possibility of investigation by state auditors, anticorruption bodies, or other state vigilance entities.

\section{Professionalizing Board Composition}

Good practice boards require that members who act in the interest of the company face no conflicts of interest in such actions and have relevant experience and expertise, including in the private sector. In addition, as recommended by good practice, many boards have sought to increase their objectivity by bringing in independent directors and by having a chair separate from the chief executive officer (CEO). 
Contrary to good practice, however, SOE boards are often composed of government, political, and stakeholder representatives with limited commercial or financial knowledge or experience, who are therefore unsuited to exercising the kind of responsibility increasingly required of SOE boards. Boards may comprise ministers and other politically connected persons, party leaders, elected officials, and civil servants who may excel at ensuring that the SOE is attentive to political or policy goals; but they may pursue those goals to the detriment of the economic and financial health of the SOE. Moreover, without the required technical and business experience, directors may be unprepared to exercise the full range of responsibilities of a professional board member. For example, their knowledge of risk management or internal control and audit may be insufficient to effectively monitor management or provide strategic guidance. Staffing a board with unsuited directors can also compromise the board's objectivity and independence, leaving it beholden to individual politicians and government officials and unable to act in the SOE's best interests.

Such problems often stem from the lack of clear policies or guidelines for nominating and appointing qualified members to SOE boards-even when such nominations and appointments are covered by SOE legislation and by the companies' constitutional documents. In the absence of clear policies, the process can be fraught with pitfalls: politicized appointments, lack of clear selection criteria, appointment delays, ad hoc and diverse practices among ministries, and lack of transparency.

For these reasons, many countries are taking steps to improve board composition by designing a robust policy framework and clear processes for board nominations and appointments. They are thereby seeking to depoliticize the process, make it more professional and transparent, and ensure that boards have the competencies and objectivity needed to carry out their duties. Such a framework includes several critical elements:

- Creation of balanced boards

- Adoption of professional criteria for the selection, and removal, of board members

- Development of a structured nomination process

- Timely appointment and public disclosure of the results

\section{Creation of Balanced Boards}

A typical board usually consists of three different types of directors: (1) executive directors, who are the CEO and other senior full-time executives of the company; (2) nonexecutive directors, who are not part of the 
executive team or are not employed by the company; and (3) independent directors, who in the purest form are directors with no material relationship to the company. Modern good practice suggests that boards are increasingly introducing independent directors to enhance objectivity and independence.

In the case of SOEs, board composition varies by country and by type of SOE, by size and complexity, and by being listed or not listed on the stock exchange. However, many SOE boards still primarily comprise executive directors and nonexecutive directors who are mainly government representatives. Government representatives are most often civil servants, who can be from the ownership entity or from other ministries. In some cases, ministers and other political appointees may also sit on SOE boards. Nonexecutive directors from the private sector, academia, think tanks, and other external sources may be appointed as representatives of the state, but this type of appointment is not very common. In some countries, employees are also represented on the SOE board (box 6.2).

\section{BOX 6.2 \\ Employee Representation on SOE Boards in OECD Countries}

In countries in the Organisation for Economic Co-operation and Development and non-OECD countries, employees are represented on SOE boards as a way to bring their knowledge to the table and to ensure that their concerns as key stakeholders are represented. Employee representatives bring employment and social issues to the table and can be a primary source of information that is independent from senior management. In some countries, lack of employee involvement in board decisions has resulted in tension when decisions were brought to the workplace.

In many cases, the presence of employee representatives on SOE boards derives from usual corporate practice in the countries concerned, such as in Austria, the Czech Republic, Denmark, Finland, Germany, and Norway. In other cases, employee representation is required by legal statute, as in France, Greece, Israel, Slovenia, Spain, Sweden, and Switzerland. In other cases, SOE laws stipulate their inclusion. In still others, such as Chile, employee representation on a few statutory corporations' boards is based on the SOEs' own statutes. In non-OECD 
BOX 6.2 continued

countries, employee representation on boards is found in China and Egypt, for example.

While employee representation is common in these countries, practices differ somewhat. For example, in both Israel and Slovenia, employee directors are subject to the same duties and responsibilities as any other board member. However, Israel has stronger mechanisms for ensuring the nomination of the most suitable individuals: employees elect a pool of candidates from which the owner picks two. In Slovenia, one-third of the supervisory board is appointed directly by the SOEs' work councils.

In general, most countries report that employee representation on boards contributes to improved company performance. Special care, however, needs to be exercised to ensure that employee representatives are sufficiently well qualified to play an equal role with other directors and to prevent their "capture" by stakeholder interests. Employee representatives should be selected through transparent and democratic processes involving all company employees. Qualities such as competence and independence of employee representatives should be sought.

Source: OECD 2013.

Reducing Government Representation on Boards. Boards composed mainly of government representatives lack the objectivity and skills vital to well-functioning boards. They are often appointed to pursue policy goals and in some cases to compensate for shortages of appropriately skilled directors from the private sector. But their appointment raises a number of issues. They typically lack the independence and the necessary qualifications and skills to be effective board members. Confusion among board members over which hat a government representative may be wearing could give rise to conflicts of interest. Their presence may distort board deliberations and give them a disproportionate influence in board discussions. When a government representative is appointed directly from the relevant line ministry, the board is more vulnerable to conflicts of interest, and the appointee may be motivated more by a desire to please the shareholder than by acting in the best interests of the SOE. Together, these factors weaken board autonomy, accountability, and access to relevant industry and specialized skills. 
For these reasons, more and more countries are taking steps to restrict the appointment of government representatives and, where they are appointed, to ensure that they meet the necessary qualifications and have the same obligations and roles as any other board member. Countries are taking several key steps to address these issues:

- Prohibiting ministers and other political appointees from serving on boards, as is the case in many Organisation for Economic Co-operation and Development (OECD) and non-OECD countries.

- Restricting the number of government representatives on boards while increasing the share of private sector members. In India, for example, SOEs are permitted to have a maximum of two government representatives on the board, usually civil servants from the relevant ministry.

- Prohibiting government officials who have a regulatory role from serving on boards. In Malaysia, to make government-linked corporations (GLCs) more independent from politics and to increase their business orientation, government officials with a regulatory role have been removed from company boards.

When the appointment of government representatives is allowed, however, good practice suggests that additional safeguards be put in place:

- The appointment should be made to a board where no conflict of interest will arise.

- The appointment should be made on the basis of the relevant skills.

- The appointment should be made in the person's own right, and the delegation of the role to other officials should be prohibited.

- The appointee should be subject to the same performance evaluation as other directors, including removal if deemed necessary.

- The appointee should share the same liabilities and reputational risks as other directors.

- The appointee should be responsible for maintaining the same skills and governance competencies as other directors.

- The appointee should be subject to the same terms of appointment as other directors.

- The appointee should not be made chair or deputy chair (Hamilton and Berg 2008).

Bringing in Independent Directors. In conjunction with restricting the number of government representatives, many countries are taking steps to increase the share of private sector members on SOE boards, particularly independent members-for listed and unlisted companies alike. 
The goal is to bring objective viewpoints and better governance skills to boards, to expand board willingness and ability to represent other stakeholders' interests, and to bring fresh views to strategic directions and market approaches.

Definitions of independence vary from one country to the next. However, what generally distinguishes nonexecutive from independent directors is any secondary ties they may have to the company or owner. For example, a nonexecutive director with business consulting contracts with the company would not be considered independent. Neither would a director who is a relative of the CEO or of a controlling shareholder. A detailed definition of independence is provided in box 6.3.

BOX 6.3

A Detailed Definition of an Independent Board Member

An independent director means a person who:

- Has not been employed by the company or its related parties, including its major shareholders, in the past five years.

- Is not an adviser or consultant to the company or its related parties and is not affiliated with a company that is an adviser or consultant to the company or its related parties.

- Is not affiliated with a significant customer or supplier of the company or its related parties, including banks or other financial institutions owned by any of the major shareholders.

- Has no personal service contracts with the company, its related parties, or its senior management.

- Is not affiliated with a nonprofit organization that receives significant funding from the company or its related parties.

- Is not employed as an executive of another company where any of the company's executives serve on that company's board of directors.

- Is not a member of the immediate family of an individual who is, or has been during the past five years, employed by the company or its related parties as an executive officer.

(box continues on next page) 
BOX 6.3 continued

- Is not, nor in the past five years has been, affiliated with or employed by a present or former auditor of the company or of a related party.

- Is not a controlling person of the company (or member of a group of individuals or entities that collectively exercise effective control over the company) or such a person's close relative, widow, in-law, heir, legatee, and successor of any of the foregoing or the executor.

Related party means, with respect to the company and its major shareholders, any person or entity that controls, is controlled by, or is under common control of the company and its major shareholders.

Source: IFC 2012.

Appointing independent directors enables SOE boards to operate at greater arm's length and address issues with unbiased judgment for the benefit of the SOE. ${ }^{1}$ Independent members can alter the board discourse, setting the stage for a more open discussion and allowing an opportunity for dissenting voices to be heard when key decisions are being considered.

Many countries have made it obligatory to have independent directors on SOE boards, for both listed and unlisted companies:

- In some OECD countries, such as Australia and Sweden, the great majority of SOE board members are independent. In these countries the definition of independence precludes government or political board members.

- In the Republic of Korea and Mozambique, a majority of directors have to be independent, including the chair.

- India and Malaysia stipulate that independent directors make up at least a third of the board in SOEs.

- Indonesia calls for a 25 percent share.

- A recent survey of development banks shows that 75 percent of boards surveyed include independent members and that in 30 percent of the banks independent members constitute the majority of the board. In a few cases, such as Slovak Guarantee and Development Bank and Antigua and Barbuda Development Bank, boards are composed entirely of nongovernment directors (de Luna-Martinez and Vicente 2012).

Steps in Transitioning to More Balanced Boards. While many countries have introduced requirements for independent directors, it is still not standard practice, and implementation of the requirements can be a challenge. 
Qualified independent directors may be in short supply, particularly in lowincome countries with a large public sector, although this shortage may sometimes be used as an excuse for not appointing independent directors. Changing the culture of boards can also be a difficult task in many environments.

The transition to appointing more balanced boards with the right qualifications, skills, and independence is therefore likely to be a gradual process, given these constraints. The progression matrix at the end of the chapter (annex 6A) highlights the progressive steps for moving from an acceptable level to best practice, for example:

- A first step could be to ensure that no ministers or elected officials serve on the board and that nonexecutive members have the necessary commercial and financial experience to serve.

- The next could be to include independent directors with private sector experience by phasing in one director at a time, starting with the most important SOEs. Over time, the independent representation could be gradually increased to a significant number of such directors and eventually to a majority of directors, including a chair who is independent of the government.

- In countries with a weak private sector, civil servants without conflicts of interest from other parts of the government and are not otherwise connected to the SOE could be allowed as an "independent" director on the board to bring a different perspective.

- Experienced foreign nationals-particularly for large and complex SOEs-may be considered as the pool of local talent grows. While the issue is often politically sensitive, foreign directors can increase the quality of the board, introduce new ideas and expertise, and help insulate SOEs from political interference and corruption, as foreign board members are less politically vulnerable.

Director development programs can also proactively expand the pool of qualified candidates. To minimize the potential risks arising from first-time directors, advisory bodies or centralized ownership entities could conduct governance development programs in which selected candidates learn the basics of serving on boards before taking up their appointment.

\section{Adoption of Professional Criteria for Selection and Dismissal of Directors}

As more and more countries move toward including independent directors and away from the practice of filling board positions with political 
figures and government representatives, professional criteria for the selection of directors become all the more important. While the specific skills required will vary from board to board, governments are identifying the competencies, skills, and experience needed to exercise independent judgment and lead the SOE successfully-including industry-specific knowledge and financial, legal, corporate governance, and other skills-and striving to appoint directors who match those profiles. The aim is to create professional boards with independent judgment and a wider range of talent and perspectives.

Selection Criteria. More rigorous qualifications have accompanied efforts to bring greater professionalism to the makeup of boards. In addition to minimum requirements for education and experience, industrial, financial, business, legal, and corporate governance skills, as well as private sector backgrounds and experience, are carrying more weight. Other skills such as integrity, ability to add value, and critical faculty are also important. While specialized expertise has been targeted for inclusion, certain backgrounds are also being identified to disqualify candidates (table 6.1).

\section{TABLE 6.1 Qualification Requirements for Board Directors}

\section{Priority \\ Example of qualification requirement}

Reduce participation by ministers and other high-level public officials.
Specific expertise required: Criteria may be the same for all SOEs or special criteria may apply only to certain SOEs or positions.

Skill set differentiation for particular positions or for the board as a whole
Estonia: Ministers and ministerial secretaries-general can serve on the boards of foundations but not companies.

Israel: Ministers, deputy ministers, and parliamentarians cannot serve as SOE directors; additional rules are established to prevent possible conflicts of interest.

Slovenia: High-level public officials cannot serve on SOE boards; and no more than two civil servants can serve on a supervisory or management board at any one time.

Czech Republic: Requirements include experience in corporate governance and knowledge of economics, financial statements, and the commercial code. Hungary: A degree in finance, economics, or law is required.

Romania: Most board members must have experience with profitable private sector companies.

Chile, Israel, and Lithuania: Additional proficiency and suitability requirements apply for candidate board members of large SOEs; the required expertise of each director position is specified to ensure that the board has an appropriate skills mix.

Switzerland: Qualifications are divided into three categories: (1) for the board as a whole (team functions, strategic skills, relevant market and professional knowledge); (2) for single board members (integrity, independence, professional skills); and (3) for the chair (specific leadership skills).

Source: OECD 2013. 
For state financial institutions, fit-and-proper criteria for the selection of directors and senior officers are especially important and are usually established, and vetted, by the central bank. Such criteria typically state that the directors shall have the requisite skills, experience, and knowledge to carry out their duties. The Bank of Thailand, for example, applies a fit-and-proper test to directors. More recently, the Thai Securities and Exchange Commission has also developed criteria for board members in all listed companies, including SOEs, to screen out those that have "untrustworthy characteristics.” These include insolvency, being named in a securities-related legal complaint, being recently imprisoned, or having caused damages to shareholders or other investors. The commission periodically releases the names of those who are not considered fit to be directors and maintains a list on its website of thousands of possible directors who are considered untrustworthy (World Bank 2012).

Profile of Board Skills. The sharper focus on the competency of boards is attracting greater attention to developing profiles of board skills as an important tool for better management of board appointments. These profiles detail the skills needed for a board as a whole or for particular positions (box 6.4). Such efforts have grown out of the need for government and its boards to bring greater professionalism to the makeup of boards, especially as they take on a bigger role in strategic business planning and in board evaluations. Because directors have finite terms, SOE owners need to be aware of the duration of all appointments and include succession planning in medium-term skills profiles. Developing a profile of board skills is especially important for the board chair and for specialist industry skills.

Dismissal Criteria. Board members should be appointed for a fixed term, usually one to three years. In many cases, even though board members have finite terms, they may be rotated or removed for no substantiated reasons, or, conversely, may be subject to unlimited renewals.

In both cases, clear criteria should guide the process for removing directors. Company legislation generally provides that shareholders may seek to remove a director. However, dismissal standards may need to be stricter for SOEs than for private sector companies to avoid the risk of arbitrary dismissals for political or other reasons unrelated to performance. A nonperforming director (for example, one who fails to attend board meetings) can jeopardize the health of the company, but a board member should not be subject to removal simply because of an election result. 
BOX 6.4

Developing a Board Skills Profile

Once a company has developed a strategic plan, the components of that plan are ranked in order of importance to maximize the value of the company's and shareholders' investments. The board documents the range and level of expertise required by the strategic plan. Generally, the board chair and appointments adviser (or similar) then review the individual and collective skills of board directors against the strategic plan to compile a profile of board skills. The profile indicates the duration of each director's term (and pending retirements) and identifies gaps in priority skills.

While directors may not be required to have detailed industry knowledge, they should have sufficient business and industry skills to assist in evaluating management's proposals. If a board determines it needs additional advice, it can engage external experts. (For instance, a director with a legal background is on the board to provide a broad understanding of the laws under which the SOE operates, not to act as the board's legal adviser.) Apart from industry skills, a board also needs to consider "soft" skills. Is someone needed who can strengthen the board's understanding of, say, a major ethnic group in the community? Does the board have a sound gender balance?

From this work, a skills profile will emerge. Ideally, before presenting this profile to the shareholding minister or ownership authority, the board appointments adviser will seek advice from analysts responsible for monitoring the SOE's performance. Their perspectives will improve the draft skills profile. Once approved by the SOE ownership authority, the skills profile-together with a description of the position and qualifications-will discipline the search for a director to fill any vacancy. Source: Hamilton 2011.

\section{Development of a Structured Nomination Process}

Especially under the decentralized model of SOE ownership, line ministries typically lead the nomination process for board directors. This approach can allow for considerable political influence and result in varied nomination procedures from one SOE to the next and a lack of transparency. $^{2}$ To reduce ministerial influence, a number of countries therefore have adopted governance reforms that delegate part or all of the 
nomination process to an advisory body, expert panel, centralized ownership entity, or the SOEs themselves.

Delegation to an Advisory Body or Expert Panel. An SOE advisory body may play an informal role, providing advice, as requested, to line ministries. But without a systematic structure or process in place, their role and inputs may be minimal. Giving them a more formal role in the process usually yields better results and helps improve the prospects of identifying more qualified and merit-based boards.

Advisory or coordinating bodies are assigned a formal role in countries such as India, New Zealand, Sweden, and the United Kingdom (box 6.5). In these cases, they usually prepare short lists of candidates, evaluate and propose candidates, maintain a database of potential candidates with different terms of reference, and keep records of board memberships and directors' terms.

A special panel or expert committee may also be created to provide supplementary advice for board nominations. Suitable panel members are usually experienced directors from the public or private sector:

- In New Zealand, before the government created COMU, the first minister for SOEs appointed a steering committee to give advisory support to shareholding ministers.

- Poland recently introduced an independent accreditation committee (OECD 2011). The committee recommends nominees to the Treasury for the supervisory boards of certain key SOEs, as well as dismissal of members when such a situation arises. The committee consists of 10 members who were recommended by key ministries such as treasury, economy, public finance, financial institutions, transport, communications and the president of the Polish Financial Authority and appointed by the prime minister on the basis of their knowledge and experience.

Control by Centralized Ownership Units. While advisory bodies typically support and advise line ministries on the nomination process, centralized ownership entities may have more direct responsibility for board nominations. Malaysia's Khazanah Nasional nominates and appoints board members of government-linked companies. In Chile, the Sistema de Empresas Council appoints and removes board members and also conducts annual board evaluations. Peru's FONAFE (the country's state holding company) appoints all board members for companies in its portfolio, while China's State-Owned Assets Supervision and Administration Commission (SASAC) directly appoints board members in 54 of the roughly 200 
BOX 6.5

\section{A Formal Advisory Body for Board Nominations: The New Zealand Example}

The appointment process in New Zealand varies somewhat for specific boards. However, the Crown Ownership Monitoring Unit (COMU), recently renamed Crown Operations, performs the following tasks for all appointments:

- Skills profiling. When a vacancy arises, COMU analyzes the board's makeup in conjunction with ministers and the chair of each company board. The goal is to determine the specific skills and experience that would be ideal in any new appointees. A position specification is then prepared.

- Candidate identification. Candidates may also apply directly for specific positions or register in COMU's appointments database to be considered for future opportunities. Ministers generally consult government colleagues for suitable candidates. Nominations from other agencies are requested as well.

- Short-listing. Ministers consider all applicants for each role and shortlist possible preferred candidates who appear to match the skill needs for each board.

- Due diligence and identification of conflicts of interest. COMU and the board chair form a view about each short-listed candidate, including a search for possible conflicts of interest (such as family connections, personal or professional links with the SOE or its management, or a directorship or ownership in another company that undertakes work for the SOE). When a conflict is identified, a decision is made whether the appointment can proceed in light of existing conflict-of-interest management rules or whether the conflict renders the candidate unappointable.

- Appointment. If the preferred candidate confirms his or her availability to serve on a board, the shareholding or responsible ministers advise the Cabinet Appointment and Honors Committee and the full cabinet accordingly. The appointment is confirmed by a notice of appointment to the successful candidate.

Source: COMU 2010. 
companies in its portfolio. ${ }^{3}$ Annex 6B lists guidelines for centralized management of the nomination process.

Responsibility of SOE Nominating Committees. The majority of countries rely on a top-down nomination process led by ministries, an advisory body, or an ownership entity. However, some use a bottom-up process led by the SOEs themselves. SOE-led nominations are more common in developed countries, for mixed-ownership companies, and for SOEs listed on an exchange with regulations that call for a board nomination committee (see section on board committees). Examples in Canada, Malaysia, and South Africa follow:

- In the case of financial SOEs, such as Canada's BDC and the Development Bank of South Africa (DBSA), the law establishes general fit-and-proper criteria for selection of board members, but board committees in both cases manage the nomination process (see box 6.6).

- In Malaysia the nomination committee of listed SOEs identifies potential board candidates (in conjunction with Khazanah and others), prepares the short list for approval by the board, and then submits the approved list to Khazanah for appointment.

\section{BOX 6.6}

\section{Board Nominations in Four State-Owned Development Banks}

A 2009 study looked at the mandates and governance of four wholly state-owned banks: Canada's Business Development Bank (BDC), Chile's BancoEstado, South Africa's Development Bank of Southern Africa (DBSA), and Finland's Finnvera plc. Three of the four banks are development banks; while BancoEstado is a commercial bank, it has a social objective.

BDC and DBSA operate with a one-board system and have a welldeveloped framework for the selection of board members. The law establishes general fit-and-proper requirements for selection of board members. In both cases, a board committee assesses the skill requirements for board members, recommends skill requirements for the selection of new directors, and assesses the capacities of the current board members. Professional headhunters typically prepare a short list of candidates, and the list is presented to the shareholder representative (the government). Although the

(box continues on next page) 
BOX 6.6 continued

government may decide not to select a candidate from the short list and appoint an outsider, shareholders have typically accepted candidates from the list. For one thing, when selecting outside candidates, the government is exposed to criticism for lack of transparency. For both banks, the chairman and the $\mathrm{CEO}$ are different positions. While no government officials participate on the board of BDC, the Ministry of Provincial and Local Government is represented on the DBSA board, although that ministry does not have a direct role in the ownership function. In neither case, however, is the CEO appointed by the board, which is an important shortcoming.

Finnvera and BancoEstado each have a two-tier board system, which includes a supervisory board and a management board (a board of directors in the case of Finnvera). Despite being elected based on political criteria, supervisory boards have limited responsibilities and have a more informational role, with relatively little if any political influence over the banks' decisions. Half of Finnvera's board is composed of government officials and the other half by representatives from the organizations in line with the company's industrial policy. While a board composition of this type may run the risk of appointing unqualified civil servants, in the case of Finnvera, the board composition has brought highly educated public servants and responsible and qualified representatives from trade unions. Cultural elements and a good corporate law help explain the effectiveness of the Finnvera approach, although this model is not advisable for countries with weak governance and legal frameworks. A good practice found in this case is that the CEO is appointed by the board. In contrast, the management board and the CEO of BancoEstado are selected by the president of Chile. Chilean presidents, however, have been careful to select individuals with technical capacity and political affinity with the government coalition. The model has worked well but is subject to weaknesses if the president changes the criteria for selection.

Source: Rudolph 2009.

An SOE-led process is potentially vulnerable to interference and manipulation of the nomination process. Short-listing can be influenced by the government, while a type of self-censorship may occur since the nomination committees may be reluctant to propose candidates that they know stand little chance of approval. However, integrating the SOE into the nomination process may help identify the backgrounds most needed in board directors. 
Below are some practical guidelines for SOEs to follow in leading the process for board nominations:

- Professionalize the search for qualified individuals led by a formal working group or independent nomination committee chaired by an independent director and consisting only of nonexecutive directors.

- Staff the committee with a majority of independent directors and employ independent external search consultants, as needed.

- Ensure that the nomination committee supports the objective of a formal, merit-based, and transparent process for the nomination of board members with specific skills.

- Advertise for candidates.

- Require that committee objectives and procedures be documented with full information on the process and that board nominees be made available to shareholders and the public.

- Audit the process.

Creation of a Directors' Pool. Ownership units in countries such as India and Thailand have generated databases of qualified candidates to assist in future nominations. Created by the advisory body or ownership entity, the databases are developed through open advertisement, specialized screening, search committees, the use of professional head hunters, and consultations with other ministries and government agencies. Candidates are prescreened and interviewed to ensure their competence and credibility. In Thailand, for example, the database includes over 500 persons. Criteria for selection are wide ranging and take into account Thai nationality, age, educational qualifications, work experience, integrity, and probity. Candidates cannot hold political positions or be affiliated with government administrations. The use of the pool is currently required for only one-third of nonstate board members, equivalent to one or two directors per board, although consideration is being given to increasing the proportion to at least half of all directors (World Bank 2012). There is little guidance from the State Enterprise Policy Office on the appointment of other board members. Such databases are one of the ownership unit's most valuable tools for professionalizing SOE boards.

\section{Timely Appointment and Public Disclosure of Results}

Once a candidate is selected, final appointment is usually authorized by the government and made by the shareholding minister responsible for the SOE. This can be another moment of vulnerability for a merit-based 
appointment process. However, a government persuaded of the importance of sound SOE governance will resist the urge to interfere with a professionally based selection. In many countries, company law and good practice require that appointments be made through the general shareholders' meeting. This procedure increases transparency and is particularly important when the company has nonstate shareholders.

Making timely decisions on the final appointment is important. Whether the process is driven by a centralized entity or managed by multiple ministries, bureaucratic processes and difficulties in reaching agreement on a candidate may cause delays. As a result, the board could be forced to operate with fewer members than normal, or the retiree's term may be extended month by month, both of which lead to board dysfunction.

Defined terms of appointment are also important. As a business evolves, the skills needed by the board may change too, requiring changes in board membership. In addition, defined terms ensure that directors do not adopt an "appointment for life" attitude, which may diminish their contribution. Boards tire, and this is another reason to limit the terms of appointment. Three-year terms are common, with renewal for a second term, or third term if an individual's presence is crucial to the business (Hamilton and Berg 2008).

Once the appointment decision is made, one of the final steps is to prepare the letter of appointment. Typically, this letter states the conditions of the appointment: the term, the expectations of the board and the director, and the details of remuneration, absences, and requirements for addressing potential conflicts of interest. Letters of appointment are important legal and accountability documents. The SOE board arranges for the new director's induction, including a copy of the director's manual. In addition, the advisory body or ownership entity may provide a sector induction program to outline the expectations of an SOE director, reporting regimes, and board and director evaluation (see "Setting Board Remuneration and Evaluation" below).

Greater public disclosure of information on the nomination process and the final appointments can help ensure professionalism and transparency. Emphasis on disclosing the nomination procedure itself and on the experience and background of selected candidates in the annual report or in the notice of the annual shareholders' meeting has increased; such disclosures allow the public and shareholders to assess the suitability and, if need be, the independence of each candidate.

In summary, whether led by line ministries, a centralized body, or by SOEs themselves, the process of nominating board members can be conducted professionally and lead to the appointment of qualified, competent, and objective SOE boards. Line ministries or councils of ministers may retain 
the final say on who is appointed. Yet, if the initial short list of candidates is established through a professional process based on the needs of SOEs and if the steps are carried out transparently, qualified and capable SOE boards will likely result.

\section{Defining and Implementing Board Responsibilities}

The board of directors has a specific function in the overall governance structure that includes the state (as owner), the board of directors, and management:

- As owner, the state establishes its overall "expectations" of SOEs and sets mandates or broad objectives for the SOEs it oversees.

- The board of directors sets the strategy for achieving the mandates or objectives, oversees the management, and monitors performance.

- The management is responsible for implementing the strategy and is accountable to the board.

In this structure, the board fulfills the central function in the governance of the SOE. As per the OECD, it has ultimate responsibility for SOE performance, for which it needs the authority, autonomy, and independence to make decisions that determine performance (OECD 2013). It also acts as the intermediary between the state (as the shareholder) and the management of the company and has a duty to act in the best interests of both.

Good practice as defined in the OECD's Guidelines on the Corporate Governance of State-Owned Enterprises (OECD 2005), calls for the board's role to be clearly defined and founded in legislation, preferably in company law. In practice, however, while SOE boards have broad nominal power, they are often not assigned specific responsibility in key areas, and the respective roles of the board and of the state as owner are blurred, or powers are explicitly reserved for the state when they should be within the competency of the board. Conversely, those responsibilities may be explicitly reserved for the ownership entity or another part of government. Indeed, the government is often given responsibilities as a matter of policy, thus compounding a lack of explicit responsibility for SOE boards. It may approve and influence SOE strategy, budgets, and major decisions; set performance objectives; select the CEO (and even other senior executives); and dictate human resource policy through statutes that make SOE employees quasi-civil servants. The government also may oversee board nominations, accounting, auditing, and conflicts of interest (although the 
presence of several monitors does not mean that these are managed or monitored particularly well). Even when boards have explicit responsibility, they may not be able to exercise it fully and may have little effective influence over their legitimate responsibilities: guiding strategy and major decisions, managing conflicts of interest, and choosing and overseeing the management of the SOE (box 6.7).

The government or ownership entity may have good reasons for establishing policy or standard procedures in many areas and even for being involved directly in some matters. ${ }^{4}$ Yet strategic and operational control by the government can lead to interference in fundamental company matters, with suboptimal results. Government intervention dilutes the authority of the board, undermines board accountability, and opens the door to political interference and a lack of focus on performance. It can also lead to

\section{BOX 6.7}

\section{Key Responsibilities of a Conventional Board}

- To review and guide corporate strategy, major plans of action, risk policy, annual budgets, and business plans; set performance objectives; monitor implementation and corporate performance; and oversee major capital expenditures, acquisitions, and divestitures.

- To set periodic review and monitor the effectiveness of the company's governance practices and make changes as needed.

- To select, define compensation of, monitor, and, when necessary, replace key executives; oversee succession planning.

- To set policy for key executive and board remuneration in line with the longer-term interests of the company and its shareholders.

- To ensure a formal and transparent board nomination and selection process.

- To monitor and manage potential conflicts of interest of management, board members, and shareholders, including misuse of corporate assets and abuse in so-called related-party transactions.

- To ensure the integrity of the SOE's accounting and financial reporting systems (including independent audit) and the operation of control systems such as risk management and financial and operational control; uphold compliance with the law and relevant standards.

- To oversee disclosure and communications.

Source: OECD 2004. 
less-motivated and engaged board members and create an opening for lead management to pursue conflicting objectives (those of government owners and those of the board).

Clarifying and implementing board responsibilities are therefore among the most important-and most challenging-aspects of professionalizing SOE boards. The key to ensuring that an SOE board can function effectively is a clear delineation of the respective roles of the state as a shareholder, of the board, and of management, including what the board is required to do and when the state, as owner, should provide explicit approval or oversight. These different responsibilities are usually established through laws, corporate governance codes and guidelines, or the companies' articles of association. In South Africa, for example, board responsibilities are based on the national corporate governance code for listed companies (public and private), with additional guidance provided for SOEs and the relevant ministry (box 6.8). Equally important is fulfillment of these different roles in practice to ensure accountability and to put the board to full use, as discussed below.

Practice across a range of countries suggests that as a board becomes more skilled, objective, and professional, it can take increasing responsibility

\section{BOX 6.8 \\ Delineation of SOE Board Responsibilities in South Africa}

The 2002 Protocol on Corporate Governance in the Public Sector sets forth the responsibilities of SOE boards in South Africa. The protocol functions in conjunction with the country's national corporate governance code-the King Code of Governance Principles-which applies to a wide range of enterprises, including listed companies. According to the protocol, "The board of the SOE has absolute responsibility for the performance of the SOE." The protocol also clarifies when the government shares power with the board. For instance, it notes that the board should consult with the "shareholder" (relevant minister) on the choice of CEO and that the shareholder should approve the pay of executive board members. The protocol specifies that the objectives of the shareholder compact-a performance agreement between the shareholder and the SOE-are to be the benchmark for measuring the performance of the company, the board, the chair, and the CEO. 
for the most important functions of any board: guiding strategy and major decisions, managing conflicts of interest, and overseeing the management and ultimately choosing the CEO. In each function, the board's role should evolve from passive oversight to guidance and appropriate involvement in the management and in the ownership entity. Thus, effective implementation of the board's responsibilities may also require reducing its role in operational details and secondary matters, thereby striking the right balance with management (OECD 2013).

\section{Guiding Strategy and Major Decisions}

Increasingly, SOE laws and national codes of corporate governance follow good practice and designate oversight of strategy and management as explicit board functions. But in practice, SOEs often develop their strategyas well as their budgets and business plans-in accordance with government policy or in conjunction with the ownership entity or another part of government. Because SOE budgets may have to be reported and approved as part of wider fiscal policy, they may therefore receive more attention than the overall strategy and corporate performance do. State planning agencies may also shape strategies and business plans, as in Thailand and Turkey. In its normal shareholder role, the ownership entity may approve or review major decisions-such as changes in capital structure-that require owner approval. State approvals have their place, especially when other accountability mechanisms are weak. But they can be time consuming and, more important, may limit the board's role and ability to make timely decisions.

As board capacity and overall SOE governance improve, the board's focus should shift to setting strategy and performance objectives, but it will need to be empowered by the ownership entity to do so. State approvals can be streamlined or eliminated in many cases, especially for contracts and other management decisions in the normal course of business, consistent with the broader guidance provided by the owner. Countries have begun to delegate major decisions to SOE boards, particularly those of larger SOEs or listed SOEs, but may still fall short of full delegation. In India, for example, greater authority is granted to the boards of larger and better-performing SOEs in important areas such as capital expenditures, joint ventures, and mergers and acquisitions, but in other areas boards may still have less say than recommended by good practice (box 6.9).

Although clarifying the roles of the owner and the board of directors in setting strategy and making key decisions is essential to setting clear 


\section{BOX 6.9}

\section{Delegating Decision-Making Powers to SOE Boards in India}

In India, delegation of board decision-making powers through guidelines issued by the Department of Public Enterprises (DPE) and as outlined by the corporate governance code for all public sector enterprises (CPSEs) owned by the central government, has helped empower the boards of CPSEs, especially the larger ones. A formal system of delegation, based on company performance, determines which decisions are the exclusive purview of the board and which must be shared with the relevant ministry (see table B6.9.1). Under this system, each SOE is classified on the basis of its size, profitability, and governance. As of 2008, the 5 Maharatnas and 16 Navratnas (the largest SOEs and among the largest companies in India) have the most freedom. Miniratnas, smaller companies, have somewhat less. Meanwhile, some powers are delegated to all profit-making SOEs. Thresholds for such actions as capital expenditures and joint ventures, subsidiaries, and mergers and acquisitions are set. Operations below the threshold require no approval by the ministry, while those above the threshold do.

TABLE B6.9.1 Thresholds Triggering Requirement for Ministry Approval of SOE Actions, India

\begin{tabular}{|c|c|c|}
\hline \multirow[b]{2}{*}{ SOE category } & \multicolumn{2}{|c|}{ Threshold } \\
\hline & Capital expenditures (U.S. dollars) & $\begin{array}{l}\text { Joint ventures, subsidiaries, } \\
\text { and mergers and acquisitions } \\
\text { (U.S. dollars) }\end{array}$ \\
\hline Maharatna & No limit & $\$ 1.1$ billion or $15 \%$ of net worth \\
\hline Navratna & No limit & $\$ 220$ million or $15 \%$ of net worth \\
\hline Miniratna (category 1) & $\$ 110$ million or $100 \%$ of net worth & $\$ 110$ million or $15 \%$ of net worth \\
\hline Miniratna (category 2) & $\$ 55$ million or $50 \%$ of net worth & $\$ 55$ million or $15 \%$ of net worth \\
\hline Other profit-making CPSEs & $\$ 33$ million or $50 \%$ of net worth & No specific delegation \\
\hline Other CPSEs & No specific delegation & No specific delegation \\
\hline
\end{tabular}

Note: $\mathrm{CPSE}=$ central public sector enterprise.

In practice, however, empowered boards may have little or no say in key areas such as appointment and removal of the CEO and, to a lesser extent, in strategy formulation-both being legitimate and fundamental board functions. In day-to-day decision making, except for investments, government is said to intervene in most matters such as creating posts or revising pay scales, pricing and marketing decisions, and dividend payments. In other CPSEs, delegation of board powers is not explicitly defined, leading to ambiguity about who has decisionmaking powers. In practice, most decisions are referred to the ministries.

Government intervention is facilitated by its dominance of CPSE boards and by the numerous guidelines issued by DPE. In turn, elaborate mechanisms for accountability have made boards reluctant to take decisions without consulting the ministries and have also made management reluctant to make basic operational decisions, pushing all such decisions up to the 
BOX 6.9 continued

board beyond what is common for well-governed private companies. As a result, boards spend more time on operational details than on strategy formulation and other higher-level matters.

Thus although board empowerment has made step-by-step progress in India, many CPSEs still have a long way to go on real autonomy. Various government committees on empowerment of CPSEs have recommended that big and profitable SOEs be responsible for decision making and for the control and supervision of management, as well as for human resource issues. Implementing the recommendations would make boards real decision-making bodies in which government directors could look after the interests of the government as the majority shareholder.

Source: World Bank 2010.

boundaries and ensuring accountability, it is not enough. Empowerment of SOE boards in these areas has additional requirements:

- Clear guidance should be provided on how the state as an owner makes decisions, such as approving major transactions and ensuring that the board carries out decisions without needing shareholder approval.

- Safeguards should be designed and put in place to deal with political intervention in board matters (as discussed in chapter 3 ).

- Because corruption remains a serious problem in many SOEs, proper accountability and integrity mechanisms should be established. These should require fair and responsible behavior on the part of boards toward shareholders and stakeholders. Codes of conduct and whistleblower policies should be developed and implemented by SOE boards as vital accountability mechanisms in the empowerment process, while probity and integrity should be ensured without sacrificing efficiency. Positive steps are being taken in some countries to address corruption directly. In India, for example, as of 200821 SOEs had signed integrity pacts launched by Transparency International to safeguard public procurement from corruption.

\section{Managing Conflicts of Interest}

Conflicts of interest arise when a board member's personal interests are contrary to those of the SOE. Potential conflicts can include commercial conflicts (in which a board member, a manager, or one of their relatives has an interest in a contract or transaction with the SOE, either directly or through, for example, ownership in another company) and political conflicts (in which a government representative pursues a policy goal contrary to the interests 
of the SOE). When a board member is facing a conflict of interest, the standard approach to managing that conflict is to declare that conflict to the board, abstain from voting on the matter involved, and In some cases, abstain from participating in a board discussion on that matter.

In any SOE, board members must adhere to these practices to avoid acting in their own interest rather than in the interest of the SOE. Board members also face other potential conflicts. These include using information that they acquired as a board member in their own interest to the detriment of the company or using it to trade in securities markets. Board members also need to be aware of conflicts involving other board members and managers and act objectively in such cases.

As the board's capacity and responsibility develop, the board must ensure that systems are in place to help manage and mitigate such conflicts throughout the SOE. The board should also ensure that the SOE has adequate internal controls and that effective internal and external audits are overseen by a capable audit committee (see chapter 7).

Many countries now require that SOEs have a code of ethics or conduct that applies to the board and other employees. Besides confirming the imperative for board members to act with care and loyalty, such codes usually outline how to manage conflicts of interest and what sort of behavior is considered acceptable or unacceptable. For example, India requires a code of conduct for central public sector enterprises that includes such provisions and touches on related themes such as misuse of business opportunities by board members (box 6.10).

\section{BOX 6.10 \\ Codes of Conduct for Central Public Sector Enterprises in India}

India's Department of Public Enterprises requires central public sector enterprises to have a code of conduct that addresses conflicts of interest. An enterprise can adopt the model code provided by the department or develop its own. In either case, the code must include provisions that require certain behavior in board members and other senior officers:

- To act in the best interests of, and fulfill their fiduciary obligations to, the company.

- To act honestly, fairly, ethically, and with integrity.

(box continues on next page) 
BOX6.10 continued

- To conduct themselves in a professional, courteous, and respectful manner and not take improper advantage of their position as director.

- To act in a socially responsible manner, within the applicable laws, rules and regulations, customs, and traditions of the countries in which the company operates.

- To comply with communication and other policies of the company.

- To act in good faith, responsibly, with due care, competence and diligence, withoutallowingtheirindependentjudgment tobesubordinated.

- Not to use the company's property or position for personal gain.

- Not to use any information or opportunity they receive in their capacity as directors in a manner detrimental to the company's interests.

- To act in a manner that enhances and maintains the reputation of the company.

- To disclose any personal interest that they may have in any matters that may come before the board and abstain from discussion, voting, or otherwise influencing a decision on any matter in which the concerned director has or may have such an interest.

- To abstain from discussing, voting, or otherwise influencing a decision on any matters that may come before the board in which they may have a conflict or potential conflict of interest.

- To respect the confidentiality of information relating to the affairs of the company acquired in the course of their service as directors, except when authorized or legally required to disclose such information.

- Not to use confidential information acquired in the course of their service as directors for their personal advantage or for the advantage of any other entity.

- To help create and maintain a culture of high ethical standards and commitment to compliance.

- To keep the board informed in an appropriate and timely manner of any information in the knowledge of the member related to the decision making or otherwise critical for the company.

- To treat the other members of the board and other persons connected with the company with respect, dignity, fairness, and courtesy.

Source: World Bank 2010. 
Clear policies for related-party transactions should be established for SOEs. The definition and guidelines for related parties of SOEs should include the directors, executive management, and their related interests. The guidelines should also address requests for transactions, potentially preferential or not, by government officials, members of parliament, other SOEs, and other relevant persons. If mandates are developed for SOEs, those transactions requested by government entities that fall outside the mandated business plan might also be captured as "related-party" transactions or as reportable and disclosable events.

\section{Choosing the CEO and Overseeing Management}

Appointing and retaining qualified management are vital to ensuring good SOE governance and performance-and good practice shows that this is a key function of any board. In the case of SOEs, however, in many if not most countries the government retains the power to appoint and remove the CEO. In a recent survey of development banks, for example, in all 90 institutions surveyed the government retains the power to appoint and remove the CEO (de Luna Martinez and Vicente 2012). Such authority creates two fundamental problems: (1) it takes away a board's most important power and dilutes its responsibilities; and (2) it limits the accountability of the CEO to the board, while making the CEO beholden to the appointing line minister or ownership entity. In some countries, the government also selects senior managers. This practice too carries significant risk, as it weakens both the board and the CEO and greatly expands opportunities for day-to-day interference.

Good practice increasingly calls for empowering the board to appoint and, subject to clear terms, remove the CEO, which reinforces the key function of the board in overseeing management and ensures that the CEO is accountable to the board rather than to the government. It also reduces the scope for government interference in operational decision making. For these reasons, some countries have made changes to explicitly strengthen the power of the board:

- OECD countries such as Australia, Germany, New Zealand, Norway, and Sweden now explicitly empower the board to choose the CEO.

- Romania and a smaller number of other emerging market economies are doing the same.

- Some countries have adopted an intermediate approach. South Africa, for example, allows the board to select the CEO subject to final approval by, or in consultation with, the ownership entity and other shareholders. 
As a board's capacity develops, it can and should drive the CEO appointment process, while the government should make its voice heard through the general assembly. To facilitate a transparent and professional process, governments should specify in laws and regulations clear qualification and experience criteria for both appointment and removal and provide guidelines for nominating and selecting the CEO, including minimum qualifications, competitive contracting, and the development of a structured and transparent selection process. Various approaches have been used for the selection process:

- In Malaysia, the boards of government-linked companies have a nomination committee with independent board members to lead the vetting of suitable candidates.

- In Romania, the law requires that CEOs be selected based on a transparent and competitive process, and in the case of transport companies the process has been contracted out to private headhunters.

- In Serbia, the new public enterprise law calls for the creation of a special committee to select CEOs through a process of competitive tendering.

Good practice and company law in many jurisdictions also call for the CEO to choose the top management team. When this is the case, boards normally review the appointment of senior executives, their responsibilities, the terms of their appointment, and the authorities and reporting lines of the SOE's top managers.

In some two-tier board systems, the supervisory board is typically responsible for choosing the management board. A long-established practice in Germany, it is now followed in Estonia and Poland, as well. However, in some countries with two-tier boards the government picks the members of both, leading to the same potential problems as when the government selects managers in a one-tier system. In countries with highly developed SOE frameworks and for listed SOEs or those that are operating under company law, boards may follow good practice and be empowered to oversee executive pay (board remuneration is covered separately below).

SOE boards should also fulfill their role of evaluating management performance. This activity should cover the achievement of financial and operational results, as well as the success of implementing board strategy, establishing effective internal controls and risk environment, and ensuring the accuracy and integrity of financial statements.

Empowering boards and delegating greater powers can take place progressively as a board becomes more skilled, objective, and professional. 
As the progression matrix in annex 6A shows, this can be done step-by-step:

- A first step is to ensure that the board oversees key activities and that the state's role in approving or guiding important activities is clear.

- Progressively, the board should begin to oversee management, budgets, strategy, and major expenditures, and the state's policy in approving or guiding these areas should ensure that sufficient autonomy remains with the board.

- Developing essential functions such as selecting the CEO, managing conflicts of interest, and ensuring the integrity of financial reporting, internal controls and internal audit, and risk management systems is critical.

- Ultimately, the goal should for the board to have full authority and autonomy as provided in company law and practice for listed companies.

\section{Enhancing Board Professionalism}

In line with experience across a wide range of jurisdictions, enhancing board professionalism is one of the most effective ways to improve SOE governance and, in turn, SOE performance. Following are specific steps for raising the level of a board's professionalism:

- Separate the position of CEO and chair

- Achieve proper board size

- Develop formal (written) policies and procedures for board operations

- Establish specialized board committees

- Develop board evaluation and remuneration systems

- Ensure clear policies for addressing potential conflicts of interest

- Invest in board director training

\section{Separation of the Position of CEO and Board Chair}

Where one person is both CEO and board chair, the CEO typically dominates the board, undermining the board's ability to oversee the enterprise. Generally, having a separate chair increases the accountability of the CEO as well as the effectiveness and accountability of the board. ${ }^{5}$ Experience from Chile, Estonia, Malaysia, Peru, Romania, South Africa, Thailand, and many OECD countries encourages separation of these two positions.

A related problem is the practice of having a full-time chair. This chair may become a "super CEO," effectively controlling the day-to-day management of 
the company while the nominal CEO acts as a deputy. This potential pitfall is illustrated by Peru's COFIDE (Corporación Financiera de Desarrollo). The roles of board chair and CEO were separated, but COFIDE's governance reforms left the chair with functions similar to those of the general manager, effectively giving the chair operational control and undermining the benefits of separation. Improving SOE performance and achieving a true separation of oversight and operational functions means that responsibility for day-to-day management must remain with the CEO. Leading the board is the job of the chair, who should be a highly qualified, independent board member.

In some countries, the chair is a minister or other senior politician. In that case, a new set of problems arises, and objectivity of the board is reduced. As noted above, SOE boards should generally not include senior political figures, and the chair should be subject to the same criteria as those applying to other board members. Guidance in South Africa, for example, mandates that the chair be a nonexecutive director and an independent director.

\section{Board Size}

The size of an SOE board affects the quality of its deliberations and oversight. Indeed, very large boards are negatively correlated with financial performance. $^{6}$ Although increasingly rare, boards of 30 or more members are not uncommon in some countries, with the board used as a representative body to recognize the interests of key stakeholders. ${ }^{7}$ The trouble with large boards is that they tend to require time-consuming consensus building between constituencies, prevent detailed examination of complex issues, and make decision making cumbersome. They also can make it difficult to create a sense of collegiality or team spirit.

In OECD countries, the maximum size allowed for SOE boards ranges from 9 to 15 members (OECD 2005a). In Malaysia, the recommendation for government-linked companies is to have no more than 10-12 members. Large internationally prominent SOEs seem capable of functioning in this range: Singapore Airlines, the Development Bank of South Africa, and the Brazilian oil company Petrobras each have nine. A recent survey of stateowned development banks shows that, on average, the boards of 90 surveyed banks are composed of 8 members, with 22 percent of banks having more than 10 members (de Luna-Martinez and Vicente 2012).

How small can boards get before they begin to lack key skills-or before board members become excessively cozy with management? There is no clear evidence to answer this question. Statutory minimums reach as low as 
two members; but with one-third independent members and at least two independent board members to serve on the audit committee, the smallest recommended board size is six. For SOEs in developing and emerging markets, adopting a board size in a similar range-somewhere between 6 and 12 members-seems prudent. The precise size should be determined by the SOE's needs and resources.

\section{Formal Procedures for Board Operations}

SOEs often lack written procedures for managing board meetings, conflicts of interest, evaluation of directors, public disclosures, or other policy areas, or the procedures may be outdated and fallen into disuse. Developing formal procedures serves to protect both the $\mathrm{SOE}$ and the state and to promote consistency in decision making. In India, for example, each SOE is required to develop a best-practice manual for SOEs-covering board processes, procedures, and formats-with the goals of lessening the scope for poor governance, fostering progress toward meeting international standards, and reducing unethical or inappropriate actions (Reddy 2001). For similar reasons, a growing number of countries-such as Australia, France, and Spainprovide guidance for boards on how to better manage their work, including some model documents for SOEs and their boards. Fundamental documents for most SOEs include the following:

- Articles of association of the company

- Board and committee charters and procedures

- Codes of ethics

- A governance code (similar to a general SOE code as discussed in chapter 2)

Beyond those documents, the board should also seek to have a policy on related-party transactions; a whistle-blower policy; a dividend policy; additional details on board practices and procedures, especially for financial SOEs; a risk management policy; and internal control and internal audit policies. Drafting a large number of policies and procedures takes considerable work, but in most cases policies and procedures already exist. What may be required is revising and updating the documents and providing better access to them for employees and other stakeholders. For a code or policy issued by the ownership entity or another formal authority, ensuring access and providing awareness building are important steps.

All SOEs should begin by developing a checklist of what policies are present or missing, identifying those that need immediate attention, and setting deadlines for review. The process of reviewing and updating written 
procedures should be assigned to a person such as a corporate secretary or chief legal counsel, who may need the assistance of lawyers or other experts. The board should check that the written policies and procedures are adequate and properly enforced.

\section{Board Committees}

Internal committees enable boards to handle complex issues more efficiently, concentrating expertise in areas such as financial reporting, risk management, and internal controls. They provide useful and independent input to key policy decisions. Good practice indicates that the most common board committees include the audit committee, nomination committee, remuneration committee, and risk management committee, the last being especially important for financial institutions. Other board committees can include corporate governance, corporate social responsibility, and operational areas such as marketing and human resources. To maximize the objectivity and independence of the committees and of the board as a whole, good practice also suggests that the majority of members-including the chair-be independent directors. Boards should delegate functions to committees carefully, however, to ensure that the board as a whole still decides on the key issues under its responsibility. Formal terms of reference may be useful for defining the scope of each committee's work.

SOEs' use of board committees varies greatly between and within countries and tends to reflect the prevailing private sector models in their respective countries. OECD countries and countries with long experience in corporate governance-such as India, Malaysia, and South Africa-have SOEs with well-established committees. In countries with nascent governance frameworks and limited capacities, the audit committee is frequently required, but other committees may not exist. Within countries, specific board committees may be needed more frequently in large companies and in companies listed on the stock exchange than for other SOEs.

Audit committees are important for all SOEs, financial and nonfinancial (box 6.11). SOE ownership entities in countries such as Canada, France, India, Malaysia, and Thailand provide detailed guidance on the composition, responsibilities, and powers of the audit committee. In Thailand, this guidance is provided through a committee manual; in Malaysia, through the "Green Book" on improving board effectiveness; and in India, through its corporate governance guidelines for SOEs. National codes of corporate governance and listing rules for companies traded on stock exchanges frequently require an audit committee and detail its composition, powers, and responsibilities. In SOEs without board committees, good practice suggests 
BOX 6.11

\section{Establishing an Audit Committee}

An audit committee can assume ultimate responsibility for the control environment and provide a qualified, objective viewpoint on some of the most challenging issues the board may face. However, an effective audit committee requires expertise that existing SOE board members may lack. Audit committees are usually required to have at least two or three independent members who make up a majority, including the chair. All members should be familiar with financial matters, and at least one should have a relevant financial or accounting background. Ideally, most or all of these members should be from the private sector; but it may also be suitable to have one or two committee members with a financial or accounting background from the securities regulator, central bank, ministry of justice, or ministry of finance if that government body does not otherwise play an ownership or policy role in the SOE.

In some countries, such as Brazil, audit committees can include financial experts who are not members of the board. This practice is not considered ideal, since the audit committee is then more an advisory body than a subcommittee of the board, and its members do not have the same fiduciary duties as the rest of the board. A board without an audit committee should still have at least a few independent members who are qualified to carry out similar functions.

Audit committee duties vary somewhat across jurisdictions. However, good practice suggests the following core activities:

- Oversight of the internal audit function and responsibility for ensuring adequate resources and independence for this task.

- Responsibility for oversight and for ensuring the adequacy of the SOE's internal controls.

- Responsibility for ensuring that the SOE complies with financial reporting requirements and produces quality financial statements according to the policies.

- Advice on the choice of external auditor and coordination with the external auditor on the scope, fees, and findings of the audit.

- Responsibility for monitoring compliance.

(box continues on next page) 
B0X6.11 continued

Beyond these core functions, the audit committee may also be required or encouraged to take on other duties:

- Overseeing and reporting on risk or risk management (this may also be done by a risk committee or the board as a whole).

- Reporting on and ensuring compliance with rules on related-party transactions and other rules on conflicts of interest.

- Reporting on and ensuring compliance with rules on reporting possible error and wrongdoing inside the company (whistle-blowing).

- Ensuring compliance with legal and regulatory requirements more generally.

To carry out these functions, the audit committee must have sufficient authority to do the following:

- To investigate matters within its terms of reference.

- To have full access to SOE documents and the ability to question SOE employees.

- To meet with external or internal auditors without executives present.

- To obtain outside professional advice.

- To have access to internal reports on misconduct and whistle-blowers.

As with other board committees, the audit committee should meet regularly, between once a quarter and once a month, and its members should be able to devote sufficient time to preparing for and participating in meetings. The committee should also have written terms of reference.

that the first priority should be to establish an audit committee because of its importance.

The audit committee should be carefully composed and judged by the full board on its performance and role. Strengthening its capacity is also essential. Where audit committees are required, their function and ability to access accurate and comprehensive information about SOE activities and the integrity of internal controls may be weak. In many cases, the audit committee itself might view its task as perfunctory, or it might lack a proactive attitude toward its responsibility. Members may not be consistently qualified or prepared to serve on a more technically oriented committee. And SOE boards themselves may lack the technical skills and focus to adequately understand and oversee internal controls and disclosure.

Remuneration and nomination committees are increasingly commonplace in SOEs in countries with more sophisticated frameworks and in larger and listed SOEs. Their role and composition are detailed in box 6.12. 
BOX 6.12

\section{The Role and Composition of Remuneration and Nomination Committees}

\section{Remuneration Committee}

- Role. The committee considers matters relating to executive remuneration. The committee approves changes to incentive and benefits plans of senior managers, may be involved with remuneration decisions for the company as a whole, and reviews strategic human resource decisions.

- Composition. The committee is ideally composed entirely of independent directors. The CEO, chief financial officer, and head of human resources may have direct reporting relationships to the committee. The work of the committee is often supported by outside experts. It usually meets less frequently than the audit committee.

- Value. The committee adds most value when the boards are given discretion to set executive remuneration.

\section{Nomination Committee}

- Role. The committee is responsible for considering matters relating to the composition of the board, including the appointment of new directors and succession plans for the chair, other key board positions, and senior executives. The committee sometimes has corporate governance responsibilities, including conducting an annual performance evaluation of the board, its committees, and individual directors.

- Composition. The committee is ideally composed entirely of independent directors. The work of the committee is often supported by outside search or governance consultants. It usually meets less frequently than the audit committee.

- Value. The committee adds most value when boards are given discretion to nominate new members of the board and to carry out board evaluations. 
Risk management committees are also gaining importance, especially in financial institutions but also in other large SOEs, although many are still at a nascent stage (see chapter 7).

It is best to take a flexible approach with board committees based on the size and complexity of the SOE, the availability of skills, and the decisions of the board. As the progression matrix in annex 6A shows, board committees can be progressively created:

- A first step is to ensure that an audit committee is in place, with at least one independent member, to oversee internal audit and controls. Over time, the goal is to ensure that the committee is composed primarily of independent members and eventually has independent members with primary authority over internal audit.

- For smaller SOEs or in countries where capacity is lacking, the functions of other committees-such as nomination, remuneration, risk management, and corporate governance-could be carried out by the full board and then gradually delegated to committees as experience and skills are gained.

Good practice requires that committees be chaired by or composed of independent directors; the lack of such directors in countries with low capacity may mean that independence will need to be phased in over time. For example, a first step could be to create an audit committee, with at least one independent director, and progressively increase the number of such directors so that it is primarily or entirely composed of such directors over time. The activities of all committees should be disclosed in the SOE annual report (see chapter 7).

\section{Setting Board Remuneration and Evaluation}

\section{Board Remuneration}

Good practice calls for board remuneration to be competitive and set in a way that attracts, motivates, and retains qualified people and serves the interests of the company. It also calls for the board to determine the level of remuneration paid to directors. SOE board remuneration practices differ by country, by the size and complexity of SOEs, and by listing status (listed or unlisted). They also differ between executive and nonexecutive directors.

Executive Remuneration. For executive directors, salaries and benefits are generally considered adequate compensation for any board-related 
duties they may have. Such directors typically do not receive additional compensation for sitting on boards. More and more, executive remuneration is being benchmarked against the competition and linked to performance. Particular attention is being paid to the effectiveness of compensation plans in attracting and motivating CEOs and other senior executives. Remuneration is typically set by the government or by remuneration committees of the board. The approval of the government or of the general assembly is usually required to ensure the transparency of remuneration and keep it from leading to excesses.

Some countries require that executive remuneration be set within the confines of broader public sector pay policy, but it is important that the policy allows board discretion and does not limit the ability of the SOE to hire competitively. For that reason, greater flexibility is being given to SOE boards in setting remuneration, as the examples below show:

- In India, executive pay was formerly tightly defined, but now boards are permitted to have remuneration committees that set pay, including performance-based pay, within the guidelines of a more flexible SOE pay policy.

- SOE boards in Malaysia, South Africa, and Thailand also have remuneration committees with independent board members who have greater discretion to pay market rates and use performance-based pay, with shareholder approval as needed. In the case of Malaysia, the Putrajaya Committee on GLC High Performance Guidelines provides detailed guidance for executive compensation as part of its performance management guidelines (box 6.13).

- Finland has recently introduced new guidelines on the remuneration of senior executive management, based on principles of "openness" and "moderation," while providing SOEs opportunities to compete for competent executives. The guidelines assign responsibility to the board for management remuneration decisions, with deviations for specific cases, and takes into account variations among SOEs: (1) in wholly owned companies, no deviation from the guidelines is permissible without prior approval of the owner; (2) unlisted majority-owned companies must follow the guidelines unless otherwise required by the common interest of shareholders; (3) in listed majority-owned companies, the board is expected to recognize the guidelines with respect to other laws and regulations, such as the Companies Act, Securities Markets Act, and the Corporate Governance Code; and (4) in companies in which the state is a minority owner, the guidelines provide an opinion of one major shareholder on good and acceptable remuneration principles, and as 
BOX 6.13

\section{Compensation Framework for Government- Linked Corporations in Malaysia}

The government of Malaysia encourages GLCs to review the compensation required to attract and retain the right talent while ensuring that the business remains financially sustainable. As well as base pay compensation, GLCs can use cash or shares as performance bonuses to motivate senior management behavior and success in reaching the company's overarching strategy and objectives. The guidelines provide the requirements for establishing an appropriate compensation framework:

- Ensure that base pay is competitive. It should be set around the 50th percentile of peer companies, while the board can set higher levels to attract the best talent.

- Ensure that base pay increments reflect individual performance. All increments must reflect the overall rating of the individual and show true dispersion between high and low performers.

- Link bonuses and total compensation to rating. Set a minimum performance threshold measured against the key performance indicators that has to be met before employees are entitled to a performance bonus or an increment in base pay. The threshold should not be below 50 percent. There should be high variability in total compensation that is strongly linked to an employee's rating.

- Ensure that total compensation is competitive in the market. Total compensation should be commensurate with the company's performance and competition for talent; benchmarking of performance bonuses and total compensation can be carried out against domestic and international peers; the variable part of the compensation should be significant, and in this regard boards should gradually reduce company bonuses and increase the performance bonuses, and the performance bonuses should recognize the targets achieved so that total compensation may match or exceed the market average.

- Use cash rewards. Cash or a combination of cash and shares may be used to align short-term incentives; a GLC's ability to afford a cash payout must be built into the reward calculation, and the payout system needs to ensure that both short- and long-term performance be considered; performance bonuses should be self-funded. 
BOX 6.13 continued

- Use share-based rewards. When GLCs are in a position to do so, long-term incentives can be based on shares (share options, shareappreciation rights, or other forms of share-based instruments); the shares awarded should be spread over an adequate vesting period to ensure adequate links to long-term value creation and retention of key personnel (for example, five years); the option price offered should be based on the market price on the date of award without any discount.

Source: Putrajaya Committee 2006.

such boards are to take the guidelines into account in their decision making (Government Communications Department of Finland 2012).

- In Norway, new guidelines on management remuneration issued in 2011 stipulate that management salaries in companies with partial or full state ownership should be competitive but not the highest when compared with similar companies. The guidelines also stipulate that share options are not to be used in SOEs, that variable pay components such as bonuses are not to make up more than six months of fixed pay, that the level of management pensions should not exceed those of ordinary workers, and that severance pay packages should not exceed one year's salary.

Nonexecutive Remuneration. For nonexecutive directors, good practice calls for board remuneration to be competitive and set in a way that attracts, motivates, and retains qualified people and serves the interests of the company. It also calls for the board to determine the level of remuneration paid to directors.

In the case of SOEs, however, remuneration of nonexecutive directors gives rise to special issues. One issue is the remuneration of civil servants who serve as government nominees on the board. Contrary to good practice, many countries treat civil servants just as other board members in terms of fees and, in some cases, director liability. In Thailand, for example, civil servants, who are heavily represented on SOE boards, are paid the same amount as other board members in addition to their regular compensation, which can be substantial in listed companies, especially for the chair (World Bank 2012). Two potential conflicts arise with the practice of paying civil servants board fees: (1) it provides government officials with an incentive to take on more directorships, which may lead them to neglect their duties as public servants or prevent them from properly preparing for 
board meetings; and (2) it may provide a strong incentive for government officials to seek to become nominees of the companies with the highest remuneration practices rather than where they can make the most difference.

Good practice suggests that fees should not be paid to civil servants since they are performing board duties as part of their jobs. Fees compromise their duty of loyalty to the SOE (since the civil servants are beholden to ministers or others who nominate them) and can lead to the perverse incentives as discussed above. For these reasons, countries such as Lithuania and the Philippines do not pay directors' fees to civil servants. The aim is to prevent inappropriate practices and to ensure transparency, accountability, and prudence in the spending of public funds. Where fees are paid to civil servants, they should be treated like any other board members with respect to their selection, responsibilities and accountabilities, and liabilities.

Another issue is that remuneration is often set or regulated by the government rather than by the board, which is contrary to good practice. Similar to executive directors, the compensation of civil servants and other nonexecutive members-such as private sector members and independent membersis also sometimes determined by the government rather than by the board. Remuneration should ideally be determined by the board or its remuneration committee and be approved by the government or by the general assembly.

The structure and level of remuneration can also be an issue. Remuneration typically involves the following components:

- Fees per meeting or, in rarer cases, a monthly or annual cash retainer

- Fees for additional work, such as on committee assignments

- Fees for additional responsibilities, such as serving as chair of the board or of a committee

- Reimbursement for legitimate travel costs and business expenses

Board fees vary by country and within countries by the size and complexity of the SOE, by the market environment in which they participate, and by their listing status. Board fees tend to be higher in large SOEs and in listed SOES-and, in a few cases, higher for SOEs than for other listed companies. For example, a recent study reviewed the practices and compensation of nonexecutive directors in the largest listed companies, including SOEs, in Indonesia, Malaysia, Singapore, and Thailand. It resulted in several findings:

- In Indonesia, Singapore, and Thailand, nonexecutive directors in state-owned companies receive higher compensation than in other companies. 
- Indonesia has the highest total board costs (US\$1,090,000) and average nonexecutive director compensation (US\$178,600), largely because SOEs and some private companies stipulate their pay to nonexecutive directors as a percentage (40 percent and 36 percent, respectively) of the president's and director's compensation, including both salary and bonus components, which are performance linked. In comparison, most of the remuneration for nonexecutive directors in the other countries is director fees that are not performance linked.

- In all four countries, board remuneration committees are responsible for recommending remuneration packages, and the entire board determines the package (Hay Group 2012).

In general, however, SOE board remuneration tends to be below what board members might be paid by comparable companies in the private sector, making it hard to attract and retain talent. Competitive rates may be less of an issue in SOEs that are mainly concerned with delivery of policy and social goals. In major emerging market countries with a wellfunctioning private sector, and especially for those SOEs that operate in a competitive environment, the compensation of private sector boards provides a benchmark for setting remuneration. In Malaysia, for example, compensation guidance for government-linked companies calls for pay to be set at the 50th percentile of an appropriate peer group. The peer group should reflect similarities in various attributes: (1) skills, experience, and time commitment required of the board members; (2) the company's current situation (for example, if it is undergoing significant change or experiencing high growth); and (3) the company's aspirations (for example, to be in the top three in market share in the country or region) (Putrajaya Committee 2006). In other cases, such as the Arab Republic of Egypt and India, remuneration levels are often significantly below what board members might be paid by comparable companies in the private sector. While government control prevents the SOE board from overpaying itself, low compensation makes it difficult to attract those who could add the most value. It also creates incentives to hold more board meetings than are needed to obtain sitting fees and increase compensation.

Other forms of compensation such as short-term bonuses and other benefits are also available, but they need to be designed properly as they align the interests of nonexecutive directors closer to management and may encourage management to take excessive short-term risks. Performance targets also need to be carefully designed so that they are not manipulated or "gamed" to improve pay. Bonuses may also 
compromise the independence of directors. Thus, while bonuses can help attract and motivate directors, how much of a board member's pay can and should be tied to performance targets needs to be carefully considered.

Many of the above problems stem from a lack of clear board remuneration policies, and a first step should therefore be to develop a proper policy. Given the wide range of SOEs in a given country, as well as wide variations among countries themselves, it is not possible to recommend a single policy approach. Several factors will have an effect, including the prevailing laws and regulations; industry practices; existing company practices, the size and complexity of the companies; and the market environment in which they operate, among others. Nevertheless, the following principles are useful in developing board remuneration policies:

- SOEs should be grouped according to their characteristics so that fees may be comparable by SOE size and industry, given the wide differences by industry, particularly in financial and nonfinancial sectors.

- Compensation practices of private sector boards provide a benchmark, although there may be a preference for applying a "public sector discount," in recognition of the public nature of SOEs.

- Remuneration should be competitive and commensurate with the directors' responsibilities and accountabilities.

- Care must be taken to ensure that the packages are not set so high that they jeopardize the independence of directors.

- All nonexecutive board members should be paid the same amount.

- Remuneration structures should be kept simple, with both fixed and variable components. They should be structured in a way that provides incentives for taking on additional responsibilities, for example, the chairmanship of a committee.

\section{Board Evaluation}

Traditionally, SOE boards have lacked a formal process for evaluating board members, but that has begun to change. Egypt, Chile, India, Malaysia, New Zealand, South Africa, Thailand, and many if not most OECD countries now require or encourage boards to undergo regular evaluations. The aim is both to understand how members contribute to the board's tasks and to give members feedback on how to improve their performance.

Typically, the starting point is a self-evaluation of the board as a whole. As the board gains practice with the assessment, the performance of individual 
members may receive greater scrutiny. Because of the sensitivities, the results may remain confidential, although third parties could be involved in the evaluations. Evaluation of the board may also be carried out by ownership agencies, as, for example, in the case of China, where SASAC evaluates the boards of companies in its portfolio, focusing on both the standard operations of the board (such as operating mechanisms, board responsibilities, and institutional systems) and on the effective operation of the board (like the effectiveness of decision making and supervision and administration). Results of performance evaluation fall into three categories: (1) wellperforming boards that are recognized and encouraged; (2) boards in need of improvements that are given guidance and a deadline for making the needed changes; and (3) boards in need of restructuring that are required to develop and implement an improvement plan (SASAC 2011). (See annex 6C for a more detailed discussion of board evaluations and how they may be designed.)

The key items usually evaluated include board performance against its objectives, board and board committee effectiveness, board relationships, board communications with management, and board processes and procedures. Experience suggests a number of lessons for conducting board evaluations:

- Obtain commitment from the chairman to carry out the evaluation.

- Ensure board agreement for self-evaluation or external evaluation.

- Focus on a limited number of defined issues.

- Protect anonymity in questionnaires.

- Document the outcomes of the evaluation.

- Report back to the chairman and the whole board (but not individual assessments).

- Reach board agreement on an action plan and follow up on implementation.

\section{Providing Board Director Training}

A well-run and capable board is more likely to attract competent and qualified directors. Likewise, the appointment of high-caliber directors will raise the performance of the board. It is a virtuous cycle. However, board members with little or no preparation are often appointed to their positions. Too often, it is assumed that the skills and experience they bring are enough. Board members may think they do not need training, or they find it tedious or too academic. The delivery of training may not be geared to busy 
professionals who have little desire to step back into the classroom for its own sake. And many SOEs, especially smaller SOEs, may be unable to pay for training.

In reality, however, it takes time for a board member to become effective. Thus, there is a substantial payoff from investing in training, both specific training for individual roles and more general board training. ${ }^{8}$ More and more countries are undertaking training programs for directors, and many are making training mandatory-in some cases even before they are selected for the position. Experience across a range of countries suggests that training is generally one of two broad types: general board training or induction training.

\section{General Training}

General board training typically covers basic corporate governance principles and practices; business ethics; board duties, responsibilities, and liabilities; strategic thinking; communication skills and techniques; and specialized skills and tools in core areas such as legal responsibilities, risk management, internal controls, corporate reporting, and compliance. Ideally, training will include interaction with board members from other enterprises and sectors, through formal case studies as well as informally.

Training can be offered in different forms. One approach is through training courses: a growing number of countries employ specialized institutes to prepare classes and methodologies geared to board members, distinct from more academic and youth-oriented education. These institutes have built a brand-and sometimes a club-that board members want to be associated with. Ownership entities have encouraged these institutions through direct support (or support from donors) and by encouraging or requiring SOE board members to receive training. Some countries, including Malaysia and Thailand, have specific institutes for SOE board members. But in these and many other countries, SOE board members also participate in more general director training.

In markets too small to have a permanent institution, workshops can be arranged with experienced trainers from other countries, or board members from larger SOEs can go abroad. While both options can be costly, workshops, if they can be arranged, are more economical than offshore training (although offshore training might be more appealing to otherwise skeptical board members).

In another approach to training, directors are exposed to training through practice and continuous programs to master and sustain learned competencies. Learning from best practice and peers is another option. 
Communications with peers can take place through a community of practice in different forums, such as regional or international networks on corporate governance or through company circles. Such networks provide a useful platform for exposure to good practices. Board members and senior executives should attend periodic workshops, update their knowledge, and participate in continuous professional education programs. Toolkits and other resources produced by the International Finance Corporation can be helpful in developing in-house training programs; see http://www.gcgf.com.

\section{Induction Training}

Even when board members have received appropriate general or professional training, induction training helps prepare a new director for the circumstances of a particular SOE. Such training should cover several specific issues:

- The background, mission, and challenges faced by the SOE, including Industry-specific information

- The role of the board of directors

- The role, responsibilities, and powers of a director

- The role of ministers and ministries

- The role of management

- The relationship between social and commercial objectives and how to manage potential trade-offs

SOE boards should be encouraged to develop common lists of information that will benefit all new board members. The induction process should be included among the formal procedures that enhance the professionalism of the board of directors.

Induction training should focus on a basic understanding of the director's role and on how directors can make contributions early on. Serving directors consider themselves less at risk when new appointees join the board knowing their responsibilities.

The progression matrix found in annex 6A summarizes the structures and functioning of SOE boards for good corporate governance. Notwithstanding the considerable variation among countries' political and administrative culture and history, successful SOE boards share three elements: highly capable personnel with relevant expertise, clear delineation of responsibilities and authority, and transparent, rules-based procedures. This chapter has explored these three elements in some detail and has suggested potential priorities and pathways for effective reform. 


\section{ANNEX 6A IFC-World Bank Progression Matrix for State-Owned Enterprises: Structure and Functioning of the Board}

\begin{tabular}{|c|c|c|c|}
\hline $\begin{array}{l}\text { Level 1: Acceptable } \\
\text { corporate governance } \\
\text { practices }\end{array}$ & $\begin{array}{l}\text { Level 2: Extra steps to } \\
\text { ensure good corporate } \\
\text { governance }\end{array}$ & $\begin{array}{l}\text { Level 3: Major contribution } \\
\text { to improving corporate } \\
\text { governance nationally }\end{array}$ & Level 4: Leadership \\
\hline $\begin{array}{l}\text { The board includes } \\
\text { nonexecutive } \\
\text { members with } \\
\text { commercial and } \\
\text { financial experience; } \\
\text { no ministers or elected } \\
\text { officials serve on the } \\
\text { board. } \\
\text { The board oversees } \\
\text { key activities; the } \\
\text { state's role in } \\
\text { approving or guiding } \\
\text { key activities is clear. } \\
\text { Board members seek } \\
\text { to avoid conflicts and } \\
\text { declare them to the } \\
\text { board. } \\
\text { The board meets } \\
\text { regularly, and board } \\
\text { members understand } \\
\text { their tasks, duties, and } \\
\text { responsibilities. } \\
\text { Board members are } \\
\text { provided with } \\
\text { adequate and timely } \\
\text { information. } \\
\text { The board is not so } \\
\text { large as to hinder } \\
\text { effective deliberation. }\end{array}$ & $\begin{array}{l}\text { - The board includes } \\
\text { nonexecutive } \\
\text { members from the } \\
\text { private sector. } \\
\text { - The board oversees } \\
\text { management, } \\
\text { budgets, strategy, } \\
\text { major expenditures, } \\
\text { and the like; the } \\
\text { state's role in } \\
\text { approving or guiding } \\
\text { these areas leaves } \\
\text { sufficient autonomy } \\
\text { to the board. } \\
\text { - The board manages } \\
\text { potential conflicts of } \\
\text { interest; it has a code } \\
\text { of ethics or conduct. } \\
\text { - The board uses } \\
\text { written policies and } \\
\text { procedures. } \\
\text { - An audit committee is } \\
\text { in place, with at least } \\
\text { one independent } \\
\text { member. } \\
\text { - Board members' pay } \\
\text { is linked to } \\
\text { responsibilities. } \\
\text { - Board members have } \\
\text { taken some } \\
\text { leadership and } \\
\text { development training. }\end{array}$ & $\begin{array}{l}\text { - The board has a significant } \\
\text { number of formally } \\
\text { independent members. } \\
\text { - The board selects the CEO } \\
\text { and sets CEO pay. } \\
\text { - The board ensures the } \\
\text { integrity of financial } \\
\text { reporting, internal control } \\
\text { and internal audit, and risk } \\
\text { management systems. } \\
\text { - The position of chair } \\
\text { is separate from the } \\
\text { position of CEO. } \\
\text { - The audit committee } \\
\text { oversees internal audit and } \\
\text { controls and is composed } \\
\text { primarily of independent } \\
\text { members. } \\
\text { - Committees with } \\
\text { independent members } \\
\text { oversee such areas as } \\
\text { remuneration, nomination, } \\
\text { and conflicts of interest. } \\
\text { - Evaluations of the } \\
\text { board and CEO are } \\
\text { conducted. }\end{array}$ & $\begin{array}{l}\text { - The board is } \\
\text { dominated by } \\
\text { members from the } \\
\text { private sector. } \\
\text { - The board has a } \\
\text { majority of } \\
\text { independent } \\
\text { directors, including a } \\
\text { chair who is } \\
\text { independent of the } \\
\text { government. } \\
\text { - The board has full } \\
\text { authority and } \\
\text { autonomy as } \\
\text { provided in company } \\
\text { law and practice for } \\
\text { listed companies. } \\
\text { - The audit committee } \\
\text { has all independent } \\
\text { members and } \\
\text { primary authority } \\
\text { over internal audit. } \\
\text { - All board members } \\
\text { receive induction and } \\
\text { ongoing leadership } \\
\text { and development } \\
\text { training. }\end{array}$ \\
\hline
\end{tabular}


ANNEX 6B Guidelines for Centralized Management of the Board Nomination Process

Action Comments

Review each board's retirement schedule and identify directors due to retire.

Discuss retirements with individual chairs.

Review skills profile with performance monitoring analysts.

Brief shareholder on list of retirements and recommendations on reappointment or replacement.

Brief shareholders on recommended skill requirements.

Circulate the skills profiles to interested agencies.

Review database for candidates.

Assemble nominations.

Seek shareholder's approval to proceed with the selection process.

Arrange interviews with selected candidates.

Review outcome of interviews with chairs.

Present recommendations to shareholder.

Shareholder selects appointees.

Invite candidates to conduct their own due diligence.

Submit formal appointment papers to shareholder.

Appointments formally approved and appointment documents sent to appointee and to SOEs.
Six months before term ends. Boards need timely notice to prepare for director retirements.

Determine whether first-term directors merit reappointment and if second-term directors may retire without adverse effects on board performance.

Concurrently consider board skills profile.

If a board is addressing a major issue and a retiring director is key to the success of the program, consider allowing a second-term director to remain for an additional limited term.

The analysts will provide another perspective on how well the SOE is performing and whether problems are due to the board.

Vacancies and skills profiles finalized.

Confirm status with each chair to help chairs manage the intended board changes.

To avoid irrelevant nominations, it is important that these agencies understand the role of a director.

The database should be searchable by skills, experience, and location.

Review with SOE chairs to confirm that required skills have been identified.

Develop short list for in-depth evaluation.

Submit recommendations in a form that relates them to the skills profile.

In conjunction with each SOE chair.

May also consult with performance analysts.

Submit recommendations in a form that relates them to the skills profile.

Candidates are entitled to assess whether they can add value and to assess personal risks, style of board and chair, and more.

SOE chair should facilitate candidates' meetings with the CEO and others and their access to relevant company material.

This assumes that the candidates agree to serve.

Shareholder may have an obligation to confer with cabinet colleagues.

Appointees are directors as soon as they sign the appointment letters. 
ANNEX 6B continued

Action

Comments

SOE initiates induction program.

Detailed presentations on relevant company issues and on how different parts of the SOE's business are conducted.

May include inspection of facilities.

Central authority initiates sector induction program.

Directors should understand the SOE's place within government as well as government's general expectations of the SOEs.

Source: Hamilton 2011. 


\section{Annex 6C. Board Evaluation}

Evaluations are a powerful tool for sensitizing boards to the link between governance and performance. Although still uncommon, a number of countries now require or encourage boards to undergo regular evaluations. In Egypt, for example, the importance of board evaluations is confirmed in the SOE code:

6-22 Appropriate mechanisms must be instituted to evaluate the performance of the boards. . . 6-23 The board of public enterprises should prepare an annual evaluation of its achievements. This represents a strong incentive for each member in the board to devote the time and effort to carry out his membership responsibilities. (Egyptian Institute of Directors 2006)

Evaluation can be applied to the board as a whole, to committees, and to individual board members. For the board as a whole, the evaluation should be closely linked to the SOE's performance management system. For individual board members, the evaluation should recognize that being a good board member involves a mix of "hard" and "soft" skills.

The question of how to carry out a board evaluation is a sensitive and challenging one. Few boards or board members welcome formal performance evaluations. Board members have, after all, been selected for their stature, their competence, and their probity. One approach to outlining an evaluation system is by responding to three basic questions: (1) should the assessment be internal or external? (2) should it be qualitative or quantitative? (3) should it be a self-assessment or a peer assessment? Annex 6C summarizes advantages and disadvantages of the different approaches.

Since no board of directors wants to run the risk of embarrassment, an internal, qualitative self-assessment could be a good place to start. It may also be quite cost effective. Self-assessments have evident limitations, however. External assessors can play a role not only in analyzing the governance of the SOE but also in educating directors, catalyzing a reform process, and drafting an action plan. Some companies use a combination of self-assessment and external assessment.

Once an SOE board has decided to undertake an assessment and selected an approach, practical recommendations to initiate the process include the following:

- Start with the full support of the board chair and the ownership entity.

- Do not blame and shame.

- Underscore that the objective is to improve the performance of the SOE. 
ANNEX 6C Advantages and Disadvantages of Different Approaches to Board Evaluation

\begin{tabular}{|c|c|c|}
\hline Feature & Advantages & Disadvantages \\
\hline \multicolumn{3}{|l|}{ Internal or external assessment? } \\
\hline \multirow{2}{*}{$\begin{array}{l}\text { Internal. An assessment of the performance } \\
\text { of an organization (or its individual } \\
\text { members) carried out by individuals within } \\
\text { and connected to the organization being } \\
\text { assessed. }\end{array}$} & $\begin{array}{l}\text { More knowledge about } \\
\text { corporation, board }\end{array}$ & $\begin{array}{l}\text { Often limited assessment } \\
\text { experience }\end{array}$ \\
\hline & $\begin{array}{l}\text { Less costly than engaging } \\
\text { external assessor }\end{array}$ & $\begin{array}{l}\text { May be less objective than } \\
\text { external assessment }\end{array}$ \\
\hline \multirow{2}{*}{$\begin{array}{l}\text { External. An assessment of the performance } \\
\text { of an organization (or its individual members) } \\
\text { carried out by experts who are not connected } \\
\text { to the organization being assessed. }\end{array}$} & $\begin{array}{l}\text { More objective assessment } \\
\text { Advanced assessment }\end{array}$ & $\begin{array}{l}\text { Less knowledge about } \\
\text { corporation, board }\end{array}$ \\
\hline & & More expensive \\
\hline \multicolumn{3}{|l|}{ Qualitative or quantitative assessment? } \\
\hline \multirow{2}{*}{$\begin{array}{l}\text { Qualitative. An analysis of subjective } \\
\text { measures that do not lend themselves to } \\
\text { quantitative, numerical measurement. } \\
\text { Qualitative assessment is generally in } \\
\text { narrative form. }\end{array}$} & $\begin{array}{l}\text { May provide richer, deeper } \\
\text { answers }\end{array}$ & $\begin{array}{l}\text { Time consuming to complete } \\
\text { well }\end{array}$ \\
\hline & & Harder to compile results \\
\hline \multirow{3}{*}{$\begin{array}{l}\text { Quantitative. The use of numerical and } \\
\text { statistical techniques rather than analysis of } \\
\text { subjective measures of behavior. Quantitative } \\
\text { measurement is generally used to obtain } \\
\text { responses in a numerical form. }\end{array}$} & Quick to complete & Less depth to answers \\
\hline & Easy to compile answers & May miss in \\
\hline & Standardized questions & $\begin{array}{l}\text { information not captured by } \\
\text { questions }\end{array}$ \\
\hline \multicolumn{3}{|l|}{ Self-assessment or peer assessment? } \\
\hline $\begin{array}{l}\text { Self-assessment. A process of critically } \\
\text { reviewing the quality of one's own } \\
\text { performance; examining one's own work in } \\
\text { a reflective manner to identify strengths } \\
\text { and weaknesses. }\end{array}$ & $\begin{array}{l}\text { Enables individual directors to } \\
\text { reexamine board or individual } \\
\text { performance, mandate, roles, } \\
\text { responsibilities, etc. }\end{array}$ & $\begin{array}{l}\text { Offers only one perspective } \\
\text { Individual reporting bias }\end{array}$ \\
\hline \multirow{2}{*}{$\begin{array}{l}\text { Peer assessment. A process in which } \\
\text { individuals provide feedback on the amount, } \\
\text { quality, or success of the performance of } \\
\text { peers of similar status. }\end{array}$} & Chance to assess peers & Discomfort of assessing peers \\
\hline & Multiple viewpoints & $\begin{array}{l}\text { Newer board members may } \\
\text { lack information on peers and } \\
\text { their roles }\end{array}$ \\
\hline
\end{tabular}

Source: New Zealand, Treasury Board Secretariat 2008.

- Assign responsibility to an individual (internal or external expert) to manage the evaluation process.

- Agree on relevant criteria for the evaluation and ensure that all board members are informed of the criteria.

All board members should be interviewed to find out whether they have experienced governance problems that they believe have affected the performance of the SOE. Any problems uncovered should be clearly described 
and alternative solutions discussed. All results of this assessment should then be reported to the full board to develop an action plan with areas for improvement. Remedial actions might include reconstituting committees or revising their terms of reference, providing relevant training, recruiting new board members to address noted skill gaps, and, when necessary, considering changes to the present membership of the board. Progress against the plan should be measured at least annually.

\section{Notes}

1. A large literature explores the benefits that independent board members can bring to a company. These include studies focused on emerging markets (although these, like most of this literature, focus mainly on listed companies). Benefits include a lower cost of capital, higher return on assets, reduced losses to related-party transactions, and reduced likelihood of fraud. See Claessens and Yurtoglu (2012) for summary findings and a list of studies.

2. A leading role for line ministries can also make directors beholden to the nominating ministry rather than to the company.

3. In the remaining companies, China's Organization Department of the Party Committee appoints board members.

4. These may include board nomination and performance monitoring, and oversight of budgets and SOE financing.

5. In Poland and other countries with two-tier boards, the positions are generally separated, although there can still be problems in practice.

6. There is a sizable literature on the negative correlation between board size and performance. See, for example, Hermalin and Weisbach (2003).

7. Large boards still appear in some countries, a result of requirements to have a mix of government or stakeholder representatives together with independent or executive board members. SOE boards in France must still comprise one-third employee representatives, one-third government representatives, and one-third independent members. But even in France the average size has been reduced from 30 to 18.

8. In many countries, the requirements for listed companies indicate that training is an important part of being an effective board member. India, Indonesia, Malaysia, South Africa, Thailand, and many OECD countries increasingly require or encourage training for SOE board members.

\section{References}

Bing, Li. 2011. "Performance Assessment of the Board.” PowerPoint presentation presented at the Sixth Meeting of the Asia Network on Corporate Governance of State-Owned Enterprises, Seoul, Korea, May 18. http://www.oecd.org/daf/ca /corporategovernanceofstate-ownedenterprises/48062494.pdf.

Claessens, Stijn, and Burcin Yurtoglu. 2012. "Corporate Governance and Development: An Update.” Global Corporate Governance Forum Focus 10 (rev.). 
IFC: Washington, DC. http://www.ifc.org/wps/wcm/connect/518e9e804a70d9 ed942ad6e6e3180238/Focus10_CG\%26Development.pdf?MOD=AJPERES.

COMU (Crown Ownership Monitoring Unit). 2008. Assessing Board Effectiveness: Crown Corporation Guidance. Wellington: Governance Directorate, Treasury Board Secretariat.

—. 2010. "Appointment Process." Government of New Zealand. http://www .comu.govt.nz/board-appointments/process/.

de Luna-Martinez, Jose, and Carlos Leonardo Vicente. 2012. "Global Survey of Development Banks.” Policy Research Working Paper 5969, World Bank, Washington, DC.

Egyptian Institute of Directors. 2006. The Code of Corporate Governance for the Public Enterprise Sector: Arab Republic of Egypt. Cairo: Egyptian Institute of Directors.

Government Communications Department of Finland. 2012. "A New Statement on Management Remuneration in State-Owned Companies; Remuneration to Be Based on Openness, Moderation, and Performance.” News release, August 13.

Hamilton, Ron. 2011. "The Importance of Strengthening Governance in StateOwned Enterprises.” Unpublished document. World Bank, Washington, DC.

Hamilton, Ron, and Alexander Berg. 2008. "Corporate Governance of SOEs in Zambia." Unpublished manuscript. World Bank, Washington, DC.

Hay Group. 2012. "Non-Executive Directors in ASEAN: Pay Practices, Responsibilities, and Practices." February. http://www.haygroup.com /Downloads/my/misc/ASEAN_NED_report_final.pdf.

Hermalin, Benjamin E., and Michael S. Weisbach. 2003. "Boards of Directors as an Endogenously Determined Institution: A Survey of the Economic Literature." Economic Policy Review 9 (1): 7-26.

IFC (International Finance Corporation). 2012. "IFC Corporate Governance Methodology." IFC, Washington, DC. http://wwwl.ifc.org/wps/wcm/connect /topics_ext_content/ifc_external_corporate_site/corporate+governance /investments/methodology.

OECD (Organisation for Economic Co-operation and Development). 2004. OECD Principles of Corporate Governance. Paris: OECD.

OECD 2005. OECD Guidelines on Corporate Governance of State-Owned Enterprises. Paris, OECD.

OECD 2011. State-Owned Enterprise Governance Reform: An Inventory of Recent Change. Paris, OECD.

- 2013. Board of Directors of State-Owned Enterprises: An Overview of National Practices." Paris: OECD.

Putrajaya Committee. 2006. The Green Book: Enhancing Board Effectiveness. Kuala Lumpur: Putrajaya Committee on GLC High Performance.

Reddy, Y. R. K. 2001. "The First Principles of Corporate Governance in Public Enterprises in India: The Yaga Report.” Standing Conference on Public Enterprises and Yaga Consulting. http://www.academyofcg.org/firstprinciples .htm. 
Rudolph, Heinz P. 2009. "State Financial Institutions: Mandates, Governance and Beyond.” Policy Research Working Paper 5141. World Bank, Washington, DC.

World Bank. 2010. "Corporate Governance of Central Public Sector Enterprises: Republic of India.” Finance and Private Sector Development Vice Presidency, World Bank, Washington, DC.

.2012. "The 2012 Corporate Governance ROSC for Thailand." World Bank, Washington, DC. 



\section{CHAPTER 7}

\section{Transparency, Disclosure, and Controls}

Transparency and disclosure are vital to holding state-owned enterprises (SOEs) accountable for their performance. An effective reporting regime requires SOEs to abide by the same reporting, control, and audit frameworks as other significant corporate or public interest entities; to produce financial statements according to high-quality accounting standards; to increase the effectiveness of nonfinancial reporting; and to disclose publicly both financial and nonfinancial information. A sound control environment captures and transmits relevant information in a timely and reliable manner and protects the integrity and efficiency of the SOE's governance and operations, while a qualified independent external audit is one of the major ways to increase the reliability and credibility of SOE reporting.

This chapter describes four main components of an effective regime for SOE transparency and disclosure:

- Guiding principles on transparency and disclosure

- Improving the reporting and disclosure of financial and nonfinancial information 
- Strengthening the control environment

- Undertaking independent external audits.

Annex 7A provides a summary matrix for diagnosing the transparency, disclosure, and control practices of an SOE and for identifying practical, progressive steps for improvement. The matrix covers the main elements of transparency, disclosure, and controls, as set out in this chapter.

\section{Key Concepts and Definitions}

Disclosure refers to the release of financial and nonfinancial information on the state of affairs of an SOE. Disclosures can be made to the general publicthrough the public release of financial statements or annual reports, for instance-or to select groups such as ownership entities, other shareholders, or debt holders. Laws, regulations, or government policies usually mandate the release of a minimum amount of information.

Financial reporting standards refer to the rules stipulating that a company's financial accounts be prepared in a consistent and comparable manner (both across companies and across reporting periods). The financial reporting standards vary widely from jurisdiction to jurisdiction. SOEs sometimes have to comply with the same financial reporting standards as private sector listed companies. International Financial Reporting Standards (IFRS) have been designed as a common standard, and jurisdictions are increasingly applying them to both SOEs and private listed companies. Where IFRS is not adopted, an alternative is requiring that the national reporting standards for listed companies also apply to SOEs. Finally, in some jurisdictions, the specific reporting requirements for SOEs are unique to government entities.

Nonfinancial disclosure refers to qualitative information that SOEs release about their operations. Two broad categories of nonfinancial information are often disclosed: information about an SOE's structure and governance and information on its operational performance. The first category consists of matters such as the ownership and voting structure of the SOE and the remuneration of key executives. The second category includes matters such as quality-of-service measures and safety performance. Notwithstanding their qualitative nature, nonfinancial disclosures can be mandatory (for instance, as part of annual reporting requirements), but generally these more expansive public disclosures are part of a voluntary or shareholder-led regime for greater transparency.

The control environment refers to the structures that SOEs establish to ensure, first, that the financial and nonfinancial reporting regimes 
adequately capture all relevant information; second, that this information is transmitted to the relevant users in an accurate and timely manner; and, third, that processes are in place to enable effective responses. It includes internal control systems, internal audit functions, risk management systems, and compliance functions.

Public interest entities are generally all companies listed on a public stock market together with-depending on the jurisdiction-other economic entities whose economic significance calls for a high degree of transparency and disclosure. In the European Union, for example, all banks and insurance companies, even if they are not listed on a public stock market, are considered public interest entities.

\section{Guiding Principles}

Every SOE operates within a specific country and business environment, and any effort to strengthen its governance should be tailored to those circumstances. Nevertheless, several broad principles of SOE transparency, disclosure, and control arrangements can be used to guide improvements.

\section{Use of Standard Reporting Requirements}

Timely, accurate, and appropriately audited financial statements are one of the most important tools for holding the management of an enterprise accountable for its stewardship of the company. Clearly, the state as owner of the SOE has a compelling interest in monitoring the SOE's performance. Moreover, the general public has an interest in SOE performance, both because citizens are concerned about how publicly owned assets like SOEs that are funded by taxpayer money are managed and because the activities of many SOEs have a broad impact on the wider economy and social policy.

These considerations imply that SOEs should be subject to reporting requirements at least as rigorous as those imposed on privately owned public interest entities. In most cases, these private entities are required to make their financial statements available to the general public, suggesting that SOE financial statements and reports should be widely publicly available as well. For instance, in the European Union all companies with limited liability are required to file their annual financial statements with a central registry accessible to the public for a modest fee or free of charge.

If the reporting framework for private sector public interest entities is seriously flawed, then the benefits of applying it to SOEs will be limited. 
However, in most cases, the appropriate policy response in this situation is to reform the overall corporate financial reporting framework rather than attempt to construct a new framework tailored to SOEs. The World Bank's reports on the observations of standards and codes in accounting and auditing provide a wealth of information on how to improve both legal frameworks and institutional capacity in corporate financial reporting. (Detailed discussion of steps for improving these reporting frameworks, however, is beyond the scope of this toolkit.)

Although the transparency and disclosure requirements for SOEs should ideally be the same as those for privately owned public interest entities, the particular role of the state in an SOE can add complexity to the reporting and control environment. As discussed in the rest of the chapter, the most common issues that emerge are the following:

- Compared to private shareholders in public interest entities, the state may play a more active role in selecting and dismissing auditors; in dealing with auditors through audit committees or boards (where audit committees do not exist); in setting accounting, control, and risk management policies; and in reviewing the SOE's financials and reports.

- National legislation or tradition may assign an SOE auditing role to the body responsible for auditing the wider government sector (commonly referred to as the supreme audit institution, or SAI).

- The SOE may be subject to special rules (for example, on procurement or employment) imposed on the public sector but not on privately owned businesses.

- The SOE may be subject to particular public service obligations (such as a requirement to provide services to the whole population or limits on the prices they can charge to particular consumers).

\section{Role of International Standards}

High-quality international standards for most areas of transparency and disclosure have been adopted by many countries (table 7.1). Countries may choose to apply their own tailor-made standards, which, in principle, better reflect local needs than international standards do. However, significant costs can be associated with drawing up national standards, in updating them in response to changes in the business environment, and in educating those responsible for implementing and using them. Adopting international standards avoids having to "reinvent the wheel" and reduces or avoids many of those costs entirely. It also prevents lack of local capacity from leading to lower-quality national standards. 
TABLE 7.1 Main International Standards on Transparency, Disclosure, and Controls

\begin{tabular}{|c|c|c|}
\hline Topic & International standard & Standard setter \\
\hline Financial reporting & $\begin{array}{l}\text { International Financial Reporting } \\
\text { Standards; IFRS for SMEs }\end{array}$ & $\begin{array}{l}\text { International Accounting Standards } \\
\text { Board }\end{array}$ \\
\hline Internal audit & $\begin{array}{l}\text { International Standards for the } \\
\text { Professional Practice of Internal Auditing }\end{array}$ & Institute of Internal Auditors \\
\hline $\begin{array}{l}\text { Internal control and risk } \\
\text { management }\end{array}$ & $\begin{array}{l}\text { COSO Internal Control-Integrated } \\
\text { Framework }\end{array}$ & $\begin{array}{l}\text { Committee of Sponsoring Organizations } \\
\text { of the Treadway Commission }\end{array}$ \\
\hline \multirow[t]{2}{*}{ External audit } & International Standards on Auditing & $\begin{array}{l}\text { International Auditing and Assurance } \\
\text { Standards Board }\end{array}$ \\
\hline & $\begin{array}{l}\text { International Standards for Supreme } \\
\text { Audit Institutions }\end{array}$ & $\begin{array}{l}\text { International Organization of Supreme } \\
\text { Audit Institutions }\end{array}$ \\
\hline Corporate governance & $\begin{array}{l}\text { Principles of Corporate Governance; } \\
\text { SOE Corporate Governance Guidelines }\end{array}$ & OECD \\
\hline Integrated reporting & Sustainability Reporting Guidelines & Global Reporting Initiative \\
\hline
\end{tabular}

\section{Listing of SOEs on the Stock Exchange}

Adopting good reporting and corporate governance principles is not easy. Threatened by the greater emphasis on performance that increased transparency brings, Incumbent interests may resist them. Good reporting and corporate governance also require significant institutional capacity and resources. As a result, well-meaning declarations may not be translated into real action but remain as mere intentions to apply good governance principles to SOEs.

When a country considers it appropriate and has met a number of preconditions on the maturity of the financial markets and its regulatory framework, listing SOEs on the stock exchange can help overcome these obstacles and embed good corporate governance, including strong reporting and internal control practices. Even when the state remains the dominant shareholder, listing can be a way to sustain that commitment to good governance and financial reporting. To receive its listing, though, the SOE will need to meet a number of requirements based on the regulatory framework for capital markets. Public listing usually requires the regular production of externally audited financial reports and their public dissemination, as well as the adoption of shared standards of corporate governance. Examples of SOE listings are provided in box 7.1. 
BOX 7.1

\section{Stock Market Listing Can Lead to Increased Transparency}

The municipality of São Paolo is the majority owner of Sabesp, which supplies water and sewerage services to over 20 million consumers. To raise additional capital for infrastructure investment to improve the quality of its water supply and to reduce high leakage rates, Sabesp floated minority stakes on stock markets in Brazil and New York. In addition to raising funds for investment, Sabesp had to meet the requirements of a stock market listing, including improving its financial reporting and corporate governance arrangements and thus increasing its transparency and making its management more accountable for its performance.

Colombia's state-owned transmission company Interconexion Electrica S.A., which operates electricity transmission networks in Colombia and several other countries in Central and South America, is majority owned by the Colombian state. A minority stake in the company was sold through the government's "shareholdings for all" initiative, and the company has been listed on the Colombian Stock Exchange since 2001. Following the decision to list the company and then to list American depository receipts ${ }^{a}$ on U.S. stock markets, the company has significantly improved the quality of its financial reporting. Sabesp adopted a good governance code in 2001, setting out its principles of corporate governance, and produces an annual report on corporate social responsibility in addition to its annual financial report.

a. American depository receipts are a negotiable security denominated in dollars that trades in the U.S. financial markets and represents the securities of a non-U.S. company.

\section{Improving SOE Reporting and Disclosure}

Achieving adequate transparency for SOEs presents challenges that often go beyond those faced by their private sector counterparts. Although SOEs are by definition publicly owned, they may not have listed securities and thus may not be legally required to disclose information to the public. SOEs may also lack the capacity to prepare or present information properly. Disclosure on the SOE sector as a whole or on key parts of it may be nonexistent or limited. And the way the government interacts with SOEs and the mandates it imposes may not be disclosed. 
The effectiveness of financial and nonfinancial reporting can be measured across a number of different dimensions, including completeness, accuracy, timeliness, and relevance. Currently, some SOEs do not produce any public reports. Many SOEs produce reports that are incomplete (lacking key statements or notes that would normally be produced by listed companies) and inaccurate (especially in the treatment of more technical or sensitive areas) or that are so delayed that they lose their practical relevance. Because disclosure of nonfinancial information is typically underdeveloped, little if any meaningful information is disclosed.

Even when SOEs produce financial statements, they may not publicly disclose other critical information. Often they do not report their objectives or mandate, their social or policy commitments, any special power or rights the government enjoys as owner, who their board members are, their relationships with other SOEs, the risks they face, or how they are managed.

The guidelines of the Organisation for Economic Co-operation and Development (OECD) suggest that in addition to disclosing financial information, SOEs should also publicly report nonfinancial information (box 7.2).

\section{BOX 7.2}

\section{OECD Guidelines on Disclosure}

The corporate governance framework should stipulate timely and accurate disclosure on all material matters, including the company's financial situation, performance, ownership, and governance. Disclosure should include, but not be limited to, material information on the following:

- The financial and operating results of the company

- Company objectives

- Major share ownership and voting rights

- Remuneration policy for members of the board and key executives and information about board members, including their qualifications, the selection process, other company directorships, and whether the board regards them as independent

- Related-party transactions

- Foreseeable risk factors and measures taken to manage them

- Issues regarding employees and other stakeholders

- Governance structures and policies, in particular, the content of any corporate governance code or policy and the process by which it is implemented

(box continues on next page) 
BOX7.2 continued

\section{From OECD Guidelines on Disclosure}

State-owned enterprises should disclose material information on all matters described in the OECD's Principles of Corporate Governance, focusing on areas of significant concern for the state as owner and the general public, namely:

- A clear statement to the public of the company's objectives and their fulfillment

- The ownership and voting structure of the company

- Any material risk factors and measures taken to manage such risks

- Any financial assistance, including guarantees, received from the state and commitments made on behalf of the SOE

- Any material transactions with related entities

Source: OECD 2004, 2005.

Such disclosure, often more qualitative in nature, can offer stakeholders key insights into the workings of the SOE and its prospects, as well as its relationship with the state. In many cases, disclosing such information is not costly or technical, although there are some exceptions. ${ }^{1}$ The main barrier is often a lack of consensus and unwillingness to disclose, a reluctance frequently shared by the SOE management and the owner.

Many countries have significant room for improvement in SOE reporting and disclosure. A recent study of state-owned development banks indicates that 96 percent of those surveyed prepare and publish their annual reports, most of which are on their websites, and that 93 percent also disclose their audited financial statements. But the same study shows that only 71 percent of the banks disclose off-balance-sheet items, only 63 percent disclose their governance and risk management framework, and only 64 percent disclose their regulatory capital and capital adequacy ratio (de Luna Martinez and Vicente 2012). Improving SOE reporting means reforming the standards and quality of financial reporting and increasing nonfinancial reporting.

\section{Financial Reporting}

As expected of any large corporate entity, all SOEs should produce annual financial statements, including a balance sheet, cash flow statement, profit and loss statement, statement of changes to owners' equity, and notes. These 
statements should generally be finalized three to six months after the end of the financial year. They should be prepared in accordance with the accounting standards required for domestic private sector enterprises of a comparable size and complexity. ${ }^{2}$ For large SOEs in countries with welldeveloped systems for corporate financial reporting, this may mean adopting International Financial Reporting Standards. For smaller SOEs or in countries with limited financial-reporting capacity, less complex standards will be more appropriate. Good practice calls for all but the smallest SOEs having their financial statements audited. Using the same reporting standards as private sector enterprises allows SOEs to draw on an established independent body of expertise for organizing and auditing their financial statements, as well as for evaluating their significance. In contrast, using reporting standards developed specifically for SOEs can result in less transparent and noncomparable financial reports, reducing their likely impact in improving SOE performance.

A management commentary-often referred to as "management discussion and analysis"-should accompany annual financial statements. It sets out the key aspects of the SOE's performance during the reporting period and its prospects for the immediate future. This commentary can provide a more complete picture of the SOE and make it easier for the ownership entity and the wider public to evaluate its performance.

Some countries require listed companies to produce semi-annual or even quarterly financial statements. Given the costs involved, requiring quarterly reporting may be excessive, and semi-annual reporting should be a requirement only for the largest and most economically significant SOEs. It is much more important for SOEs to issue public statements summarizing the impact of changes in their own circumstances or the market environment ("material events"), whenever these are significant, even if those statements fall outside the usual reporting cycle.

A commonly observed challenge in SOE financial reporting is the need to change the overall culture of executives and staff. The staff and management of many SOEs generally come from a government background, where financial reporting may be primarily a bookkeeping exercise intended to monitor compliance with an allocated budget. The move toward a modern system of corporate financial reporting entails integrating the financial reports provided to the government and the general public with the SOE's internal systems of management reporting. This shift often requires substantial investment in new information technology systems and in staff retraining and recruitment. In the absence of such investment, preparation of the financial reports may fall to the external auditor, creating a potential conflict of interest, undermining the entire purpose of the external audit, and 
limiting the ability of the SOE's management to use the information to improve the performance of the enterprise.

Ensuring public access to the information that SOEs produce is vital. Often, a lack of consensus or considerable resistance within SOEs and in their ownership entities prevents financial and nonfinancial information on the performance of SOEs from being widely available. However, unless this information is easily accessible (through the SOE's website, for instance), the positive impact from efforts to improve the quality of SOE disclosure will be reduced. Besides making this information available on their own websites, SOEs should also provide it through other channels, including the company registrar (when corporatized) and the stock exchange and securities regulator (when listed). The ownership entity or coordinating body for SOEs should also offer relevant information for each SOE on its website.

SOEs often engage in substantial business with the government, other SOEs, or entities to which the government or other SOEs may be linked. Transactions between private sector entities with a common owner or large shareholders are treated as "related-party transactions" and are usually required to be disclosed to "draw attention to the possibility that the financial position may have been affected" by the transactions (in the words of International Accounting Standard, or IAS, 24). As of November 2009, the main international standard for disclosure of such transactions, IAS 24, does not require all transactions between SOEs or between SOEs and the government to be treated as related-party transactions (this is for jurisdictions with large numbers of SOEs, where many such transactions may be a normal part of business). But IAS 24 does require disclosure on such transactions if they are individually or collectively significant or made on nonmarket terms and are of material significance. In addition, ex ante controls over such transactions could be imposed. Such controls would be an aspect of the controlling environment, rather than the disclosure regime.

Many OECD and non-OECD countries publish an aggregate annual report on SOEs, including the consolidated income statements and balance sheets of all SOEs for parliamentary sessions. Countries with a centralized ownership function such as Chile and India are more easily able to compile and publish aggregate reports with greater depth and consistency on their website. In countries with a more decentralized ownership system, ownership ministries may report individually to the ministry of finance, which then compiles an aggregate document. Annual reports, together with quarterly reports, allow the parliament and the public to evaluate recent developments in SOEs in an efficient and transparent manner, which in turn enhances the management quality of the government (World Bank 2008). 


\section{Nonfinancial Reporting}

Many SOEs have made significant improvements in their nonfinancial reporting. Some countries-such as India and South Africa, as well as Chile, the Republic of Korea, Sweden, and other OECD countries-have SOE guidelines or requirements for disclosure that align with those for listed companies. And many large SOEs have released information on their own initiative. Still, many SOEs may not disclose some key nonfinancial information, such as related-party transactions, the company's noncommercial objectives and policy commitments, ownership and governance structures, and risk exposure and risk management.

Company Objectives and Social and Policy Obligations. Noncommercial objectives often form an important part of the rationale for the existence of SOEs. These objectives may be tied to noncommercial obligations and their associated activities that may have large repercussions for an individual SOE's performance and viability and even for the longer-term fiscal position of the government. When SOEs have noncommercial objectives, they should be well defined and explicitly presented to the public, whether in the SOE's articles or statutes, in performance management documents, or elsewhere. SOEs with social objectives should disclose the following:

- Any social commitments made

- Social outcomes

- Costs of providing social services

- Subsidies or financial assistance provided by the government or other SOEs

- Any other material engagement into which the enterprise enters as a result of its status as an SOE

Ownership and Corporate Governance Structure. For SOEs wholly owned by the government, ownership structure and rights are not a significant issue. However, for partially privatized SOEs, public disclosure of any residual control rights retained by the government beyond its share ownership is important. Sometimes called "golden shares," these control rights give the government power to block certain transactions or activities of the company beyond what its ownership or normal regulatory powers would allow. Similarly, if an SOE has both another strategic shareholder and small shareholders (a situation not unusual in partially privatized SOEs) and the state and the other substantial shareholder have a shareholder agreement, the terms of that agreement should also be disclosed. 
Each SOE should issue a public corporate governance statement that sets out its governance structure, including board committees, and relevant policies. This statement can include making such instruments as company articles and bylaws available directly and also, when required, through a company registrar or similar body. Many countries require listed companies to make a statement noting their compliance with the national code of corporate governance. South Africa, for example, also requires SOEs to disclose their compliance with the national code. India and Peru require them to note their compliance with the code for SOEs. Many countries have no such requirements for unlisted SOEs, but those SOEs should still strive to issue a governance statement noting their compliance with areas of good practice such as board independence, functions of the audit committee, and disclosure.

Like private sector companies, good practice for SOEs includes disclosure of aggregate and individual pay to board members and the CEO and the policy on which this pay is based. Board members' background, current employment, other directorships, and board and committee attendance should also be disclosed. Beyond this, the information disclosed should make it clear which board members are serving as government officials, which are primarily from the SOE or public sector, and which are from the private sector and thus bring relevant private commercial experience to the enterprise.

Risk Exposure and Risk Management. In many jurisdictions, listed companies must include a qualitative statement in their annual report discussing the potential challenges or risks they face. Financial institutions and other companies that face significant risks related to credit, liquidity, exposure to interest rate or exchange rate movements, or derivatives or other financial instruments may have to provide more detailed information. IFRS 7 (Financial Instruments: Disclosures) requires detailed quantitative disclosure of these risks, as well as disclosure of policies and processes for managing them. The Basel Committee on Banking Supervision has adopted similar requirements in its guidelines, and central banks have begun to incorporate these rules into their regulations for financial institutions.

IFRS 7 is likely to be too complex for most SOEs, but these companies should, whenever feasible, provide some indication of the major risks they face. State-owned financial institutions and larger and more complex SOEs should aim for significant disclosure in this area.

\section{Aggregate Reporting}

Good practice emphasizes aggregate reporting for the SOE sector as a whole. Such reporting provides a comprehensive picture of the performance of 
SOEs. In addition to informing the public, the process of developing aggregate reports helps improve company reporting systems, ensure consistency in information, clarify policies, and build consensus on sensitive issues. Putting aggregate information in the public domain helps the ownership entity communicate its activities and, more important, push for reforms. A number of countries are providing comprehensive aggregate reports, including India, South Africa, and Turkey.

\section{Integrated Reporting}

Some SOEs also prepare reports on corporate social responsibility, which may include the SOE's impact on different stakeholders. (Reporting on corporate social responsibility is not necessarily the same as reporting policy objectives.) For both explicit objectives and more general impact, approaches such as the balanced scorecard ${ }^{3}$ can be useful, while standards promulgated by the Global Reporting Initiative also can serve as a conceptual basis for better reporting.

Larger SOEs may consider producing "integrated reports." These aim to bring together discussion of an enterprise's financial performance with other aspects of its operations and to take explicit account of the broader social, environmental, and economic context within which the company operates. Earlier, companies often produced a variety of annual reports tailored to different audiences and bearing little relation to each other. Integrated reporting, however, presents a single picture of an enterprise's performance, which the company's stakeholders can use to hold its management to account. Integrated reporting may be particularly relevant for SOEs that have a significant environmental impact, such as those in the energy or mining sectors. This area is new, and many of the principles shaping integrated reports are still a work in progress; already, though, there are some interesting practical examples of how integrated reporting is used (box 7.3).

To reinforce the effective implementation of the disclosure framework, ownership entities should develop a specific disclosure policy for SOEs, in consultation with SOEs and other stakeholders. The policy would identify and define clearly what information SOEs should disclosed, how to disclose it, and the processes to put in place to ensure the appropriate quality of the information. Specific guidelines could also mandate or encourage higher disclosure standards than the ones now mandated by the legal and regulatory framework. At the same time, care should be taken to avoid unnecessary and excessive requirements that would disadvantage SOEs compared to private companies. Ownership entities should also proactively monitor 
BOX 7.3

\section{Integrated Reporting in Practice: The Case of ESKOM in South Africa}

ESKOM, a South African state-owned energy company, has been a pioneer in integrated reporting. For several years before 2011, ESKOM produced reports on sustainability issues accompanying its conventional financial statements. Then, in 2011-12, the company decided to modify this practice by producing a fully integrated report on its performance. The resulting report, part of the pilot program of the International Integrated Reporting Council, follows the framework set by the council and by the Integrated Reporting Committee of South Africa.

ESKOM's 2011-12 integrated report provides an in-depth review of the company's performance between April 2011 and March 2012. It outlines the company's business operations, describes the challenges the company faced during the reporting period, and provides management's assessment of the main issues facing the company in the future. The report presents the company's financial results together with its governance, sustainability, and other material factors, illustrating the interdependence between them and also between the company and its external environment. ESKOM held extensive discussions with the company's stakeholders before deciding what should be treated as "material" and thus covered in the report.

implementation and encourage compliance through guidelines, training, and incentives.

\section{Improving the Control Environment}

The systems, standards, and procedures that form a company's control environment safeguard the integrity and efficiency of its governance and operations. Every large organization needs some form of internal controls. ${ }^{4}$ Effective internal controls allow top managers to know what is going on in the organization and whether their instructions are being carried out. Management should design internal control procedures with several purposes in mind: to safeguard assets against unauthorized use or disposition, to maintain proper accounting records, and to ensure the reliability of financial information. Procedures should make certain that business processes and other activities are conducted properly, mitigate the potential for 
FIGURE 7.1 Main Actors in the Control Environment

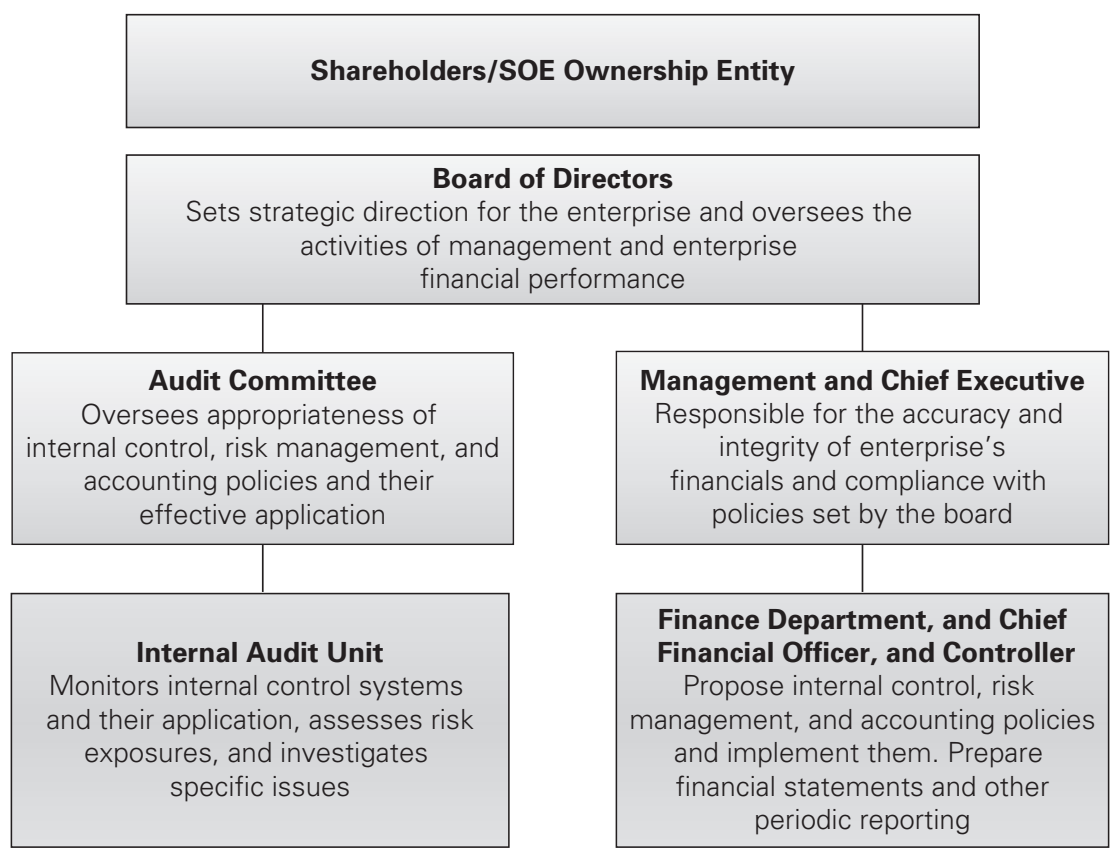

misconduct, and detect any misconduct that does occur. The main actors of the internal control environment are highlighted in figure 7.1.

In many SOEs, however, basic control systems are weak, and other vital parts of the control environment may focus so narrowly on detecting fraud that they miss the larger issue of the integrity of financial reporting and risk management as a whole. In such cases, the information disclosed to the public may be inaccurate, and SOE boards (and even top management) may have an incomplete understanding of what is happening within the organization or the risks it faces. If so, there can be greater scope for fraud and negligence.

SOEs often lack internal audit functions or have internal auditors who report to and are tightly controlled by management and thus cannot be expected to act as an independent source of information or vigilance for the board. Moreover, internal audit staff often lack the necessary qualifications or practical experience for conducting internal audits, while the information technology functions and computerization that can help facilitate the process may not be in place. Compliance functions may also be nonexistent or have yet to become effective. In the absence of a functioning internal control and audit environment, it is unclear how SOE boards and management obtain what they need to assess key issues and risks facing the SOEs. 
In some countries, the supreme audit institution, or the state auditor, may carry out these functions (as discussed below), and its representatives are often located in separate units in the companies. These units could confuse accountabilities and thus prevent any existing management or board control units (or those planned in the future) from becoming fully autonomous entities responsible to the SOE's board. Moreover, this body might not be able to conduct an effective internal audit on a commercially oriented SOE. Weaknesses in internal audits are serious, as the internal auditor is a critical source of information for the audit committee and independent board members. ${ }^{5}$ As the Institute of Internal Auditors notes, "Internal audit . . . helps an organization accomplish its objectives by bringing a systematic, disciplined approach to evaluate and improve the effectiveness of risk management, control and governance processes" (IIA 2004).

\section{Internal Controls and Risk Management}

Good practice calls for all public interest entities to have internal controls for integrity and efficiency and to link these controls with risk management systems. Malaysia, for example, provides guidance that makes this link (box 7.4). The connection between internal controls and risk management runs in both directions: good control systems provide the accurate information needed to manage risk effectively; and an understanding of the risks the company faces is important for designing effective control systems.

\section{BOX 7.4}

\section{Risk Management Guidance for Companies Linked to the Malaysian Government}

Understanding and managing risks are critical to protecting the company's value. The board has three specific roles in this regard:

- Setting the company's risk parameters. The board's role is to establish the risk parameters, thresholds, and boundaries for the company and to ensure that overall corporate risks are measured and that thresholds are controlled within predetermined limits.

- Understanding major risk exposures. The board should understand major risk exposures on an aggregate basis-that is, as far as possible, all risks are rolled into a common metric such as "cash flow at risk" or "value at risk." Furthermore, the board should ensure 
BOX7.4 continued

sufficient internal controls and clear mitigation plans for major risks, including accountabilities and timelines. For major risks, the board should also have a good sense of the costs and benefits of risk mitigation, taking into account the probability of occurrence and potential magnitude.

- Considering the risk factors in all major decisions. The board should develop a culture of identifying and managing risk throughout the organization. One way to achieve this goal is to set the right example and tone and make sure that in-depth risk analysis and quantification are conducted before the board makes all major investments or strategic decisions.

Source: Putrajaya Committee 2006.

Role of the Board in Overseeing Internal Controls. Modern corporate governance practice requires the board, either directly or through a board audit committee, to assume responsibility for reviewing the system of internal controls established by management. (The role of the audit committee is described in greater detail in chapter 6.) This oversight is important both for ensuring the effectiveness of the controls and for acting as a check on improper behavior by management. In South Africa, for example, guidance for SOEs notes that the board should ensure the "integrity of the SOE's risk management and internal controls" and that the responsibilities of "the [audit] committee should include helping the SOE and its directors to comply with obligations under the [law] and providing a forum for communication between the directors, the senior management of the SOE and the internal and external auditors of the SOE to ensure, inter alia, the adequacy of the SOE's internal controls" (South Africa Department of Public Enterprises 2002).

Good practice suggests a range of specific tasks for the board in overseeing the internal controls:

- Making sure that management puts in place functional, operating, financial, and management reporting standards across the entire company and any subsidiaries.

- Verifying that procedures are in place to identify, control, and report on such major risks as breaches of laws or regulations, unauthorized activities, and fraud. 
- Annually reviewing the effectiveness of internal controls and procedures (including financial, operational, compliance, and risk management) and reporting the findings to shareholders.

- Confirming that internal controls include procedures for identifying and reporting conflicts of interest to the board and, where appropriate, to owners.

While the first step in improving internal controls is for the SOE board to see that effective systems are in place, it is unrealistic to expect board members themselves to verify these systems. Instead, they usually rely on internal control experts and internal audit professionals to assess the quality of internal controls.

Risk Management. A central function of the SOE board is to understand the risks the enterprise faces, the possible consequences of those risks, and how to mitigate them. Since the global financial crisis that began in late 2007, risk management and risk governance have become especially important, especially for financial institutions, whether private or state owned. As with privately owned financial institutions, state-owned financial institutions may face substantial market risk from changes in asset prices, exchange rates, and interest rates; liquidity risk from a sudden demand for funds (or lack thereof); and credit risk from counterparties' failure to make payments. As a result, state-owned financial institutions are adding independent and qualified board members and a dedicated risk management function, usually overseen by a chief risk officer who reports to the risk management committee of the board. In the study of development banks referred to earlier, 88 percent of the banks indicated they had risk management units in place, but only 53 percent of these report directly to the board.

While risk management processes are increasingly well developed in private banks, in state banks they are underdeveloped, and the magnitude and nature of risk are not well defined or quantified. As a result, board evaluation of risk and related strategic decisions are difficult at best in most institutions. Many banks lack formal risk management processes as well as the human and technological resources to ensure the stature, authority, and independence of the function within the institution. Compliance functions are often in nascent stages of development.

Although many countries recognize the importance of risk management and risk governance for financial institutions, relatively few extend this concern to nonfinancial SOEs, despite the fact that these companies, particularly large SOEs, face several identifiable potential risks. Some are standard operational risks common to all businesses (such as risks from fraud, employment 
issues, business practice issues, business disruption, and the like). Meanwhile, other common risks may be external to the SOE, including possible changes in prices, exchange rates, interest rates, asset prices, market share, and other market conditions. Yet, still others are specific to SOEs and result from the behavior of the state as an owner, as when the price of a major input increases and the SOE is not permitted to pass the full cost onto consumers.

India, Malaysia, South Africa, and Thailand all have guidelines that highlight the importance of risk management for SOEs and the need for the board to engage in this function. According to the Malaysian guidelines, the board is to understand risk, set the SOE's risk appetite and limits, ensure that risk is taken into account before making major decisions, and see that internal controls and plans for handling significant risks are in place.

\section{Internal Audit}

All SOEs should have internal auditors; and to ensure their objectivity and ability to provide key information to the board, they should report directly to the audit committee (or if there is no audit committee, then directly to the board). The internal auditor may have an implicit administrative link to management, but the board, with the support of the owner, is ultimately responsible for the independent operation of the internal auditor. The internal auditor must have open access to the board to investigate any issue within the scope of the audit.

As set out in the international standards issued by the Institute of Internal Auditors, internal auditors should place particular emphasis on monitoring the SOE's control systems (box 7.5). The internal audit activity must also evaluate risk exposures related to the company's governance, operations, and information systems, including:

- Reliability and integrity of financial and operational information

- Effectiveness and efficiency of operations and programs

- Safeguarding of assets

- Compliance with laws, regulations, policies, procedures, and contracts ${ }^{6}$

The internal auditor should evaluate the effectiveness of the SOE's risk management and assess how information on risk and controls travels through the SOE. These are wide-ranging responsibilities, and the internal auditor should work with the audit committee to set priorities and develop an audit plan. This plan should take into account the internal auditor's need to be responsive when a serious conflict of interest or control failure occurs.

In addition, internal auditors should typically be able to carry out ad hoc investigations at the request of the audit committee and board. They auditor 
BOX 7.5

How São Paulo's Sabesp Used Internal Auditing to Improve the Control Environment

A comprehensive evaluation of internal controls at Sabesp provides a good example of the relationship between internal audit and internal control. The evaluation was conducted using the COSO framework ${ }^{\mathrm{a}}$ as well as the Control Objectives for Information and Related Technology, an IT governance framework and supporting tool set that allows managers to assess the company's information technology framework and to bridge the gap between control requirements, technical issues, and business risks.

The results of the evaluation led to a range of improvements. The board of directors approved a code of ethics and conduct. The company put in place whistle-blowing procedures to ensure compliance with the code of ethics, and it implemented many improvements in internal controls:

- An authority and responsibility manual disseminated on the company's Intranet established the levels of authority required for certain processes.

- New criteria were established for access to corporate information systems.

- Functions were segregated to prevent an employee from both soliciting and approving payment for the same transaction.

- Improvements in information technology led to new governance standards and strengthened control practices for all activities in the information technology environment.

- The methodology for developing corporate information systems was adjusted to the changes at the company, and the stages of systems development and maintenance were documented.

- Accounting criteria were formalized and submitted to the executive board and the audit committee for review.

- The system for reconciling accounts was revised to strengthen adherence to established criteria.

Source: World Bank Staff.

a. $\mathrm{COSO}=$ The Committee of Sponsoring Organizations of the Treadway Commission.

should have the power to see that problems noted in investigations are being addressed, and the board and audit committee should ensure that the internal auditor has the resources to carry out all tasks.

Some smaller SOEs may find it most efficient to outsource the internal audit function, although this does not reduce the need for careful oversight 
by the board. Others, including large SOEs and financial SOEs, should have a lead internal auditor and audit staff with the qualifications, numbers, and skills to carry out all needed audit functions and to consult on accounting, financial, and operational matters inside the SOE.

The main challenge in this area is likely to be finding suitable staff. For example, it may often be difficult to find enough qualified internal auditors knowledgeable about the latest developments in the field. When qualified internal auditors are in short supply, capacity building and training are essential and may require significant resources. Similarly, finding board members for the audit committee who are independent of the SOE's management and have sufficient business and financial reporting expertise can be a daunting challenge as well, especially in countries with limited capacity (see chapter 6).

\section{Undertaking an Independent External Audit}

Most SOEs have an external auditor. Some SOEs may be inspected by the supreme audit institution. However, in some jurisdictions the SAI may lack the technical capacity, mandate, or resources to effectively carry out this role. Other SOEs may be audited both by the SAI and by independent external auditors, but in that case duplication and confusion of roles and responsibilities could result. Still other SOEs follow good practice and require the independent audit of annual financial statements by a professional audit firm. A truly independent external audit contributes to the credibility of SOE financial reporting and provides reasonable assurance to the owner, investors, and the general public that the financial statements fairly represent the financial position and performance of the company.

\section{Benefits and Overall Framework}

An independent external audit of annual financial statements is an accepted standard practice in the private sector. Some jurisdictions require it for certain privately owned public interest entities-usually listed companies, banks, and other financial institutions-while other jurisdictions require an independent external audit for a much broader range of companies. The main motivation for requiring these audits is the central role that financial information plays in informing a wide array of economic agents and public bodies and in helping investors and stakeholders hold the management of audited companies accountable for their actions and performance. 
The audit provides reasonable assurance that the financial statements present fairly, in all material respects, the financial position of the entity and the results of its operations and related cash flows. Although an audit does not provide any guarantee to the various stakeholders against erroneous or fraudulent reporting, it does afford some additional protection to those who rely on the information.

An external audit can also be beneficial to management by providing useful insights into the company's main risk areas and by pointing to weaknesses in internal controls and the reporting process. In the case of a large company with a broad geographical presence and multiple business units, the external auditors normally cover those business areas that present the highest risks, and the audit can provide useful information on risks of which the company's management may be unaware.

All the benefits of a financial statement audit apply to SOEs. ${ }^{7}$ However, to ensure that the state, private shareholders, and other stakeholders derive the maximum benefit from SOE audits, several key issues need to be addressed.

First, as with other aspects of financial reporting, external audits of SOEs should generally be governed by the same rules and procedures as followed by equivalent public interest entities in the private sector. Thus, when private sector public interest entities are required to have their financial statements audited in line with International Standards on Auditing, the same provisions should apply to SOEs. SOE auditors should fall under the same regulatory and professional framework as auditors of listed companies and banks, including requirements relating to qualifications, professionalism, and independence. ${ }^{8}$ Qualifications usually include certification by a professional body and licensing by, or at least registration with, a regulator or another part of the government. Typically, both the licensing authority (or another body connected to the regulator that oversees audits) and the professional body are responsible for the professional conduct of the external auditor. External auditors should also be subject to external quality assurance.

Second, even in countries with well-established financial reporting frameworks and well-regulated professional auditors, the external auditor cannot guarantee the accuracy of the financial statements produced by an SOE. The role of the external auditor is to provide "reasonable assurance" that the financial statements are a fair statement of the SOE's financial position. It should therefore be seen as one, albeit important, part of the overall system of controls on an SOE's operations. And third, the independent auditor's report should be published together with the SOE's financial statement. 


\section{The Role of the Audit Committee}

As with privately owned public interest entities, a good practice is for the SOE board's audit committee to oversee the selection and appointment of the external auditor and the management of the audit process. In that way, the SOE's management is not directly involved in choosing the auditor, and the lines of responsibility for managing the audit process within the SOE's own governance structure are clear.

Audit committees should maintain the auditor's independence from the SOE's management. To do this, the committee may have to set out guidelines on what nonaudit services the audit firm may supply to the SOE. The committee also should consider periodically putting the audit contract out to tender or even rotating the audit firm to limit risks to the auditor's independence. Whatever approach the audit committee adopts, it should report regularly to the board and to the ownership entity and other shareholders on the actions it has taken to safeguard the independence of the auditor.

During the audit process, the audit committee should have direct communications with the external auditor and be able to meet with the external auditor without management. The audit committee should discuss the draft audit report with the auditors, and, when it has been agreed, the committee should present the report to the SOE's board and to the SOE's ownership entity. When an SOE lacks an independent audit committee, the independent directors on the board should carry out these responsibilities to prevent SOE executives from influencing the external audit.

\section{Acting on the Auditors' Conclusions}

When the external auditor's report uncovers deficiencies in an SOE's financial statements, internal controls, or risk management systems, any deficiencies should be remedied. The audit committee (or independent members of the board if there is no audit committee) should discuss reform measures with the SOE's management. At times, external pressure from the SOE's ownership entity may be necessary for ensuring appropriate actions.

\section{Implementing Independent External Audits}

Implementing independent external audits can be a challenge. Some countries, for example, may have a shortage of qualified auditors for public interest entities. Qualified auditors often represent just a small fraction of the total 
number of accountants belonging to the professional body. The Accounting and Auditing Reports on the Observance of Standards and Codes prepared by the World Bank, which review the framework for auditors, can be useful resources for improving external audits of privately owned public interest entities, including major SOEs. ${ }^{9}$

In some cases, SOEs may be unwilling to hire a qualified auditor, due either to a lack of understanding or to an inability or unwillingness to pay adequate fees. In such cases, it is important that the audit committee (or in the absence of an audit committee, the independent members of the SOE's board) and the SOE's ownership entity make the case for a rigorous, independent external audit of both accountability and enterprise effectiveness.

Last, policy makers should not think of an audit as an easy solution to poor accountability and weak reporting practices. When reporting systems generate low-quality information and internal controls are lacking, an audit will often accomplish very little. In fact, in many cases, even before the audit is initiated, the conclusion of the SOE's auditors-a disclaimer of opinion or adverse option-can be predicted based on issues raised in previous audit reports or on a basic assessment of the SOE's characteristics. In other words, some companies are not now "auditable," and in those cases requiring or commissioning an audit has very limited utility. For SOEs such as these, if an audit is not legally required, other measurestypically referred to as "agreed-upon procedures"-should be implemented to address the main weaknesses in the enterprise's internal controls and accounting processes. These actions will not only bring about real benefits for the SOE in the form of stronger controls and improved reporting but also create the conditions for a genuinely useful audit in the future. This issue highlights the importance of SOE management's taking the findings of the auditors seriously and acting on them and of the need for audit committees and ownership entities to make sure that the SOE management does so.

\section{Role of the Supreme Audit Institution}

The mission of the state auditors is usually different from that of an independent audit firm acting as the external auditor. An audit firm will focus on the proper application of accounting standards and verify the reporting systems to provide assurances on the veracity of the financial statements and the reporting process. Traditionally, the state auditor will seek to verify the legality of SOE expenditures and make certain that the SOE complies with its budget-functions essentially similar to those of the internal auditor or 
internal control. In some jurisdictions, the state auditor goes beyond this remit, in which case its resources and ability to carry out these tasks should be appraised.

The right of the state auditor to audit SOEs is usually codified in law. (In India, it is codified in the constitution.) But the state auditor may not be the only one; there are a number of variations:

- The state auditor may be the only SOE auditor, as in the Arab Republic of Egypt and Thailand.

- SOEs may be audited by a state auditor or an external auditor. In South Africa, the audit can be conducted by either the auditor general or a qualified firm; major commercial SOEs generally employ a qualified firm.

- In some countries, SOEs may opt for both. In Turkey, all SOEs are audited by the Court of Accounts but may have an external auditor, as well.

- When SOEs are audited by both a state auditor (SAI) and an external auditor, the board (or its audit committee) may oversee the external audit. This is the case in France, Poland, and many other OECD countries.

- When dual audits are carried out, the state auditor may oversee or select the external auditor, as in Estonia, India, and Peru.

If the state auditor is responsible for the only external audit, then it often needs to perform different roles to be effective: auditing financial statements and how they are produced; reviewing issues related to budgets and compliance; and, increasingly, looking at broader issues of performance and use of public funds. ${ }^{10}$ The state auditor may need specialists for each area.

The state auditor should try to avoid using its limited resources on functions that can be carried out by the SOE itself. In some countries, including Mexico and Peru, SOEs use an "internal auditor" common to the executive branch of government that carries out internal audits in ministries and agencies. However, in a number of countries the state auditor is called upon to carry out functions that would otherwise be performed by an internal auditor or control function, such as auditing expense claims and investigating internal complaints. This approach may be sufficient as a backstop-or at least better than no internal audit. But it does not contribute to the capacity of the SOE, and it may not be fully effective in focusing on main areas of concern and may have its own resource or capacity constraints. Nor does this approach allow the audit committee and board to use the internal audit most effectively to gauge what is happening inside the company. 


\section{ANNEX 7A IFC-World Bank Progression Matrix for SOEs: Transparency, Disclosure, Control Environment}

\begin{tabular}{|c|c|c|c|}
\hline $\begin{array}{l}\text { Level 1: Basic } \\
\text { corporate } \\
\text { governance practices }\end{array}$ & $\begin{array}{l}\text { Level 2: Extra steps to } \\
\text { ensure good corporate } \\
\text { governance }\end{array}$ & $\begin{array}{l}\text { Level 3: Major contribution } \\
\text { to improving corporate } \\
\text { governance nationally }\end{array}$ & Level 4: Leadership \\
\hline $\begin{array}{l}\text { Transparency and disclo } \\
\text { - SOE prepares } \\
\text { timely annual } \\
\text { financial } \\
\text { statements } \\
\text { according to } \\
\text { domestic financial } \\
\text { reporting } \\
\text { standards. } \\
\text { - SOE prepares an } \\
\text { annual report. }\end{array}$ & $\begin{array}{l}\text { - SOE prepares } \\
\text { half-yearly financial } \\
\text { statements in } \\
\text { accordance with } \\
\text { domestic financial } \\
\text { reporting standards. } \\
\text { - Annual reports include } \\
\text { management } \\
\text { commentary, SOE } \\
\text { objectives, ownership } \\
\text { and control, risks, } \\
\text { related-party } \\
\text { transactions, and basic } \\
\text { details on board } \\
\text { members. } \\
\text { - Reporting is publicly } \\
\text { available. }\end{array}$ & $\begin{array}{l}\text { - Financial statements are } \\
\text { prepared in accordance } \\
\text { with IFRS. } \\
\text { - Annual reports include } \\
\text { indirect ownership and } \\
\text { control, special state voting } \\
\text { rights, code of ethics, key } \\
\text { performance indicators, } \\
\text { compliance with corporate } \\
\text { governance code, and } \\
\text { management and board } \\
\text { remuneration. } \\
\text { - The SOE or government } \\
\text { reports on public service or } \\
\text { policy obligations. } \\
\text { - Criteria are established for } \\
\text { disclosing related-party } \\
\text { transactions with other } \\
\text { SOEs and with the } \\
\text { government. }\end{array}$ & $\begin{array}{l}\text { - Reports include } \\
\text { remuneration, risk } \\
\text { management, } \\
\text { performance against } \\
\text { KPls, environmental } \\
\text { and social reporting, } \\
\text { board attendance, } \\
\text { training, and } \\
\text { evaluations. } \\
\text { - Cost and funding of } \\
\text { public service or } \\
\text { policy obligations are } \\
\text { fully disclosed. } \\
\text { - All public disclosure } \\
\text { is available on the } \\
\text { SOE and relevant } \\
\text { government website. }\end{array}$ \\
\hline $\begin{array}{l}\text { Control environment } \\
\text { - The SOE has a } \\
\text { system of internal } \\
\text { controls in place. } \\
\text { - Internal audit } \\
\text { function in place. } \\
\text { - Annual financial } \\
\text { statements are } \\
\text { subject to an } \\
\text { independent audit. } \\
\text { - The state audit } \\
\text { institution's work is } \\
\text { clearly defined. }\end{array}$ & $\begin{array}{l}\text { - Internal controls and } \\
\text { internal audit units are } \\
\text { staffed and in place. } \\
\text { - Risk management is } \\
\text { part of the internal } \\
\text { control framework. } \\
\text { - Internal audit is } \\
\text { accountable to board. } \\
\text { - Independent external } \\
\text { audit is carried out in } \\
\text { accordance with } \\
\text { International Standards } \\
\text { on Auditing. } \\
\text { - SOE acts on issues } \\
\text { raised by the } \\
\text { independent auditor. }\end{array}$ & $\begin{array}{l}\text { - The independent external } \\
\text { audit is subject to the } \\
\text { oversight of an audit } \\
\text { committee or equivalent } \\
\text { body. } \\
\text { - Independent external } \\
\text { auditor's opinion on the } \\
\text { financial statements does } \\
\text { not contain any } \\
\text { qualification. } \\
\text { - The state audit institution } \\
\text { audits use of public funds } \\
\text { and implementation of } \\
\text { public service objectives. }\end{array}$ & $\begin{array}{l}\text { - The design of internal } \\
\text { control systems } \\
\text { complies with the } \\
2013 \text { cOSO } \\
\text { Framework. } \\
\text { - Internal audit unit } \\
\text { meets standards of } \\
\text { Institute of Internal } \\
\text { Auditors, and its } \\
\text { recommendations are } \\
\text { taken into account. } \\
\text { - Oversight is exercised } \\
\text { by a fully independent } \\
\text { audit committee and, } \\
\text { when appropriate, } \\
\text { risk committee. }\end{array}$ \\
\hline
\end{tabular}

Note: $\mathrm{KPI}=$ key performance indicators; $\mathrm{SOE}$ = state-owned enterprise. 


\section{Notes}

1. Kowalewski, Stetsyuk, and Talavera (2008) construct transparency and disclosure indexes that include key elements of nonfinancial disclosure. They show that greater transparency is correlated with a lower cost of capital and higher returns to shareholders.

2. Requirements for accounting and financial reporting for an SOE may be found in company law, the SOE's founding statutes or articles, listing requirements, and securities regulation (for a listed SOE); the banking act and financial regulation (for state-owned financial institutions); or the state's disclosure policy for SOEs. Accounting standards are often set by a professional body of accountants and auditors or the regulator of that body, although more countries are moving to independent standard setters, often with the mandate to converge local standards to IFRS.

3. The balanced scorecard is discussed in greater detail in chapter 4 .

4. Formal requirements for internal controls, in some form, have been in place for decades in the United States and many other countries. The 1987 report of the Treadway Commission highlighted the link among poor internal controls, financial fraud, and corporate bankruptcy and laid the groundwork for much of the following work in this area (Treadway 1987). Recent studies on the costs of poor internal controls include Ashbaugh-Skaife et al. (2009).

5. While the importance of an effective internal audit function is widely acknowledged, empirical studies on its benefits are limited. Recent examples include Sierra Garcia, Ruiz Barbadillo, and Orta Perez (2012); and Prawitt, Smith; and Wood (2009).

6. Institute of Internal Auditors, International Standards for the Professional Practice of Internal Auditing, https://na.theiia.org/.

7. Fan and Wong (2005) confirm the benefits of having a qualified auditor in an emerging market economy.

8. Qualifications usually include certification by a professional body and licensing by (or at least registration with) a regulator or another part of the government. Typically, both the licensing authority (or another body connected to the regulator that oversees audit) and the professional body are responsible for ensuring the professional conduct of the external auditor.

9. The Accounting and Auditing ROSCs can be found at http://www.worldbank .org/ifa/rosc_aa.html. Lessons learned and insights from Accounting and Auditing ROSCS on how to address these challenges can be found at https:// openknowledge.worldbank.org/handle/10986/14354 and http://www .worldbank. org/ifa/LessonsLearned_ROSC_AA.pdf.

10. In a handful of jurisdictions, the public sector has started using accrual accounting (a two-sided balance sheet), which may make auditing SOEs easier. But government financial information (and the supporting qualitative information) differs significantly from company financial information, and the two types should probably still be audited by different people. 


\section{References}

Ashbaugh-Skaife, Hollis, Daniel W. Collins, William R. Kinney Jr., and Ryan LaFond. 2009. "The Effect of SOX Internal Control Deficiencies on Firm Risk and Cost of Equity." Journal of Accounting Research 47 (1): 1-43.

de Luna Martinez, Jose, and Fernando Carlos Vicente. 2012. "Global Survey of Development Banks.” Policy Research Working Paper 5969. World Bank, Washington, DC.

Fan, Joseph P. H., and T. J. Wong. 2005. "Do External Auditors Perform a Corporate Governance Role in Emerging Markets? Evidence from East Asia.” Journal of Accounting Research 43: 35-72.

IIA (Institute of Internal Auditors). 2004. The Professional Practices Framework. Altamonte Springs, FL: IIA Research Foundation.

Kowalewski, Oskar, Ivan Stetsyuk, and Oleksandr Talavera. 2008. "Does Corporate Governance Determine Dividend Payouts in Poland?” Post-Communist Economies 20 (2): 203-18.

OECD (Organisation for Economic Co-operation and Development). 2004. OECD Principles of Corporate Governance. Paris: OECD.

- 2005. OECD Guidelines on Corporate Governance of State-Owned Enterprises. Paris: OECD.

Prawitt, Douglas F., Jason L. Smith, and David A. Wood. 2009. "Internal Audit Quality and Earnings Management." Accounting Review 84 (4): 1255-80.

Putrajaya Committee. 2006. The Green Book: Enhancing Board Effectiveness. Kuala Lumpur: Putrajaya Committee on GLC High Performance.

Sierra Garcia, Laura, Emiliano Ruiz Barbadillo, and Manuel Orta Perez. 2012. Audit Committee and Internal audit and the quality of Earnings: Empirical Evidence from Spanish Companies. Journal of Management and Governance (2012) 16: 305-331.

South Africa Department of Public Enterprises. 2002. Protocol on Corporate Governance in the Public Sector. Pretoria: Department of Public Enterprises.

Treadway, James C. 1987. Report of the National Commission on Fraudulent Financial Reporting. Washington, DC: National Commission on Fraudulent Financial Reporting.

World Bank. 2008. "Lessons in Reforming State Ownership of Financial Institutions: Three Country Case Studies.” Draft. World Bank, Washington, DC. 


\section{CHAPTER 8}

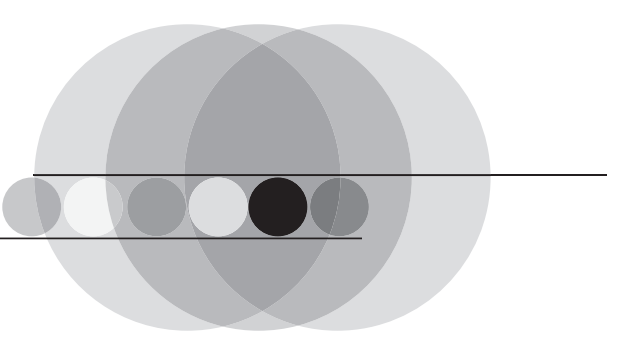

\section{Special Issues in Mixed- Ownership Companies}

As majority shareholder of a state-owned enterprise (SOE), the state exercises legitimate authority over major company decisions. Nonetheless, when part of the company's capital is held privately, special problems can arise. On the one hand, governments often pay less attention to companies in their portfolio when they have minority stakes and do not control the company. In such cases, private shareholders can take advantage of the situation, to the detriment of the state (and sometimes the company). On the other hand, in majority state-owned companies, governments can also behave in ways that work against the interests of minority shareholders. Recognizing the rights of all shareholders and promoting equitable treatment will benefit the state, as well as the minority shareholders, since the state's reputation as owner affects (positively or negatively) both the SOE's ability to attract private funding and its valuation. Moreover, by functioning as a check on costly or unreasonable demands from the ownership entity or another part of the government, equitable treatment of shareholders also can improve SOE performance. 
This chapter provides a brief overview of the main issue these arise in mixed ownership companies and describes several of the most important steps in addressing the issues:

- Assigning clear responsibility for overseeing state minority shares

- Protecting the basic rights of minority shareholders

- Promoting shareholder participation

Annex 8A provides a summary "progression matrix" to diagnose the degree to which the treatment of minority shareholders in SOEs is equitable and to suggest a pathway to reform. The matrix covers key elements of shareholder rights as set out in this chapter.

\section{Key Concepts and Definitions}

The Principles of Corporate Governance, laid out by the Organisation for Economic Co-operation and Development (OECD), name a number of basic rights of shareholders:

- The right to attend and vote in the shareholders' meeting, including voting for board members.

- The right to share in the profits of the SOE and receive dividends proportional to share ownership.

- The right to participate in major decisions, including changes to the company's articles, issuance of new shares, and approval of extraordinary transactions.

- The right to expect transparent procedures for control changes and, under certain circumstances, the ability to sell shares on the same terms as the main shareholder or to block the transaction.

- To right to understand the capital structure of the SOE, including any special rights retained by the state (golden shares), different classes of shares the SOE may have, and shareholder agreements between the state and other significant shareholders.

Good practice dictates that board members have the interests of all shareholders equally at heart. Not only is this a fair and, in some jurisdictions, a legal obligation, but also it is important for maintaining the confidence of those investors and for sustaining the share price of the SOE and its access to capital.

\section{Overview of Issues in Mixed Ownership Companies}

Mixed ownership results when a government or ownership entity chooses a strategic private sector partner to invest in an SOE (normally to gain access 
to commercial and industry experience), establishes a new SOE in partnership with the private sector, or partially privatizes an enterprise, through a partial public listing on a stock market, for example.

This model of mixed ownership has become increasingly common for larger SOEs. Mixed ownership provides a source of finance for the SOE and the government and may play an important part in reforming and commercializing the SOE and in introducing governance practices found in other listed companies. Governments may elect partial privatization as a way to raise funds or promote the development of the capital markets, while still retaining control of the SOE.

Mixed ownership, however, also poses specific governance challenges. Because the state typically retains a large ownership share, the government (or ownership entity) can choose all board members and make major decisions unilaterally. Even when the state's direct ownership share is smaller, the state may retain a high degree of control through government-linked investors, shares held through other SOEs, or special legal rights known as "golden shares." If the government or ownership entity exploits its control rights and pursues its interests to the disadvantage of other shareholders, the potential benefits of listing an SOE or bringing in other shareholders will be undermined. ${ }^{1}$ Investor confidence and asset values will suffer, limiting the SOE's access to private finance and affecting retirement and other savings. Equitable treatment is thus crucial to achieving the benefits that mixed ownership can bring.

When the government does not control the company, the opposite is also common: other shareholders can take advantage of the weak position of the government as shareholder. Because of the difficulties that governments sometimes have in effectively managing their shareholdings, partially owned SOEs sometimes fall under the control of nongovernment shareholders who can use their dominant position to extract rents from their shareholding (for instance, through abusive relatedparty transactions).

Several of the most important institutional issues related to companies with mixed ownership are discussed elsewhere in this toolkit, including (1) an objective board with fiduciary responsibility and adequate resources; (2) an effective audit committee, internal audit, and internal controls; and (3) transparency and disclosure, including the provision of information to other shareholders. Ideally, SOE ownership entities should include minority state-owned company shares to prevent abuse while acting as a strong partner with other (controlling) investors.

In many emerging market economies, the overall framework for corporate governance may also be relatively weak, with critical gaps in 
shareholder protection even for listed companies. This possibility increases the potential for abusive treatment of other shareholders and further reduces investor confidence. In these cases, to protect their own interests, governments should pursue broad-based corporate governance and investor protection reforms. These reforms include legal and regulatory reform and the creation of new institutions that support good corporate governance. The assessments of corporate governance carried out by the World Bank under its Reports on the Observance of Standards and Codes review in detail a country's framework for shareholder rights and treatment. ${ }^{2}$ While their main focus is on listed companies, which include many SOEs with nonstate shareholders, these reports also include information relevant for the treatment of shareholders in unlisted SOEs.

Beyond broader corporate governance improvements, SOEs should work to protect the basic rights of shareholders and to encourage appropriate participation by other shareholders in the governance of the company.

\section{Overseeing State Minority Shares}

In many instances governments have chosen to maintain some degree of ownership in private companies but do not have control. They continue to hold these stakes for many reasons, including financial, informational, and reputational. Depending on the shareholding structure of each company, other shareholders are typically a combination of two main types: (1) strategic investors who will control and manage the company; and (2) individual and institutional investors through public subscription.

In both cases, assigning clear responsibility for managing the shareholder relationship is essential. In line with good corporate governance practice, the state should be an active, informed, and consistent shareholder; should work to improve corporate governance; and should vote (or prepare recommendations for voting) on all exceptional situations that require shareholder approval, notably those with significant financial implications. The state or ownership entity should also take into account other good practices:

- The ownership entity should have a transparent set of overall objectives that guides both its ongoing transactions with the private sector and the management of its residual ownership stakes.

- Overall objectives should be periodically reviewed to ensure that they remain relevant. 
- Any golden share rights should be exercised only in accordance with predefined criteria, established according to the overall ownership objectives and the specific ownership objectives of the partner entity in which the golden share is held.

Accordingly, the ownership entity (or other government bodies) has several key tasks:

- To work closely with companies and stakeholders in promoting good corporate governance. The ownership entity should work to build a partnership with the management and board of investee companies and monitor and promote good corporate governance practices. When acting as a minority shareholder, the ownership entity should:

- Be vigilant in detecting corporate governance challenges (conflicts cases, CEO succession, special accounting issues, increasing complexity of the business) and encourage the company to request assistance, as needed, in adjusting its governance practices to meet such challenges.

- Keep abreast of developing corporate governance standards, and encourage the investee companies to take these into consideration and adapt them appropriately to the partner company's particular circumstances.

- Ensure that all members of the board of directors know what resources are available to support them in their work (including any local institute of directors). They should receive adequate orientation on the partner company and, where practical, formal continuous professional training for their role as directors.

- Seek support and assistance from outside consultants and advisers, as required.

- To propose prospective board members and promote revision of board performance. When appropriate and where possible, the ownership entity should make recommendations on board nominations. Following the appointment or election, it should monitor the performance of that board member (and that of the rest of the board). The ownership entity should monitor and promote good corporate governance practices, in particular, by training nominated directors to become change agents for good corporate governance. Where resources permit, it should evaluate the role and functioning of the board of directors and the quality of information provided by management to the board and shareholders.

- To vote company shares at shareholder meetings. The ownership entity should assume prime responsibility for preparing voting positions for 
items to be considered at every shareholders' meeting, and (resources permitting) its representatives should attend the meeting in person.

- To take action to prevent violation of ownership entity rights or agreements. The ownership entity should strive to work in partnership with the company and all stakeholders. But in the event that ownership entity rights are systematically violated or criminal actions are detected, it should take the lead in protecting such rights, with the courts or other authorities.

- To develop specific comprehensive processes. The ownership entity should set up processes for developing voting positions; for having senior management sign off on those voting positions; and then for exercising the votes at the general meeting, which is critical to ensuring protection of the ownership entity's rights.

- To monitor the performance of the investee companies and ensure that regular and timely reporting takes place. The ownership entity should be responsible for understanding the goals of the investee companies and for monitoring and evaluating their subsequent performance. The ownership entity will then be able to take action as an informed shareholder.

- To develop and maintain shareholder policy guidelines. The ownership entity should develop a set of policies on how it will own and vote its shares and disclose them on its website.

- To develop and maintain a policy on inside information. When an ownership entity is responsible for minority positions in listed companies, its employees or consultants could be in receipt of inside information. Insider dealing (that is, exploiting internal information through purchase or sale of securities) and the unauthorized release of inside information are criminal offences in many countries. The ownership entity should develop and periodically review an internal policy on insider dealing so that no restricted person (director, manager, investment officer, consultant, or other staff) with access to material and confidential information related to a partner company may buy or sell securities of that company.

\section{Protecting the Basic Rights of Minority Shareholders}

Company laws and national corporate governance codes set out the rights that all shareholders should enjoy so that all shareholders are treated equitably. Many of these rights will be spelled out in company law, which typically governs an SOE that has other shareholders. If an SOE is formed under its 
own act, then founding law or articles of association should contain similar provisions for nonstate shareholders.

When SOEs have strategic investors from the private sector, the rules on the equitable treatment of shareholders are normally established through detailed shareholder agreements between the strategic investor and the government. However, when private sector shareholders are more dispersed-including large SOEs that may have millions of shares held by individuals, pension funds, insurance companies, and mutual fundsgeneral policy controls are important for ensuring equitable treatment of all shareholders.

In a number of jurisdictions, government policies conflict with or undermine minority shareholder rights. Government policy on board appointment or approval of extraordinary transactions may simply ignore the presence of other shareholders. Similarly, shareholder rights relating to control changes or capital increases are sometimes not respected when the government plans the sale of a major stake or when the SOE plans a capital increase at the government's request.

SOE policies should acknowledge and respect shareholder rights as spelled out in law and in relevant corporate governance codes or policies. For example, in India, Peru, and South Africa, as well as in many OECD countries, shareholder rights are recognized through the relevant company acts and rules for listed companies; such documents prohibit companies from discriminating between shareholders and reinforce government SOE policies, as well.

The right to share in the profits of the SOE has important implications. Dividend policies may be a useful tool for the ownership entity and, if they lead to regular dividends for investors, can build the confidence of other shareholders. But some governments impose special levies or contributions that SOEs must make to the budget-and that are not approved by shareholders. An unfunded liability resulting from policy objectives or programs imposed on the SOE is analogous to a special levy, undermining shareholder returns and investor confidence. These can be a serious violation of shareholder rights and should be avoided.

Traditionally, when SOEs have undergone a partial privatization, the state has retained a so-called golden share that gives it special rights beyond voting its shares (for example, approving control changes or other major transactions or in making a certain number of board appointments). These rights might be enumerated in the company articles, included in a licensing agreement accompanying the privatization, or be attached to shares with special rights. In many countries today, the state no longer retains such powers because they are seen as an unnecessary restriction 
on shareholder rights. At a minimum, these special rights should be fully disclosed.

The progression matrix at the end of this chapter presents the key steps in ensuring shareholder rights. At its most basic, the company's legal framework should treat all shareholders of the same class equally with respect to voting rights, subscription rights, and transfer rights. Changing the articles requires supermajority approval. And all shareholders should receive dividends.

Companies that take extra steps toward good corporate governance will provide shareholders with accurate and timely information on the number of shares of all classes held by the state and other major shareholders. Companies and governments that go further will make sure that the rights of shareholders are protected during new share issues and changes of control, including privatization and renationalization, and that all securities' holders are treated equally with respect to information disclosure (fair disclosure).

In companies operating at the highest degree of good practice, the state will have no special rights in the company beyond its ownership. The company's history of equitable treatment of shareholders will meet international market expectations.

\section{Promoting Shareholder Participation}

In addition to upholding the basic rights of shareholders, governments and SOE directors may build investor confidence and make minority shareholders feel like company co-owners. These steps are particularly relevant for the many SOEs in which the state is truly a dominant shareholder with a stake large enough-typically 75 percent or more-to allow it to make almost any decision unilaterally. Governments and SOE directors may take further steps to maintain equitable treatment of shareholders:

- Encouraging shareholders to participate actively in the annual shareholders' meeting

- Allowing minority shareholders to influence the nomination and selection of board members

- Protecting against abusive related-party transactions

\section{Encouraging Participation in the Shareholders' Meeting}

Annual shareholders' meetings help hold the board of directors and the SOE accountable. Annual meetings are generally required by law for an SOE that 
has multiple shareholders. Some actions can limit participation, including poor notice of the meeting, requiring shareholders to submit confirmation of their ownership status or register to participate, and holding the meeting at an inconvenient location or on an inconvenient date (for example, when many other companies are having annual meetings). In some jurisdictions, shareholders have little practical ability to alter the agenda or ask questions at the meeting.

In contrast, many SOEs now actively encourage shareholders to participate in their annual meeting. One example is Brazil's Sabesp. The company provides 30 days' notice of its annual meeting (rather than the standard 15) and widely publicizes the event. In addition, Sabesp's bylaws allow shareholders to deliver documentary evidence of their status at any time up to the moment the meeting is called to order. (The usual practice in Brazil is to require documentary proof of share ownership at least 48 hours before the meeting.)

In Burkina Faso, even SOEs wholly owned by the government are required to have an annual meeting presided over by the council of ministers and the prime minister and open to the public. During the meeting, problems are exposed, directives issued, and resolutions taken. The ability of the public to participate helps explain the success of these meetings.

Prominent SOEs may have thousands of shareholders participating. In countries with active corporate cultures and stronger corporate governance, meetings tend to be better attended and have more active participation. However, where private sector meetings are merely procedural, with participation discouraged, SOE meetings tend to follow the same pattern. Under such circumstances, SOEs could take the initiative in reaching out to shareholders and even to the public.

The progression matrix at the end of this chapter offers ways to encourage shareholder participation in shareholder meetings. Companies that take extra steps to ensure good corporate governance will remove any obstacles to shareholder participation in meetings. Companies that go further see that minority shareholders can ask questions at the shareholders' meeting and influence its agenda.

\section{Allowing Representation of Minority Shareholders on SOE Boards}

Minority shareholders may be able to vote for board members. However, the results may be a foregone conclusion, with the state using its controlling shares to choose each board member. While board members are duty bound to represent the interests of all shareholders equally, in 
practice board members may be biased in favor of the authority responsible for their appointment. To promote a more representative board, some jurisdictions empower minority shareholders to influence the nomination and election of board members or select a representative on the board to pay particular attention to minority shareholder rights.

This empowerment of minority shareholders may be achieved in different ways. For instance, to nominate a board candidate, small shareholders may be allowed to provide input into the nomination committee (if the board has one). Alternatively, small shareholders may be permitted to nominate candidates directly if, for example, a certain percentage of shareholders support the choice. At the time of board elections, a cumulative voting rule can be used, in which shareholders may not only vote yes or no but also cast all their votes (for all their shares) for a single nominee. Alternatively, the election process could designate one or two board positions for whom only small shareholders may vote or adopt some form of proportional representation.

Clearly, practice in this area varies. Policy in some jurisdictions directly supports board representation of the nonstate minority shareholders. However, as Malaysia's Green Book for government-linked companies illustrates, this policy usually applies only to significant shareholders, not blocks of smaller shareholders (Putrajaya Committee 2006). Romania recently introduced cumulative voting for SOE boards to allow for minority shareholder representation. Italy, Spain, Sweden, and other OECD countries provide minority shareholders' rights for participation on the board or for nomination of board members.

The progression matrix at the end of this chapter presents the key steps in encouraging shareholder participation in shareholder meetings. Companies that take extra steps to embed good corporate governance will ensure that minority shareholders can nominate board members before shareholder meetings. Companies that go further will make sure that minority shareholders are able to be represented on the board, through cumulative voting or similar mechanisms.

\section{Protecting against Abusive Related-Party Transactions}

Transactions in which board members, management, or influential shareholders have a conflict of interest are prone to abuse. In private sector companies, all too often related-party transactions have channeled resources away from the company and minority shareholders. In SOEs, most guidance 
on these conflicts of interests focuses on the role of the board and disclosure. For example, India's corporate governance guidelines for central public sector enterprises call for potential related-party transactions to be reviewed by the audit committee, approved by disinterested board members, and disclosed to the public.

In addition to these good practice requirements, listed companiesincluding listed SOEs-will often require shareholder approval of any related-party transaction that exceeds a certain size or crosses another specific threshold. In some jurisdictions, only disinterested shareholdersusually those that are not the controlling shareholder-may approve a related-party transaction before it takes place. Rules such as these may be established as statutory requirements for all SOEs or may be part of the articles for specific SOEs.

As a practical problem, it is sometimes hard to determine when another SOE or part of the government is a related party. In some jurisdictions, other SOEs or parts of the government are never treated as a related party, even when a common controlling ministry or other party may use its influence to encourage certain kinds of transactions or set terms for those transactions (sometimes through publicly disclosed policies). Other jurisdictions seem to determine on an ad hoc basis what constitutes a related party. One point of reference is the International Financial Reporting Standards. The main international standard for disclosure of related-party transactions, IAS 24, does not require treating all transactions between SOEs or between SOEs and the government as related-party transactions. However, it does require disclosing such transactions if they are individually or collectively significant or contracted on nonmarket terms. In general, a good approach is for SOE policies to treat all such transactions as related-party transactions.

The progression matrix at the end of this chapter (annex 8A) presents an important step in protecting minority shareholders from abusive relatedparty transactions. Companies should make sure that they have a policy on related-party transactions that addresses transactions with the government and other SOEs that require interested shareholders to recuse themselves. 
ANNEX 8A IFC-World Bank Progression Matrix for State-Owned Enterprises: Shareholder Rights

\begin{tabular}{|c|c|c|c|}
\hline $\begin{array}{l}\text { Level 1: Acceptable } \\
\text { corporate governance } \\
\text { practices }\end{array}$ & $\begin{array}{l}\text { Level 2: Extra steps to } \\
\text { ensure good corporate } \\
\text { governance }\end{array}$ & $\begin{array}{l}\text { Level 3: Major contribution to } \\
\text { improving corporate } \\
\text { governance nationally }\end{array}$ & $\begin{array}{l}\text { Level 4: } \\
\text { Leadership }\end{array}$ \\
\hline $\begin{array}{l}\text { - The company's legal } \\
\text { framework treats all } \\
\text { shareholders of the } \\
\text { same class equally with } \\
\text { respect to voting rights, } \\
\text { subscription rights, and } \\
\text { transfer rights. } \\
\text { - Shareholders participate } \\
\text { in the shareholders' } \\
\text { meeting and receive } \\
\text { dividends. } \\
\text { - Changing the articles } \\
\text { requires supermajority } \\
\text { approval. }\end{array}$ & $\begin{array}{l}\text { - Shareholders are } \\
\text { provided with accurate } \\
\text { and timely information } \\
\text { on the number of } \\
\text { shares of all classes } \\
\text { held by the state and } \\
\text { other major } \\
\text { shareholders. } \\
\text { - The SOE encourages } \\
\text { minority shareholders } \\
\text { to participate in the } \\
\text { shareholders' } \\
\text { meeting. } \\
\text { - Minority shareholders } \\
\text { may nominate board } \\
\text { members. }\end{array}$ & $\begin{array}{l}\text { - Rights of shareholders are } \\
\text { protected during new-share } \\
\text { issues and changes of } \\
\text { control, including } \\
\text { privatizations and } \\
\text { renationalization. } \\
\text { - Shareholders are provided } \\
\text { details on special rights the } \\
\text { state has in the SOE (golden } \\
\text { shares) and control through } \\
\text { government-linked entities. } \\
\text { - Rules on related-party } \\
\text { transactions address } \\
\text { transactions with the } \\
\text { government and other SOEs } \\
\text { and require recusal by } \\
\text { interested shareholders. } \\
\text { - Effective board } \\
\text { representation of minority } \\
\text { shareholders is provided by } \\
\text { cumulative voting or similar } \\
\text { mechanisms. } \\
\text { - Minority shareholders can } \\
\text { ask questions at the } \\
\text { shareholders' meeting and } \\
\text { influence its agenda. } \\
\text { - All securities' holders are } \\
\text { treated equally with respect } \\
\text { to information disclosure (fair } \\
\text { disclosure). }\end{array}$ & $\begin{array}{l}\text { - The state has no } \\
\text { special rights in } \\
\text { the company } \\
\text { (golden shares) } \\
\text { beyond its } \\
\text { ownership. } \\
\text { - Supermajority } \\
\text { approval is } \\
\text { required for } \\
\text { large, } \\
\text { extraordinary } \\
\text { transactions. } \\
\text { - The SOE's } \\
\text { history of } \\
\text { equitable } \\
\text { treatment of } \\
\text { shareholders } \\
\text { evidences } \\
\text { consistent } \\
\text { conformity with } \\
\text { international } \\
\text { market } \\
\text { expectations. }\end{array}$ \\
\hline
\end{tabular}

\section{Notes}

1. Studies provide evidence on the benefits of minority shareholder protection in listed companies in emerging markets. For example, Qian and Zhao (2011) show that representation of minority shareholders on the board can reduce expropriation by the controlling shareholder. Atanasov et al. (2006) and Nenova (2003) present cases confirming that greater legal protection for minority shareholders increases share prices and willingness to invest.

2. Corporate Governance ROSCs can be found at http://www.worldbank.org/ifa /rosc_cg.html. 


\section{References}

Atanasov, Vladimir, Bernard Black, Conrad S. Ciccotello, and Stanley B. Gyoshev. 2006. "How Does Law Affect Finance? An Empirical Examination of Tunneling in an Emerging Market." Finance Working Paper 123/2006, European Corporate Governance Institute, Brussels.

Nenova, Tatiana. 2003. "The Value of Corporate Voting Rights and Control: A Cross-Country Analysis.” Journal of Financial Economics 68 (3): 325-51.

OECD (Organisation for Economic Co-operation and Development. 2004. OECD Principles of Corporate Governance. Paris: OECD.

Putrajaya Committee. 2006. The Green Book: Enhancing Board Effectiveness. Kuala Lumpur: Putrajaya Committee on GLC High Performance.

Qian, Jun, and Shan Zhao. 2011. "Do Shareholder Rights Matter? Evidence from a Quasi-Natural Experiment.” Paper presented at the Third International Conference on Corporate Governance in Emerging Markets, Korea University Business School, Seoul. 



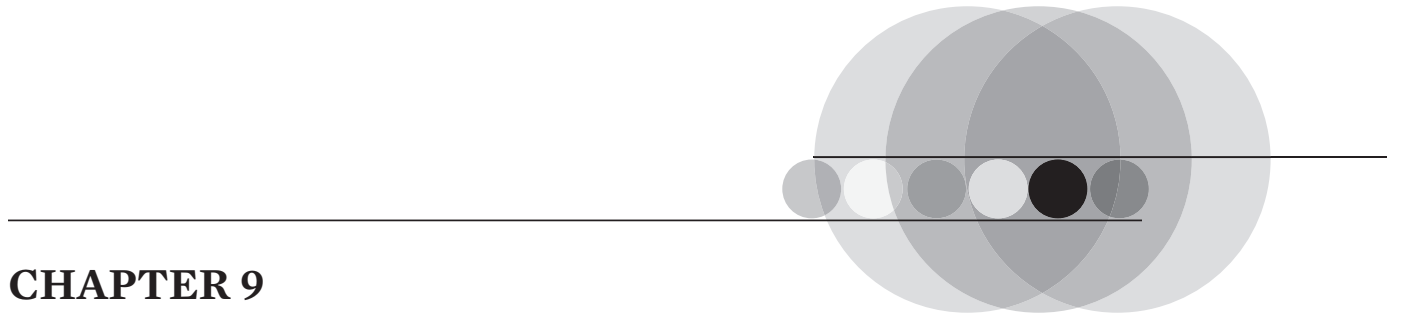

\section{Implementing Reform}

With all the challenges facing state-owned enterprises (SOEs), how can their boards and state owners advance corporate governance reforms? This toolkit has described a number of good practices, actions, and experiences gathered from a wide range of countries and relevant to both the state as owner and to specific companies. These pertain to the need for:

- Establishing a sound legal and regulatory framework for SOE governance by: bringing SOEs under company law and applying other laws and regulations to SOEs to create a level playing field; listing them on the stock markets to instill capital market discipline; developing modern SOE laws and regulations; and uniting SOEs under a national code of corporate governance or creating a specific SOE code to codify good practices (chapter 2).

- Creating effective ownership arrangements for state oversight and accountability by: identifying and separating ownership functions from the state's policy making and regulatory functions; streamlining and focusing the role of ministries on core ownership functions where they remain owners; creating safeguards against government interventions; and centralizing the state's ownership functions to bring focus, consistency, and good practices to the SOE sector (chapter 3). 
- Developing proper performance-monitoring systems by: defining SOE mandates, strategies, and objectives; developing key performance indicators and targets, both financial and nonfinancial; establishing performance agreements between SOE owners and SOE boards; and measuring and evaluating performance to hold SOEs more accountable for results and to ensure good performance (chapter 4).

- Promoting financial and fiscal discipline by: reducing preferential access to direct and indirect public financing; identifying, computing, and financing the true cost of public service obligations; and monitoring and managing the fiscal burden and potential fiscal risk of SOEs (chapter 5).

- Professionalizing SOE boards by: developing a structured and transparent process for board nominations; defining the respective roles of the state as owner, of boards, and of management and empowering boards to carry out core responsibilities such as strategy setting, choosing and overseeing the CEO, and managing risks; enhancing board professionalism through the separation of chair and CEO, development of board committees, and the like; putting in place board remuneration and evaluation policies and practices; and providing training to board directors (chapter 6).

- Enhancing transparency, disclosure, and controls by: applying private sector principles and international standards to SOEs; improving SOE reporting and disclosure; strengthening the internal control environment; and carrying out independent external audits (chapter 7).

- Protecting shareholder rights in mixed-ownership companies by: overseeing minority government stakes; promoting shareholder participation and equitable treatment of shareholders; encouraging participation in the shareholders' meeting; ensuring representation of minority shareholders on SOE boards; and protecting against abusive related-party transactions (chapter 8).

Diagnosing governance challenges and developing appropriate policy and technical solutions in these areas are critical starting points in reform. But the real challenge is one of implementation, the key to which is contextualizing reforms and paying attention to the reform process itself.

\section{Contextualizing Reform}

Given the wide range of circumstances in different countries and sectors and among SOEs themselves, there can be no "one-size-fits-all" approach to improving SOE governance, and reform will need to be context specific. 
From the outset, country contexts create important differences in setting reform priorities and pathways. A stylized classification of countries based on their salient features highlights possible differences:

- Countries with generally good overall governance-supported by the rule of law, functioning institutions, relatively robust implementation capacity, and an operational private sector-may have fewer SOE governance problems and may find it easier to address those that do arise and implement the many reforms highlighted in this toolkit. Strong national corporate governance models in such countries can also have secondary effects on SOE governance. In such cases, adopting good practices or moving toward them is less challenging.

- By contrast, low-income countries-especially fragile or postconflict states, where the state is the only sizable actor-may face severe governance challenges of rent seeking and capture. When combined with low or no implementation capacity, these challenges make governance reforms especially pressing but at the same time difficult to implement. In such circumstances, a first step may be to gather basic information on the SOE sector and build institutional capacity before launching more advanced reforms. Improving the performance of a few key institutions on a case-by-case basis so that they can serve as "islands of effectiveness" could also provide demonstration effects for reform of the broader SOE sector as a whole.

- In countries where, because of strong Socialist legacies, SOEs predominate across all sectors and experience intrusive political interference in SOE supervision and management structures, the priorities may be to put in place the basic legal framework that positions the state more as an owner and less as an entrepreneur or coordinator. Building awareness of the roles and responsibilities of the state as shareholder, of boards, and of management is also an importance task. In many such countries, problems of nonperforming loans held by state-owned financial institutions and directed lending to SOEs may also need to be resolved.

- In developmental states where the state is still present and dominates key sectors of the economy, corporate governance reforms will need to go hand in hand with broader reforms aimed at increasing competition and building strong sectoral regulators.

A study by the Organisation for Economic Co-operation and Development (OECD) on SOEs in the Middle East and North Africa region provides a classification of the role of the state vis-à-vis SOEs, which varies with the national political economy and development model, and articulates associated reform challenges (table 9.1). 
SOE governance problems and approaches also vary by sector, although to a lesser extent and more as a matter of emphasis than of fundamental differences in approach. Compared to nonfinancial SOEs, financial SOEs, for example, may require special attention, given their complex incentive structures in which depositors are important stakeholders, their heavy regulation and supervision, and the difficulty of monitoring them. They require an even greater focus on internal controls, auditing, reporting, oversight, and risk management, although these factors are increasingly important in large and complex nonfinancial SOEs.

Variations by type of SOE also need to be taken into account, for example:

- SOEs that have public policy mandates or public policy goals or that are operating as monopolies may be more difficult to reform and require different approaches-such as the separation of commercial and noncommercial objectives-from SOEs that operate in highly competitive markets where pressures to improve corporate governance are higher.

TABLE 9.1 Classification of the State-Owned Enterprise Sector in the Middle East and North Africa

\begin{tabular}{|c|c|c|}
\hline Countries & State-owned enterprise sector & Country priorities \\
\hline $\begin{array}{l}\text { Algeria; Egypt, } \\
\text { Arab Rep.; Libya; } \\
\text { Syrian Arab } \\
\text { Republic }\end{array}$ & $\begin{array}{l}\text { Large SOE sectors owing to the Socialist } \\
\text { legacy; banking sector historically dominated } \\
\text { by the state; high nonperforming loans in } \\
\text { state-owned banks; state seen as a major } \\
\text { source of employment. }\end{array}$ & $\begin{array}{l}\text { Rethinking the role of the state in specific } \\
\text { sectors such as textiles and food } \\
\text { processing; reorganization of the state- } \\
\text { ownership function; reducing political } \\
\text { interference on SOE boards; streamlining } \\
\text { legal framework applicable to SOEs. }\end{array}$ \\
\hline $\begin{array}{l}\text { Bahrain, Kuwait, } \\
\text { Oman, Qatar, } \\
\text { Saudi Arabia, } \\
\text { United Arab } \\
\text { Emirates }\end{array}$ & $\begin{array}{l}\text { Oil and gas SOEs not listed and a key source } \\
\text { of fiscal revenues; minority stakes in } \\
\text { nonstrategic SOEs listed in part to develop } \\
\text { capital markets; new SOEs being established } \\
\text { in recent years; Sovereign Wealth Funds, } \\
\text { important owners of listed and unlisted } \\
\text { companies. }\end{array}$ & $\begin{array}{l}\text { Improving SOE transparency and } \\
\text { accountability; preparing listings of } \\
\text { minority stakes in some SOEs; } \\
\text { consolidating SOE ownership under } \\
\text { professional management; reproducing } \\
\text { successful ownership experiences in } \\
\text { other SOEs. }\end{array}$ \\
\hline Iraq; Yemen, Rep. & $\begin{array}{l}\text { Numerous unincorporated enterprises; SOEs } \\
\text { major recipient of state subsidies; state seen } \\
\text { as an employer of last resort; some interest } \\
\text { in privatizing SOEs. }\end{array}$ & $\begin{array}{l}\text { Corporatization of SOEs and preparation } \\
\text { of some SOEs for privatization; creation } \\
\text { of mechanisms to reduce redundant } \\
\text { employment in the SOE sector; review of } \\
\text { the legal framework applicable to SOEs. }\end{array}$ \\
\hline $\begin{array}{l}\text { Lebanon, Jordan, } \\
\text { Morocco, Tunisia }\end{array}$ & $\begin{array}{l}\text { Rationalization of SOEs through their } \\
\text { privatization during 1980s and 1990s; state } \\
\text { present in select sectors and generally not } \\
\text { seen as a major source of employment; } \\
\text { SOEs are not highly present in the financial } \\
\text { sector but remain active in network } \\
\text { industries. }\end{array}$ & $\begin{array}{l}\text { Review of state ownership in loss-making } \\
\text { enterprises; better coordination of the } \\
\text { state's ownership function; improvement } \\
\text { of the professionalism of SOE boards; } \\
\text { reduction of political interference in SOE } \\
\text { boards; separation of ownership and } \\
\text { regulatory functions. }\end{array}$ \\
\hline
\end{tabular}

Source: OECD 2012. 
- For nonstrategic SOEs or loss-making SOEs that are leftovers from the privatization process or that are a legacy of a Socialist economy, improvements in corporate governance alone are not likely to solve performance problems; other solutions-such as restructuring, divestment, and bankruptcy, accompanied by measures to mitigate the social impact-may be more relevant.

- Companies listed on the stock exchange must comply with the much tighter corporate governance requirements of the exchange, while unlisted companies may face few pressures to fulfill such requirements and where monitoring and ensuring compliance is important.

In sum, these variations highlight the need for flexibility in designing reform priorities and pathways and in tailoring them to the economic, political, and social norms and traditions, as well as to the realities SOEs and their governments are facing. The pace and sequencing of SOE governance reforms will also need to be calibrated to the capacity of the implementing agencies and the needs of individual enterprises. The lack of political will and weak administrative capacity, for example, may make good practice or "first best" options impractical, while "second best" solutions may be more appropriate. Thus, a range of solutions that are both technically sound and politically feasible should be considered within a given context.

\section{Paying Attention to the Reform Process}

Governance reforms-and SOE reforms more broadly-can be both politically contentious and institutionally challenging to implement. Vested interests within SOEs and government are often resistant to change: SOE management sees better governance as a threat to its independence; SOE boards can see reform as a threat to their positions; and line ministries are resistant to changes that threaten their capacity to use the SOEs within their control to meet their objectives. Outside of government, stakeholders can also oppose change. Employees can be worried about job security, when reform is tied to efficiency or operational improvements within SOEs. Preferred suppliers and customers can object to greater transparency in SOE commercial dealings, and other shareholders might prefer the status quo, particularly if an SOE receives benefits because of its government ownership. Institutional constraints and the lack of capacity can also impede implementation, since governance reforms require fundamental changes in organization, incentives, and behavior that can be difficult to achieve. 
Moreover, as the reform process unfolds, reforms can move forward, but they can also slide backward or become stuck in midstream. A recent OECD report highlights the example of the Lebanese telecom sector, which illustrates some of the challenges and pitfalls of reform. In 2002, the Lebanese government passed the Telecommunications Act to establish the legal framework for creation of Liban Telecom as a joint-stock company, effectively transferring the commercial activities from the Ministry of Telecommunications and at the same time setting up the Telecom Regulatory Authority. Although the regulatory authority was established, the company was never constituted. As a result, most telecom services continue to be provided directly by the ministry, which the regulator does not have the mandate to oversee. This situation has reportedly resulted in serious conflicts of interest. For instance, a director of the Ministry of Telecommunications was appointed chairman and general manager of OGERO, a Lebanese SOE that contracts with the same ministry to provide fixed-line and Internet services (OECD 2012).

In short, SOE governance reform is an ongoing process that often evolves over long periods of time, as the case of India (box 9.1) shows. Moreover while technocratic solutions are necessary, they are not sufficient. Diagnosing governance challenges and developing policy and technical solutions are critical starting points, but these are not enough. Managing the implementation process itself is just as important as designing the technical content of reform. Obtaining political support, creating incentives, and building the commitment of the government and SOE managers to improving governance are key steps. Experience from reformers suggests several actions that policy makers can take to promote and support the cause of SOE governance reform.

\section{Gathering and Publishing Comprehensive Data on SOE Performance}

Consistent, reliable, and timely data on SOEs are often lacking or not available, and in the absence of such data the size, scope, and costs of state ownership to the economy are not fully understood. A first step in many countries, therefore, is to build and gather basic data on SOEs. Data on the direct and indirect financial costs to government of supporting SOEs through capital injections, soft loans, subsidies, tax breaks, and the cost of capital are often hard to get, but gathering and publishing such information can help expose the costs of state ownership to the economy as a whole and frame the debate on the rationale for reform. Aggregate data can also provide a baseline against which to measure the success of subsequent policy changes. 
BOX 9.1

\section{SOE Corporate Governance Reforms in India}

Central public sector enterprises (CPSEs) and other public sector undertakings have long played an important role in the Indian economy. As of March 2013, 277 CPSEs were operating across 22 sectors, including key sectors such as public utilities, transportation, coal, and oil and gas, producing just over 6 percent of gross domestic product (GDP) on a value-added basis and employing 1.4 million full-time employees (excluding casual and contract workers). CPSEs are important capital market players; 44 are listed on the various stock exchanges and include some of the largest listed companies. Their total market capitalization in March 2013 accounted for over 20 percent of the market capitalization of the Bombay Stock Exchange.

CPSE reform has been a critical component of India's broader economic policy for more than five decades. As early as 1956, the Industrial Policy Resolution called for CPSEs to be given greater autonomy and be organized on business lines. In 1965, the Bureau of Public Enterprises, later the Department of Public Enterprises (DPE), was established to report on CPSE performance. In the mid-1980s a performance monitoring system known as the Memorandum of Understanding (MOU) system was introduced to increase enterprise accountability and financial sustainability (in 2012-13, 195 MOUs have been signed between CPSEs and their overseeing line ministries/departments). Reforms during the 1990s focused on liberalization and deregulation of most sectors, delegation of substantial decision-making powers to the boards of leading CPSEs, and the further development of the MOU system (with financial and physical performance targets introduced in 2004-05). From the late 1990s to 2004, the focus was on disinvestment and privatization through minority share sales on the stock market and strategic sales through open tender.

In 2004, the National Common Minimum Program reaffirmed the government of India's commitment to the state-owned sector, and governance reforms gained prominence. In addition to pledging that profitable CPSEs would not be privatized, the program encouraged CPSEs to raise resources through the capital markets and called for the devolution of full managerial and commercial autonomy to the boards of large profit-making companies in competitive sectors that were empowered

(box continues on next page) 
BOX 9.1 continued

to make certain investments and other decisions without government approval. These and other steps to strengthen CPSE boards and enhance transparency evolved into a more comprehensive governance approach, culminating with the issuance in 2007 of the OECD's Guidelines on Corporate Governance of State-Owned Enterprises. Patterned on clause 49 of the listing agreement issued by the Securities and Exchange Board of India in 2000 and subsequently modified in 2003-04, the voluntary guidelines aim to improve board practices and other elements of corporate governance in all CPSEs, including unlisted enterprises.

The governance framework for CPSEs is consistent with several aspects of international good practice, including substantial progress in removing barriers to competition, reducing government financial support, and listing of CPSEs on the capital markets. Almost all CPSEs are corporatized and come under the same laws as private sector companies. Key decision-making powers have been delegated to leading enterprises and other profitable CPSEs. Memorandums of understanding have been signed by most CPSEs and have emerged as a key tool for monitoring and motivating performance. Clause 49 of the listing agreement has helped put listed CPSEs on the same footing as private companies, and the 2007 corporate governance guidelines have helped extend these practices to unlisted CPSEs. CPSE boards are required to have independent members and are now bringing in directors with private sector experience, while a public enterprises selection board, overseen by an independent board and supported by the Ministry of Personnel, has been set up to manage the process of selecting board members through tenders, advertising, interview panels, and preparation of short lists. The public has access to extensive information on CPSEs, at both the sector and the enterprise level. CPSE disclosure standards are comparable to those in many OECD countries, while the Right to Information Act has pushed the frontier even further. The Standing Committee on Public Enterprises, a membership body for CPSEs and other state companies, acts as an interface between the government of India and CPSEs and organizes conferences and training, including training on corporate governance, for its members.

These measures have laid the foundation for further deepening of CPSE corporate governance reforms, reforms that will ultimately enable them to realize the potential benefits of a higher level of performance. Critical differences with the private sector still remain, with certain 
BOX 9.1 continued

legal and financial privileges favoring CPSEs, on the one hand, and social obligations and human resource rules constraining them, on the other. Institutional arrangements for exercising the state's ownership rights follow the dual model, where ownership rights are delegated to 38 administrative ministries, each with its own portfolio of CPSEs, while the Department of Public Enterprises serves as the coordinating body and a plethora of other agencies also play important roles. In the predominant view, these arrangements tilt the balance toward overregulation of CPSEs and the involvement of ministries in day-to-day matters and do not allow for the separation of ownership and policy-making functions; these unclear lines of responsibility may also create conflicts of interest. CPSE boards continue to be rooted in the public sector and are not evaluated on their performance. Implementing disclosure requirements is a major challenge for many CPSEs, particularly in light of relatively weak internal audit and control functions, lack of guidance on disclosure for unlisted firms, and potential duplication and delays in the various CPSE audits.

The government of India is continuing its reforms on several fronts: (1) focusing reform efforts on the country's most important companies to improve their performance and delegate to them more power and autonomy, while requiring greater transparency and accountability; and facilitating listing of such companies on the capital markets; (2) strengthening the state's ownership role by focusing the role of line ministries on policy making and limiting their day-to-day involvement in commercial decision making, while giving boards greater decision-making powers in practice; improving the ways in which the government exercises its key ownership functions, such as enhancing transparency in the board appointment process and further refining the MOU system to make it more effective; enhancing the role and capacity of the Department of Public Enterprises to make it a more active promoter of the governance agenda; and focusing on the implementation of the corporate governance guidelines to make them more effective in promoting and monitoring compliance; (3) professionalizing CPSE boards by bringing in independent directors from the private sector; empowering boards with even greater decision-making authority; ensuring fair and responsible behavior through integrity and accountability mechanisms; strengthening audit committees; introducing

(box continues on next page) 
BOX 9.1 continued

performance-based board evaluation and remuneration practices; and making board development and leadership programs mandatory; and (4) enhancing transparency and disclosure by further improving company reporting, strengthening internal auditing, and streamlining the audit system to avoid duplication and ensure timeliness.

In addition, the Second Pay Committee Report recognizes the need to modernize human resource policies to increase CPSE competitiveness. It has proposed a market basis for CPSE compensation, taking into account the need for flexibility between companies while still maintaining appropriate oversight and developing robust performance evaluation systems. A number of recommendations are under consideration, including greater flexibility in pay to narrow the gap with the private sector; greater use of performance-based pay; and developing and implementing performance evaluation and benchmarking systems for companies.

Source: World Bank 2010.

Building the capacity within government and within SOEs to meet data requirements is an important starting point. Not only is this process essential for diagnosing and starting reforms, but it is also a less contentious process and can help build capacity and ownership for reforms. Prioritizing data gathering can benefit the internal governance of the SOEs since it drives capacity development within the SOEs and can lead to better internal information for management and the board of directors. Governments can assist in the process by streamlining data requirements, organizing the information in a consistent format, and reporting these data to a centralized collection point. Many countries have invested in automation of the data and have developed technological solutions for publicly disseminating them.

\section{Phasing or Sequencing Reforms on the Basis of Their Political and Institutional Feasibility}

Phasing, which is important in addressing entrenched interests, can also serve to prove the concept of governance reform and give policy makers the confidence to take further steps. The essence of good governance structures is for SOEs to operate with reasonable autonomy, backed up by highly professional boards and management and the discipline of strong oversight 
and performance management. Because SOEs are often such poor performers, it is difficult to argue for more autonomy. In such a situation, however, incremental change is frequently more likely to succeed, showing politicians and policy makers that excessive interference in the affairs of SOEs is more often the cause of problems than the solution.

When opposition to more difficult reforms such as development of SOE laws and centralization of ownership functions is strong, other options can be considered. One option is to start with actions that are not particularly controversial-for example, increasing the competencies of SOE boards by phasing in independent directors from the private sector; providing training for board members; developing a performance-monitoring framework; and monitoring SOE disclosure. Where local corporate governance standards are reasonably strong and there are stock exchanges, another option is to list SOEs on the stock market. In addition to improving transparency and changing firm behavior, listings have the additional benefits of bringing companies under private frameworks and thereby changing their management and governance. Mixed ownership through listing of shares on the stock exchange can be an effective means for disciplining SOEs and improving their governance through disclosure and the adoption of private sector practices. The more difficult reforms that require time and a change in mind-set could be phased if and when the other reforms take hold and create pressures for more extensive changes.

Many countries have successfully adopted a more centralized approach to the ownership function, resulting in specialization of skills, consistency in governance approaches, streamlining of processes, and aggregation of data. However, more than other reforms, centralization can run into political and institutional resistance because of the potential loss of control by other arms of government. In the face of such resistance, an incremental approach that builds on existing arrangements may be wise (box 9.2). For instance, establishing a support unit in key ministries, such as finance, while line ministries focus on core ownership functions, can be a precursor to later centralization.

\section{Supporting Company-Level Improvements}

In countries with large SOE sectors, improving corporate governance of the sector as a whole can be daunting and time consuming. An option in such cases is to focus on a few specific companies, or specific ministries, to build momentum and demonstrate concrete results. These could include large and visible SOEs that are of strategic importance to the economy or of greatest risk to financial stability and soundness. Focusing on a few important 
BOX 9.2

\section{Strengthening SOE Oversight and Transparency in Paraguay, 2008-13}

State-owned enterprises have played a significant role in the Paraguayan economy, accounting for roughly 10 percent of GDP or 30 percent of the country's public expenditure. Even though profitable as a sector, the contingent liabilities of SOEs for the state totaled 6 percent of GDP. Although SOEs provided essential goods and services-including petroleum, water, telecommunications, and electricity-their service delivery and management performance were limited.

To a large extent, their mediocre performance was due to the institutional limitations that prevailed until 2008. In particular, before the reform process the responsibilities of the different government actors overseeing SOEs were fragmented, leading to overlapping functions and authority. Also, the information on the performance and fiscal situation of SOEs was asymmetric between their management on the one hand and government and civil society on the other. Finally, comprehensive financial information on SOEs was not publicly available, which greatly undermined effective state oversight, strategic planning, and decision making.

In 2008, Paraguay responded by significantly strengthening oversight of SOEs while building on the existing institutional structures. A key part of the reform was to increase interministerial coordination by establishing an SOE Council under the leadership of the presidency comprised of the Ministry of Finance, the Ministry of Public Works, and the Ministry of Industry and Trade, and the attorney general. The objective of this council was to act as the shareholder of SOEs on behalf of the government and to supervise SOEs' corporate governance, financial management, and business management. At the technical level, the council was supported by an SOE Monitoring Unit to undertake effective information analysis and business monitoring of SOEs. Staff members of this unit are qualified, professional, and highly motivated. One or two persons were assigned to closely monitor each SOE and develop technical knowledge and thus became specialists in their assigned sectors. Staff of the unit received extensive training in financial analysis, procurement, management, negotiation, strategic planning, and comparative experiences in SOE oversight from other countries.

The SOE Council meets once or twice every week to receive technical inputs from the SOE-Monitoring entity. A quarterly SOE 
BOX 9.2 continued

performance report is presented to the president of the republic, who in turn holds a meeting with SOE presidents to discuss the performance of each SOE. This practice has resulted in heightened visibility of SOE performance and increased accountability for SOE management. Later steps made budgetary allocations to SOEs more rational, to reduce the outstanding debt of government units for basic services provided by SOEs (such as water, electricity, and phone services) and to ensure more regular payments to SOEs. Combining the council's fast interinstitutional decision-making capacity with the professionalized SOE Monitoring Unit created a responsive and technically sound SOE supervisory framework.

As part of the reforms, Paraguay's interministerial SOE council required SOEs to hire independent professional audit firms, to submit the financial reports to the SOE Monitoring Unit, and to subsequently publish the audits. The oversight body also established an audit follow-up mechanism, which included field visits, letters highlighting the main findings and recommendations of the audits, and, if needed, a warning report to the minister of finance to discuss the content during the next SOE Council meeting. Following the reforms, SOEs published audit reports all within six months after the closing of the fiscal year. These measures helped increase the SOEs' financial management soundness and provided a venue for civil society and the media to exert additional oversight of SOEs. For instance, the 2010 audit of the oil company PETROPAR showed that the company had two times more liabilities than assets, mostly because of payment arrears to foreign suppliers and a debt to foreign suppliers amounting to 1.9 percent of GDP. With the progressive adoption of the practice and follow-up activities of the oversight body, it is expected that the timeliness and quality of audit reports will continue to improve. The objective is to make SOEs' audited financial statements available no later than June 30 of the following year. Audited financial statements of SOEs are published on the Ministry of Finance's website: http://www.hacienda.gov.py/web-sseei_vl/index.php?c=322.

SOEs leads to higher performance and greater transparency. These tangible improvements could create momentum for more widespread implementation of reforms across all SOEs.

If the government introduces formal policy reforms, SOE boards must ensure that governance reforms are implemented effectively within the 
enterprise. However, in the absence of formal reforms, SOE boards themselves still may have the freedom to promote corporate governance improvements. In either case, the board could proceed by first assessing its current corporate governance practices and developing an improvement plan. Annex 9A provides a tool for helping companies in this regard. Once the plan is in place, committing the SOE to strengthening its governance is a critical factor for success. Annex 9A provides a progression matrix for evaluating a company's commitment to corporate governance.

\section{Building Institutional Capacity to Manage and Sustain the Reform Process}

Building and strengthening capacity at all levels are essential to the reform process. Owners, regulators, boards, and senior management will need a solid understanding of corporate governance generally, as well as from their individual perspectives. To remain steadfast in promoting good corporate governance, ownership units will need people with knowledge, skills, and business experience, and in cases where these cannot be recruited or seconded, they will have to be created through training and exposure to development programs in corporate finance and economics. In low-capacity countries, significant technical assistance will be required in the start-up phase. Companies tooincluding the board, the management, and the staff-will require intensive training and capacity building. Corporate governance requires knowledge and skills that are not present in many SOEs in low-income countries or in countries that are just embarking on corporate governance reforms more broadly. The focus of training and capacity building should be on substance over form and on behavioral changes rather than structures.

\section{Building Support for Reform among Stakeholders and the Public}

SOEs often have a long history and are considered crucial to the institutional fabric of a nation's economy. For that reason, SOE reforms are often seen as a precursor to privatization and can accordingly provoke public skepticism about the value of reform. Conversely, where SOEs operate inefficiently, waste and mismanagement can motivate a public debate about the benefits of reform. In this context, communicating the objectives of good governance and the potential for positive outcomes can increase stakeholders' support and influence opinions, attitudes, and behavioral changes. Using their unique 
position, centralized ownership units can advocate change and document its benefits. Aggregate ownership reports, such as performance scorecards and benchmarking reports, can reinforce the arguments for reform and also track progress.

Opponents of change (within government) are often quite concerned about the impact of reform on their capacity to use SOEs for noncommercial purposes. From a pragmatic perspective, it is therefore important to make clear that reforms do not necessarily have to interfere with government's use of SOEs for meeting policy objectives. A reform program, for instance, should not constrain government from continuing to impose public service obligations on SOEs. Instead, it should focus on defining and communicating such obligations to SOEs consistently and transparently and on monitoring SOEs to ensure delivery. A step-by-step approach to negotiating, funding, and monitoring public service obligations can help prove the concept to policy makers; ideally, it will show both line ministries and ministers that a structured process for negotiating public service obligations is more, rather than less, likely to deliver the desired policy outcomes than an ad hoc process.

\section{Improving Corporate Governance as Part of Wider SOE Reforms}

Reforms by themselves will not solve SOEs' problems, however. Past reforms of state enterprise sectors went from one extreme to another, based in part on ideology and in part on "best practice." At first, the focus was exclusively on reforming SOEs (in the 1970s and 1980s) and then on privatizing them (in the 1990s and early-to-mid-2000s). Lessons from these experiences suggest that a comprehensive approach is important.

Reformers should not see governance as a substitute for other reforms such as SOE restructuring and privatization, nor should the success of such reforms be ignored. Reformers should first analyze the SOE portfolio as a whole and then classify individual enterprises according to whether the government intends to keep them for strategic or other reasons, whether the enterprise can and should be privatized, whether those that need restructuring should be merged or consolidated, and whether nonviable enterprises should be liquidated. "Right sizing" the SOE sector can lead to much progress. Substantial evidence suggests that privatization and publicprivate partnerships have brought SOEs big gains in both competitive and noncompetitive sectors. When privatization is not a preferred policy option, SOEs can still be exposed to capital market discipline through private debt financing. Treasuries should seek to step back as a source of debt funding 
and instead encourage SOEs to borrow on their own terms. Requiring SOEs to find a stand-alone credit rating will often cause an enterprise to focus attention on its governance weaknesses. Similarly, public offering of listed corporate debt will usually expose SOEs to significant governance requirements and yet allow the state to retain full ownership.

Other reforms should also be carried out in parallel. This effort involves opening sectors to competition where appropriate and increasing competition in sheltered sectors: SOEs tend to dominate in infrastructure sectors, which can have elements of both created and natural monopolies. Opening sectors to competition can help drive the reform process by incentivizing SOEs to improve their performance. However, it is also likely that governance reform will be a necessary prerequisite to industry restructuring, since without it, it is unlikely that old-school SOEs would have the tools, structures, or mind-set to compete in an open market. As a result, industry restructuring often comes about as a related reform to SOE governance changes.

Governments should also continue to develop the private sector. Establishing market incentives, in particular exposing SOEs to competition, will help sustain reforms in the long term. These incentives will normally require developing coherent sector policies that promote private sector participation, removing entry barriers, creating the appropriate legal and regulatory environment for private investment (including removing regulatory functions from SOEs), and establishing or reinforcing independent regulators. Countries can derive big productivity gains by reconsidering the list of "strategic" and "basic" or "pillar" industries when it is not obvious why state ownership is essential and opening up such sectors to private investment and private participation. 


\section{Annex 9A. Corporate Governance Assessment Tool for SOEs'}

An SOE board that decides to carry out corporate governance reforms might first assess its current corporate governance structures and develop an improvement plan. Based on the corporate governance methodology used by the International Finance Corporation for assessing corporate governance in its own investment transactions, the six key steps below outline how an SOE board can better understand its corporate governance:

- Summarize first impressions

- Conduct a self-assessment

- Perform a corporate governance review

- Set up a corporate governance improvement program

- Document the plan and implement the program

- Establish a supervisory system

These assessment steps may be applied independently by an SOE board or in cooperation with the ownership entity or another third party. The steps are presented here as suggestions. The key is to raise the awareness of the board and of the SOE owner of possible corporate governance issues and to have them gain a complete understanding of the governance challenges facing the SOE, develop a plan to address those challenges, and then implement and maintain the plan, updating it as needed.

Step 1: Develop a first impression of the effectiveness of the SOE's governance policies and practices. A snapshot of the SOE's current corporate governance will highlight what needs to be done and establish priorities. The board, the owner, and their partners should take specific actions to start the process:

- Identify the governance features that contribute to the SOE's performance problems.

- Form an initial view of where corporate governance poses a risk to the enterprise and where reform would likely produce a benefit.

- Set priorities.

Step 2: Undertake a self-assessment. To help build buy-in and understanding of the reform effort and pave the way for further progress, the board and management should conduct an initial self-assessment:

- Start a dialogue among board members and managers on potential areas of improvement. 
- Informally assess the corporate governance framework and practices.

- Focus less on critiquing weak practices than on developing ways to improve existing practices.

Step 3: Undertake a formal corporate governance review. The SOE board should next undertake a more formal corporate governance assessment, either as a continuation of the self-assessment or through collaboration with outside professionals. The progression matrix (Annex 9A) can help set benchmarks for the assessment. Key steps include the following:

- Consider the need for an outside assessor or other professional to assist in the assessment.

- Conduct a corporate governance review and assessment using commonly accepted benchmarks.

- Review both the practice of the SOE and the relevant legal and policy requirements.

- Based on this review and assessment, develop a set of recommendations.

Step 4: Develop a corporate governance improvement program. Alongside the review, outside assistance can be useful in developing an action plan. The plan should focus on what can be done within the specific SOE, but it could also include suggestions for wider changes to the SOE governance framework or changes to the SOE's legal status (including corporatization or listing). Developing the improvement plan includes several important components:

- Drafting a corporate governance action plan, tailored to the SOE with an emphasis on actionable and realistic goals.

- Weighing the need for broader policy changes or changes in the status of the SOE.

- Identifying areas where outside help-from the ownership entity, professional advisers, or technical assistance providers-would be useful.

- Including a timetable and implementation methods.

Step 5: Document and implement the plan. Implementing the plan is, of course, crucial. It starts with preparing relevant documentation. This might include incorporating the plan in a performance agreement with the ownership entity, changing the SOE's articles, or taking other steps. When implementing the plan, the board and ownership entity should:

- Embed the action plan in relevant documents (such as a performance agreement), in the SOE's objectives and in other documents and policies. 
- Ensure that the board has the authority to implement the plan and has the support of the ownership entity.

- Assign implementation of appropriate recommendations to the board, management, and, if need be, the owners.

- Seek additional help for implementation and make corrections as needed.

- Where necessary, provide board training on corporate governance to ensure a proper understanding of the policies and procedures.

- Communicate effectively with the SOE's employees and other stakeholders.

Step 6: Supervise implementation and review progress. As the plan is being implemented, progress needs to be regularly reviewed and communicated. The plan may need to be revised or extended to ensure that corporate governance improves and that the momentum for reform is maintained. The following steps are critical:

- Ensure that processes and procedures are properly implemented and periodically reviewed.

- Regularly assess outcomes.

- Consider creating a standing committee or a working group of the board to regularly review governance issues.

- Work to communicate success to stakeholders and to set an example for other SOEs and companies.

- Be alert to corporate governance challenges emerging in the SOE or from the state.

- Keep abreast of wider corporate governance developments and take these into account to maintain the momentum for reform. 
ANNEX 9A IFC-World Bank Progression Matrix for SOEs: Commitment to Corporate Governance

\begin{tabular}{|c|c|c|c|}
\hline $\begin{array}{l}\text { Level 1: Acceptable } \\
\text { corporate governance } \\
\text { practices }\end{array}$ & $\begin{array}{l}\text { Level 2: Extra steps to } \\
\text { ensure good corporate } \\
\text { governance }\end{array}$ & $\begin{array}{l}\text { Level 3: Major contribution } \\
\text { to improving corporate } \\
\text { governance nationally }\end{array}$ & Level 4: Leadership \\
\hline $\begin{array}{l}\text { - The SOE has stated } \\
\text { its intention to } \\
\text { improve its corporate } \\
\text { governance practices. } \\
\text { - The SOE has a legal } \\
\text { status distinct from } \\
\text { the government. }\end{array}$ & $\begin{array}{l}\text { - The SOE uses } \\
\text { documented policies, } \\
\text { including on } \\
\text { governance and } \\
\text { ethics, and has a } \\
\text { program to improve } \\
\text { governance. } \\
\text { - The SOE is } \\
\text { corporatized. } \\
\text { - The SOE has access } \\
\text { to outside finance. } \\
\text { - The SOE's public } \\
\text { service and policy } \\
\text { obligations are well } \\
\text { understood. }\end{array}$ & $\begin{array}{l}\text { - The SOE discloses its } \\
\text { compliance with a } \\
\text { national code of } \\
\text { governance. } \\
\text { - The SOE is incorporated } \\
\text { under company law. } \\
\text { - The financing and nature } \\
\text { of the SOE's public } \\
\text { service and policy } \\
\text { obligations are } \\
\text { transparent. }\end{array}$ & $\begin{array}{l}\text { - The SOE has adopted } \\
\text { corporate governance } \\
\text { practices that are } \\
\text { consistent with } \\
\text { international good } \\
\text { practice. } \\
\text { - The SOE has issued } \\
\text { securities and meets } \\
\text { listing requirements. } \\
\text { - The SOE's public } \\
\text { service and policy } \\
\text { obligations are fully } \\
\text { compatible with its } \\
\text { commercial } \\
\text { orientation. }\end{array}$ \\
\hline
\end{tabular}

\section{Note}

1. Adapted from the Corporate Governance Development Framework of the IFC.

\section{References}

OECD, 2005, OECD Guidelines on Corporate Governance of State-Owned Enterprises. Paris: OECD.

- 2012. Towards New Arrangements for State Ownership in the Middle East and North Africa. Paris: OECD.

World Bank. 2010. "Corporate Governance of Central Public Enterprises in India." Financial and Private Sector Development Vice Presidency, World Bank, Washington, DC. 


\section{Country-Level Tools: Instruction Sheet}

This instruction sheet describes the two main country-level tools for carrying out a review of the corporate governance framework for state-owned enterprises (SOEs) in a given country. These are designed to assess the strengths and weaknesses of the framework in a particular country. The focus is on SOEs that have a distinct legal form-separate from the public administration-and that engage in a commercial activity, with the bulk of their income coming from sales and fees. The two country-level tools are:

- The country assessment questionnaire. (Appendix B) This tool contains a list of questions and requests for documentation that forms the basis for a corporate governance review of the legal and regulatory framework for the SOE sector as a whole in a given country. The assessment questionnaire is organized along the same lines as the eight main chapters in the toolkit. It seeks to identify:

- The extent of state ownership and the role of SOEs in the economy.

- The main elements of the legal and regulatory framework affecting SOEs.

- The organization of the state's ownership function as distinct from its policy and regulatory functions.

- The performance-monitoring system for SOEs. 
- The financial and fiscal discipline framework for SOEs.

- The structure, functions, and responsibilities of SOE boards.

- The framework for transparency, disclosure, and controls.

- The provisions that offer protection to nonstate shareholders in enterprises in which the state has a significant stake.

The assessment questionnaire can be completed either by the country authorities that have requested the assessment or by consultants who work in close cooperation with the relevant authorities. Users can edit the assessment questionnaire as necessary and tailor it to the local context.

With some questions, it may be easier or more effective to present responses in a table. Legal citations and full references for the source and a date for data and information or comment provided by third parties should be provided. The exchange rate and date when converting local currency into U.S. dollars should be indicated.

- The sample SOE survey instrument. (Appendix C) In many countries, the focus of an SOE assessment is to go beyond an assessment of the legal and regulatory framework and to capture and understand company practices. A sample SOE survey instrument is included for this purpose; it will need to be customized to local circumstances to the maximum extent possible. In particular,

- Information about local circumstances (based on the assessment questionnaire) should be used as an input to develop the survey.

- As part of the customization process, local terminology should be used and the survey instrument should be translated as needed.

- The survey should ideally be sent to SOEs by the country authorities, to increase the response rate and build trust.

- Questions that attempt to capture personal information about the respondent should be avoided.

In carrying out a country-level assessment of SOE corporate governance using the above tools, it is important to:

- Provide clear and concise terms of reference for the assessment, which include the scope of the review, the expectations of the reviewing team and the client country authorities, the deliverables to be produced, and a timeline for completion.

- Clarify the scope of the assessment and the companies and sectors that will be included. Many countries have complex SOE sectors with different owners, legal forms, and governance practices.

- Agree on the goals and expectations for the assessment, To obtain full cooperation in sensitive cases, reviewers should set an appropriate tone for the assessment and avoid portraying the process as an "inspection" or "audit." 
To carry out a thorough assessment of SOE governance, the review team needs to have direct discussions with those who play a variety of SOE governance roles. A standardized list of the institutions that would normally be included in the process is provided below.

- Ministry of finance (including units responsible for monitoring SOEs, if any)

- Centralized ownership unit or state property committee (if any)

- Line ministries responsible for the oversight of significant portfolios of SOEs

- Securities commission

- Stock exchange

- Supreme audit institution

- Private sector audit firms

- Institutes of corporate governance and institutes of directors

- As many meetings as possible with a broad cross-section of SOEs, covering the relevant sectors and ownership structures under review. At each company, it would be most productive to meet with the chairperson and members of the board of directors 



\section{Country-Level Tools: Assessment Questionnaire}

\section{Introduction}

This questionnaire is designed to assess the strengths and weaknesses of the corporate governance of state-owned enterprises (SOEs) in a particular country. The focus is on SOEs that have a distinct legal form, separate from the public administration, and that engage in commercial activity, with the bulk of their income coming from sales and fees.

The questionnaire consists of eight sections:
A. Review of SOE sector
B. Legal and regulatory framework
C. State ownership arrangements
D. Performance-monitoring systems
E. Financial and fiscal discipline
F. Board of directors
G. Transparency, disclosure, and controls
H. Minority shareholder rights. 
The questionnaire may be completed by the relevant government authority(ies) or by a local consultant. When preparing the responses to the questionnaire, the responder should answer all questions as completely as possible. The preparer should seek to provide answers relevant for all SOEs and related government bodies, while drawing distinctions as needed, and for all national SOEs, as well as the subnational levels, where that is covered. The questionnaire can be tailored or edited as necessary to take into account special circumstances that may be present in a country.

With some questions, it may be easier or more effective to present responses in a table. Legal citations, full references for the source, and date for data, information, and comments, and exchange rate details (when converting local currency into U.S. dollars) should be provided.

\section{Glossary of Key Terms}

Board: The term board in this questionnaire refers to the governing body of each SOE. Boards come in many forms around the world, including singletier boards with a combination of executives and nonexecutives and two-tier structures with separate management and supervisory boards. In general, in two-tier systems, board refers to the highest-level body that addresses strategic concerns and is not involved in day-to-day management.

GMS: General meeting of shareholders. A company gathering, at which shareholders and management discuss the previous year and the outlook for the future, directors are elected, and other shareholder concerns are addressed.

Commercial objective: Objectives of the SOE relevant for its commercial performance such as revenue, earnings, market share, and cost of capital.

Coordinating body: A single body set up to coordinate the exercise of the state ownership rights in SOEs and oversee their corporate governance. The coordinating body may coexist with one or more ownership entities.

Ownership entity: The part(s) of the public that exercises the state's ownership rights in an SOE, such as voting in the shareholder meeting, nominating board members, and monitoring performance. A country may have one centralized ownership entity or a decentralized system in which rights are exercised by the line ministries (ministères de tutelle). In some cases, different parts of the administration may share ownership rights in a single SOE. 
Ownership policy: A policy or policies that specify the state's objectives as an owner, for the overall state-owned sector as well as for a particular SOE. The policy can also clarify how SOEs make the required trade-offs when various objectives may come into conflict.

Policy objective: Objectives designed to fulfill certain policy functions relevant for the SOE, such as providing reliable energy supplies, affordable housing, a certain level of employment, and similar noncommercial objectives.

SOE: A commercial enterprise that uses a distinct legal form-separate from the public administration-and engages in a commercial activity and that receives the bulk of its income from sales and fees. 


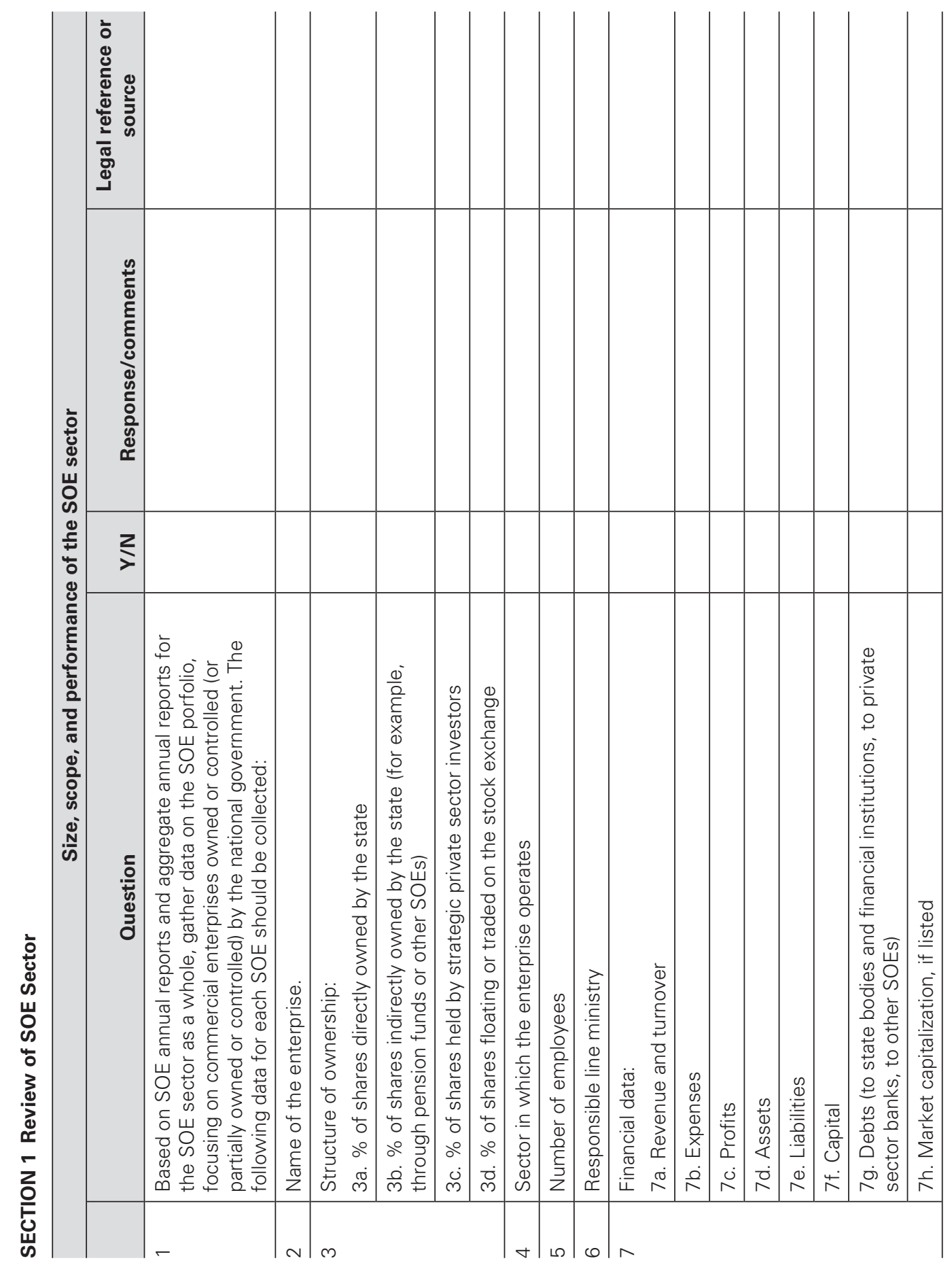




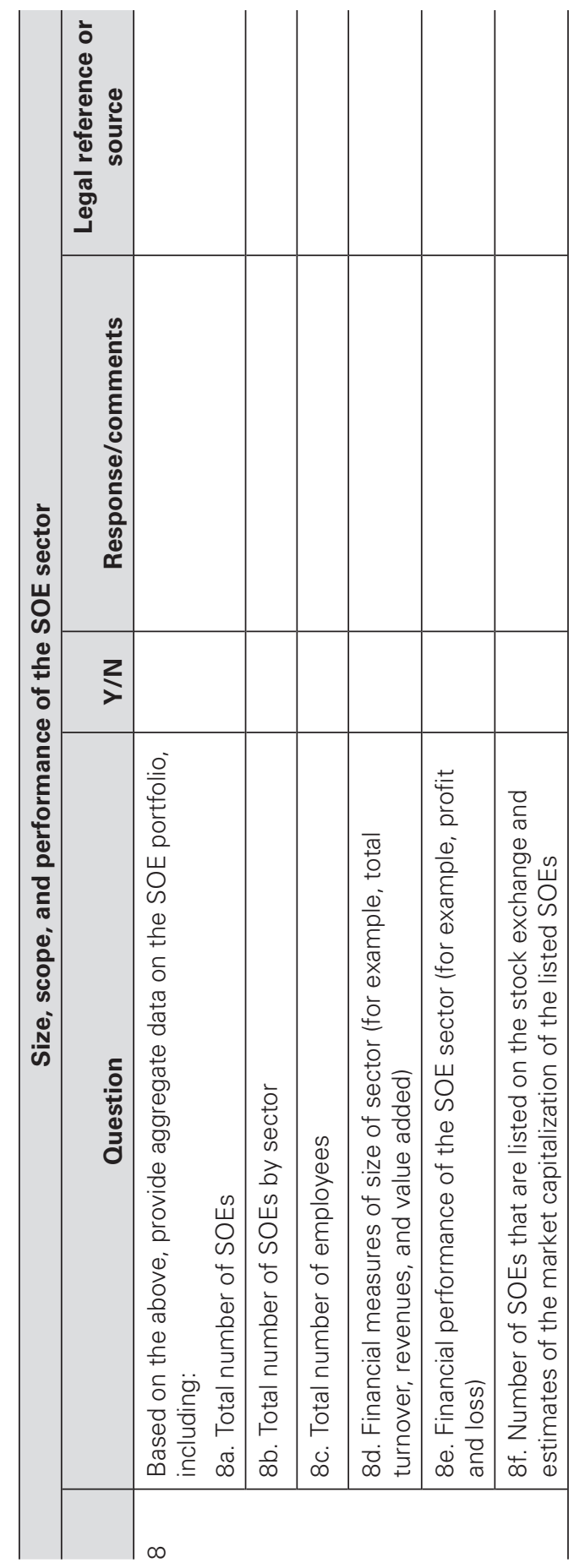




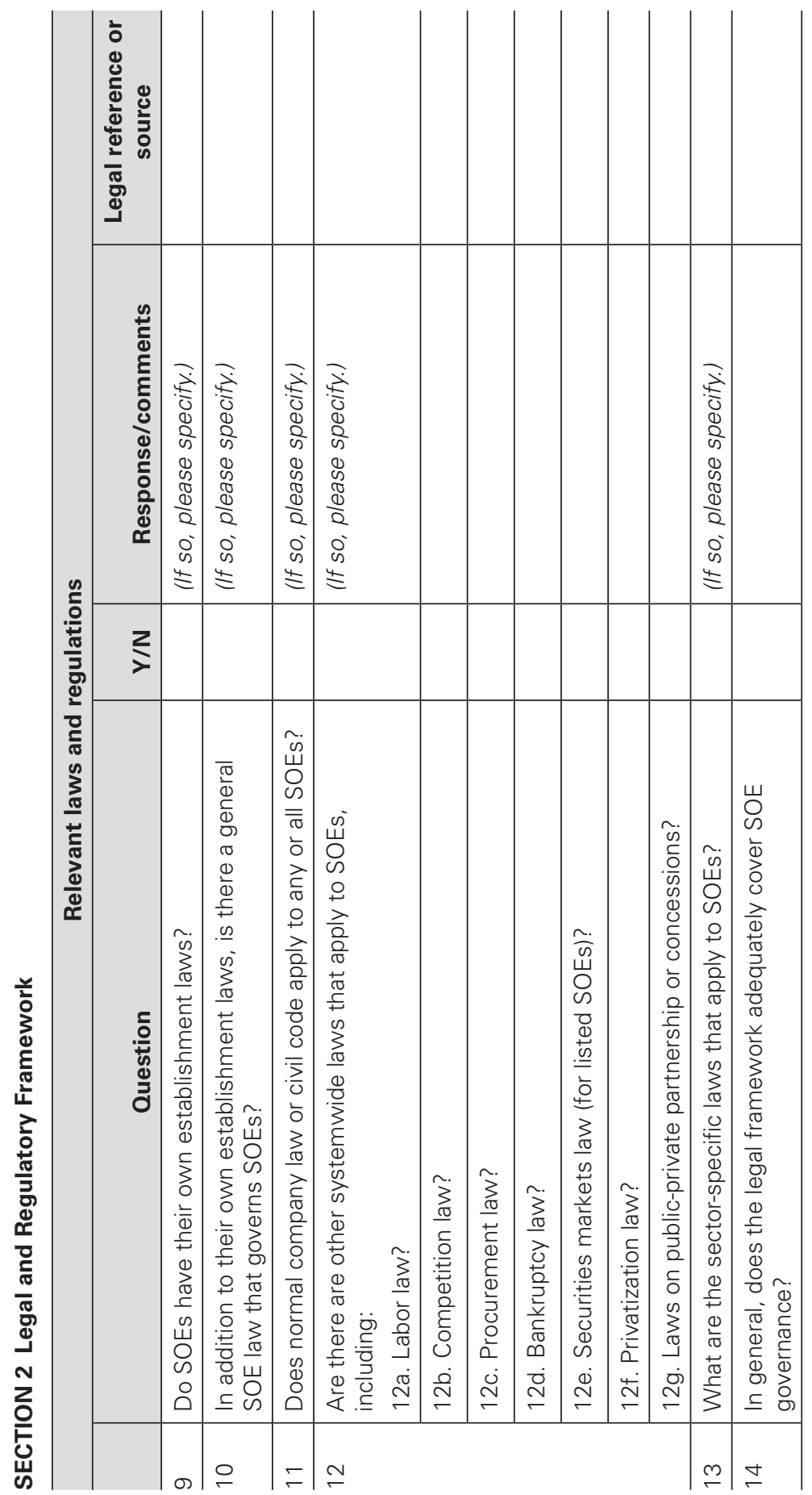




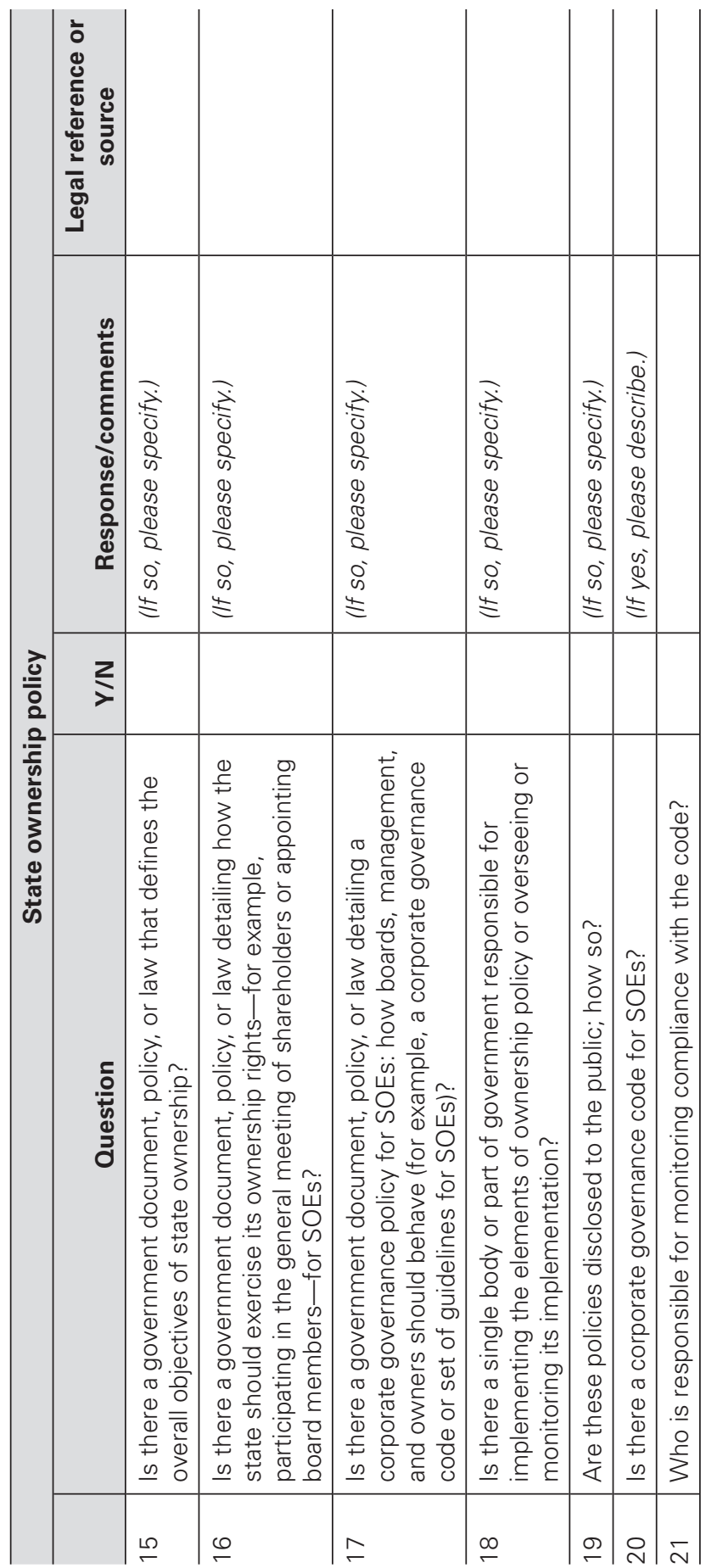



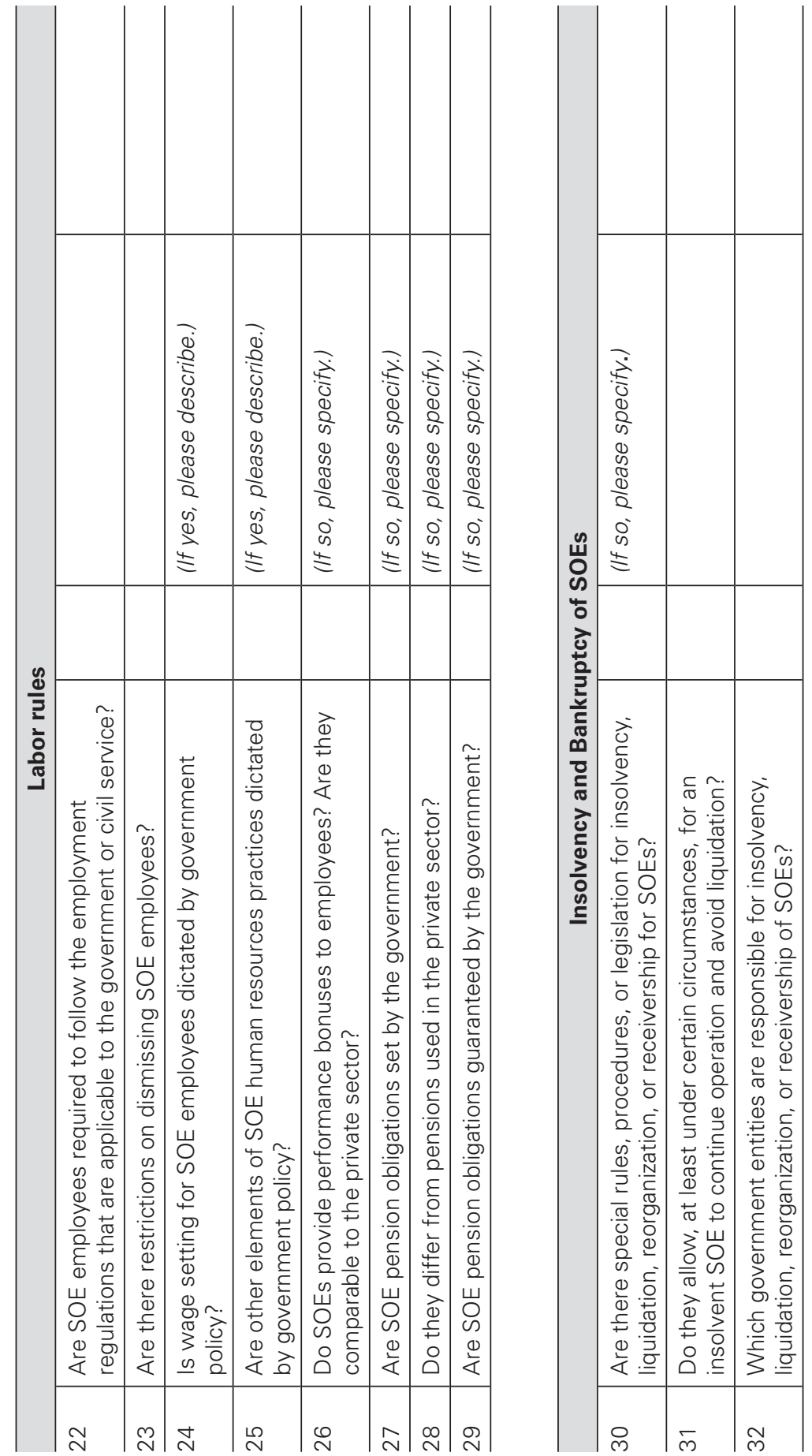


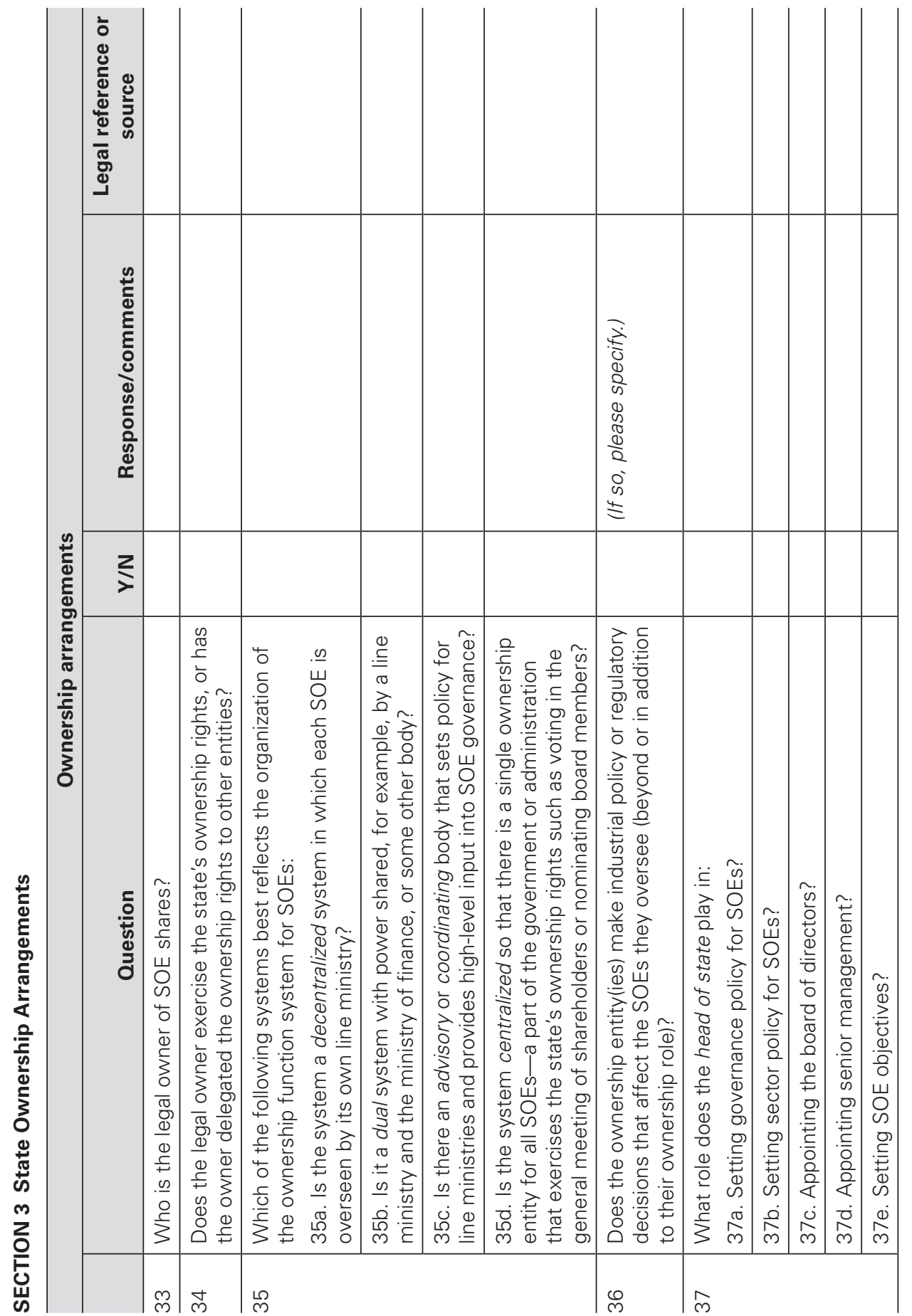




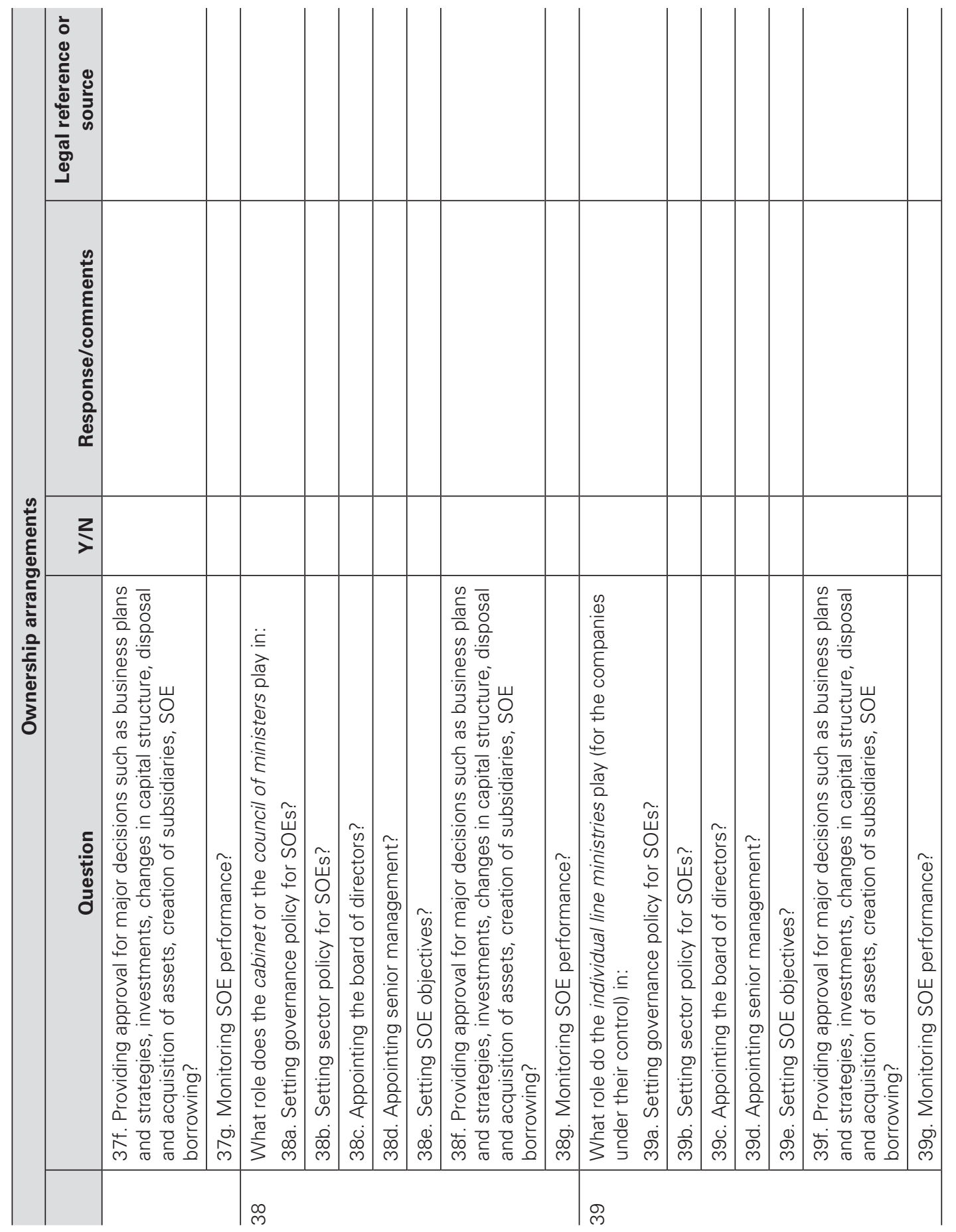




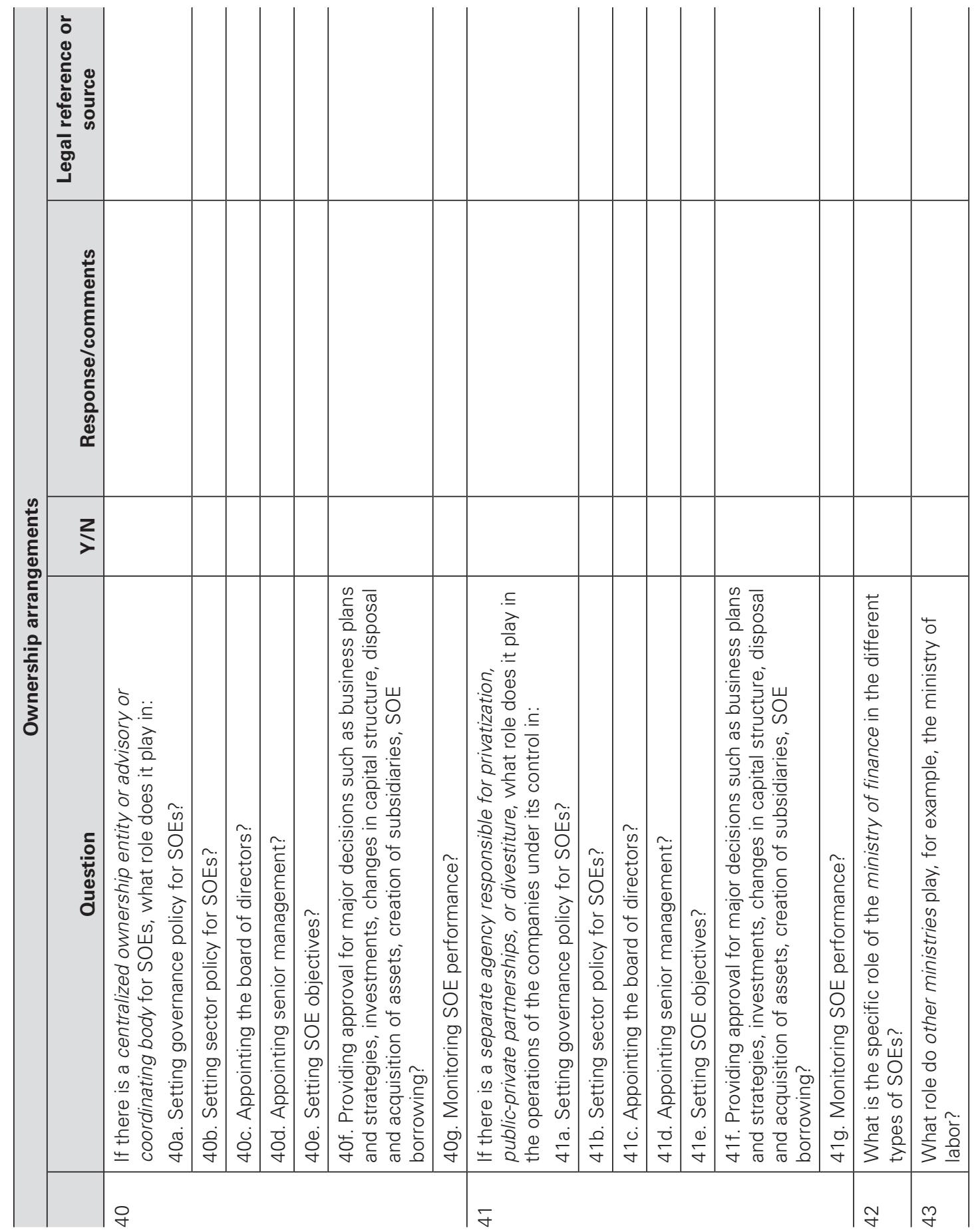




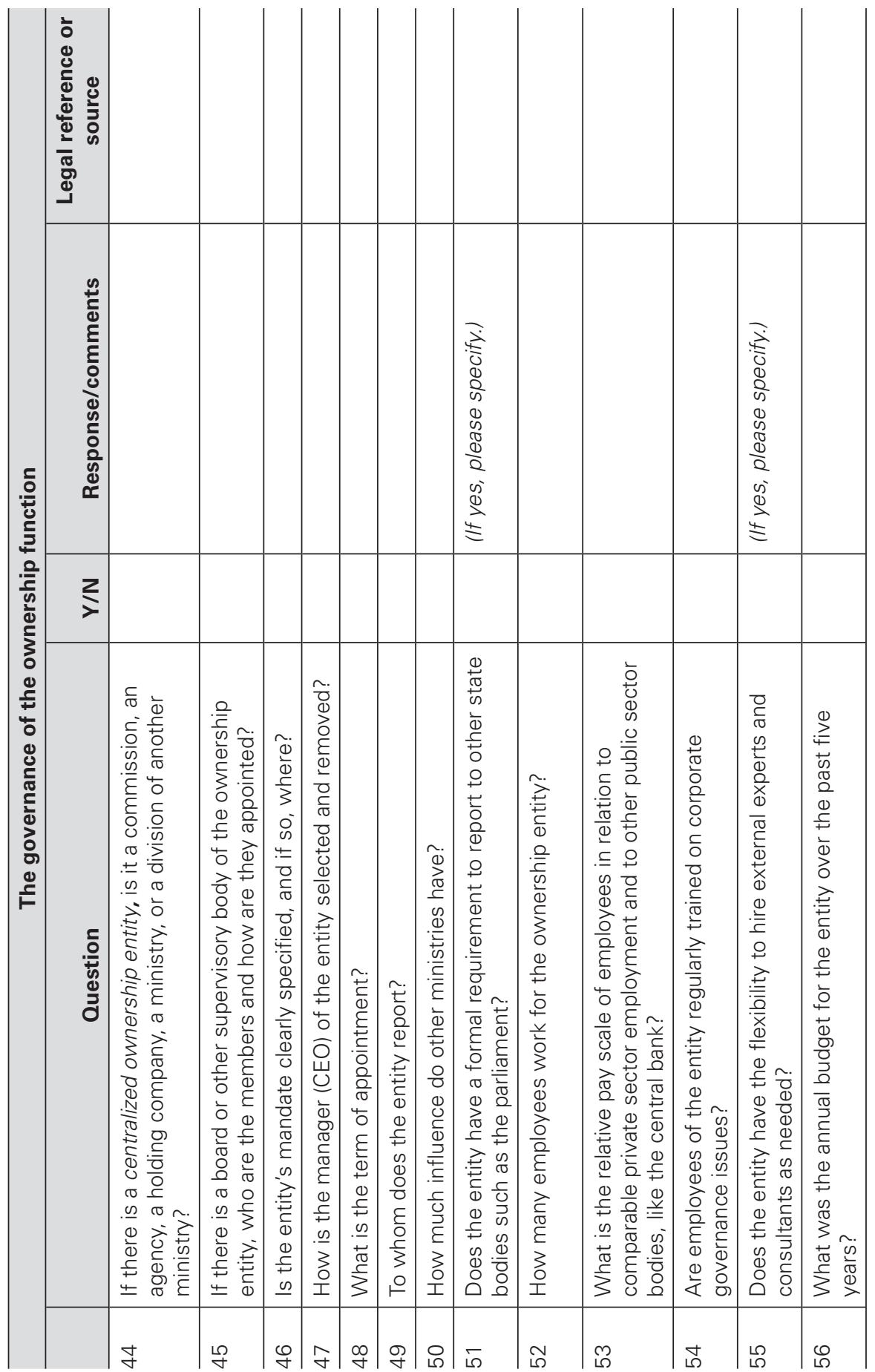



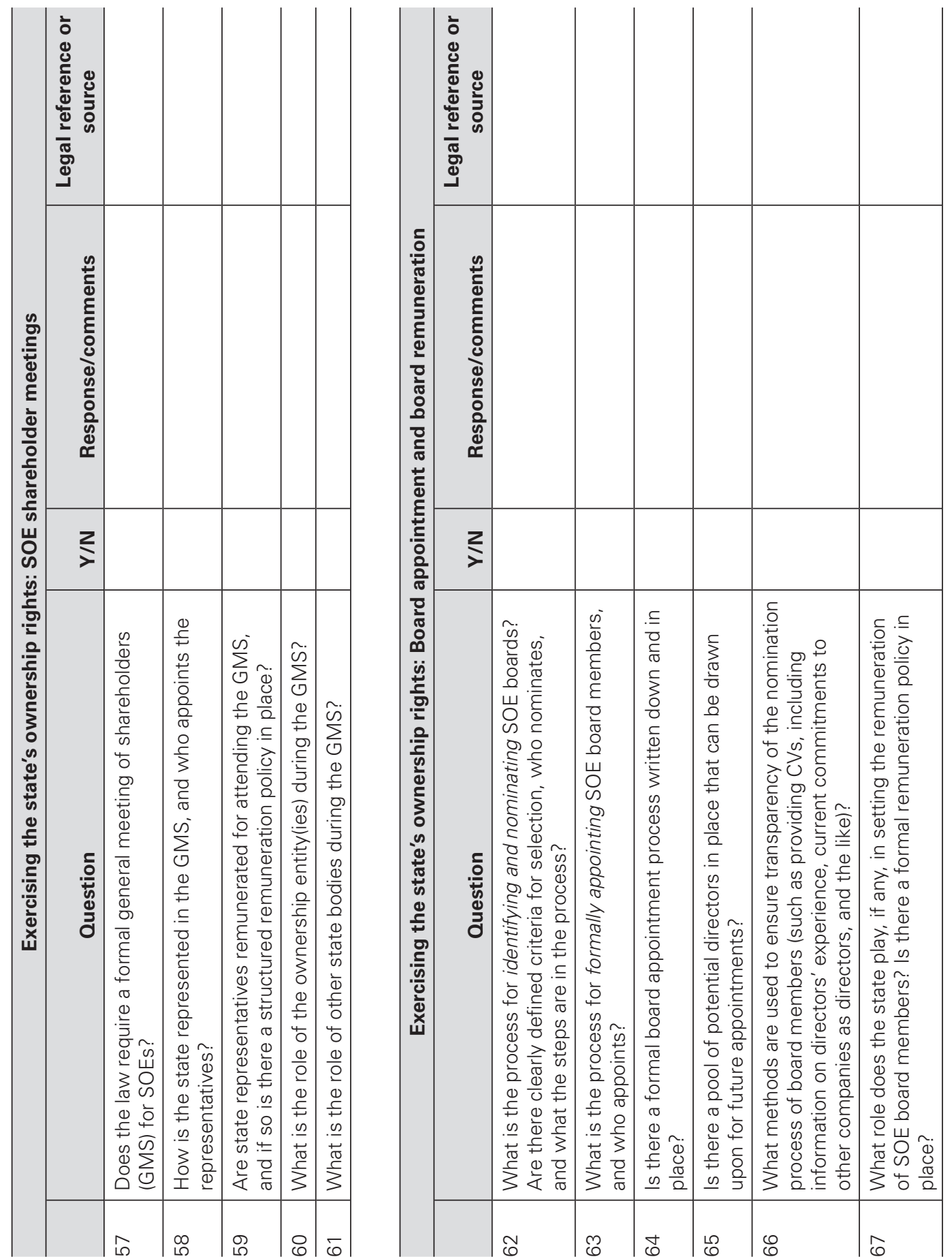


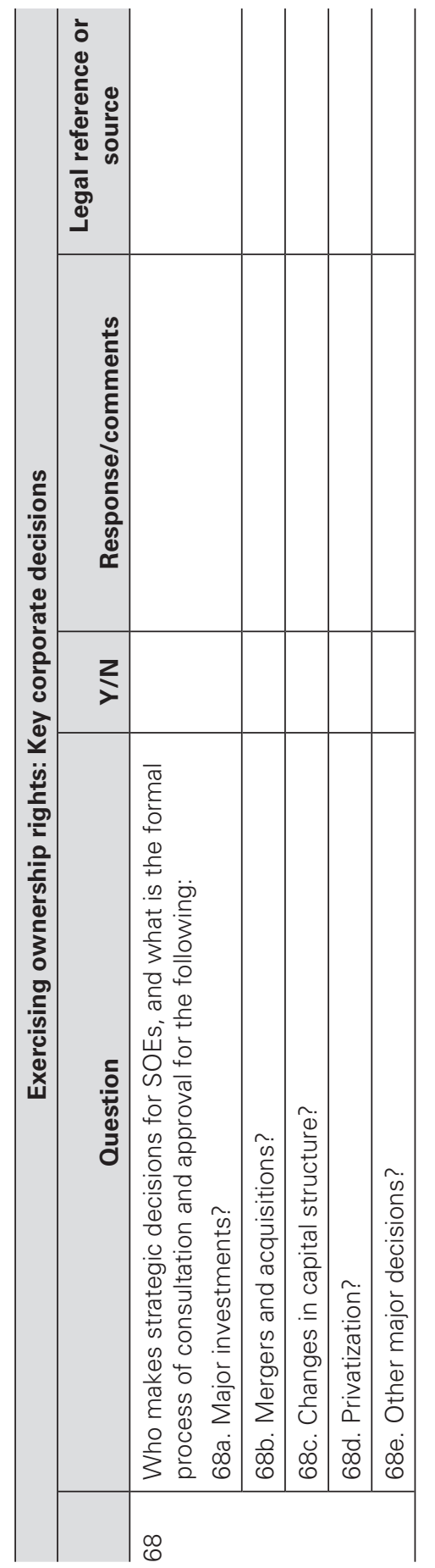




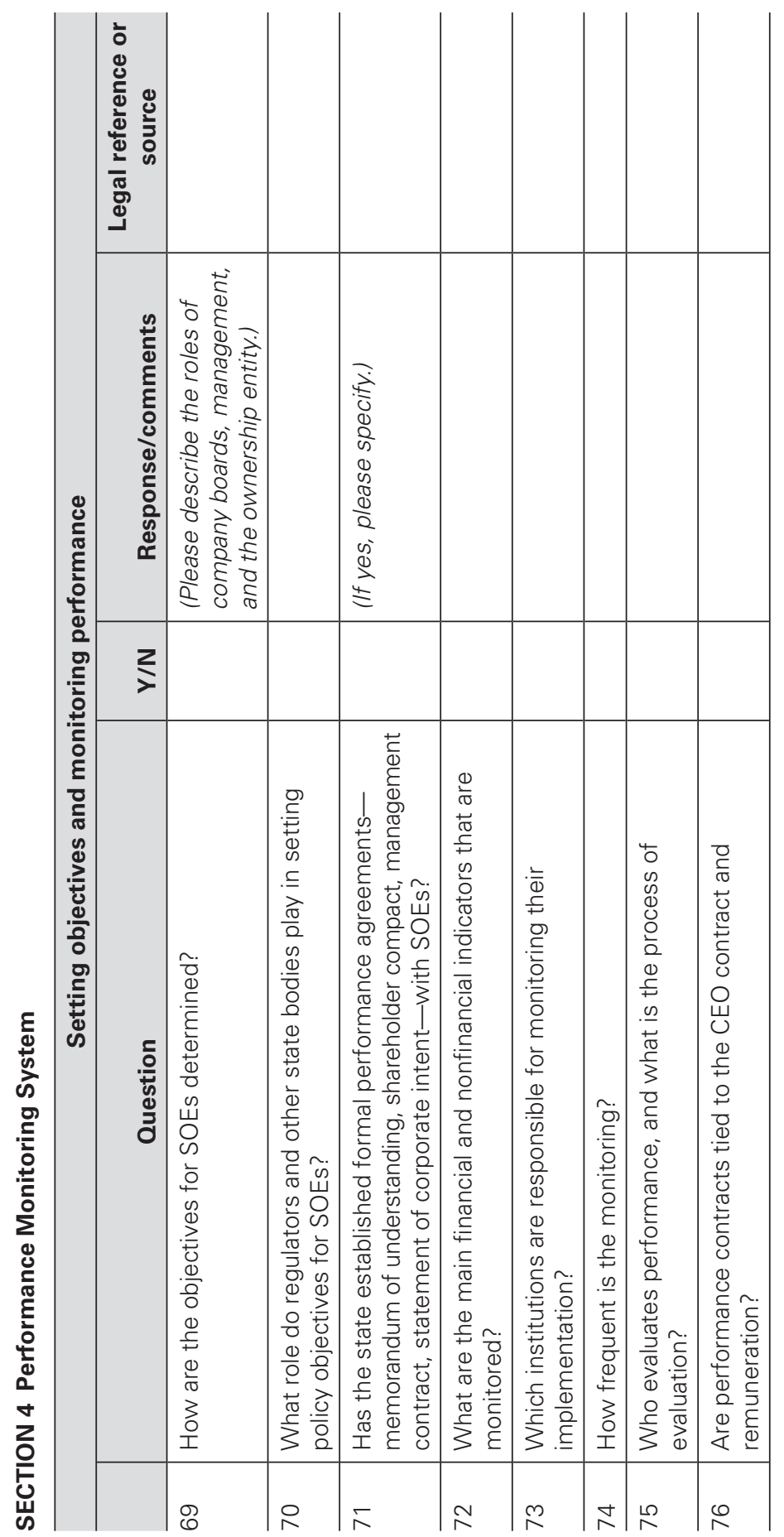




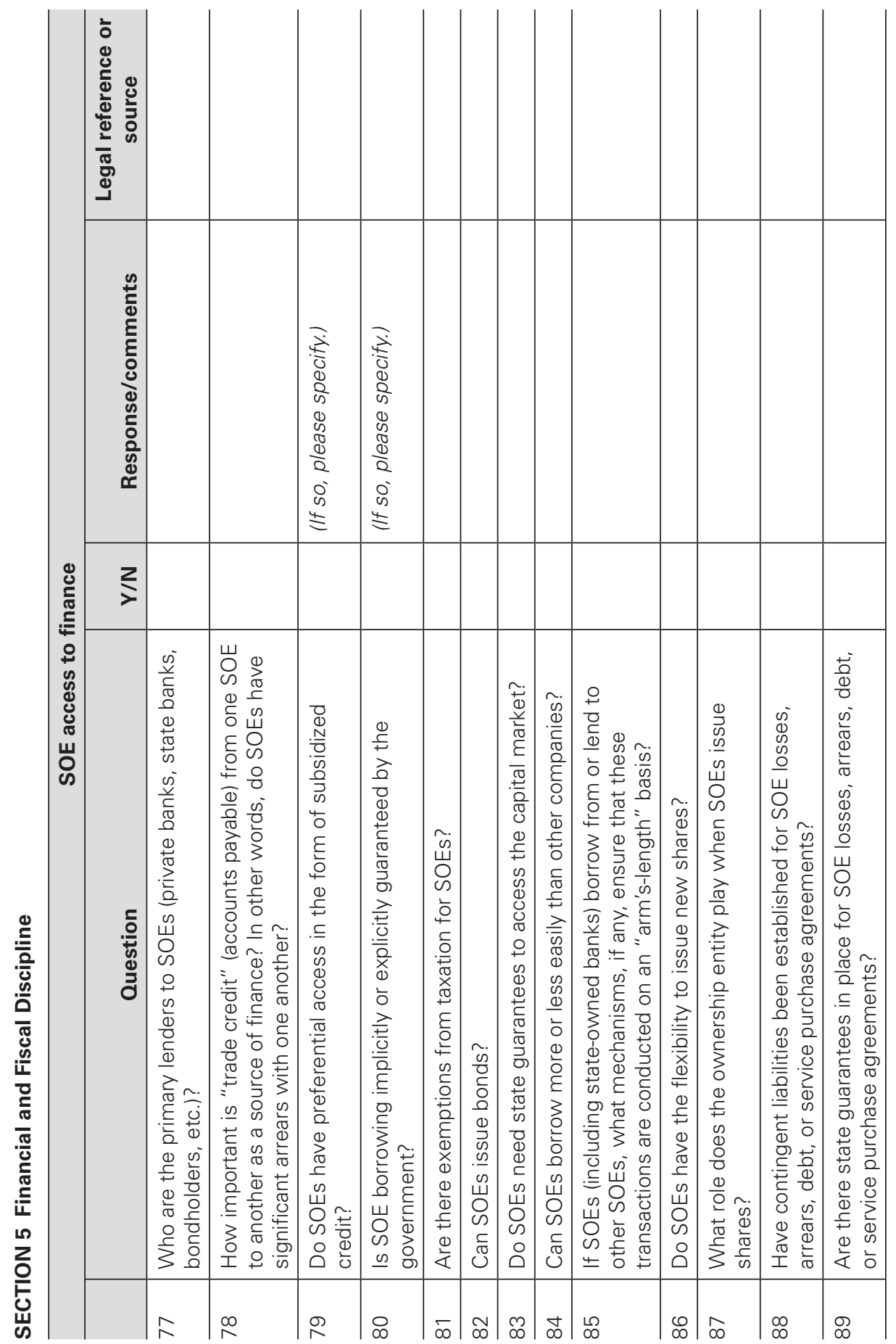




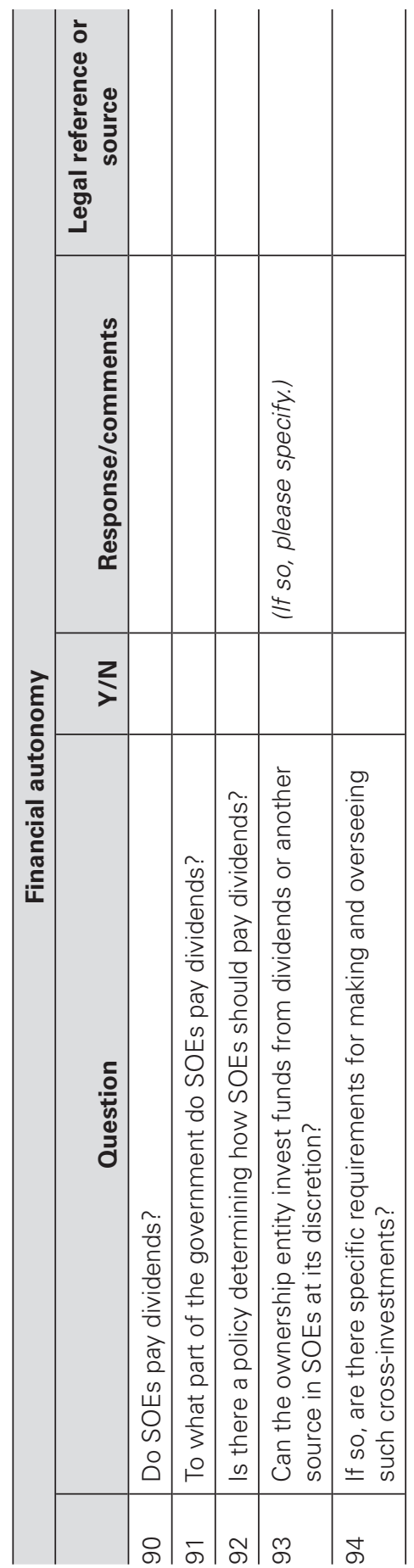




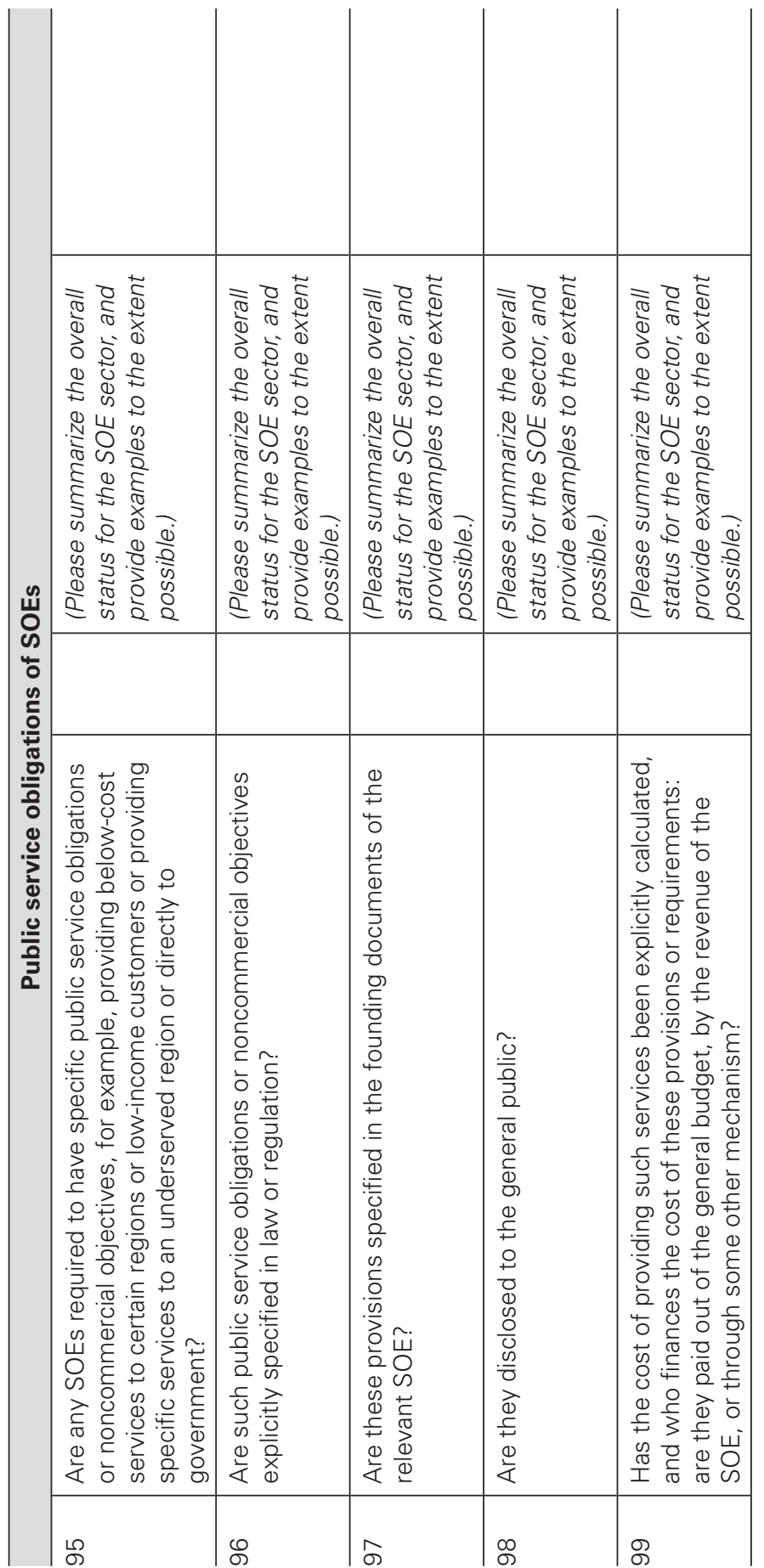




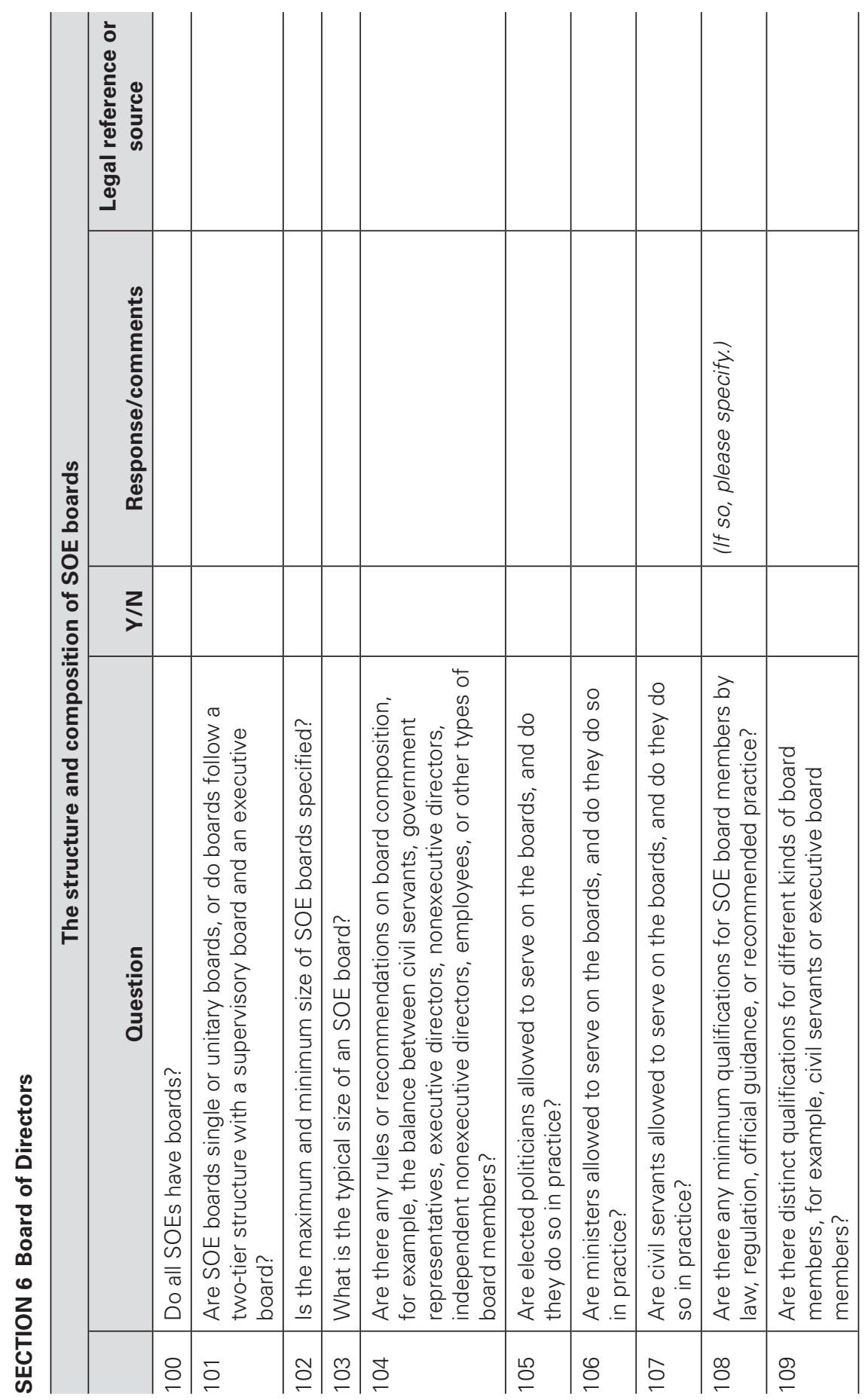




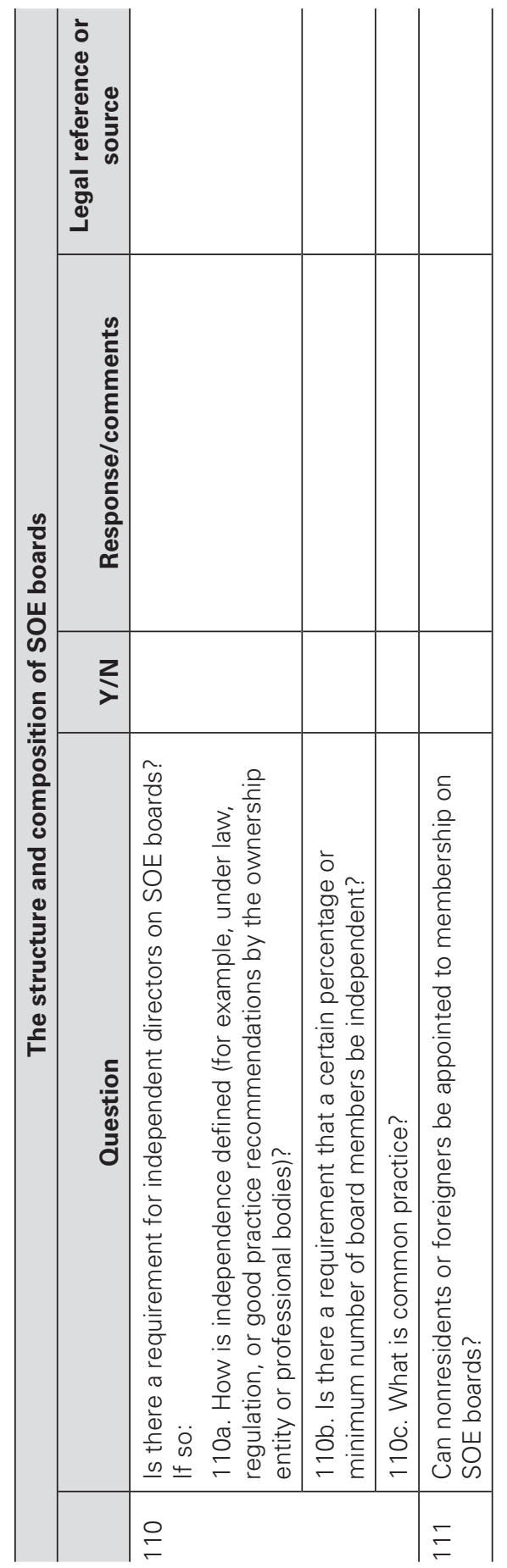




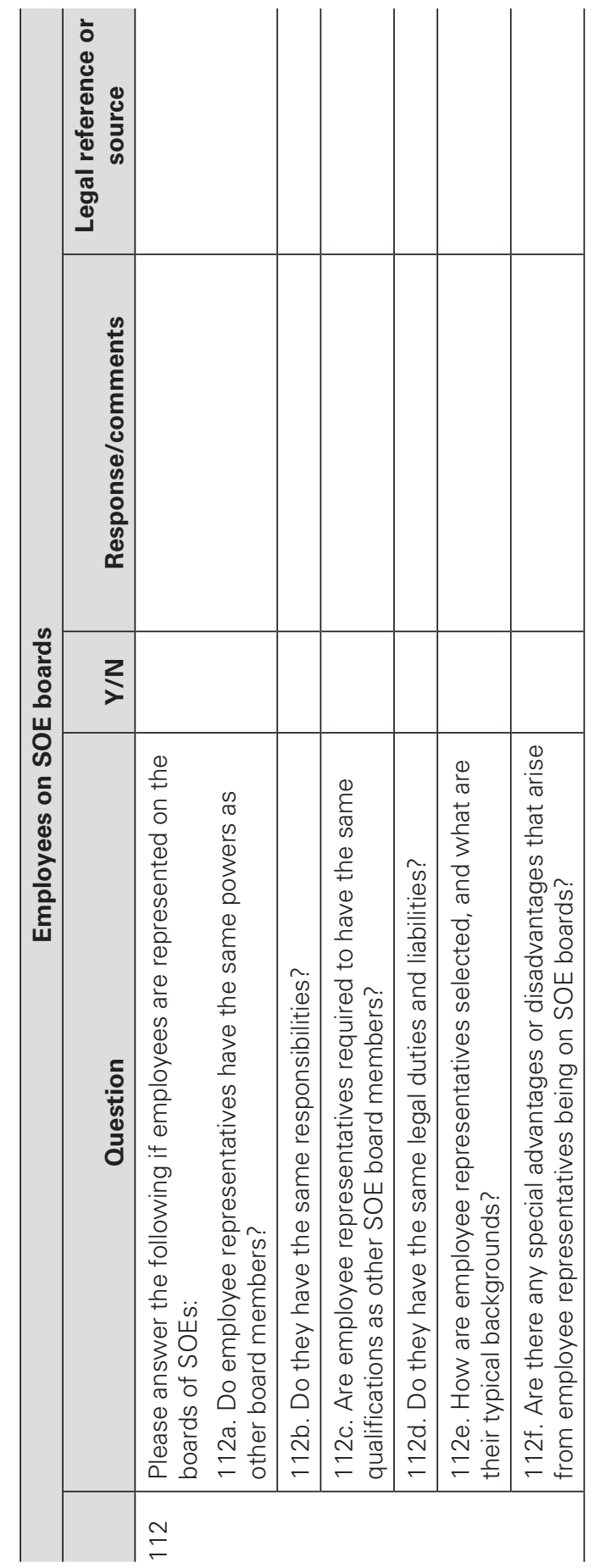




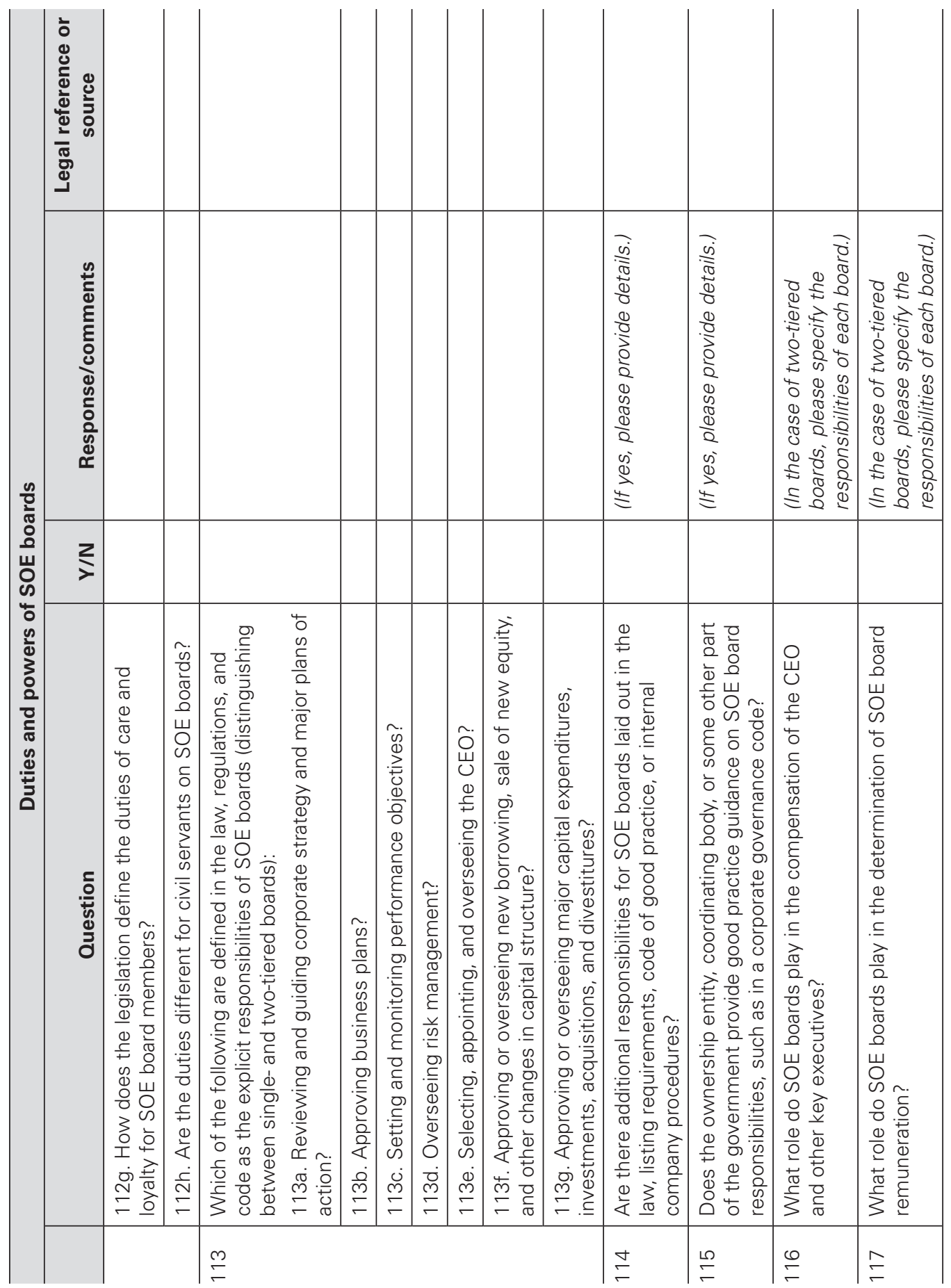




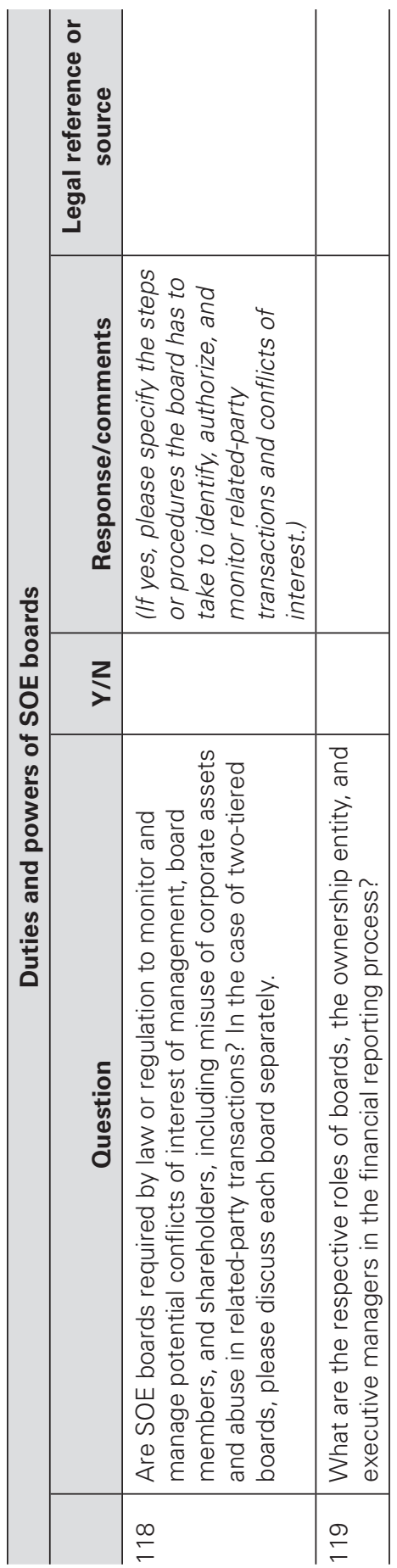




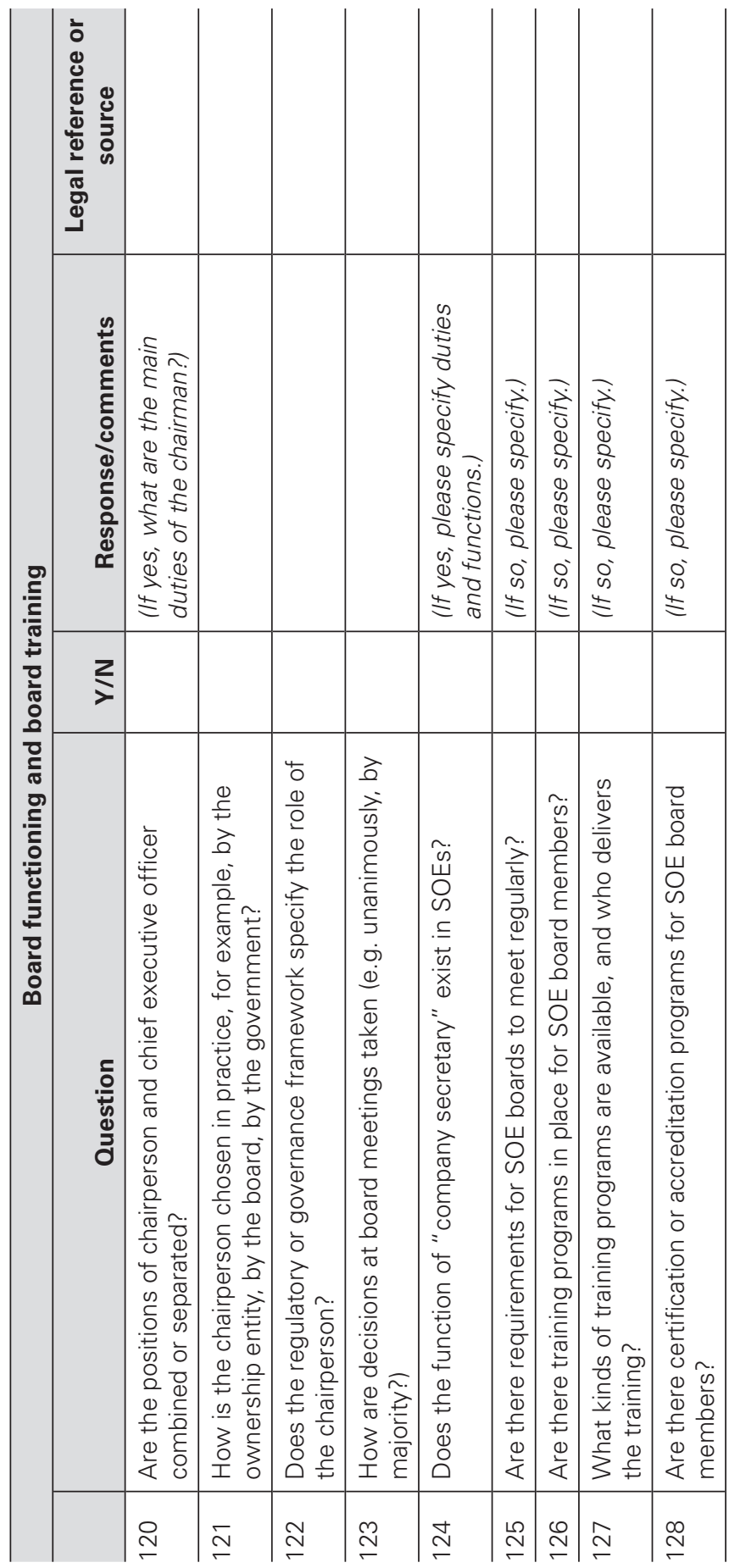




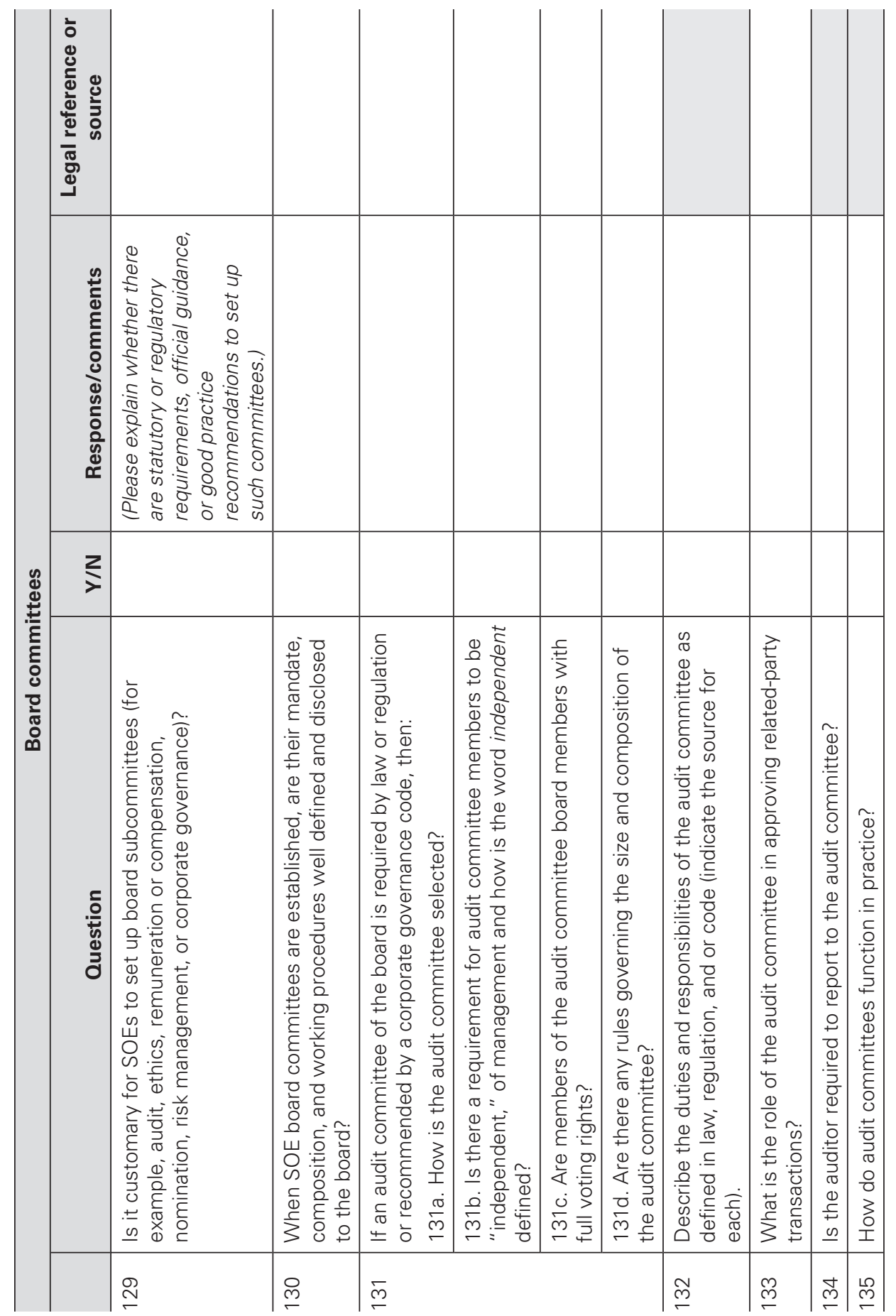




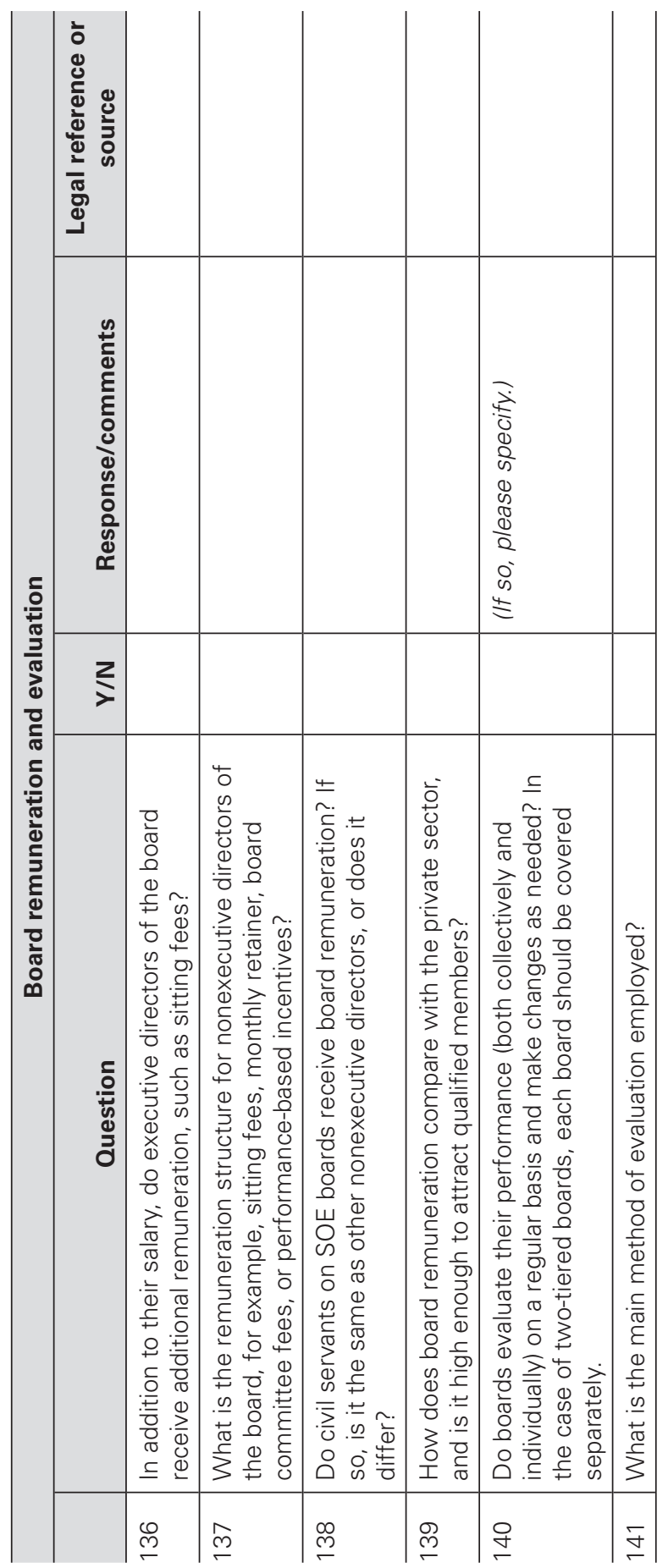




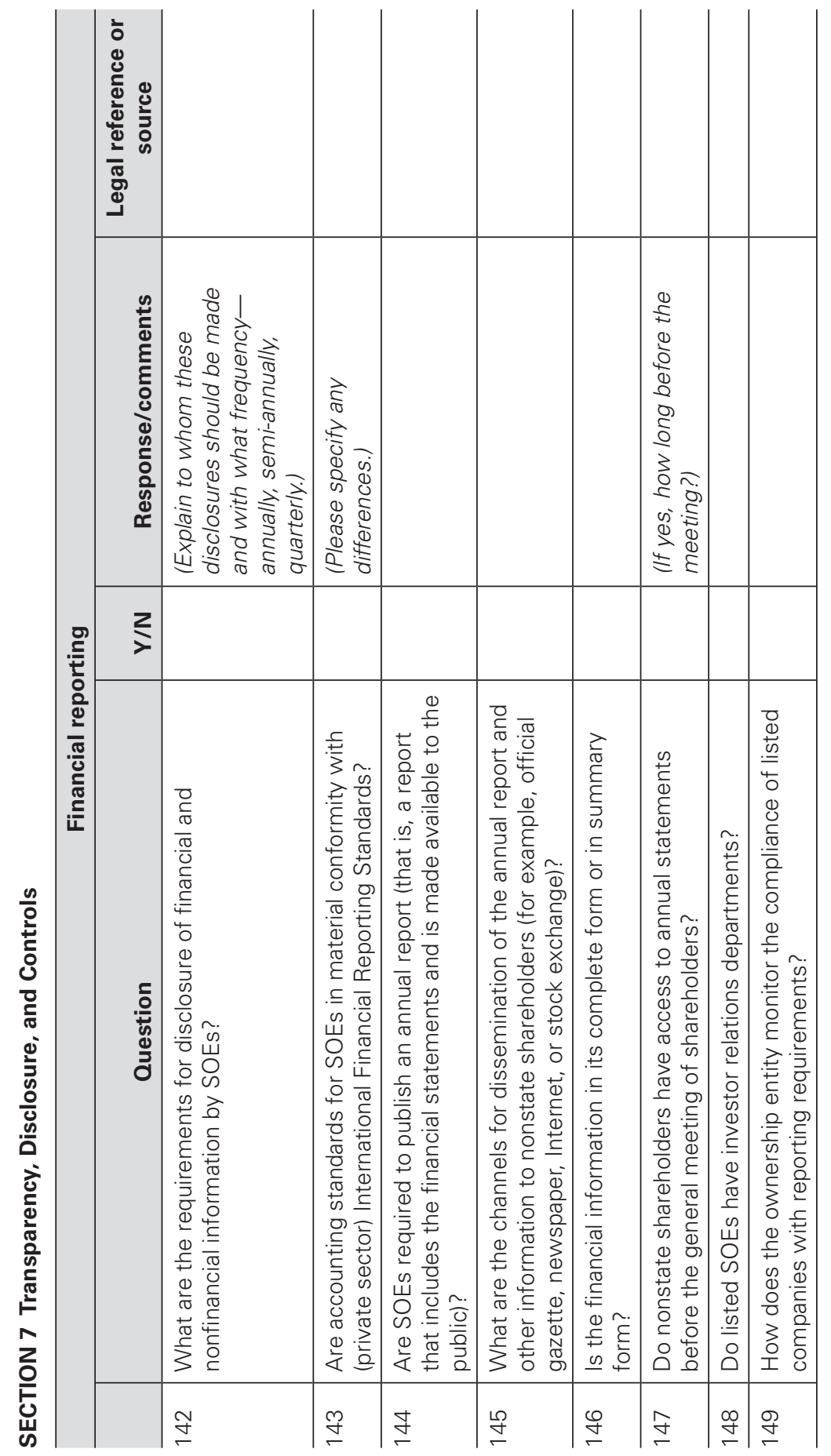




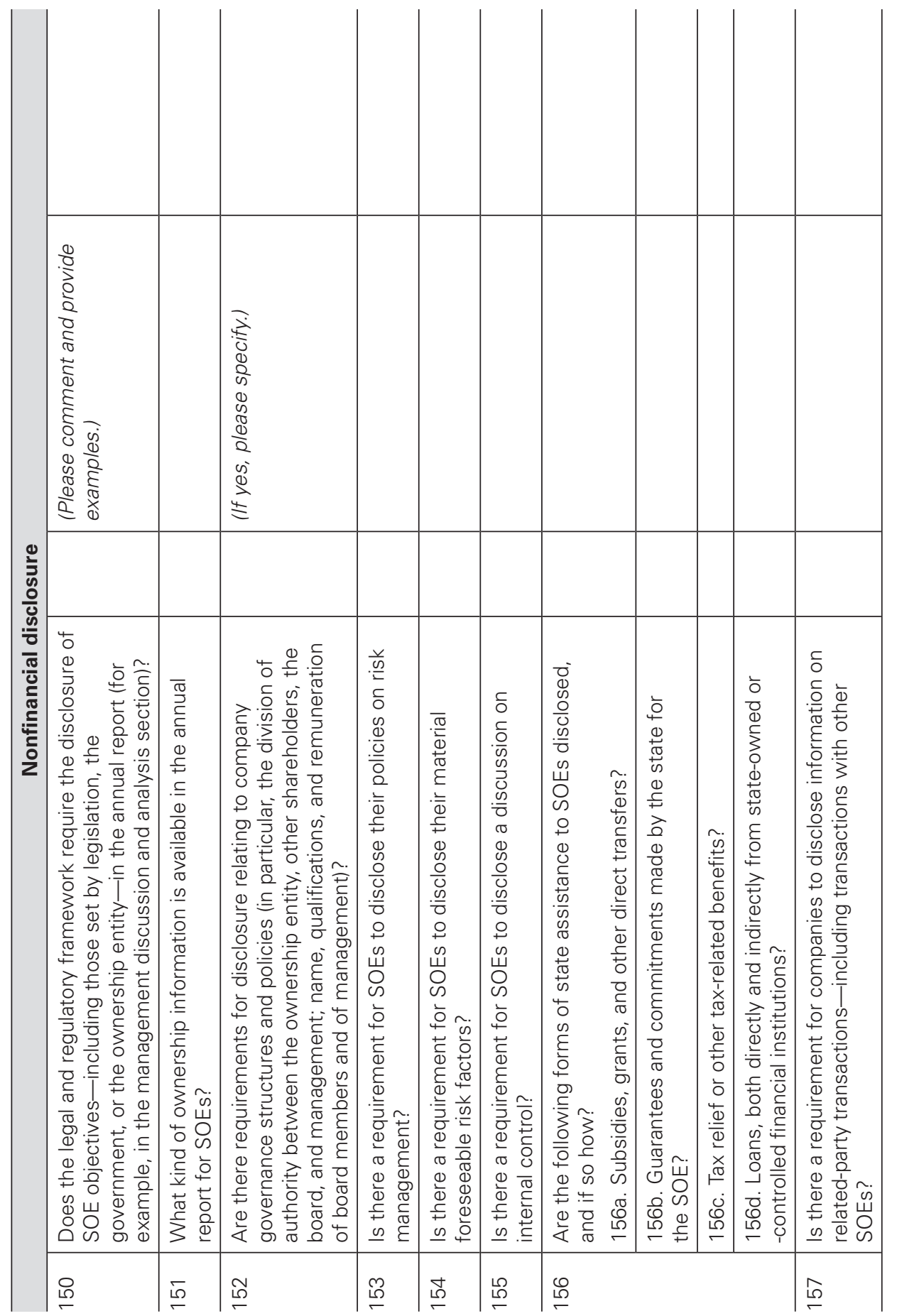




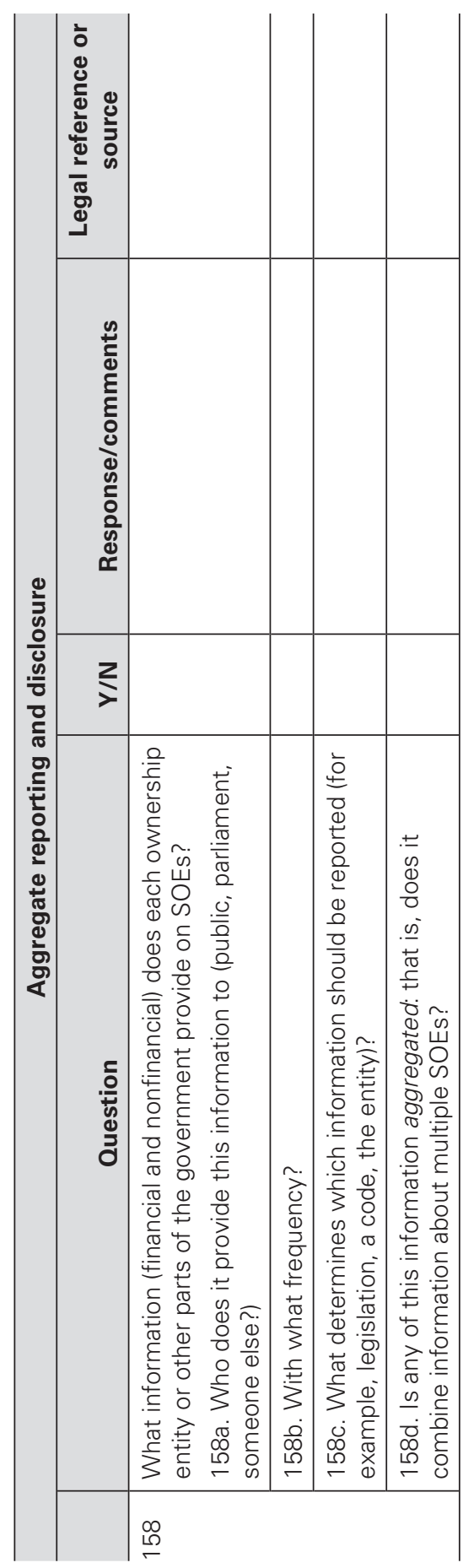




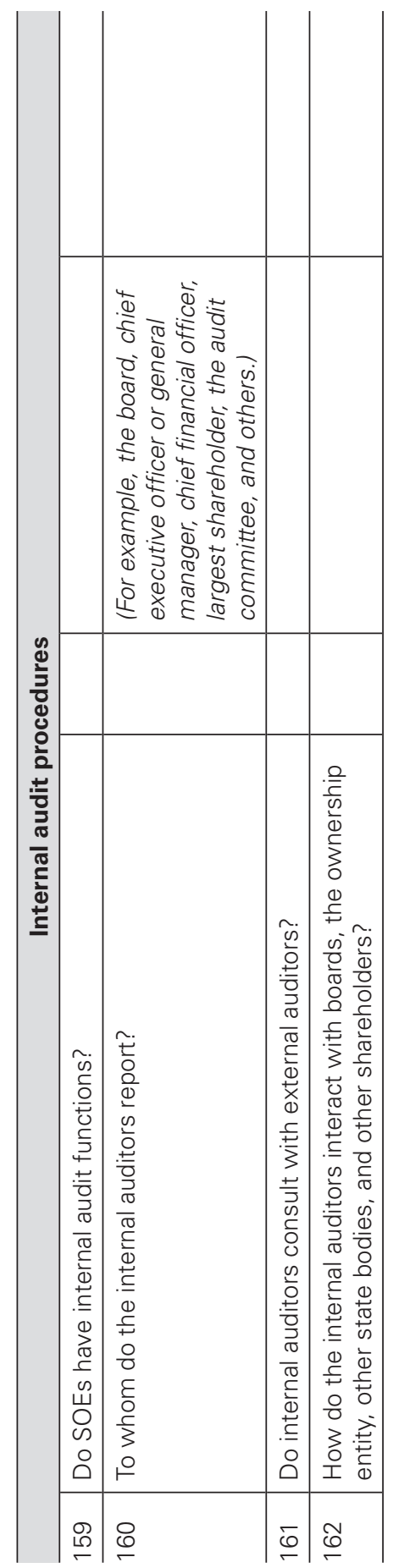




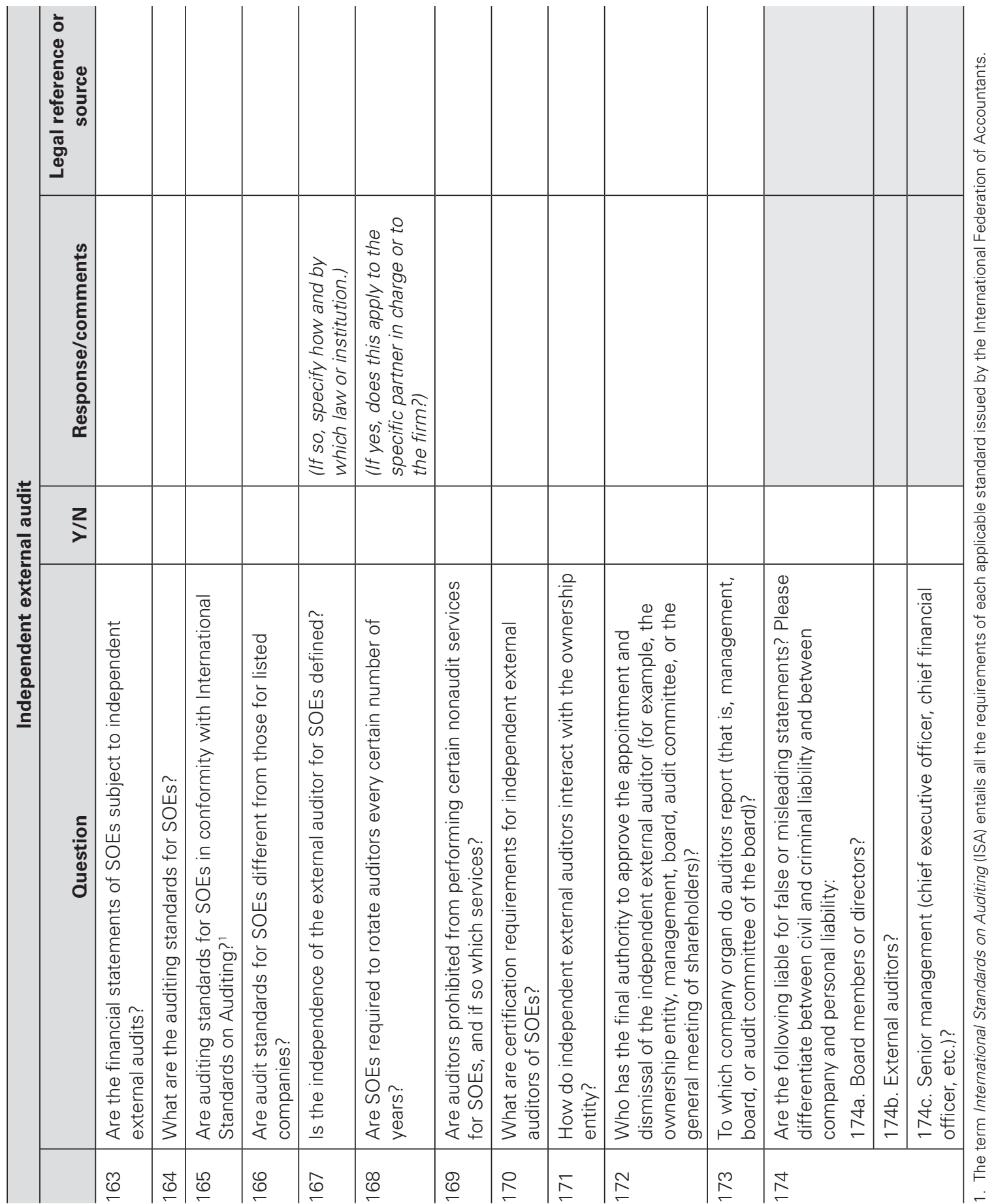




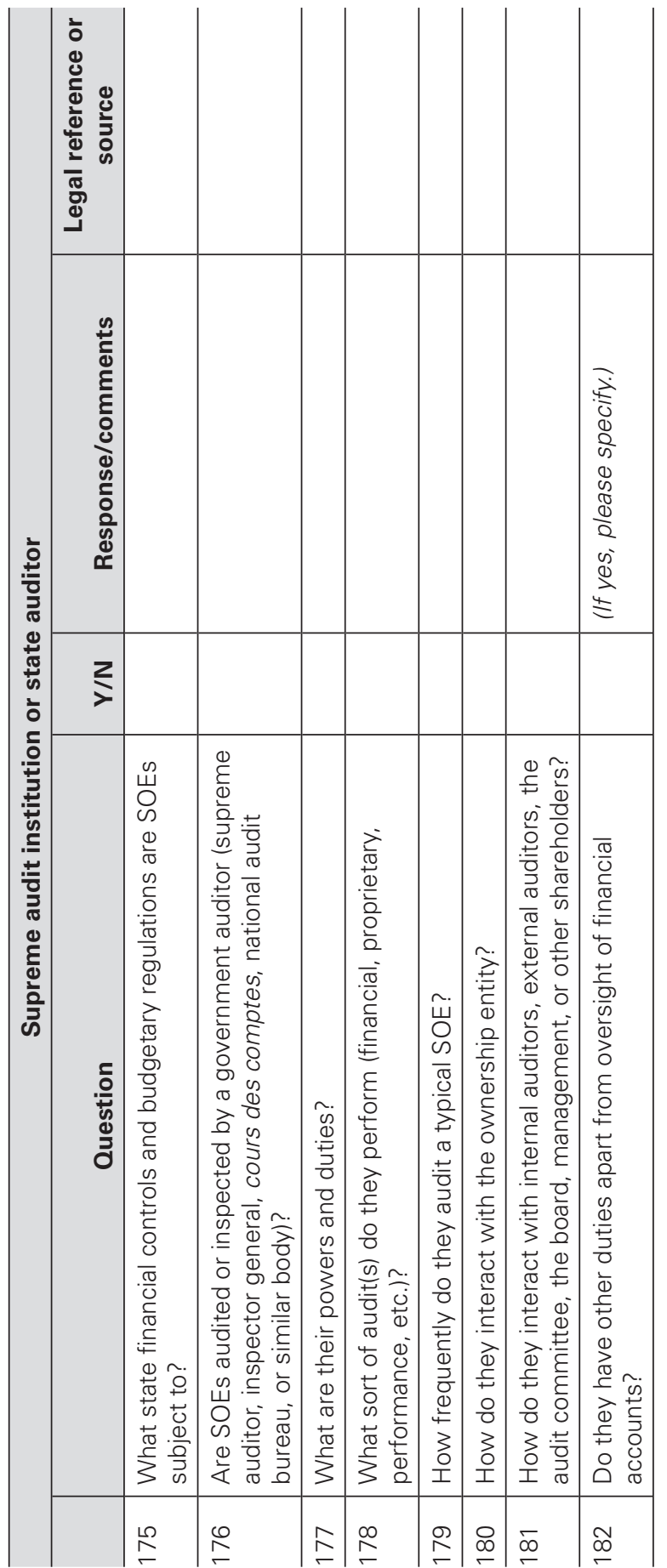




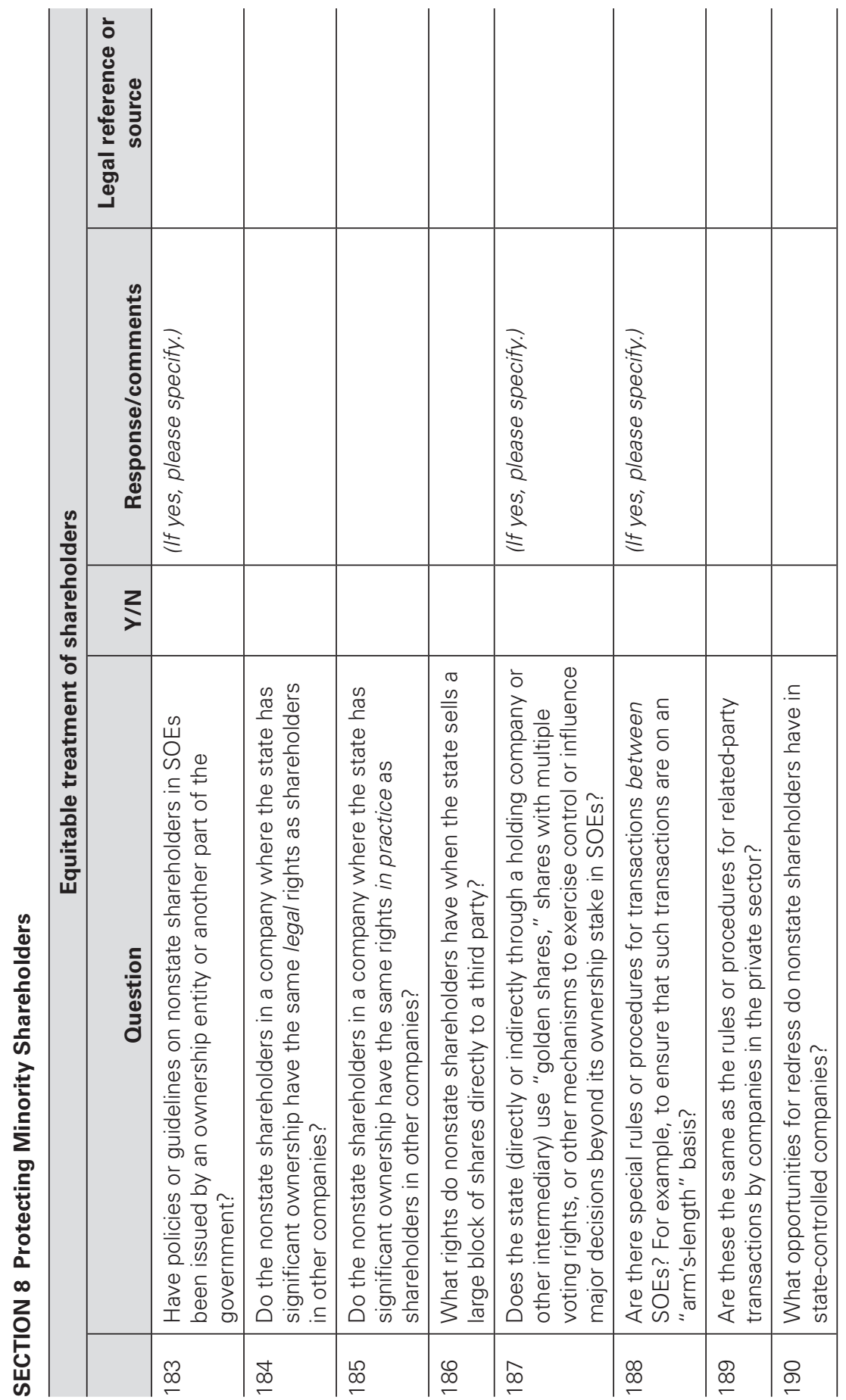




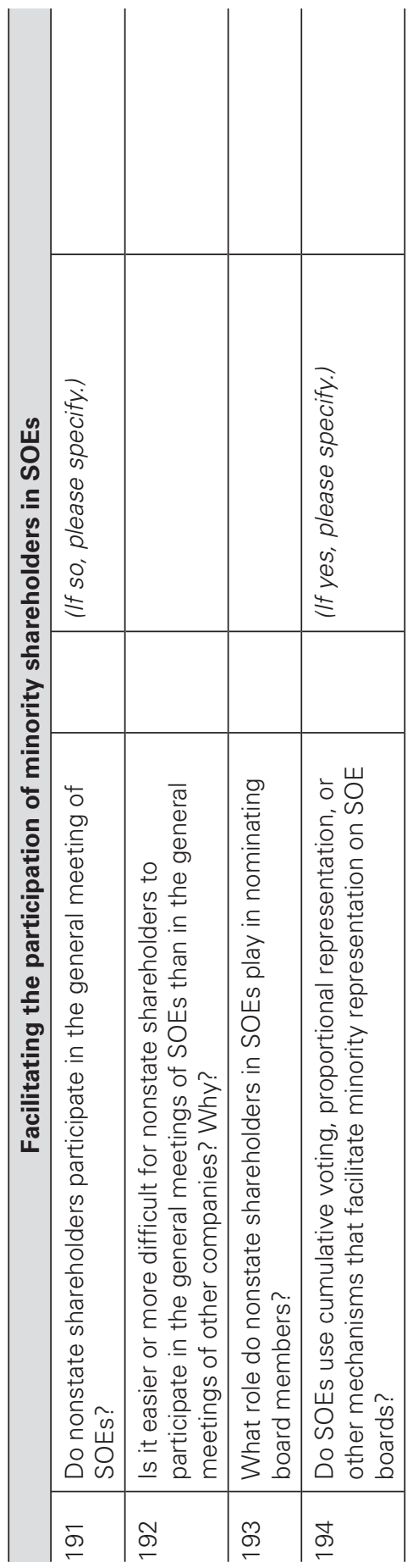




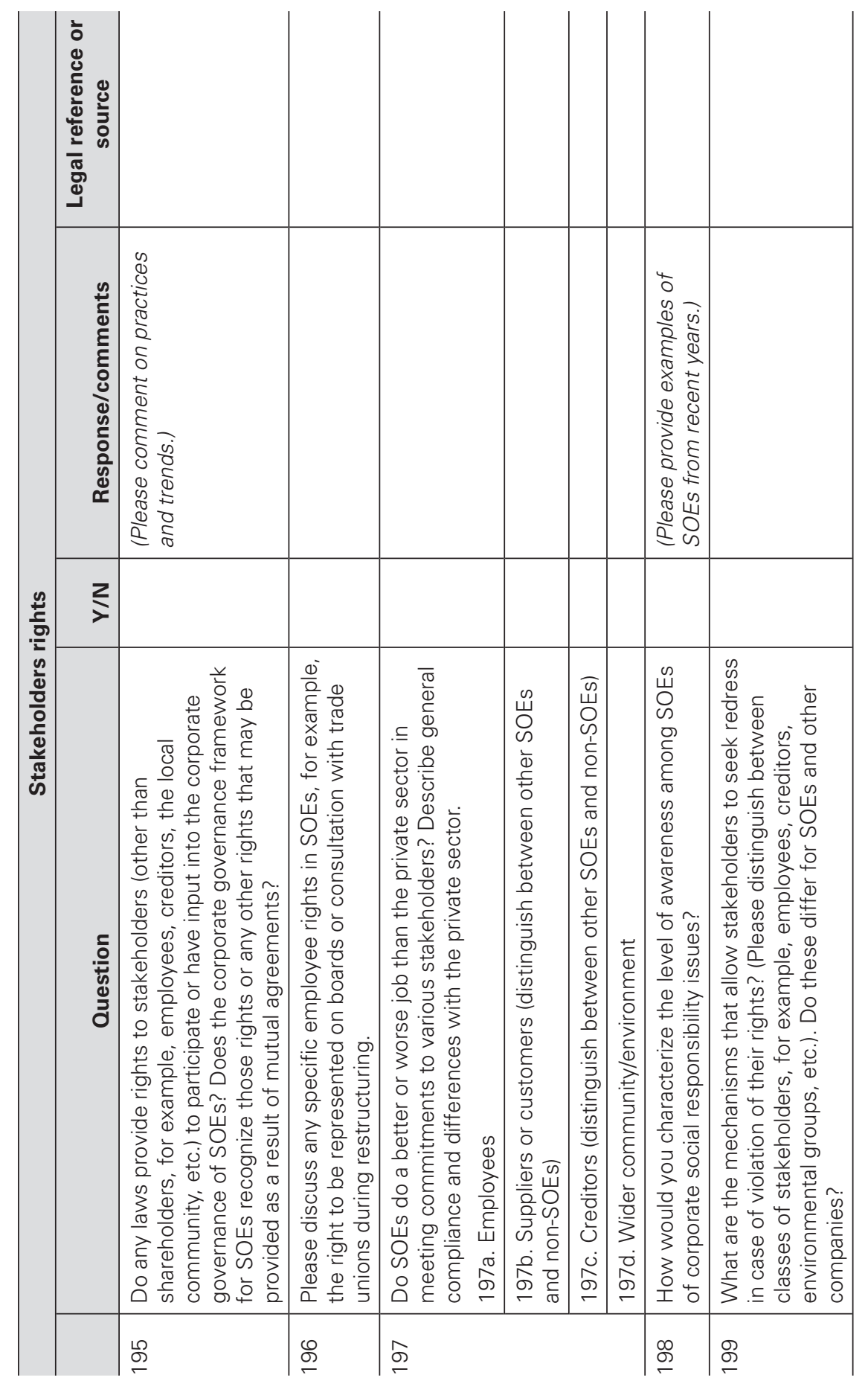




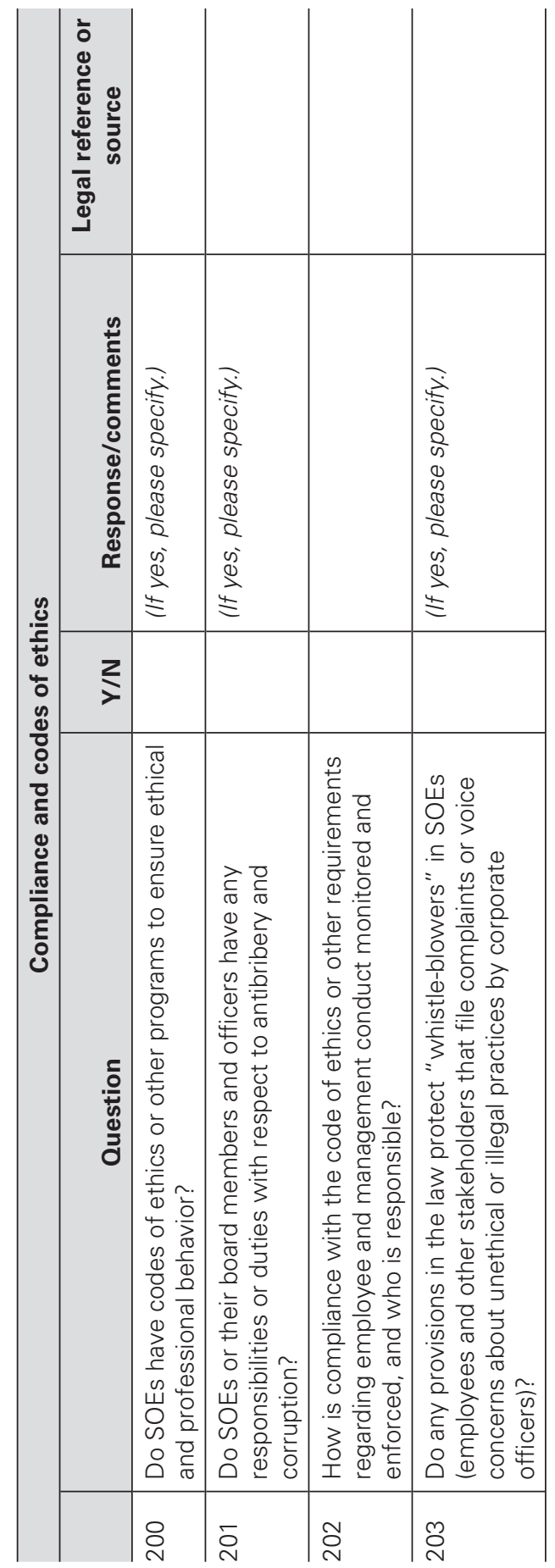




\section{Country-Level Tools: Sample Survey Instrument}

The sample survey instrument for state-owned enterprises (SOE) is intended for use as a diagnostic tool for compiling information on SOE corporate governance practices. The survey is composed of six sections:
A. Board of Directors and General Assembly
B. Company Objectives and Management
C. Internal Control
D. Transparency and Disclosure
E. Shareholder Protection
F. Corporate Governance Commitment

The survey is designed to be completed by a senior board member. If a senior board member is not available, then a senior manager or the secretary of the company should complete it.

Annual reports of the company for the past three years should be attached at the end of the survey. 


\section{Company Identification Data}

Name of the company.

Address.

Establishment date.

Company ownership structure:

State/government.

Other public sector institutions/banks.

Private sector.

Number of subsidiaries.

Number of branches.

Website.

Email address. 


\section{Survey}

Name of respondent. ...........................

Position of respondent in the company.

Number of years with the company.................

\section{A. BOARD OF DIRECTORS AND GENERAL ASSEMBLY}

1. Please provide the following description of the board:

Total number of board members ${ }^{1}$

Number of nonexecutive board members ${ }^{2}$

Number of executive members ${ }^{3}$

Number of independent nonexecutive board members ${ }^{4}$

Average age of board members

Average length of service of board members

Number of board members serving for 5 years or more

Chairman's length of service

2. Please indicate the number of board members from each of the following groups: ${ }^{5}$

Chairman

Experts or members with experience

Representatives of trade unions or employees

Representatives of private sector shareholders

3. Please indicate the number of board members with the following educational background: ${ }^{6}$

Bachelor's or higher degree in economics/business/accounting/law

Bachelor's or higher degree in engineering/other technical field

No university degree at all

4. Please indicate the number of board member experts (or members with experience) with the following professional background: ${ }^{7}$

Private sector/business entrepreneur

Public sector/civil servant background

Academician

Accountant

Lawyer

Other/please specify 
5. Please indicate the background of the chairman of the board:

Private sector/business entrepreneur

Public sector/civil servant background

Academician

Accountant

Lawyer

Other/please specify

6. Is the chairman of the board also serving as managing director ${ }^{8}$ of the company?

Yes

No

7. How many board members serve on how many other boards?

No other boards

Number of boards/number of members

$1-3$ boards

4-6 boards

7-10 boards

More than 10 boards

8. How many times did the board meet in the past fiscal year?

Formally

Informally

Total number of times

9. What was the average number of members attending the board meetings?

10. How many board members designated representatives to attend board meetings on their behalf and with what frequency? ${ }^{10}$

Never

Rarely (more than 1-5 times)

Sometimes (more than 6-10 times)

Always (more than 10 times)

11. How far in advance are board members notified of board meetings?

Less than 10 days

10-19 days

20-29 days

30 days or more

Frequency/number of board members 
12. Is the following information distributed to board members in advance of board meetings?

Yes/no

Financial statements

Audit reports

Related party and conflict-of interest-transactions

Managerial compensation/evaluation

Company strategy

Succession planning

13. How far in advance of board meetings are information materials distributed to board members?

Less than 10 days

10-19 days

20-29 days

30 days or more

14. In general, how satisfied is the board with the frequency, timeliness, and quality of materials provided to the board?

Frequency of information Highly satisfied Satisfied Somewhat satisfied Not satisfied

Timeliness of information

Quality of information

15. Does the board have any subcommittees (or similar structures) exclusively comprised of board members? Please check Yes/no below and describe their composition.

\begin{tabular}{|c|c|c|c|c|c|}
\hline & Yes/no & $\begin{array}{l}\text { Total number } \\
\text { of members }\end{array}$ & $\begin{array}{l}\text { Number of } \\
\text { independent } \\
\text { members }\end{array}$ & $\begin{array}{l}\text { Committee } \\
\text { chairman }^{11}\end{array}$ & $\begin{array}{c}\text { Frequency of } \\
\text { meetings per } \\
\text { year }\end{array}$ \\
\hline \multicolumn{6}{|l|}{ Audit committee } \\
\hline Nomination committee & & & & & \\
\hline Remuneration committee & & & & & \\
\hline $\begin{array}{l}\text { Corporate governance } \\
\text { committee }\end{array}$ & & & & & \\
\hline Ad hoc committee & & & & & \\
\hline No committee & & & & & \\
\hline
\end{tabular}

16. Has the board hired any external consultants for advice over the past 2 years?

Yes

No

Not legally permitted to do so 
17. If yes, does the board have a separate budget for hiring such consultants?

Yes

No

18. How are board members remunerated for their services? (multiple entries possible)

\begin{tabular}{|c|c|c|c|c|c|}
\hline & $\begin{array}{c}\text { Annual/ } \\
\text { monthly flat } \\
\text { rate }\end{array}$ & $\begin{array}{l}\text { Meeting } \\
\text { fees }\end{array}$ & $\begin{array}{c}\text { Travel and } \\
\text { other } \\
\text { allowances }\end{array}$ & $\begin{array}{l}\text { Other/ } \\
\text { please } \\
\text { specify }\end{array}$ & $\begin{array}{c}\text { No } \\
\text { remuneration }^{12}\end{array}$ \\
\hline \multicolumn{6}{|l|}{ Chairman } \\
\hline \multicolumn{6}{|l|}{$\begin{array}{l}\text { Nonexecutive directors } \\
\text { Independent nonexecutives }\end{array}$} \\
\hline Independent nonexecutives & & & & & \\
\hline \\
\hline All of the above & & & & & \\
\hline
\end{tabular}

19. What is the average annual amount received by each board member in each of the following groups?

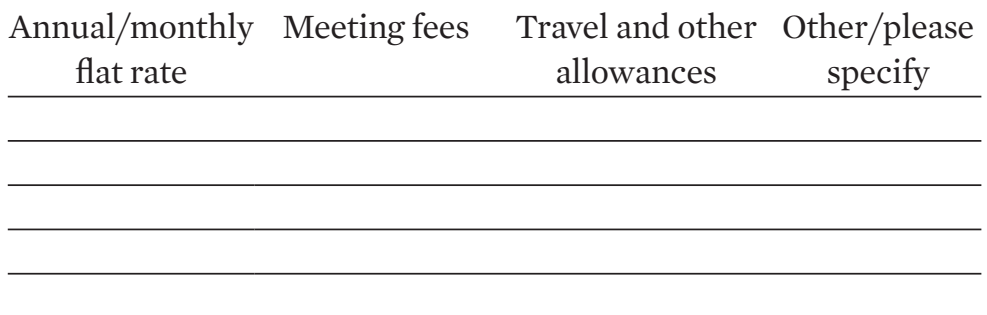

Chairman

Nonexecutive directors

Independent nonexecutives

Executive directors

All of the above

20. How many board members have taken a board director's training program?

21. Who formally evaluates the performance of the board?

Ownership unit

General assembly

Company board itself

No formal evaluation in place

22. Whose performance is evaluated?

Board as a whole

Individual board members

Both of the above 
23. How is the performance of individual board members assessed? (multiple entries possible)

Through individual feedback from chairman of the board

Through individual feedback from shareholders

Through a special committee of the board

Through a formal performance appraisal system within the board

Through feedback from senior management

Number of meetings attended

Through achievement of company goals

Through self-appraisal

No assessment process in place

Planning to introduce performance assessment system

24. Has the general assembly in the past two years taken a decision to remove any of the following board members during their term?

Chairman of the board

Entire board

Some members of the board

No removal decision has been taken

25. Is there a specific company policy or document in place specifying the board's role in managing conflicts of interest ${ }^{13}$ or related party transactions? ${ }^{14}$

Yes

No

26. Have there been any related-party transactions in the past two years?

Yes

No

27. Who approves related party transactions?

General assembly of the company

Board of the company

Other/please specify

\section{B. COMPANY OBJECTIVES AND MANAGEMENT}

28. Who sets the company's commercial and noncommercial objectives ${ }^{15}$

Ownership unit

Line ministry

General assembly

Company board 
Managing director

Senior management

29. Does the company prepare a strategic business plan?

Yes

No

30. Who is involved in the strategic planning process? (multiple entries possible)

Ownership unit

Line ministry

General assembly

Company board

Managing director

Senior management

31. Who in the company prepares the annual budget?

Managing director

Senior management

Functional department

Other/please specify

32. Please specify the month in which the annual budget is typically prepared.

33. Please list the main items covered in the annual budget.

34. Which body approves the following items?

\begin{tabular}{|c|c|c|c|c|c|}
\hline & $\begin{array}{c}\text { Ownership } \\
\text { Unit }\end{array}$ & $\begin{array}{c}\text { General } \\
\text { assembly }\end{array}$ & $\begin{array}{c}\text { Company } \\
\text { board }\end{array}$ & $\begin{array}{c}\text { Managing } \\
\text { director }\end{array}$ & $\begin{array}{c}\text { Senior } \\
\text { management }\end{array}$ \\
\hline \multicolumn{6}{|l|}{ Company objectives } \\
\hline \multicolumn{6}{|l|}{ Strategic plan } \\
\hline \multicolumn{6}{|l|}{ Annual budget } \\
\hline \multicolumn{6}{|l|}{ Financial targets } \\
\hline \multicolumn{6}{|l|}{ Product pricing } \\
\hline \multicolumn{6}{|l|}{ Hiring and firing of staff } \\
\hline \multicolumn{6}{|l|}{ Salary increase } \\
\hline Performance-based bonus & & & & & \\
\hline
\end{tabular}

35. Does the company have the flexibility to independently set wages for managers and employees? Yes

No 
36. Please specify the following:

Number of senior management positions in the company ${ }^{16}$ Average age of senior management members Length of service of managing director

37. Does the company have a formal performance monitoring mechanism in place?

Yes

No

Planning to introduce

38. On what basis is the performance of senior management assessed? (multiple entries possible)

Through individual feedback from the managing director

Through board review

On the basis of the achievement of company goals and targets

Through individual feedback from shareholders

Through a formal performance appraisal system

Through feedback from peers

Through self-appraisal

No assessment carried out

Planning to introduce performance assessment

\section{INTERNAL CONTROL}

39. Does the company have an internal control function?

Yes

No

40. If yes, what are its main functions? (multiple entries possible)

Insure completeness and accuracy of financial information

Mitigate conflict of interest

Check compliance with legal norms and regulations

Check compliance with internal documents/by-laws/standards

Verify related party transactions

Other/please specify

41. Whom does the head of internal control report to and how often?

Chairman of the board

Monthly Quarterly Semi-annually Annually

Board as a whole 
Managing director

Senior management

Other/please specify

42. Does the company have a separate internal audit unit or department? ${ }^{17}$

Yes

No

43. If yes, what are its main functions? (multiple entries possible)

Independent appraiser of internal controls and compliance

Verification of functional information

Assistant to management

Policeman

Support for state auditor

Support for external auditor

Consultant to improve operational efficiency

Other/please specify

44. Whom does the head of the internal audit department report to and how often?

Chairman of the board

Monthly Quarterly

Semi-annually

Annually

Board as a whole

Audit Committee

Managing director

Senior management

Other/please specify

45. Who appoints and dismisses the head of the internal audit department?

General assembly

Board

Audit committee

Managing director

Senior management

Other/please specify

Appoints

Dismisses

46. Does the same person head the internal control and the internal audit departments?

Yes

No 
47. Is the company having trouble implementing the change from the unified accounting system to international accounting standards?

Yes

No

48. Are whistle-blowing procedures in place to protect employees or other stakeholders? ${ }^{18}$

Yes

No

D. TRANSPARENCY AND DISCLOSURE

49. Does the company retain an independent external audit firm? ${ }^{19}$

Yes

No

50. If no, what are the reasons for not retaining an independent external audit firm? (multiple entries possible)

No legal requirement

State audit sufficient

No additional value

Lack of resources

Other/please specify

51. Does the company have written disclosure policies, in addition to legal requirements?

Yes

No

52. Does the company disclose any of the following information to the ownership unit and to the general public? (multiple entries possible)

Financial information

Financial statements

Audit reports

Board of director reports

Any contingent fundamental conditions/risks affecting

the company's financial position

Nonfinancial information

Company objectives and strategy

Compliance with corporate governance code 
Organizational chart

Biographical information about board members

Remuneration of board members

Biographical information about senior management

Remuneration of senior management

Significant related-party transactions

Other information

Articles or founding act

Annual general meeting resolutions

53. If no, what prevents the company from disclosing additional information? (multiple entries possible)

No legal requirement

No economic value

No demand

Lack of resources

54. What methods does the company generally use to disseminate information to the general public? (multiple entries possible)

Company website

Newspaper/local journals

Other/please specify

\section{E. SHAREHOLDER PROTECTION}

55. Does the company have a code of ethics?

Yes

No

56. Does the company have a shareholder agreement or any specific guidelines or regulations that govern the relations between majority and minority shareholders?

Yes

No

57. How are shareholders informed of the annual general meeting? (multiple entries possible)

Notice in the press

Notice sent by mail

Announcement on company website 
Through company branches

Other/please specify

58. How far in advance are shareholders informed of the date of the meeting?

Less than 10 days

10-19 days

20-29 days

30 days or more

59. What information do shareholders receive in advance of the meeting? (multiple entries possible)

Agenda of the meeting

Financial statements

Audit report

Nonfinancial information

Annual report

Other documents/please specify

None of the above

60. How are the results of the meeting distributed among shareholders? (multiple entries possible):

By mail

By email

Published in the press

Published on the company website

Available on request

Not distributed at all

61. How are the results of the meeting disseminated to the broader public? (multiple entries possible)

Published in the press

Announcement on the company website

Available on request

Other/please specify

Not disseminated to the public

62. Have shareholders ever taken legal action against the company?

Yes

No 


\section{F. CORPORATE GOVERNANCE COMMITMENT}

63. Are you familiar with the corporate governance policy for state-owned enterprises? ${ }^{20}$

Yes

No

64. In the past two years, has the company undertaken any specific measures aimed at improving corporate governance? (multiple entries possible)

Establishment of board committees

Formalization of board functions and responsibilities

Establishment of internal audit

Improvement of disclosure and transparency

Improvement of internal documentation

Other/please specify

No specific measures undertaken

65. What were the main reasons for undertaking the above measures? (multiple entries possible)

Legal/regulatory requirements

Change of ownership/shareholder base

Need to attract external investments

Need to improve efficiency of operations

Need to improve stakeholder coordination

Improvements required by shareholders

Improvements required by the board

Other/please specify

66. Does the company plan to undertake any of the following measures in the next two years? (multiple entries possible)

Establish board committees

Establish an internal audit system

Improve internal documentation

Improve disclosure

Obtain consultancy support on corporate governance issues

Other/please specify

No particular measures foreseen

67. Does the company have a designated corporate governance officer or company secretary responsible only for corporate governance practices in the company?

Yes

No

Planning to introduce 
68. Which main goals should improvements to corporate governance in your company aim to achieve?

Attract external investments

Improve operational efficiency

Improve stakeholder coordination

Improve capitalization

Improve the internal control system

Enhance public image

Conform with laws/regulations

Other/please specify

69. In your opinion, how important is corporate governance for your company?

Very important

Important

Somewhat important

Not important

70. In your opinion, what is the current status of corporate governance in your company?

Well developed

Sufficiently developed

Underdeveloped

Poor

Critically poor

Other/please specify

71. In your opinion, what is the current status of corporate governance in state-owned enterprises?

Well developed

Sufficiently developed

Underdeveloped

Poor

Critically poor

Other/please specify

72. In your opinion, what hinders the improvement of corporate governance in state-owned enterprises in general?

Lack of knowledge and experience

Insufficient economic motivation to do so

Deficiencies in the legal framework for state owned enterprises

Lack of a broad shareholder base

Lack of financial resources 
Lack of efficient internal control system

Lack of support from shareholders

Lack of support from the board

Lack of managerial accountability

Internal resistance from key staff

Lack of political support

\section{Notes}

1. The total number of board members should be equal to the sum of nonexecutive members and executive members.

2. A nonexecutive board member is an individual who does not hold a full-time management position in the same company.

3. An executive board member is an individual who also holds a full-time management position in the same company.

4. A nonexecutive board member is considered independent if he or she is not a full-time employee, is not a representative of a major shareholder, and is not otherwise connected to the company. See chapter 6 of the toolkit for a detailed definition of board independence.

5. The total number of members in the table should equal the total number of board members in question 1 , line 1.

6. The total number of members in the table below should equal the total number of board members in question 1 , line 1 .

7. The total number of members in the table should equal the same as line 2, question 2.

8. The managing director can also be called chief executive officer or general director. It refers to the principal full-time executive (full-time employee).

9. The total number of members in the table below should equal the total number of board members in line 1, question 1.

10. The total number of members in question 10 should equal the total number of board members in line 1, question 1.

11. Please indicate which of the following chairs the committee: (1) chairman of the board; (2) independent member of the board; (3) other/please specify.

12. For executive members, "no remuneration" means that they receive no remuneration beyond their normal salary and benefits as employees of the company.

13. Conflict of interest is a clash between the personal interests of a company officer or his or her related parties and his or her official (professional) duty to act in the best interests of the company.

14. Related-party transactions are transactions between: (1) company managers; (2) major stakeholders; (3) close relatives, spouse, children, parents of managers or stakeholders; and (4) company's affiliated persons, managers, and holders of major stakes in affiliated persons and their close relatives. 
15. This question would have to be customized, depending on the ownership structure in a given country.

16. Please define senior management as defined by the company.

17. Internal audit is an independent department that is not involved in operations but makes regular inspections and evaluates internal control issues, financial and other reporting, observance of accounting principles and internal procedures, and conformity to regulatory requirements.

18. A whistleblower is an informant, most often an employee, who reports employer misconduct.

19. In addition to any audits performed by state control bodies or the supreme audit institution.

20. This policy would have to be customized in line with local regulation (and should refer to the local corporate governance code, policy, and the like). 



\section{Company-Level Tools: Instruction Sheet}

This instruction sheet describes three company-level tools for carrying out a review of the corporate governance practices of an individual state-owned enterprise (SOE) and indicates who should be interviewed in the course of conducting the review.

- SOE progression matrix. The progression matrix relates five areas of SOE governance-financial and fiscal discipline; board of directors; transparency, disclosure, and controls; treatment of minority shareholders; and commitment to corporate governance-to four levels of achievement, from acceptable corporate governance practices (level 1) to leadership practices (level 4). The use of a matrix framework emphasizes the importance of ongoing improvements in the governance practices of SOEs rather than the application of rigid and static minimum standards. In particular, the progression matrix allows SOEs or their owners to assess the governance of the company against this framework.

Note: Adapted from the Corporate Governance Development Framework of the International Finance Corporation. 
- Information request list and interview guide. The information request list and interview guide form the basis for the SOE corporate governance review. They consist of the main questions that should be covered in the review, organized along the five areas of governance identified in the progression matrix. The company should name a single officer charged with responding to the questions by providing brief written answers of one or two paragraphs to each of the questions.

- Sample corporate governance improvement program. In many cases, the corporate governance review of an SOE will result in the drafting and negotiation of a corporate governance improvement program to be implemented by the SOE. The improvement program should be tailored to the circumstances and priorities of the company. The sample improvement program gives an idea of what has been included in most programs and can therefore be used as a reference point in the drafting process.

A thorough corporate governance review requires direct discussions with the people who play significant roles in the company. A list of those who would normally be interviewed is provided below. Because companies differ in how they apportion responsibilities and in the titles they use for different positions in the company, it is important to meet with the company staff responsible for the principal corporate governance functions, regardless of their job titles. These include:

- Representatives of controlling shareholders (possibly a combination of state representatives, depending on the state's share ownership and control policies)

- Representatives of other holders of significant blocks of shares

- Chairperson and members of the board of directors, including any "independent" board members and the chairs of the audit and other special committees of the board

- Chief executive officer

- Chief financial officer (or senior accounting officer)

- General counsel (or senior lawyer)

- Corporate secretary

- Chief of internal audit and internal controls

- Chief of investor relations

- Independent external auditors

- State auditors or supreme auditors (depending on the specific circumstances) 
APPENDIX E

Company-Level Tools: State-Owned Enterprise

Progression Matrix 


\begin{tabular}{|c|c|c|c|c|}
\hline Attributes & $\begin{array}{l}\text { Level 1: Acceptable } \\
\text { corporate } \\
\text { governance } \\
\text { practices }\end{array}$ & $\begin{array}{l}\text { Level 2: Extra steps } \\
\text { to ensure good } \\
\text { corporate } \\
\text { governance }\end{array}$ & $\begin{array}{l}\text { Level 3: Major } \\
\text { contribution to } \\
\text { improving corporate } \\
\text { governance nationally }\end{array}$ & Level 4: Leadership \\
\hline $\begin{array}{l}\text { A. Financial } \\
\text { discipline }\end{array}$ & $\begin{array}{l}\text { - The company's } \\
\text { commercial and } \\
\text { policy objectives } \\
\text { are explicit and } \\
\text { disclosed to the } \\
\text { public. } \\
\text { - Funding costs and } \\
\text { sources of funding } \\
\text { are transparent. } \\
\text { - Bank financing is } \\
\text { procured under } \\
\text { competitive } \\
\text { processes. }\end{array}$ & $\begin{array}{l}\text { - The costs of } \\
\text { meeting the } \\
\text { company's policy } \\
\text { objectives are } \\
\text { valued using } \\
\text { internationally } \\
\text { accepted } \\
\text { accounting, } \\
\text { financial, and } \\
\text { economic } \\
\text { techniques and } \\
\text { are disclosed } \\
\text { separately in the } \\
\text { financial } \\
\text { statements. } \\
\text { - The company's } \\
\text { financial } \\
\text { statements } \\
\text { separately report } \\
\text { the impact any } \\
\text { state benefits } \\
\text { such as } \\
\text { concessionary } \\
\text { funding (including } \\
\text { guarantees) for its } \\
\text { commercial } \\
\text { activities. } \\
\text { - A commercial } \\
\text { capital structure } \\
\text { and dividend } \\
\text { policy appropriate } \\
\text { for the sector are } \\
\text { in place. } \\
\text { - A bond rating is in } \\
\text { place, and the } \\
\text { company has } \\
\text { issued corporate } \\
\text { bonds. }\end{array}$ & $\begin{array}{l}\text { - The costs of } \\
\text { meeting the } \\
\text { company's policy } \\
\text { objectives are } \\
\text { funded separately by } \\
\text { the state. } \\
\text { - The company has a } \\
\text { performance-linked } \\
\text { reward system } \\
\text { aligned with its } \\
\text { objectives. }\end{array}$ & $\begin{array}{l}\text { - The company's } \\
\text { objectives are } \\
\text { solely commercial. } \\
\text { - The company's } \\
\text { equity is listed. } \\
\text { - The company has } \\
\text { an optimal mix of } \\
\text { bond financing } \\
\text { and bank } \\
\text { financing. }\end{array}$ \\
\hline $\begin{array}{l}\text { B. Structure } \\
\text { and } \\
\text { Functioning of } \\
\text { the board of } \\
\text { directors }\end{array}$ & $\begin{array}{l}\text { - The board includes } \\
\text { nonexecutive } \\
\text { members with } \\
\text { commercial and } \\
\text { financial }\end{array}$ & $\begin{array}{l}\text { - The board } \\
\text { includes } \\
\text { nonexecutive } \\
\text { members from } \\
\text { the private sector. }\end{array}$ & $\begin{array}{l}\text { - The board has a } \\
\text { significant number } \\
\text { of formally } \\
\text { independent } \\
\text { members. }\end{array}$ & $\begin{array}{l}\text { - The board is } \\
\text { dominated by } \\
\text { members from } \\
\text { the private sector. }\end{array}$ \\
\hline
\end{tabular}




\begin{tabular}{|c|c|c|c|c|}
\hline Attributes & $\begin{array}{l}\text { Level 1: Acceptable } \\
\text { corporate } \\
\text { governance } \\
\text { practices }\end{array}$ & $\begin{array}{l}\text { Level 2: Extra steps } \\
\text { to ensure good } \\
\text { corporate } \\
\text { governance }\end{array}$ & $\begin{array}{l}\text { Level 3: Major } \\
\text { contribution to } \\
\text { improving corporate } \\
\text { governance nationally }\end{array}$ & Level 4: Leadership \\
\hline & $\begin{array}{l}\text { experience; no } \\
\text { ministers or } \\
\text { elected officials } \\
\text { serve on the } \\
\text { board. } \\
\text { - The board } \\
\text { oversees key } \\
\text { activities; the } \\
\text { state's role in } \\
\text { approving or } \\
\text { guiding key } \\
\text { activities is clear. } \\
\text { Board members } \\
\text { seek to avoid } \\
\text { conflicts and } \\
\text { declare them to } \\
\text { the board. } \\
\text { The board meets } \\
\text { regularly, and } \\
\text { board members } \\
\text { understand their } \\
\text { tasks, duties, and } \\
\text { responsibilities. } \\
\text { Board members } \\
\text { are provided with } \\
\text { adequate and } \\
\text { timely information. } \\
\text { The board is not so } \\
\text { large as to hinder } \\
\text { effective } \\
\text { deliberation. }\end{array}$ & $\begin{array}{l}\text { - The board } \\
\text { oversees } \\
\text { management, } \\
\text { budgets, strategy, } \\
\text { major } \\
\text { expenditures, and } \\
\text { the like; the } \\
\text { state's role in } \\
\text { approving or } \\
\text { guiding these } \\
\text { areas leaves } \\
\text { sufficient } \\
\text { autonomy to the } \\
\text { board. } \\
\text { - The board } \\
\text { manages } \\
\text { potential conflicts } \\
\text { of interest; it has } \\
\text { a code of ethics } \\
\text { or conduct. } \\
\text { - The board uses } \\
\text { written policies } \\
\text { and procedures. } \\
\text { - An audit } \\
\text { committee is in } \\
\text { place, with at } \\
\text { least one } \\
\text { independent } \\
\text { member. } \\
\text { - Board members' } \\
\text { pay is linked to } \\
\text { responsibilities. } \\
\text { - Board members } \\
\text { have taken some } \\
\text { leadership and } \\
\text { development } \\
\text { training. }\end{array}$ & $\begin{array}{l}\text { - The board selects } \\
\text { the CEO and sets } \\
\text { CEO pay. } \\
\text { - The board ensures } \\
\text { the integrity of } \\
\text { financial reporting, } \\
\text { internal control and } \\
\text { internal audit, and } \\
\text { risk management } \\
\text { systems. } \\
\text { - The position of chair } \\
\text { is separate from the } \\
\text { position of CEO. } \\
\text { - The audit committee } \\
\text { oversees internal } \\
\text { audit and controls } \\
\text { and is composed } \\
\text { primarily of } \\
\text { independent } \\
\text { members. } \\
\text { - Committees with } \\
\text { independent } \\
\text { members oversee } \\
\text { such areas as } \\
\text { remuneration, } \\
\text { nomination, and } \\
\text { conflicts of interest. } \\
\text { - Evaluations of the } \\
\text { board and CEO are } \\
\text { conducted. }\end{array}$ & $\begin{array}{l}\text { - The board has a } \\
\text { majority of } \\
\text { independent } \\
\text { directors, } \\
\text { including a chair } \\
\text { who is } \\
\text { independent of } \\
\text { the government. } \\
\text { - The board has full } \\
\text { authority and } \\
\text { autonomy as } \\
\text { provided in } \\
\text { company law and } \\
\text { practice for listed } \\
\text { companies. } \\
\text { - The audit } \\
\text { committee has all } \\
\text { independent } \\
\text { members and } \\
\text { primary authority } \\
\text { over internal audit. } \\
\text { - All board } \\
\text { members receive } \\
\text { induction and } \\
\text { ongoing } \\
\text { leadership and } \\
\text { development } \\
\text { training. }\end{array}$ \\
\hline $\begin{array}{l}\text { C. Transparency, } \\
\text { disclosure, and } \\
\text { controls }\end{array}$ & $\begin{array}{l}\text { - The SOE has a } \\
\text { system of internal } \\
\text { controls in place. }\end{array}$ & $\begin{array}{l}\text { - Internal controls } \\
\text { and internal audit } \\
\text { units are in place, } \\
\text { staffed, and }\end{array}$ & $\begin{array}{l}\text { - The state audit } \\
\text { institution audits use } \\
\text { of public funds and } \\
\text { implementation of }\end{array}$ & $\begin{array}{l}\text { - The design } \\
\text { of internal } \\
\text { control systems } \\
\text { complies with }\end{array}$ \\
\hline
\end{tabular}




\begin{tabular}{|c|c|c|c|c|}
\hline Attributes & $\begin{array}{l}\text { Level 1: Acceptable } \\
\text { corporate } \\
\text { governance } \\
\text { practices }\end{array}$ & $\begin{array}{l}\text { Level 2: Extra steps } \\
\text { to ensure good } \\
\text { corporate } \\
\text { governance }\end{array}$ & $\begin{array}{l}\text { Level 3: Major } \\
\text { contribution to } \\
\text { improving corporate } \\
\text { governance nationally }\end{array}$ & Level 4: Leadership \\
\hline & $\begin{array}{l}\text { - An internal audit } \\
\text { function is in } \\
\text { place. } \\
\text { - The state audit } \\
\text { institution's work is } \\
\text { clearly defined. } \\
\text { - The SOE prepares } \\
\text { timely annual } \\
\text { financial } \\
\text { statements } \\
\text { according to } \\
\text { domestic financial } \\
\text { reporting } \\
\text { standards. } \\
\text { - Annual financial } \\
\text { statements are } \\
\text { subject to an } \\
\text { independent } \\
\text { external audit. } \\
\text { - The SOE prepares } \\
\text { an annual report. }\end{array}$ & 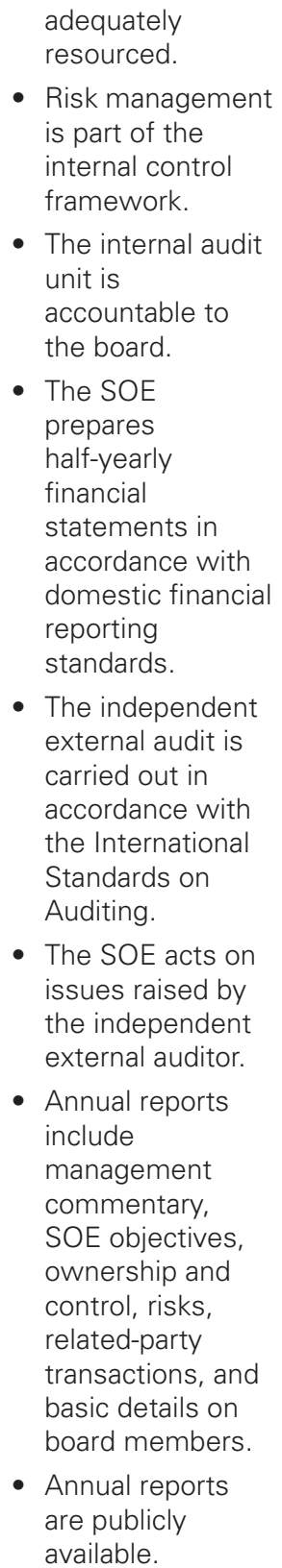 & $\begin{array}{l}\text { public service } \\
\text { objectives. } \\
\text { - Financial statements } \\
\text { are prepared in } \\
\text { accordance with the } \\
\text { International } \\
\text { Financial Reporting } \\
\text { Standards. } \\
\text { - The independent } \\
\text { external audit is } \\
\text { subject to the } \\
\text { oversight of an audit } \\
\text { committee or } \\
\text { equivalent body. } \\
\text { The independent } \\
\text { external auditor's } \\
\text { opinion on the } \\
\text { financial statements } \\
\text { does not contain any } \\
\text { qualification. } \\
\text { - Annual reports } \\
\text { include indirect } \\
\text { ownership and } \\
\text { established for } \\
\text { disclosing related- } \\
\text { party transactions } \\
\text { with other SOEs and } \\
\text { with the government. } \\
\text { goting rights, code } \\
\text { of ethics, key } \\
\text { performance } \\
\text { indicators, } \\
\text { compliance with } \\
\text { corporate } \\
\text { governance code, } \\
\text { and management } \\
\text { and board } \\
\text { remuneration. } \\
\text { The sobligations. } \\
\text { - }\end{array}$ & 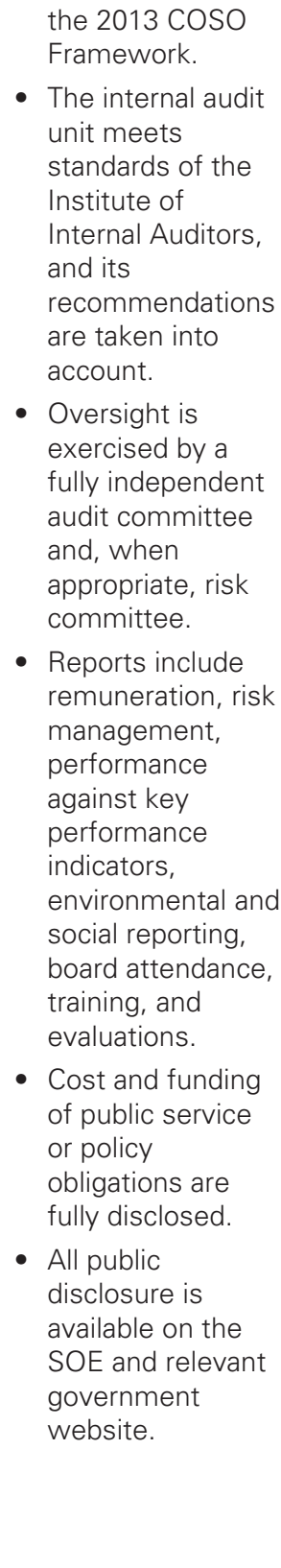 \\
\hline
\end{tabular}




\begin{tabular}{|c|c|c|c|c|}
\hline Attributes & $\begin{array}{l}\text { Level 1: Acceptable } \\
\text { corporate } \\
\text { governance } \\
\text { practices }\end{array}$ & $\begin{array}{l}\text { Level 2: Extra steps } \\
\text { to ensure good } \\
\text { corporate } \\
\text { governance }\end{array}$ & $\begin{array}{l}\text { Level 3: Major } \\
\text { contribution to } \\
\text { improving corporate } \\
\text { governance nationally }\end{array}$ & Level 4: Leadership \\
\hline $\begin{array}{l}\text { D. Treatment of } \\
\text { minority } \\
\text { shareholders }\end{array}$ & $\begin{array}{l}\text { - The company's } \\
\text { legal framework } \\
\text { treats all } \\
\text { shareholders of } \\
\text { the same class } \\
\text { equally with } \\
\text { respect to voting } \\
\text { rights, subscription } \\
\text { rights, and transfer } \\
\text { rights. } \\
\text { - Shareholders } \\
\text { participate in the } \\
\text { shareholders' } \\
\text { meeting and } \\
\text { receive dividends. } \\
\text { Changing the } \\
\text { articles requires } \\
\text { supermajority } \\
\text { approval. }\end{array}$ & $\begin{array}{l}\text { - Shareholders are } \\
\text { provided with } \\
\text { accurate and } \\
\text { timely information } \\
\text { on the number of } \\
\text { shares of all } \\
\text { classes held by } \\
\text { the state and } \\
\text { other major } \\
\text { shareholders. } \\
\text { - The SOE } \\
\text { encourages } \\
\text { minority } \\
\text { shareholders to } \\
\text { participate in the } \\
\text { shareholders' } \\
\text { meeting. } \\
\text { - Minority } \\
\text { shareholders may } \\
\text { nominate board } \\
\text { members. }\end{array}$ & $\begin{array}{l}\text { - Rights of } \\
\text { shareholders are } \\
\text { protected during } \\
\text { new-share issues } \\
\text { and changes of } \\
\text { control, including } \\
\text { privatizations and } \\
\text { renationalization. } \\
\text { - Shareholders are } \\
\text { provided details on } \\
\text { special rights the } \\
\text { state has in the SOE } \\
\text { (golden shares) and } \\
\text { control through } \\
\text { government-linked } \\
\text { entities. } \\
\text { Rules on related- } \\
\text { party transactions } \\
\text { address transactions } \\
\text { with the government } \\
\text { and other SOEs and } \\
\text { require recusal by } \\
\text { interested } \\
\text { shareholders. } \\
\text { holders are treated } \\
\text { equally with respect } \\
\text { to information } \\
\text { disclosure (fair } \\
\text { disclosure). } \\
\text { representation of } \\
\text { minority } \\
\text { shareholders is } \\
\text { provided by } \\
\text { cumulative voting or } \\
\text { similar mechanisms. } \\
\text { Minority } \\
\text { shareholders can ask } \\
\text { questions at the } \\
\text { shareholders' } \\
\text { meeting and } \\
\text { influence its agenda. } \\
\text { - }\end{array}$ & $\begin{array}{l}\text { - The state has no } \\
\text { special rights in } \\
\text { the company } \\
\text { (golden shares) } \\
\text { beyond its } \\
\text { ownership. } \\
\text { - Supermajority } \\
\text { approval is } \\
\text { required for large, } \\
\text { extraordinary } \\
\text { transactions. } \\
\text { - The SOE's history } \\
\text { of equitable } \\
\text { treatment of } \\
\text { shareholders } \\
\text { evidences } \\
\text { consistent } \\
\text { conformity with } \\
\text { international } \\
\text { market } \\
\text { expectations. }\end{array}$ \\
\hline
\end{tabular}




\begin{tabular}{|c|c|c|c|c|}
\hline Attributes & $\begin{array}{l}\text { Level 1: Acceptable } \\
\text { corporate } \\
\text { governance } \\
\text { practices }\end{array}$ & $\begin{array}{l}\text { Level 2: Extra steps } \\
\text { to ensure good } \\
\text { corporate } \\
\text { governance }\end{array}$ & $\begin{array}{l}\text { Level 3: Major } \\
\text { contribution to } \\
\text { improving corporate } \\
\text { governance nationally }\end{array}$ & Level 4: Leadership \\
\hline $\begin{array}{l}\text { E. Commitment } \\
\text { to corporate } \\
\text { governance }\end{array}$ & $\begin{array}{l}\text { - The SOE has } \\
\text { stated its intention } \\
\text { to improve its } \\
\text { corporate } \\
\text { governance } \\
\text { practices. } \\
\text { - The SOE has a } \\
\text { legal status } \\
\text { distinct from the } \\
\text { government. }\end{array}$ & $\begin{array}{l}\text { - The SOE uses } \\
\text { documented } \\
\text { policies, including } \\
\text { those on } \\
\text { governance and } \\
\text { ethics, and has a } \\
\text { program to } \\
\text { improve } \\
\text { governance. } \\
\text { - The SOE is } \\
\text { corporatized. } \\
\text { - The SOE has } \\
\text { access to outside } \\
\text { finance. } \\
\text { - The SOE's public } \\
\text { service and policy } \\
\text { obligations are } \\
\text { clearly defined. }\end{array}$ & $\begin{array}{l}\text { - The SOE discloses } \\
\text { its compliance with } \\
\text { a national code of } \\
\text { governance. } \\
\text { - The SOE is } \\
\text { incorporated under } \\
\text { company law. } \\
\text { - The financing and } \\
\text { nature of the SOE's } \\
\text { public service and } \\
\text { policy obligations are } \\
\text { transparent. }\end{array}$ & $\begin{array}{l}\text { - The SOE has } \\
\text { adopted corporate } \\
\text { governance } \\
\text { practices that are } \\
\text { consistent with } \\
\text { international good } \\
\text { practice. } \\
\text { - The SOE has } \\
\text { issued securities } \\
\text { and meets listing } \\
\text { requirements. } \\
\text { - The SOE's public } \\
\text { service and policy } \\
\text { obligations are } \\
\text { fully compatible } \\
\text { with its } \\
\text { commercial } \\
\text { orientation. }\end{array}$ \\
\hline
\end{tabular}

Note: Adapted from the Corporate Governance Development Framework of the International Finance Corporation. 


\section{Company-Level Tools: Information Request List and Interview Guide}

\section{Financial Discipline}

Company objectives. What are the company's policy and commercial objectives? How were these set? Are they publicly disclosed? How are the policy activities funded? How are the costs of the policy activities valued and disclosed in the financial statements?

Direct and indirect benefits. What benefits (for example, dividend flows, concessionary pricing, or other financing), if any, does the state ${ }^{1}$ or its nominees receive from the company? Which state-related entities or individuals receive these benefits? What benefits (for example, regulatory exemptions, tax relief, subsidies, guarantees, or concessionary pricing or financing), if any, does the company receive arising from its relationship with the state?

Note: Adapted from the Corporate Governance Development Framework of the International Finance Corporation. 
How are these benefits (to and from the state) valued and disclosed in the financial statements?

Funding costs and capital structure. How does the capital structure of the company (that is, the weighted cost of capital, cost of equity and debt, debt-to-equity ratios, or interest coverage) compare to industry benchmarks? What are the dividend payout targets, and how are they set? Has the company issued bonds, and are these objectively rated? Does the company receive any funding from state-owned banks? How do the terms of the company's bank loans (from state and from nonstate banks) compare with facilities extended to nonstate enterprises?

\section{Board of Directors}

Establishment of a board of directors. What has been the company's historical experience with its board of directors? When was the board established? How often does it meet? Is an agenda prepared and distributed in advance of board meetings? Are minutes prepared and approved after board meetings?

Board policies. Please provide English translations of any policies or by-laws relating to the practices of the board of directors.

Current board and senior management. Please provide a list of the current members of the board, as well as senior management, with summary CVs indicating, at a minimum, their affiliations with the company, management, controlling shareholders, and relevant government or political entities and other companies for which such persons serve as board members. Please detail the compensation directors receive for their services.

Composition of the board. As a practical matter, how is the composition of the board of directors determined? How are the chairperson, chief executive officer (CEO), and senior managers appointed? Are there any shareholder agreements or provisions of the company's charter that specify which shareholders appoint directors? Are there any informal understandings? Are there specific provisions for board or senior management positions for representatives of specific constituencies such as political parties, workers, civil society, ethnic groups, or geographical regions?

"Independent" board members. How, if at all, does the company define independent with respect to board members? Who are the independent members of the board of directors (independent of management and dominant shareholders), and how were they selected? Are there any board members or senior managers who are political appointees or who could be perceived (by informed media or the public) as political appointees? Are 
there any board members or senior managers who are or could be perceived as related parties to elected officials or their political appointees?

Skill mix. What sorts of business and other experience are represented on the board? What efforts are made to ensure an appropriate mix of skills and experience among board members?

Functioning of the board. Does the board serve the classic functions of a board (providing guidance to and monitoring the performance of the senior management for the benefit of all shareholders), or is the board's primary function to act as a meeting of shareholders? Does the state impose any specific restrictions on the board's authority? Does the board report to any specific state entity or individual? Does the state or political directorate maintain any lines of communication (except for shareholders' meetings and public disclosures) with the board, senior managers, or others in the company?

The state, the board, and the management team. Are senior managers members of the board, or do they, in any case, routinely attend board meetings? If so, does the board regularly hold "executive sessions" without the presence of management? What is understood as the role of the state, the board, and the management, particularly with respect to the following:

- Setting the company's strategy and vision

- Selecting the CEO and senior management

- Overseeing internal controls, external audit, and preparation of financial statements

- Approving major capital expenditures and large-value transactions

- Overseeing human resources functions (including hiring, compensation, and performance management) and dividend policy

Audit and other standing committees. Does the board of directors have an audit committee or other standing committees, such as governance, procurement, finance, nomination, remuneration, or conflicts of interest? How are these committees established, who sits on them, and how do they function?

Conflicts of interest and related-party transactions. Does the company have any special rules and procedures for board review of transactions that involve conflicts of interest and related parties? Does the company provide any goods, services, or financing on any concessionary terms to any state or quasi-state entity or to any third parties at the request of the state? How are these transactions disclosed? Please provide a summary table of relatedparty transactions reviewed by the board or committees of the board over the past three years. 
Board evaluation. Does the board conduct self-evaluations or other reviews of its effectiveness? How are such reviews conducted and with whom are the results shared?

Corporate secretary. Does the company have a corporate secretary whose responsibilities include organizing and facilitating the way in which the board of directors functions? If not, who organizes board meetings?

Inspection committee. Do national company laws require the company to have some form of inspection committee, such as an audit or revision commission? If so, describe how it functions and what the company's historical experience with this committee has been. Please provide a list of the current members of the inspection committee with summary CVs indicating, at a minimum, their affiliations with the company, management, and controlling shareholders. If the company has both an inspection committee and an audit committee of the board of directors, how are the oversight responsibilities divided up between the two? To whom does the inspection commission report?

\section{Transparency, Disclosure, and Controls}

Internal control design. Please describe how the company's internal controls (for operations and financial activities and for the company's highly automated systems) are designed and maintained. Are the existing internal controls (IC) documented and the documentation reviewed periodically? Do the board and management appropriately consider control issues when planning new strategies, activities, and products? Does the external auditor report on the adequacy of the company's system of internal controls? Are there areas of IC deficiency reported repeatedly by the external auditors?

Internal control assurance. What is the role of the audit committee? Does the board periodically review the policies and procedures designed to ensure that proper internal controls are instituted and maintained? Does the board receive assurance from the management that appropriate controls over information processing, physical assets, and segregation of duties are appropriate to the organization's size and risks? How does the board receive assurance that adequate internal controls are in place over any outsources financial functions? Does the board receive assurance from the management that the outside firm is in compliance with all relevant laws, regulations, and company policy? Does the board review the procedures for communicating the importance of internal controls and appropriate conduct to the entire staff? 
State, internal, and external auditors. Are the company's internal audits undertaken by the company's own internal unit, by a state auditor, or by both? Please describe the role, structure, competencies, and reporting of the company's internal audit function, whether it is the company's own internal audit unit or state auditors. If the company has both, please describe their respective roles. Are external audits of the company's financial statement undertaken by independent external auditors, by a state auditor, or by both? If both, what are their specific roles?

Authority of the internal auditors. How often does the internal auditor (IA) chief meet privately with the board and with the audit committee? What are the procedures for hiring and dismissing the chief internal auditor? Does the IA unit have full access to records, property, and personnel relevant to its audit? Is the IA unit responsible for testing the company's program for compliance with laws, regulations, and company policy? If the function is captive, is the chief internal auditor part of the firm's senior management, and does the IA unit have an audit charter that is approved by the audit committee or board?

Objectivity of the internal auditors. Do the company's internal auditors have operating, state, or political assignments in addition to their audit roles? Is each internal auditor independent of the activity that he or she audits? Are the internal auditors rotated periodically to different areas of audit responsibility? How long are they assigned to a single unit, department, or subsidiary? How do they report any conflicts of interest? Does the audit committee review these? Are any of the politically appointed internal auditors related to or otherwise connected with major shareholders, directors, or other senior managers?

Responsibilities of the internal auditors. Are the internal auditors' work plans reviewed by the audit committee or the board? Are they reviewed by the $\mathrm{CEO}$, chief financial officer (CFO), and other senior executives? Are work plans set by law, legislation, or the state? Are the work plans and programs consistent with any relevant local or international internal control frameworks and internal auditing standards? Does the internal audit unit report separately on deficiencies, significant deficiencies, and material weaknesses? Does the board monitor management's response to the deficiencies and weaknesses identified by the internal audit? Does the company undertake self-assessments of internal controls? How long are internal audit working papers maintained?

Risk management. Who is responsible for developing the risk management system? How are the risks identified and the risk appetite set? Does the board periodically review the risk management systems? What is the role of the internal audit unit in the management of risk? How often is management 
of risks compared to targets approved by the board? How is this reported to the board? Do the board and management appropriately assess risks when planning new strategies, activities, and products?

Capabilities of a company's internal audit unit. Please describe the (operational and financial) competencies and skills of the internal audit staff. Does the audit committee review the adequacy of training and expertise provided for the IA unit? Does the audit committee review the resources available to the IA unit? What has been the turnover in the IA unit over the past three years? If the firm's operations are highly automated, does the IA function have adequate capabilities (skills and frameworks) to monitor the controls and risks in automated environments? Has the IA unit undergone a peer review exercise within the past five years?

Outsourcing of the internal audit function. Please respond to the following questions if your internal audit function is outsourced to an entity other than state auditors. What is the company's policy on the selection of IA service providers? Was the appointment of the provider reviewed by the audit committee or state? Are the outside service provider and its staff appropriately licensed? Which of the firm's executives is responsible for the liaison with and evaluation of the IA service provider's work? Does the provider have any links to the current external auditor? Is the provider independent of organizational officers, board members, and their families? Does the provider have other substantive contracts with the firm, and how are they monitored?

External audit and external auditors. What is the company's policy on the selection of external auditors? Who, formally and in practice, selects the external auditors and decides on fees, and to whom are they responsible (the shareholders' meeting, the state, the board, the audit committee, the controlling shareholder, senior management)? Is it the policy to rotate the external auditors? Are the audit partners rotated? What other services does the external auditor perform for the company and its affiliates (controllers, sister companies, subsidiaries)? Is the auditor a recognized audit firm? Are the audits conducted in accordance with international standards of auditing? Who has access to the working papers and management letters ("deficiency letters" or "recommendation letters") prepared by the external auditors?

Coordination between external and internal auditors. What is the procedure and calendar over the course of the fiscal year for interaction between the external and internal auditors? Does the IA unit monitor or follow up on the correction of weaknesses, irregularities, and exceptions identified by regulators and by the external auditors? How is the audit committee informed of the clearances and corrections of identified weaknesses, 
violations, or exceptions? If there is no IA function, how are the deficiencies identified by the external auditors and regulators systematically addressed? Does the audit committee meet jointly and separately with the internal and external auditors?

Reporting and internal controls. Do the officers signing the annual financial statements (usually the CFO and CEO) accept, in writing, their corporate responsibility for establishing and maintaining the internal controls over financial reporting? What systems have been put in place for the signing officers to evaluate the IC systems? Has the CFO or CEO reported to the board, audit committee, and the external auditors all material IC weaknesses that may have impaired the reliability of the financial reports? Is the CFO or CEO required to disclose any fraud to the external auditors, the board, and the audit committee?

Compliance program. Please describe the company's compliance program or procedures, including training of employees, auditing and monitoring systems, company "hotline" for reporting violations, guidance on conflicts of interest, and appropriate sanctions and disciplinary action for violations. What information does the company provide to the shareholders on its compliance program and its results?

Revision committee or fiscal council. If you have either, please describe its structure, role, and function. How is the revision committee's or the fiscal council's role different from that of the audit committee?

Information dissemination. Please summarize the company's policies with respect to preparation and dissemination of financial and nonfinancial information about the company, including a calendar of information disclosed on a regular basis to the public, any relevant regulator, and any exchanges on which the company's securities are traded. To what extent do the company's policies in this respect go beyond the minimum requirements of the securities and other regulators and the exchanges? Who in the company is responsible for drafting, reviewing, and approving the company's periodic disclosures? Does the company make disclosures available on the Internet in a timely fashion?

Financial statements. Does the company produce financial statements in accordance with the International Financial Reporting Standards or the U.S. Generally Accepted Accounting Practices? Does the company use any alternative government accounting methods or reports? Are these reports consolidated or aggregated with other state entities? Have the financial statements been restated in the past three years? Why? Does the company publish quarterly reports, including segment reporting?

Review of the financial statements. Is the audit committee briefed on the major off-balance-sheet items and their potential impact if taken into 
account on the financial statements? Does the audit committee review the major accounting adjustments made by the external auditors? Does the audit committee review the accounting adjustments requested by the external auditors but rejected by the management? Is the audit committee made aware of any changes made to accounting policies and their impact on the current financial statements? Does the audit committee review major accounting estimates and major assumptions made in the financial statements with the external auditors? Is the audit committee briefed on planned changes to accounting and regulatory rules that may affect the financial statements in the next two years?

Shareholders' agreements. Are shareholders' agreements with or among the controlling shareholders disclosed to all shareholders? Are shareholders' agreements registered with the applicable regulator?

Disclosure of major transactions and material events. What is the procedure for drafting, reviewing. and approving disclosure of major transactions and other material events? How has the company complied with regulatory and exchange rules with regard to disclosure of major transactions, including mergers and acquisitions? Is the bidding for major procurement contracts made by competitive processes or public auction? How is the basis of the award disclosed? Please provide a summary of any major transactions in the past three years that have been subject to special review by the regulator, supreme audit body, state, or the exchange.

Employee stock ownership and stock options. If listed, please provide descriptions (including approval processes, disclosure, and accounting treatment) of any employee stock ownership or stock option schemes in place at the company in the course of the past five years. Provide figures on amounts and value of securities of the company distributed to executives and employees (and options exercised) pursuant to such schemes.

Regulatory and self-regulatory review. What has been the company's experience with review of its periodic disclosure by any relevant regulator and the exchange? Has the regulator or the exchange ever required the company to provide additional information or clarification in the annual report or other disclosure? Has the company ever been sanctioned or censured by any relevant regulator or exchange for any failure or delay in disclosing required information to the public?

Fair disclosure and responses to information requests. How does the company ensure equal treatment of all shareholders and the market in the release of financial and nonfinancial information, including company strategy? What are the company's policies on responding to individual requests for information from civil society, investors, market participants, and journalists? Who is responsible for carrying out the policy? 
Meetings with securities analysts. Are periodic meetings with securities analysts held? Who in the company participates in such meetings?

\section{Treatment of Minority Shareholders}

Ultimate beneficial ownership. What disclosures are made to the public on the ultimate beneficial ownership of shares in the company by controlling shareholders and management?

Shareholders' meetings. Who in the company is responsible for calling, organizing, and reporting the results of annual and extraordinary shareholders' meetings? What is the role of the corporate secretary with respect to shareholders' meetings? Please provide a timetable for the annual general meeting of shareholders. How much notice is required? When is the agenda provided? Under what circumstances can shareholders add items to the agenda? Who is responsible for registering participants and counting ballots at the shareholders' meetings? Have there ever been any lawsuits or state actions relating to the functioning or propriety of decisions taken at a shareholders' meeting?

Attendance and results of shareholders' meetings. Please provide a summary of the attendance and results of all shareholders' meetings (annual and extraordinary) for the past three years, including number of shares represented, number of shareholders represented, agenda items, and record of votes. Are shareholders' meetings open to the public?

Related-party transactions. Please provide a table of related-party transactions and other operations of the company that required shareholder approval over the past three years. How is information on related-party transactions (including those that did not require shareholder approval) usually disclosed?

Changes of control. What would be the treatment of minority shareholders in the event of a change of control of the company? Are there tag-along rights for minority shareholders that require the new controller to make an offer to purchase their shares at the same price and conditions? Is there any other requirement that the new controller make a tender offer concurrent with or following the change of control of the company?

Minority shareholder nomination of board members. What mechanisms, if any, permit minority shareholders to nominate members of the board (cumulative voting, block voting, and the like)? Have such rights been exercised in the past?

Other minority shareholder rights. Are there any types of transaction or other events that require some sort of special voting procedures (such as 
supermajority approval by the shareholders or majority vote of minority shareholders)? What mechanisms, if any, exist in the company's charter or policies that permit minority shareholders to take action against the company, its management, or controllers to prevent actions that might be unfairly prejudicial to the minority? Have such actions ever been taken?

History of shareholder relations. What is the company's history of disputes with shareholders? What types of disputes have arisen? Has the regulator or the exchange ever conducted any investigation into the company's treatment of shareholders? How have shareholder disputes been resolved?

Differentiated classes of equity and quasi-equity securities. Please outline the principal terms of and differences in voting rights and cash flow rights between the company's various classes of equity and quasi-equity securities.

\section{Commitment to Corporate Governance}

State ownership. Which entity, agency, or unit is the formal state shareholder, and what is its percentage ownership of the company? Does this entity, agency, or unit exercise the shares' voting rights? Are there other shareholders that are state-related or -owned entities? What is the combined percentage ownership of the state and all other quasi-state shareholders? To what extent should all or some of the state shareholders be considered a single voting bloc?

Ownership and control. Is the degree of state control of the company proportionate to (or greater than or less than) the state's percentage shareholding? Does the state control the company through ownership of a majority (or at least a plurality) of shares or through some other mechanism, such as through the party committee, through "golden shares," by law, or through links with other state-related shareholders? Please provide details (in English) of any shareholders' agreements, links, or other informal arrangements among all or some shareholders.

Management and worker share ownership. What percentage of shares, if any, is owned by the management or workers of the company? Do the workers control their own shareholding, or is it controlled by the management? To what extent should the share ownership of the management and workers be considered part of the state-related shareholding bloc? If not, how are the workers' shares voted? Are the workers considered or compensated (including wages and pensions) as state employees?

Corporate structure. Please provide a chart setting out the important shareholdings, holding companies, affiliates, and subsidiaries of the company, indicating ultimate beneficial ownership and percentages held by each. 
Governance structure. Please provide a chart setting out the governance structure of the company, indicating the principal organs of the company's governance and to whom each reports (including the state and its affiliates, the shareholders' assembly, the board of directors and any board committees, senior management, internal audit, external audit, and principal management units).

Major transactions and material events. Please provide a timeline of major transactions and material events for the past five years (in particular, corporate acquisitions, mergers, restructurings, and sales or purchases of major assets, etc.). What disclosures of material events were made to the public and markets in each case?

Organic documents. Please provide the company's charter and other organic documents.

Policies relating to corporate governance. What written policies, codes, or manuals have been produced that set out the company's approach to governance; the respective roles, responsibilities, and composition of the board; disclosure and transparency practices; and treatment of minority shareholders?

Corporate events calendar. Do the senior management and the board approve an annual calendar of corporate events, including the shareholders' meeting and board meetings?

Company corporate governance code. Does the company have a corporate governance code (or "policy" or "guidelines") that outlines the governance practices of the company and, in particular, the role of the board? What are the company's procedures for monitoring its compliance with the corporate governance code?

Country corporate governance code. Are the board and the senior management familiar with the voluntary code of corporate governance for the country (if such a code exists)? To what extent does the company comply with the provisions of this code?

Code of ethics. Does the company have a code of ethics? Which employees are subject to it? How are the company's ethical precepts communicated to employees? How is compliance overseen and enforced?

Compliance responsibility. Who in the company is primarily responsible for ensuring that the company complies with the law, its charter, and policies on corporate governance (that is, role of the board, transparency and disclosure, and treatment of shareholders) and with the code of ethics? Does the company disclose to its shareholders on a periodic basis the extent to which it is complying with its rules on corporate governance?

Succession planning. What has been the history of succession of the chief executive officer? What is the role of the state in the company's succession 
planning? Does the company have a written policy concerning succession planning? How much longer does the current chief executive intend to remain in this position?

Annual report. Please provide a translation of any discussion of the company's corporate governance included in its latest annual report, if any. Who in the company drafted, reviewed, and approved such disclosure? What models or examples did the company use in drafting this disclosure?

\section{Note}

1. State in the document includes all levels of the political directorate-local, municipal, federal, regional, and national. 
APPENDIX G

\section{Company Level Tools: Sample Company-Level Corporate Governance Improvement Program}




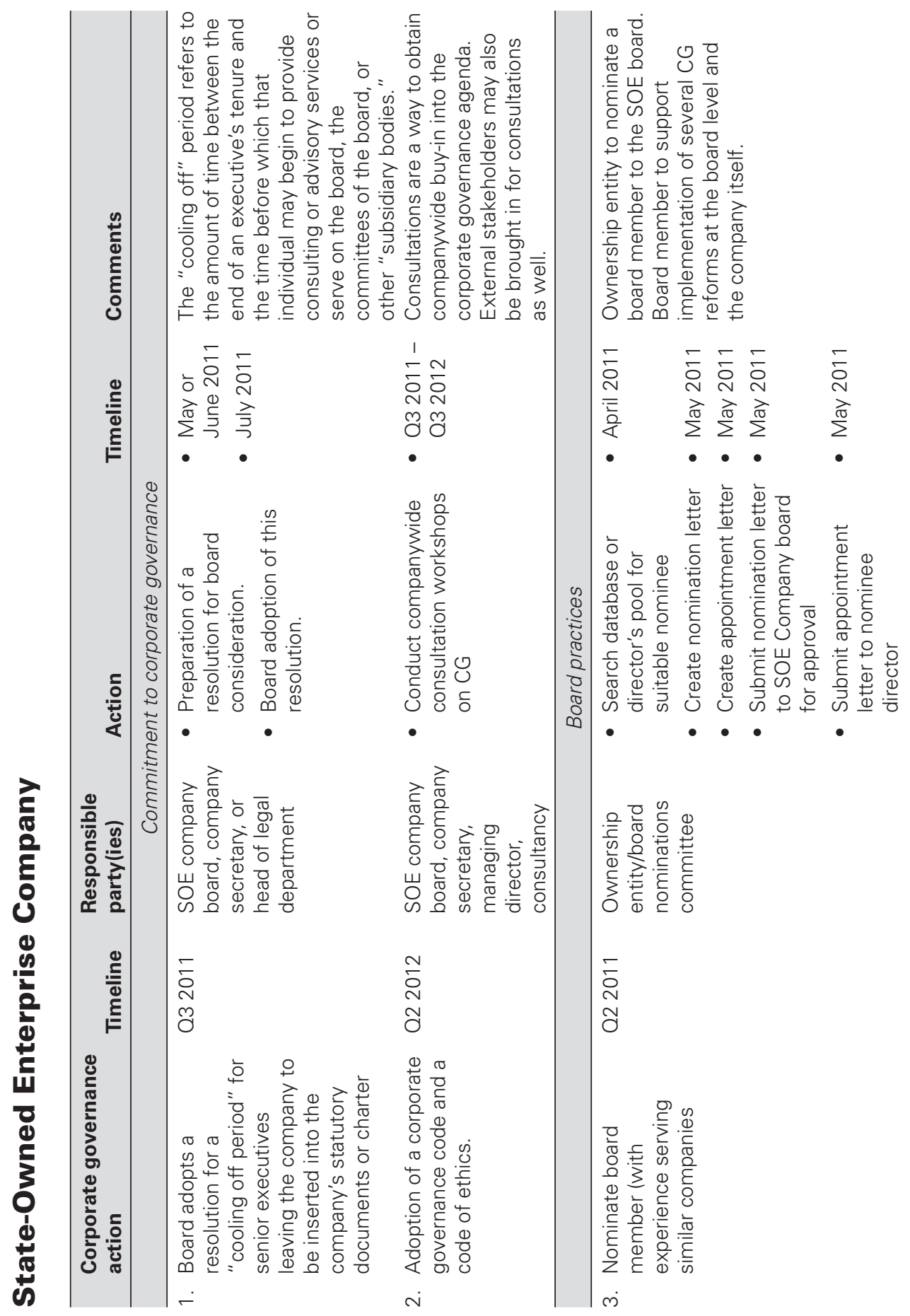




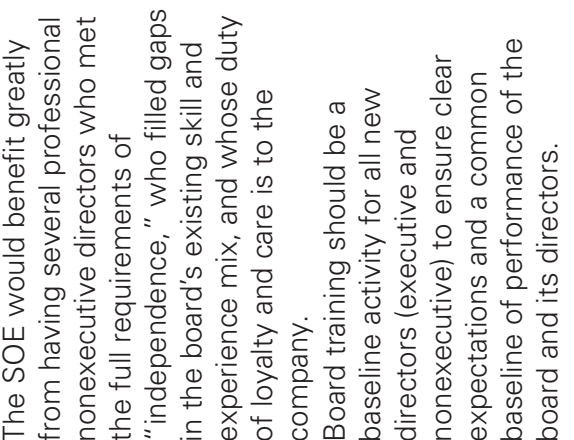
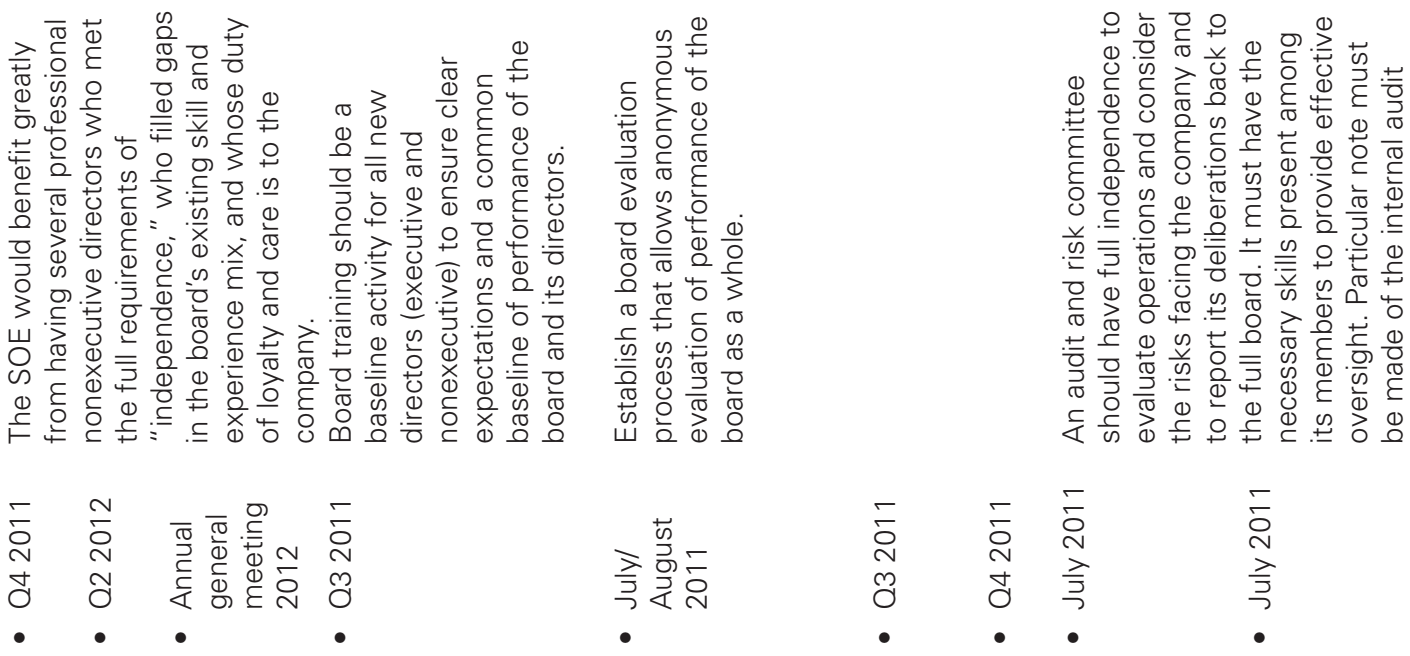

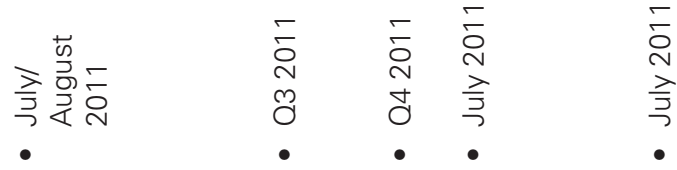
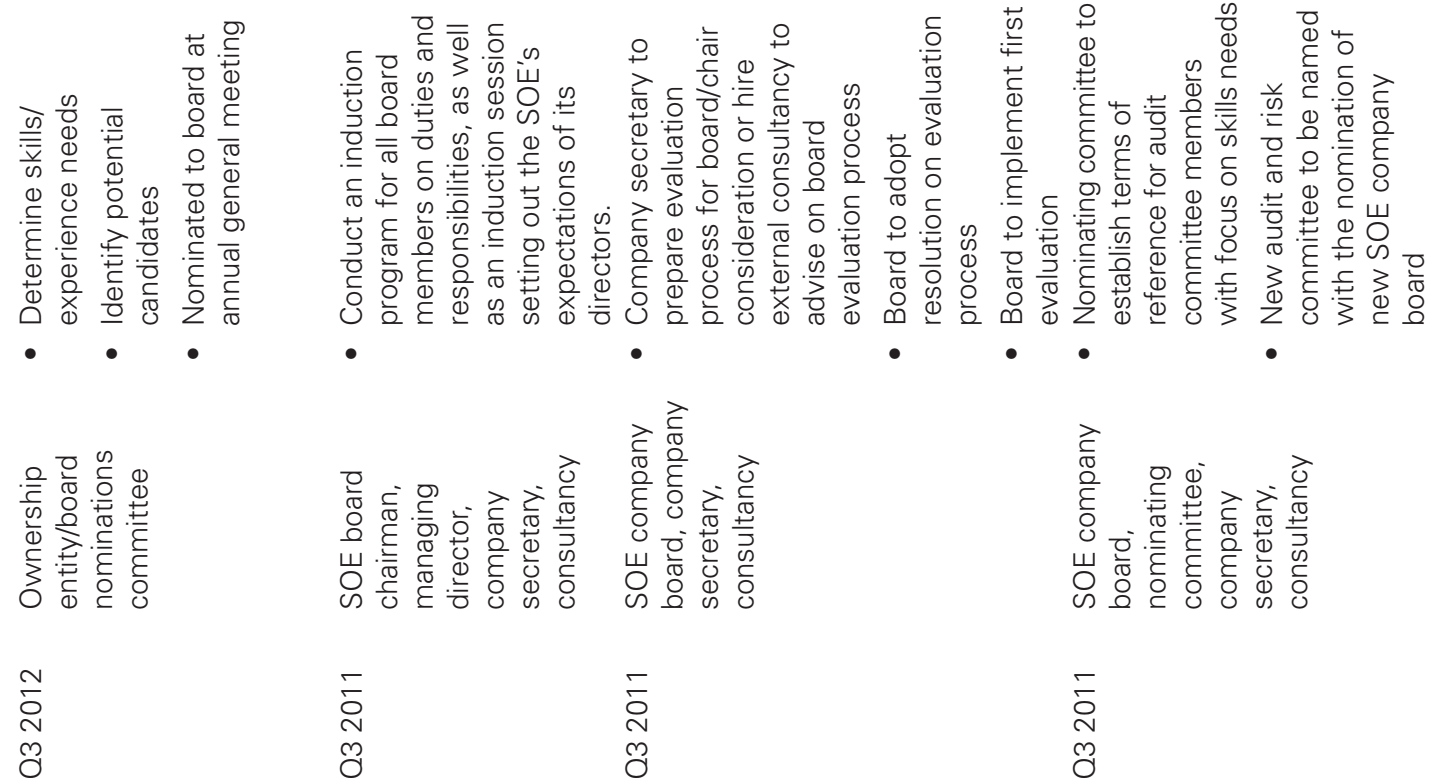

$\check{\sigma}$
ฮิ
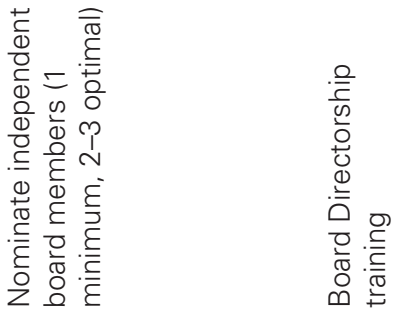

든
$\frac{0}{0}$
$\frac{0}{3}$
$\frac{1}{0}$
$\frac{1}{0}$
$\frac{0}{0}$
$\frac{0}{0}$
0
0

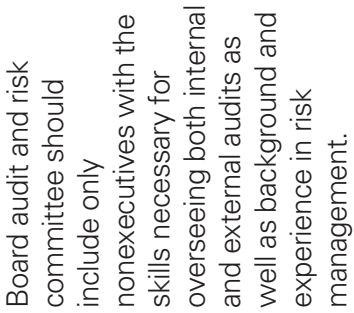

$\checkmark$

เ

$0^{\circ}$

N 


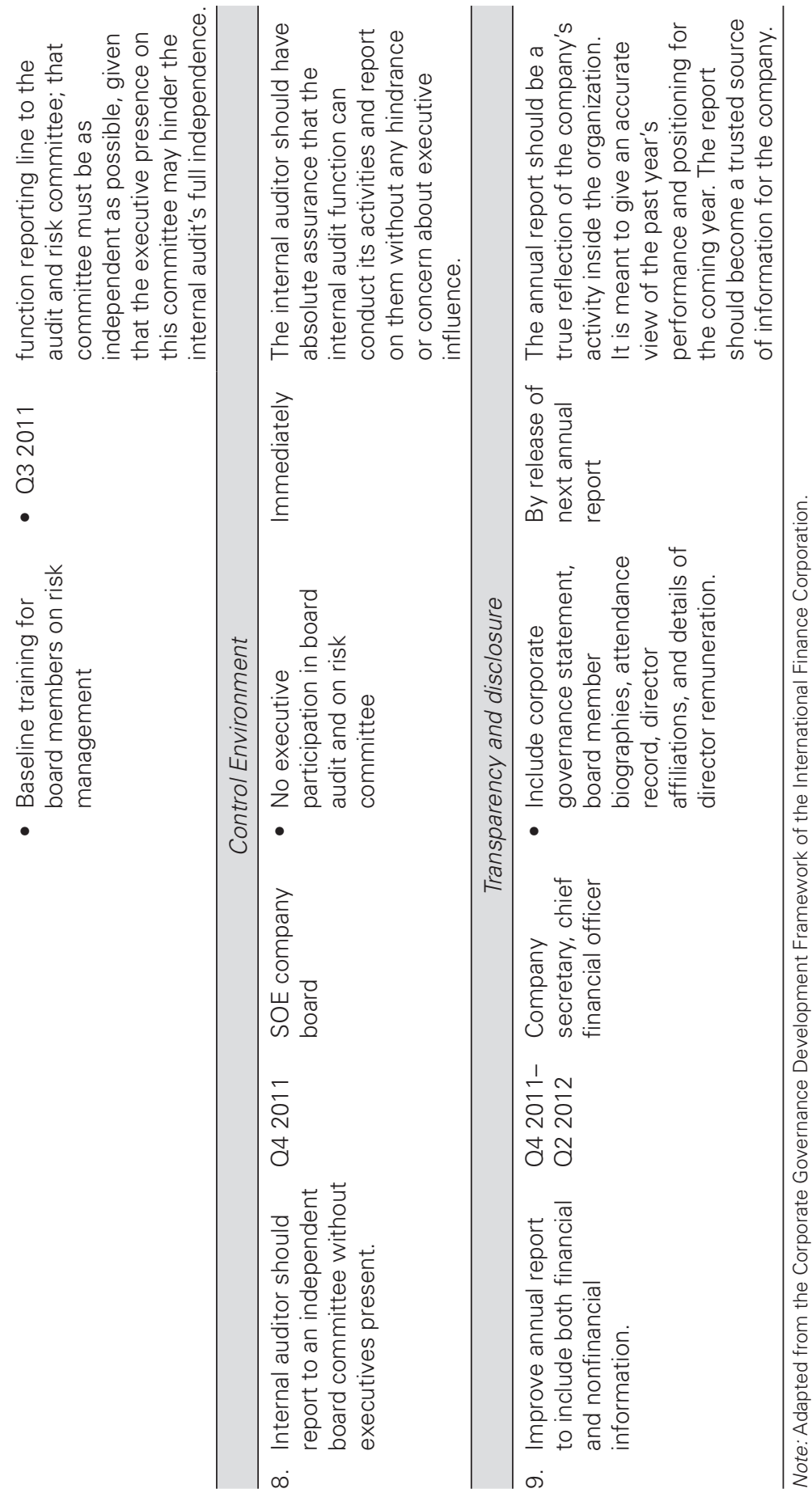




\section{ECO-AUDIT \\ Environmental Benefits Statement}

The World Bank is committed to preserving endangered forests and natural resources. Corporate Governance of State-Owned Enterprises: A Toolkit was printed on recycled paper with 100 percent postconsumer fiber in accordance with the recommended standards for paper usage set by the Green Press Initiative, a nonprofit program supporting publishers in using fiber that is not sourced from endangered forests. For more information, visit www .greenpressinitiative.org.
Saved:

- 29 trees

- 13 million British thermal units of total energy

- 2,501 pounds of net greenhouse gases ( $\mathrm{CO}_{2}$ equivalent) -13,563 gallons of waste water

- 907 pounds of solid waste 

State-owned enterprises (SOEs) are still significant players in critical economic sectors such as infrastructure, finance, natural resources, and manufacturing. They are under increasing pressure to improve their performance. These pressures come from various sources, including the need to enhance their competitiveness and that of the economy as a whole, especially where SOEs are major players; to provide essential infrastructure, financial, and other services to businesses and consumers more efficiently and cost effectively; to access alternative sources of finance through the capital markets while reducing their fiscal burden and fiscal risk; and to enhance the transparency and accountability of the use of scarce public funds. Improved performance of financial SOEs is also essential for broader financial sector development and for ensuring the soundness and stability of the financial system. A long history of SOE reform shows that the key to better SOE performance is improved governance.

The aim of the Corporate Governance of State-Owned Enterprises: A Toolkit is to harness reform experiences and the growing body of knowledge to help policy makers and practitioners improve the corporate governance of SOEs. The toolkit provides an overall framework and practical solutions for improving SOE governance for the benefit of all stakeholders: governments, managers, employees, consumers, and citizens. It focuses on commercial enterprises in which the government has significant control through full, majority, or significant minority ownership. It includes SOEs in a range of sectors-manufacturing and services, utilities, banks and other financial institutions, and natural resources. The toolkit does not cover noncommercial SOEs fulfilling special public policy purposes (whether or not in a corporate form), although the frameworks and tools may still be relevant for such entities. 